\title{
LOGÍSTICA APLICADA À COLHEITA MECANIZADA DE CEREAIS
}

\author{
Saulo Salaber Souza e Silva
}

Dissertação apresentada à Escola Superior de Agricultura "Luiz de Queiroz", Universidade de São Paulo, para obtenção do título de Mestre em Agronomia, Área de Concentração: Máquinas Agrícolas.

P I R A C I C A B A

Estado de São Paulo - Brasil

Maio - 2004 


\title{
LOGÍSTICA APLICADA À COLHEITA MECANIZADA DE CEREAIS
}

\author{
SAUlo SALABER Souza E SILVA \\ Engenheiro Agrícola
}

Orientador: Prof. Dr. MARCOS MILAN

\begin{abstract}
Dissertação apresentada à Escola Superior de Agricultura "Luiz de Queiroz", Universidade de São Paulo, para obtenção do título de Mestre em Agronomia, Área de Concentração: Máquinas Agrícolas.
\end{abstract}

P I R A C I C A B A

Estado de São Paulo - Brasil

Maio - 2004 


\section{Dados Internacionais de Catalogação na Publicação (CIP) DIVISÃO DE BIBLIOTECA E DOCUMENTAÇÃO - ESALQ/USP}

Silva, Saulo Salaber Souza e

Logística aplicada à colheita mecanizada de cereais / Saulo Salaber Souza e Silva. - - Piracicaba, 2004.

148 p. : il.

Dissertação (mestrado) - - Escola Superior de Agricultura Luiz de Queiroz, 2004.

Bibliografia.

1. Cereais 2. Colhedoras 3. Colheita mecânica 4. Logística 5. Máquinas agrícolas 6. SisColhe (Sistema de Computador) I. Título

CDD 633.1

"Permitida a cópia total ou parcial deste documento, desde que citada a fonte - O autor" 
Ao meu pai Moacir e à minha mãe Graça, por tudo o que fizeram e até hoje fazem por mim, pelo amor e pelo carinho, por serem a razão de eu ser a pessoa que sou hoje, minha fonte de inspiração e exemplo.

Aos meus irmãos Hernani e Lílian, por todo o amor, carinho e bem querer.

E a todas as pessoas especiais que fazem parte da minha história, 


\section{AGRADECIMENTOS}

À Universidade Federal de Lavras, instituição que levarei comigo para sempre, sobretudo por minha formação profissional em Engenharia Agrícola, profissão essa da qual muito me orgulho, e por minha formação como pessoa. Obrigado pelos anos de graduação, pelas amizades construídas e pelo inicio de minha carreira. Serei eternamente grato.

À Escola Superior de Agricultura "Luiz de Queiroz" e ao seu Programa de PósGraduação em Máquinas Agrícolas, por terem me aceito como aluno e pelos votos de confiança depositados. Agradeço muito a oportunidade de ter estudado em uma escola de tamanha tradição, história e contribuição para a agricultura brasileira.

Ao Prof. Marcos Milan, por sua orientação, amizade, companheirismo, apoio, confiança e incentivo. Obrigado por tudo Professor. Obrigado por sua atenção, por suas palavras sempre amigas e pelo enriquecimento profissional que vivenciei durante o curso.

Ao pesquisador e amigo Afonso Peche Filho, por ter me despertado a decisão de realizar o curso de pós-graduação, pela co-orientação e acima de tudo pela sabedoria, pelo conhecimento e pela amizade comigo compartilhados em todos os momentos. Aos amigos de Lavras Ely e Cristina Tourino. Sem vocês talvez eu não tivesse iniciado a pós na época e na área em que eu iniciei. Vocês foram marcantes nessa história.

Aos Profs. membros dos exames de qualificação e de defesa José Paulo Molin, Antônio José da Silva Maciel e Kleber Pereira Lanças, pela prontidão, disponibilidade e atenção sempre demonstrados. Muito obrigado!

À Fundação de Amparo à Pesquisa do Estado de São Paulo pela confiança no projeto, pela bolsa de estudos concedida e por ter proporcionado as condições necessárias ao desenvolvimento do trabalho ao longo de todo esse período.

Às Empresas Agropecuárias Lúcio Miranda, por terem acreditado no projeto. 
Muito obrigado Allison, Claudinei, Gilmar, Mario e todos os outros funcionários que lá eu convivi. Um agradecimento especial ao Sr. Lúcio Miranda. Foi uma satisfação ter conhecido uma pessoa de tamanho carisma e visão empresarial.

Aos companheiros de graduação e eternos amigos Barba, Santista, Japa, Murilo, Dião, Leyser, Teco, Du, Didi, Tadeu, Kelte, Tibúrcio e Ganso. Valeu moçada! Valeu pelos cinco anos juntos, por toda a amizade, por todos os momentos vividos e por todo o aprendizado que tive com vocês. Jamais me esquecerei de nenhum de vocês.

Às queridas amigas de faculdade Sarita, Tatá e Ari. Obrigado meninas por todos os momentos juntos e pelo carinho que vocês sempre demonstraram comigo. Quando penso nos bons tempos de faculdade, sempre tenho vocês em minhas lembranças! Aos grandes amigos de Pira, que tenho como irmãos, Simão, Mauricio e Touchê por toda a amizade e por toda a confiança construída. Tenho certeza que irão durar para sempre.

À todos os amigos dos tempos de Pira, por tudo de bom e por todas as alegrias que vivi nesse período. Obrigado Maurão, Gaúcho e Tobias, à todos os amigos de república, Percy, Mauro, Nilton, Franco, René e Edgar e aos amigos do grupo Chama Eu, Rogério, Flavião e Sandal. Aos amigos Satã, Pedrita, Rruço e Nervo por toda a amizade e companheirismo. Peço perdão a todos os amigos não mencionados. Sei que são muitos, mas quero que saibam que tenho todos vocês sempre em minhas lembranças.

A todos os amigos da pós, em especial MT, Rafael, Rui, Rodrigo, Manu Pinça e Slot pelas boas horas de aula compartilhadas. Um agradecimento especial à querida amiga Antartik por toda a amizade, carinho e bem querer sempre demonstrados.

À família Suguisawa: Sr. Jorge, Dna. Mercedes, Danilo, Murilo e Liliane, por todo o carinho que sempre tiveram comigo. Um agradecimento especial ao grande amigo e irmão desde a faculdade Murilo, por todo o companheirismo na idealização do projeto e no desenvolvimento das atividades. Valeu meu irmão.

Aos amigos Jarbas H. Miranda, Luciano Taquia e Áureo por todo o auxilio no desenvolvimento do modelo. Com vocês, me lembrei que, nessa vida, não se faz nada sozinho. Não teria concluído o modelo sem vocês. Muito obrigado.

À bibliotecária Eliana pela atenção, disponibilidade e rapidez na indicação das necessárias correções do documento. 
Aos amigos gaúchos Paulo, Luciane Kern e Luciane Scheneider que, apesar de termos nos conhecido apenas nos meus últimos momentos de Pira, demonstraram sempre grande carinho. Ao amigo Jonas pela amizade e grandes conversas!

Às amigas do Depto. de Engenharia Rural Fernanda e Dna. Lourdes, por todo o carinho e atenção sempre comigo demonstrados.

Um agradecimento eterno e especial aos amigos do Edifício Atlanta, Pedro, Odemir e Francisco, e a querida amiga Maria, por toda a amizade e carinho por mim demonstrados ao longo dos anos queridos de Pira.

Aos novos amigos de empresa e de república, em Itapaci/GO, Fabiano, Marcelo, Edmar e Carlos, pela amizade e receptividade, tão importantes nessa nova etapa da minha vida profissional. 


\section{SUMÁRIO}

Página

LISTA DE FIGURAS ............................................................................

LISTA DE TABELAS ........................................................................

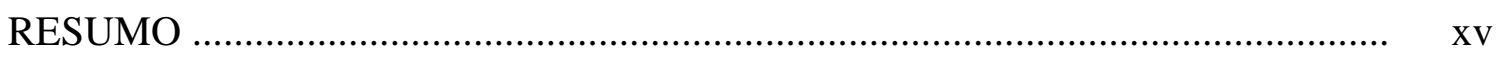

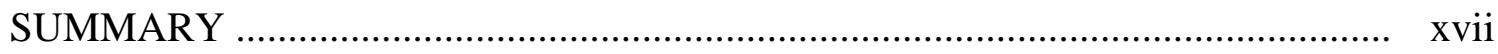

1 INTRODUÇÃ

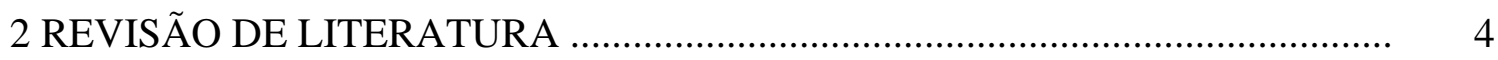

2.1 Logística: Conceitualização e Perspectiva Brasileira ....................................... 4

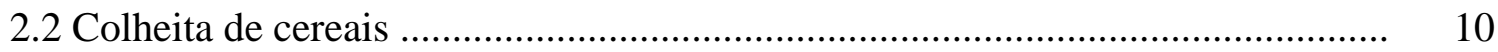

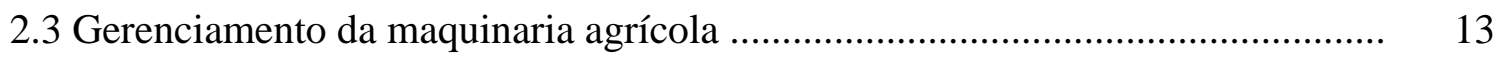

2.3.1 Desempenho das operações ......................................................................... 14

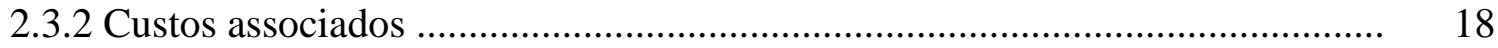

2.4 Modelagem e suas aplicações em mecanização agrícola .................................. 18

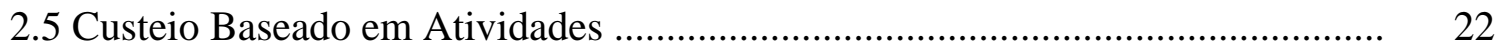

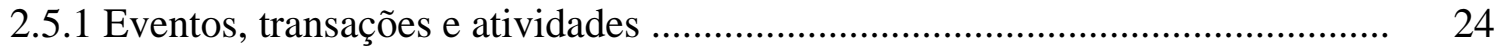

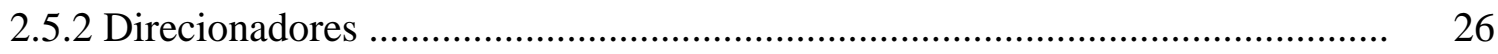

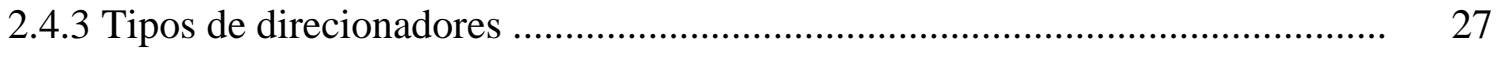

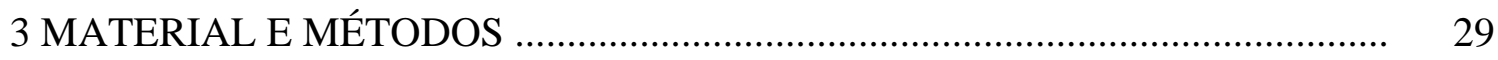

3.1 Problema inicial e sistemas de colheita ........................................................ 29

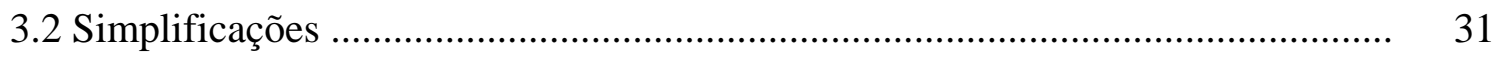

3.3 Algoritmo proposto ............................................................................... 31

3.4 Detalhamento e rotinas de cálculo ............................................................. 33

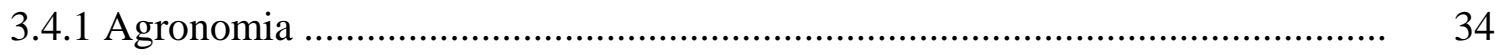




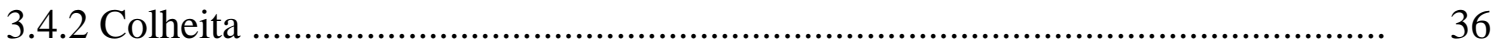

3.4.3 Transbordo e Transporte .................................................................... 40

3.5 Linguagem computacional ................................................................ 42

3.6 SisColhe: verificação da rotina ....................................................................... 43

3.7 SisColhe: validação .............................................................................. 43

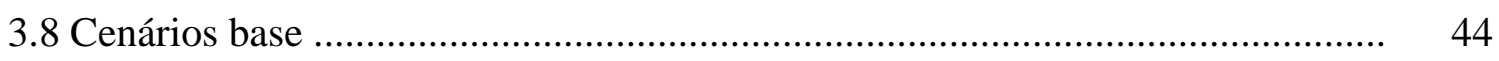

3.9 Parâmetros de destaque: identificação e ordenação.......................................... 46

3.10 Custos: estrutura e alocação dos recursos....................................................... 47

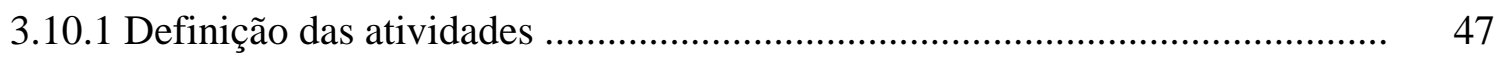

3.10.2 Explicitação dos recursos ...................................................................... 49

3.10.3 Alocação dos recursos às atividades ...................................................... 50

3.11 Desempenho de maquinaria: análises de comportamento e interações ............. 51

3.12 Estratégias de Colheita: elaboração............................................................ 51

3.12.1 Planejamento do prazo de retirada .......................................................... 51

3.12.2 Retirada de transbordos ...................................................................... 53

3.13 Comparativo entre sistemas ….................................................................. 53

4 RESULTADOS E DISCUSSÃO ............................................................. 54

4.1 SisColhe: verificação da rotina ..................................................................... 54

4.2 SisColhe: validação ............................................................................. 54

4.2.1 Validação quanto a custo ........................................................................... 54

4.2.2 Validação quanto a desempenho ............................................................ 56

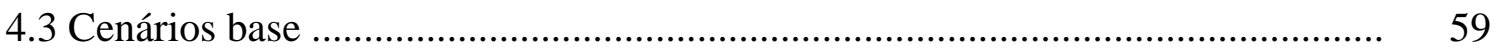

4.4 Parâmetros de destaque: identificação e ordenação .......................................... 61

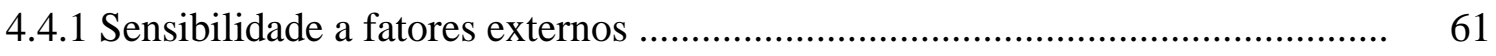

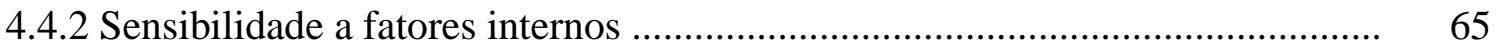

4.5 Custos: estrutura e alocação dos recursos .......................................................... 67

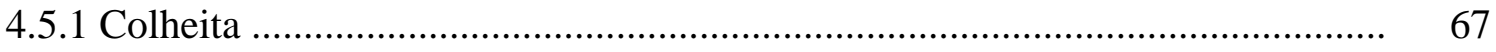

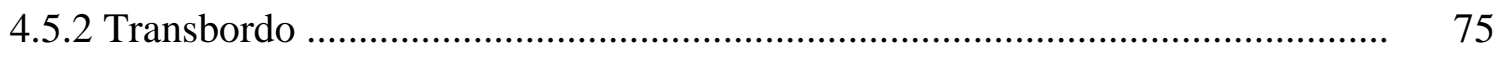

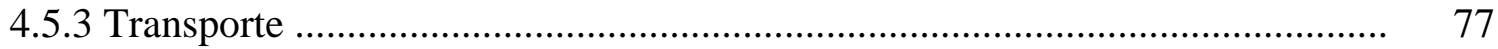

4.6 Desempenho de maquinaria: análises de comportamento e interações ............... 79 
4.6.1 Colheita .........................................................................................

4.6.1.1 Capacidade efetiva ................................................................................. $\quad 79$

4.6.1.2 Formato de talhão .................................................................................... 82

4.6.1.3 Níveis de eficiência ................................................................................ 83

4.6.1.3 Utilização anual ..................................................................................... 86

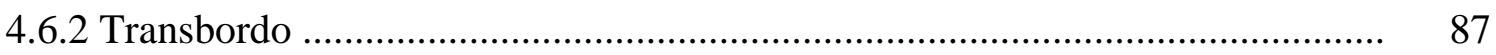

4.6.2.1 Capacidade de colheita .......................................................................... 88

4.6.2.2 Posicionamento dos veículos ................................................................ 90

4.6.3 Transporte ............................................................................................. 92

4.6.3.1 Tempo de carga e descarga ................................................................. 92

4.6.3.2 Capacidade de carga útil dos veículos ........................................................... 97

4.6.3.3 Distância de rota ....................................................................................... 100

4.6.3.4 Horas-ano de utilização dos veículos ............................................................. 100

4.7 Estratégias de Colheita: análise..................................................................... 101

4.7.1 Planejamento do prazo de retirada da produção ............................................... 102

4.7.1.1 Cenário 1: Limitação por capacidade de recebimento ..................................... 104

4.7.1.2 Cenário 2: Limitação por capacidade de maquinaria ...................................... 106

4.7.2 Sistema sem transbordos ....................................................................... 109

4.8 Comparativo entre sistemas ........................................................................... 118

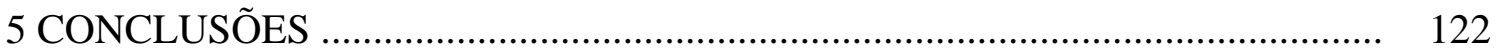

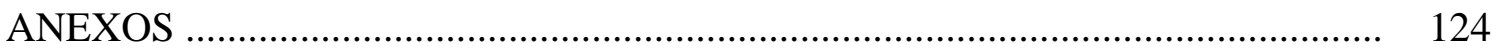

REFERÊNCIAS BIBLIOGRÁFICAS .......................................................... 140 


\section{LISTA DE FIGURAS}

Página

1 Modelo conceitual de logística integrada .................................................... 8

2 Fluxo de etapas em uma colhedora de cereais típica ....................................... 12

3 As atividades de custo como processamento de uma transação, na interseção

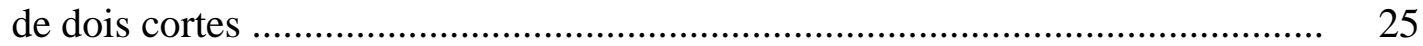

4 Relação entre os recursos e as atividades de custo ........................................... 27

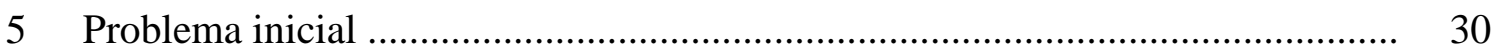

6 Subsistemas utilizados na elaboração do algoritmo e confecção do modelo ...... 31

$7 \quad$ Fluxograma - esquema estrutural do algoritmo proposto para o modelo ............ 33

8 Fluxograma do algoritmo Agronomia ......................................................... 35

$9 \quad$ Fluxograma do algoritmo Colheita ............................................................ 37

10 Fluxograma dos algoritmos Transbordo e Transporte ..................................... 41

11 Validação quanto ao custo horário de colhedoras .......................................... 55

12 Validação quanto ao custo horário de tratores .................................................. 55

13 Validação quanto ao custo quilométrico de veículos ........................................ 56

14 Validação quanto a duração das atividades de ciclo - colhedoras ..................... 57

15 Validação quanto a duração das atividades de ciclo - carretas graneleiras ......... 58

16 Validação quanto a duração das atividades de ciclo - veículos ......................... 59

17 Distribuição percentual dos custos totais dos cenários base entre os seus subsistemas: Colheita , Transbordo e Transporte ............................................. 61

18 Os efeitos nos custos dos cenários em função de alterações nos parâmetros

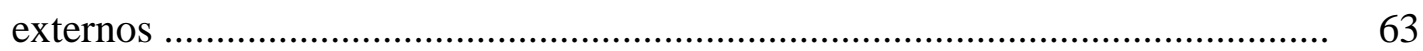

19 Incrementos de custo dos cinco parâmetros externos de maior destaque ........... 65 
20 Os efeitos nos custos dos cenários em função de alterações nos parâmetros que os reduzem

21 Reduções de custo dos cinco parâmetros internos de maior destaque

22 Comportamento do custo unitário de colheita frente à acréscimos na área a ser colhida

23 O efeito contrastante dos custos fixos e variáveis frente à: (a) custos operacionais anuais e (b) custos operacionais específicos

24 Ordenação dos recursos utilizados na retirada da produção por participação percentual

25 Comparativo entre o consumo de recursos pelas atividades de transbordo

26 Frota de Colhedoras - curvas de comportamento de capacidade efetiva e de custo mediante variações em suas velocidades de colheita

27 Frota de colhedoras - custos de colheita para plataformas de seis diferentes tamanhos

28 Diferença entre os custos de colheita nos dezesseis talhões simulados e o custo médio no período

29 Número de ciclos por colhedora e de horas-máquina necessárias à totalização da operação

30 Número de colhedoras requerido por sistemas com distintas taxas de eficiência

31 Incremento do custo de colheita como função do número de horas-ano de utilização da frota

32 Comportamento da capacidade de transbordo e do tempo de carregamento das carretas graneleiras frente à variações na capacidade de colheita

33 Comportamento do número e do custo de transbordo dos conjuntos trator e carreta graneleira frente à variações na capacidade de colheita

34 Redução das capacidades de transbordo e de transporte do sistema frente à alterações no posicionamento dos veículos

35 Variações no número de transbordos e veículos frente a diferentes distâncias de posicionamento dos veículos .................................................................... 92

36 Impacto relativo do tempo de carga/descarga sobre a distância da rota 
37 Participação do tempo de carga e descarga (média de três horas) no custo de

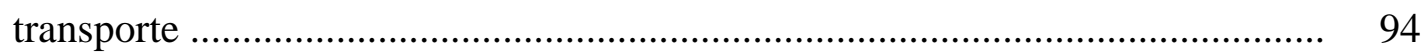

38 Curvas de capacidade de transbordo e transporte frente à eficiência de colheita 95

39 Incremento do tempo de carregamento de veículos frente à reduções de capacidade de transbordo

40 Variações na participação das duas categorias de custo de transporte em função da distância ..................................................................................... 97

41 Variações do custo unitário de transporte em função da capacidade de carga dos veículos

42 Incremento do custo de transporte em função de aumentos percentuais no comprimento das rotas

43 Reduções do custo de transporte em função de incrementos no número de horas-ano de utilização dos veículos

44 Comportamento dos custos finais de sistema, de colheita, de transbordo e de transporte mediante incrementos no prazo de retirada de produção

45 Dimensionamento da maquinaria frente à alterações na jornada diária de operação.

46 Taxa de incremento dos custos frente a alterações no posicionamento dos veículos

47 Redução da capacidade de colheita frente à alterações no posicionamento dos veículos

48 Custos finais dos três sistemas de colheita avaliados para distintas distâncias colhedoras-veículos 


\section{LISTA DE TABELAS}

Página

1 Eficiências e velocidades típicas em colheita de cereais ................................ 16

2 Principais características dos cenários base ................................................... 45

3 Resumo das principais características dos cenários de planejamento ................ 52

4 Custos e produções envolvidos com os cenários base A, B e C ........................ 60

5 Custos de colheita da safra agrupados por recurso .......................................... 68

6 Desagregação dos custos de colheita por recurso e por atividade ...................... 71

7 Desagregação dos custos das colhedoras por recurso e por atividade, sistema com transbordo intermediário, descarregamento sem movimento .................... 71

8 Comparativo entre diversos parâmetros de desempenho e de custo das colhedoras frente às duas formas de descarregamento .................................. 73

9 Desagregação dos custos de transbordo por recurso e por atividade ................. 75

10 Direcionadores de recurso e custos envolvidos com o transporte da produção .. 77

11 Relatório Custos $A B C$ - Desagregação dos custos por recurso e por atividade ... 79

12 Variações do custo unitário de transporte em função da capacidade de carga de dez modelos de veículos

13 Capacidade de retirada de produção da frota frente à variações na eficiência de campo e no número de horas diário de operação

14 Desempenho e custo da maquinaria em função da forma de descarregamento, 250 t.dia $^{-1}$

15 Desempenho e custo da maquinaria obtidos com a redução do prazo de 6 para 2 semanas, 750 t.dia ${ }^{-1}$

16 Desempenho e custo da maquinaria, 750 t.dia ${ }^{-1}$ - Reformulação da frota 
17 Comparativo entre os sistemas com e sem transbordo

110

18 Desempenho e custo do sistema sem transbordo, 250 t.dia ${ }^{-1}$........................... 111

19 Desempenho e custo do sistema sem transbordo, 750 t.dia ${ }^{-1}$........................... 114

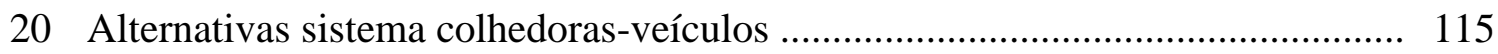

21 Alternativa verificada: alteração da jornada diária ...................................... 117 


\section{LOGÍSTICA APLICADA À COLHEITA MECANIZADA DE CEREAIS}

Autor: Saulo Salaber Souza e Silva

Orientador: Prof. Dr. Marcos Milan

\section{RESUMO}

A produção de cereais constitui uma das atividades de maior importância para o Brasil. O país ocupa posições de liderança na produção mundial, e é um dos principais exportadores. Para que tal desempenho seja cada vez mais superado, o mercado requer custos de produção competitivos e esse se constitui em um dos grandes desafios atuais da agricultura brasileira. Quanto à participação no custo final de produção da tonelada, a operação de colheita é destaque dentre as etapas que compõem o processo produtivo das principais culturas de cereais. Nas culturas do milho e da soja, o custo de suas atividades oscila entre 30 a $40 \%$ do total das operações. Mediante tal significância, estratégias de otimização que visem a redução de seu custo operacional, e que ofereçam subsídios para o seu adequado planejamento tornam-se cada vez mais necessárias. Tendo em vista a aplicação de conceitos logísticos no planejamento e coordenação da operação de colheita como um recurso potencial para a redução de seu custo e para a melhoria da qualidade de sua realização, o presente trabalho teve por objetivo analisar estratégias logísticas em sistemas de colheita de cereais. Em função da complexidade das inter-relações que os caracterizam, e do número envolvido de variáveis, optou-se por realizar as análises com 
base em um modelo computacional de simulação. SisColhe foi o nome escolhido ao programa de logística e simulação de colheita de cereais desenvolvido. As simulações características do estudo ocorreram a partir de três cenários hipotéticos. A partir do desenvolvimento dos cenários, norteou-se a avaliação das estratégias de colheita por seis distintas análises, compreendendo a definição do problema inicial e o desenvolvimento do algoritmo de simulação, a validação dos resultados do programa, a identificação dos parâmetros de maior contribuição para a formação do custo final da tonelada colhida e o entendimento das estruturas de custo e do desempenho operacional da maquinaria. Os resultados demonstraram que a parcela fixa dos custos possui maior participação na formação do custo final da tonelada colhida do que os variáveis, e que o fator de maior contribuição ao aporte de capital é o valor com o qual as colhedoras são adquiridas no mercado. A capacidade de colheita da frota de colhedoras é o parâmetro no qual residem os maiores potenciais de redução de custo. Essa regeu, inclusive, o desempenho dos demais equipamentos, carretas de transbordo e veículos de transporte, demonstrando um comportamento sistêmico entre os componentes da maquinaria. Em se tratando do custo de movimentação de produção, as atividades de carga e descarga dos veículos foram as responsáveis pela maior parcela na formação dos custos de transporte. No planejamento da colheita, o correto dimensionamento da frota, em conjunto com adoção de estratégias alternativas de incremento de desempenho operacional, mostraram-se estratégias viáveis em sistemas caracterizados pela retirada de grandes produções em curtos intervalos de tempo. Os resultados das simulações demonstraram que o SisColhe está apto a auxiliar a análise e a avaliação da colheita mecanizada de cereais. A lógica de comportamento da maquinaria e de suas inter-relações pôde ser reproduzida. As diferenças de validação mostraram-se aceitáveis face às simplificações impostas ao algoritmo e à variabilidade intrínseca ao ambiente agrícola. 


\section{CEREALS MECHANIZED HARVEST LOGISTICS}

Author: Saulo Salaber Souza e Silva

Adviser: Prof. Dr. Marcos Milan

\section{SUMMARY}

Cereals production constitutes one of the most important agricultural activities to Brazil. The country occupies leadership positions in the world production, and it is one of the main exporters. So that such performance be each time more overcame, the market requests competitive production costs, and this is one of the brazilian agriculture great current challenges. Focusing the ton final production cost percentages distribution, the harvest operation is prominence among the main cereals cultures productive process stages. For corn and soybeans cultures, the cost of their activities oscillates among 30 to $40 \%$ of the total operations costs. By such significance, optimization strategies that seek for the reduction of its operational cost, and that create conditions for an better harvest planning become more and more necessary. Considering the application of logistical concepts in the harvest operation planning and coordination as a potential resource to the reduction of its cost and improvement of its accomplishment, the present work had for objective to analyze logistical strategies in cereals harvest systems. Due to the complexity of their interrelations, and to the involved variables number, it was decided to base the analyses on a computational simulation model. SisColhe was the chosen 
name to the logistics and cereals harvest simulation developed software. The simulations that compose the study happened taking in granted three hypothetical sceneries. The evaluation of the harvest strategies was oriented by six different analyses, comprising the initial problem definition and the development of the simulation algorithm, the program results validation, the most cost composition parameters identification and the cost structures and machinery operational performance behavior understanding. The results demonstrated that the fixed components have more participation in the harvest final cost composition than the varied ones, and the larger contribution factor to the capital a port is the value with which the harvesters are acquired. The fleet harvesters operational capacity is the parameter of largest cost reduction potential, since its influenced, besides, the performance of the others fleet equipments, demonstrating a systemic behavior among them. Taking in granted the cost of the production movement, the vehicles charge and discharge activities were the responsible for the largest transport costs portion. In the harvest planning, the correct fleet dimensioning, together with the adoption of performance increment alternative strategies were viable strategies in high productions and small time intervals characterized systems. The simulations results demonstrated that the SisColhe software is capable to aid the analysis and the evaluation of the cereals mechanized harvest. The machinery behavior logic and its interrelations could be reproduced. The validation differences were acceptable due to the algorithm simplifications imposed and to the intrinsic agricultural environmental variability. 


\section{INTRODUÇÃO}

A agricultura brasileira é hoje um dos setores econômicos mais estratégicos para a consolidação do programa de estabilização da economia, iniciado em 1994 com o

Plano Real. A grande participação e o efeito multiplicador do complexo agroindustrial no PIB, o peso dos produtos de origem agrícola na pauta de exportações e a contribuição do setor para o controle da inflação são exemplos de sua importância para o desempenho da economia brasileira nos próximos anos.

Em menos de duas décadas, a produção agrícola do país registrou um crescimento recorde. De 1985 a 2003, a safra de grãos saltou de 58 milhões para mais de 122 milhões de toneladas. Um crescimento como esse, de 111\%, é inédito na história da agricultura mundial. Para a safra 2003/2004, o MINISTÉRIO DA AGRICULTURA, PECUÁRIA E ABASTECIMENTO - BRASIL (2004) prevê mais uma colheita recorde, próxima a 130 milhões de toneladas. Tal produção é 5,5\% superior à alcançada na safra anterior. Para que tal desempenho seja cada vez mais superado, o mercado requer custos de produção competitivos, e esse se constitui em um dos grandes desafios atuais da agricultura brasileira.

Dentre as etapas que caracterizam o ciclo agrícola da produção de cereais, a colheita é uma operação de destaque. O custo das atividades envolvidas com a operação, nas culturas do milho e da soja, de acordo com FNP CONSULTORIA \& COMÉRCIO FNP (2004), oscila entre 30 e 40\% do custo total das operações agrícolas mecanizadas. Em se tratando do custo final de produção, no qual encontram-se contabilizados também os custos de administração, dos insumos e da pós-colheita, sua representatividade é de 7 a 12\%. Mediante tal significância, estratégias gerenciais que visem a redução dos custos 
da operação, e que ofereçam subsídios para a otimização de seu planejamento e de sua coordenação, tornam-se cada vez mais necessárias.

Nos últimos anos, a logística vem apresentando uma evolução constante, sendo hoje um dos elementos-chave na formação da estratégia competitiva das empresas. No inicio, era confundida com o transporte e a armazenagem de produtos. Hoje, ela pode ser considerada como o ponto nevrálgico da cadeia produtiva integrada, atuando em estreita consonância com o moderno gerenciamento da cadeia de suprimentos (Novaes, 2001).

De acordo com Fleury (2000), as recentes mudanças econômicas, dentre elas a globalização e o maior nível de exigências de serviços, vêm transformando a percepção empresarial sobre logística. Essa passou a ser vista não mais como uma simples etapa operacional, um centro de custos, mas sim uma atividade estratégica, um instrumento de marketing e de gerência, capaz de agregar valor por meio dos serviços prestados.

Atualmente, a colheita mecanizada de cereais passa por um intenso processo de modernização. As novas tecnologias que surgiram para o setor agrícola no Brasil a partir de meados da década de 90, como a agricultura de precisão, os Sistemas GPS e os conjuntos eletrônicos embarcados, bem como o tamanho e a sofisticação das máquinas e dos equipamentos, tornam o investimento em bens de capital não duráveis crescente, e elevam os riscos financeiros envolvidos. Em um ambiente novo e desafiador como esse, a realização de um planejamento adequado e a excelência na seleção e no gerenciamento da maquinaria são premissas indispensáveis ao sucesso da operação.

O planejamento do prazo de retirada da produção é também um fator decisivo. Os riscos de perda por falta de pontualidade e mediante a ação de fatores climáticos são grandes. Em função das características do sistema, os prazos podem ser limitados pelas unidades de recepção, caso essas não ofereçam condições para o recebimento da safra em intervalos de tempo reduzidos. Problemas como a adequação de equipamentos de recepção, secagem e armazenagem estão envolvidos. Inversamente, pode ocorrer que o fator limitante de sistema não seja a capacidade de recebimento das unidades, mas sim a capacidade de colheita da frota. Haja vista as distintas configurações entre colhedoras, carretas de transbordo e veículos de transporte de serem esperadas, o sincronismo ideal entre os equipamentos torna-se fator regente de seus desempenhos e custos. 
Concomitantemente, o transporte, tradicionalmente o elemento mais visível do processo logístico, assume relevância destacada nos modernos sistemas de colheita. $\mathrm{O}$ entendimento do comportamento e da inter-relação de parâmetros importantes, tais como os tempos de carregamento e descarregamento dos veículos, suas capacidades de carga e o distanciamento entre os talhões e as unidades de recepção é essencial ao cumprimento da meta de produção estabelecida. De modo semelhante, a aplicação de uma estrutura de custeio adequada pode permitir uma melhor compreensão da origem e do volume dos recursos consumidos nas operações, e um melhor discernimento quanto ao grau de utilização da frota e de suas ineficiências.

Tendo em vista a aplicação de conceitos logísticos no planejamento e na coordenação da operação de colheita como um recurso em potencial para a redução de seu custo e para a melhoria da qualidade de sua realização, o presente trabalho teve por objetivo analisar estratégias logísticas em sistemas de colheita de cereais. Em função da complexidade de suas inter-relações e do número envolvido de variáveis, optou-se por realizar as análises com base em um modelo computacional de simulação. Estabeleceuse, assim, como objetivos específicos:

(i) desenvolver um modelo de simulação que permita a avaliação e a análise de sistemas de colheita de cereais ao nível operacional e econômico e;

(ii) utilizá-lo na identificação de variáveis críticas e de alternativas logísticas de redução de custos e de melhoria da qualidade de realização das atividades que caracterizam a operação de colheita. 


\section{REVISÃO DE LITERATURA}

\subsection{Logística: Conceitualização e Perspectiva Brasileira}

Ao longo da história do homem, as guerras têm sido ganhas e perdidas através do poder e da capacidade da logística, ou de sua falta. O deslocamento de suprimentos e de tropas, em grandes distâncias, e em um curto espaço de tempo, se constituiu em um exercício logístico altamente proficiente, e determinou vitórias, ou derrotas, em diversas ocasiões (Christopher, 1997).

Embora o conhecimento das atividades logísticas remonte séculos, o termo surgiu apenas durante a Segunda Guerra Mundial, quando foi usado para definir o conjunto de atividades relacionadas à movimentação de recursos humanos, armamentos e munições para os campos de batalha. Recentemente, com as investidas militares de grande porte praticadas pelo exército americano, como na Guerra do Golfo, no início da década de 90, e em território afegão, em 2001/02, ocorreu uma nova popularização do termo logística em ambiente estratégico militar (Schmitt, 2002).

Uma das origens da palavra logística, segundo Alves (2000) e Colli (2001), pode ser encontrada em sua etimologia francesa. Ela é originada do verbo loger, que significa alojar. Em sua raiz militar, teve como primeiro objetivo integrar, de forma eficiente, nos campos de batalha, o tempo, os custos e os recursos disponíveis. Com o passar dos anos, o seu significado tornou-se mais amplo, passando a abranger outras áreas, como o estoque, o transporte e a armazenagem.

Na sua origem, o conceito de logística era essencialmente ligado às operações militares. Por se tratar de um serviço de apoio, sem o glamour da estratégia bélica e sem o prestigio das batalhas ganhas, os grupos logísticos militares operavam quase sempre 
em silêncio. Foi o que também ocorreu nas empresas durante um bom período de tempo (Novaes, 2001).

Nas últimas décadas, a logística vem apresentando uma evolução constante, sendo tida hoje como um dos elementos-chave na formação da estratégia competitiva das empresas. No inicio, era confundida com o transporte e a armazenagem de produtos, um mero centro de custos. Hoje, ela é considerada como o ponto nevrálgico da cadeia produtiva integrada, atuando em estreita consonância com o moderno Gerenciamento da Cadeia de Suprimentos (Novaes, 2001).

O conceito de logística empresarial é bastante recente no Brasil. Fleury et al. (2000) descrevem que o processo de difusão teve inicio, de forma ainda tímida, no inicio dos anos 90, com o processo de abertura comercial, mas se acelerou somente a partir de 1994, com a estabilização econômica propiciada pelo Plano Real. O que se viu, a partir de então, foi o desenrolar de um processo revolucionário, tanto em termos de práticas empresariais, quanto de eficiência, de qualidade e de disponibilidade de infra-estruturas de transporte e de comunicações. Para as empresas que operam no país, tal como relatam os autores, os tempos atuais representam um período de riscos e de oportunidades. Riscos devido às enormes mudanças que precisam ser implementadas, e, oportunidades, devido aos grandes espaços para melhorias de qualidade de serviço e de aumento de produtividade, fundamentais para o incremento de vantagem competitiva.

Apesar de amplo, o movimento de mudanças é ainda recente. Até meados de 90, a logística foi o elo perdido da modernização empresarial no país. A explosão do comércio internacional, a estabilização econômica proporcionada pelo Real e as privatizações das infra-estruturas foram os fatores de maior impulso à esse processo de mudanças. De 1994 a 1997, o comércio exterior brasileiro saltou de um volume de US\$ 77 bilhões para cerca de U\$ 115 bilhões, um crescimento de 50\% em 3 anos (Fleury et al., 2000).

Ao nível empresarial, a modernização vem sendo liderada por dois segmentos, o automobilístico e o de grande varejo. Nos últimos anos, todas as montadoras instaladas no país fizeram mudanças radicais em suas linhas de suprimento, passando a combinar compras internacionais com locais, com base no sistema just in time. No setor varejista, 
a Associação Brasileira de Supermercados (ABRAS) deu inicio ao movimento ECR Brasil, visando reduzir custos e melhorar a qualidade dos serviços. Também, tanto o grupo Pão de Açúcar quanto as Lojas Americanas investiram forte em processos de automação de suas comunicações, permitindo-lhes uma maior interligação com os seus fornecedores (Fleury et al., 2000).

A logística é um verdadeiro paradoxo. É, ao mesmo tempo, uma das atividades econômicas mais antigas e um dos conceitos gerenciais mais modernos. Desde que o homem abandonou a economia extrativista, e deu inicio às atividades produtivas organizadas, com produção especializada e troca de excedentes, surgiram três das mais importantes funções logísticas: estoque, armazenagem e transporte (Fleury, 2000).

Entretanto, somente num passado recente é que as organizações empresariais reconheceram o impacto vital que o gerenciamento logístico pode ter na obtenção da chamada vantagem competitiva (Christopher, 1997). Bowersox \& Closs (2001), em concordância com Novaes (2001), relatam que, antes da década de 50, não havia conceito formal ou teoria sobre logística integrada. Nessa época, as funções hoje aceitas como logísticas eram geralmente consideradas como operações de apoio ou de suporte, um centro de custos.

Para Fleury (2000), o que vem fazendo da logística um dos conceitos gerenciais mais modernos são dois conjuntos de mudanças. O primeiro é de ordem econômica. Dentre as principais, a globalização, o aumento das incertezas nos mercados, a proliferação de produtos e as maiores exigências de serviços. Em seu conjunto, esse grupo vem transformando a visão empresarial sobre logística, que passou a ser vista não mais como uma simples atividade operacional, mas sim como uma atividade estratégica, uma ferramenta gerencial, fonte potencial de vantagem competitiva.

O segundo é de ordem tecnológica. Enquanto as mudanças econômicas criam novas exigências competitivas, as tecnológicas tornam possível o gerenciamento eficaz e eficiente de operações logísticas mais complexas e demandantes. Na base dessas novas tecnologias está a revolução da Tecnologia de Informação (TI). Microcomputadores, computadores de bordo, sistemas GPS, roteirizadores e simuladores são algumas das aplicações de hardware e software envolvidas. 
Mas a logística não é apenas mais uma ferramenta gerencial moderna. Ela é também uma importante atividade econômica, contribuindo de forma significativa tanto na estrutura de custos das empresas quanto no Produto Interno Bruto das nações. Lambert et al. (1998) citam que, nos EUA, ela contribui com 10\% do PIB, grandeza essa que equivale ao PIB brasileiro. Embora não existam levantamentos específicos, estimase que, no Brasil, os gastos com as atividades logísticas correspondam a cerca de $17 \%$ do PIB, com base no fato de que os gastos com transporte correspondem a $10 \%$ desse e que, na média, o transporte corresponda a 60\% dos custos logísticos (Fleury, 2000).

Existem muitas maneiras de definir a logística como hoje ela é entendida. Diversos autores, dentre eles Lambert \& Stock (1992), Ballou (1993), Christopher (1997), Lambert et al. (1998), Imam (2000) e Ballou (2001) o fizeram, em distintas abordagens. O que todas demonstram em comum é que elas se referem, essencialmente, ao mesmo principio: o gerenciamento do fluxo de bens e serviços do ponto de origem ao de consumo e, em alguns casos, novamente ao ponto de origem.

Segundo Lambert et al. (1998), o Council of Logistics Management, entidade norte americana que tem, por objetivo, desenvolver a teoria e a compreensão da logística, define o gerenciamento logístico como o processo de planejar, implementar e controlar o fluxo e o armazenamento de bens, serviços e informações correlatas, de forma eficiente e economicamente eficaz, do ponto de origem de consumo, com o propósito de satisfazer as necessidades dos consumidores.

Um conceito muito parecido é o de Christopher (1997). Para o autor, a logística é definida pelo gerenciamento estratégico da aquisição, da movimentação e da armazenagem de materiais, peças, produtos acabados e informações correlatas, através da organização e seus canais de marketing, de modo a poder maximizar as lucratividades presente e futura através do atendimento dos pedidos a baixo custo.

Essa última mostra a premissa essencial que fundamenta o moderno conceito logístico. Para Fleury (2000), na base desse está o entendimento de que a logística deve ser tida como um instrumento de marketing, uma ferramenta gerencial, capaz de agregar valor por meio dos serviços prestados. Dois conceitos ajudam a explicar tal enfoque. A Figura 1 os apresenta graficamente. 


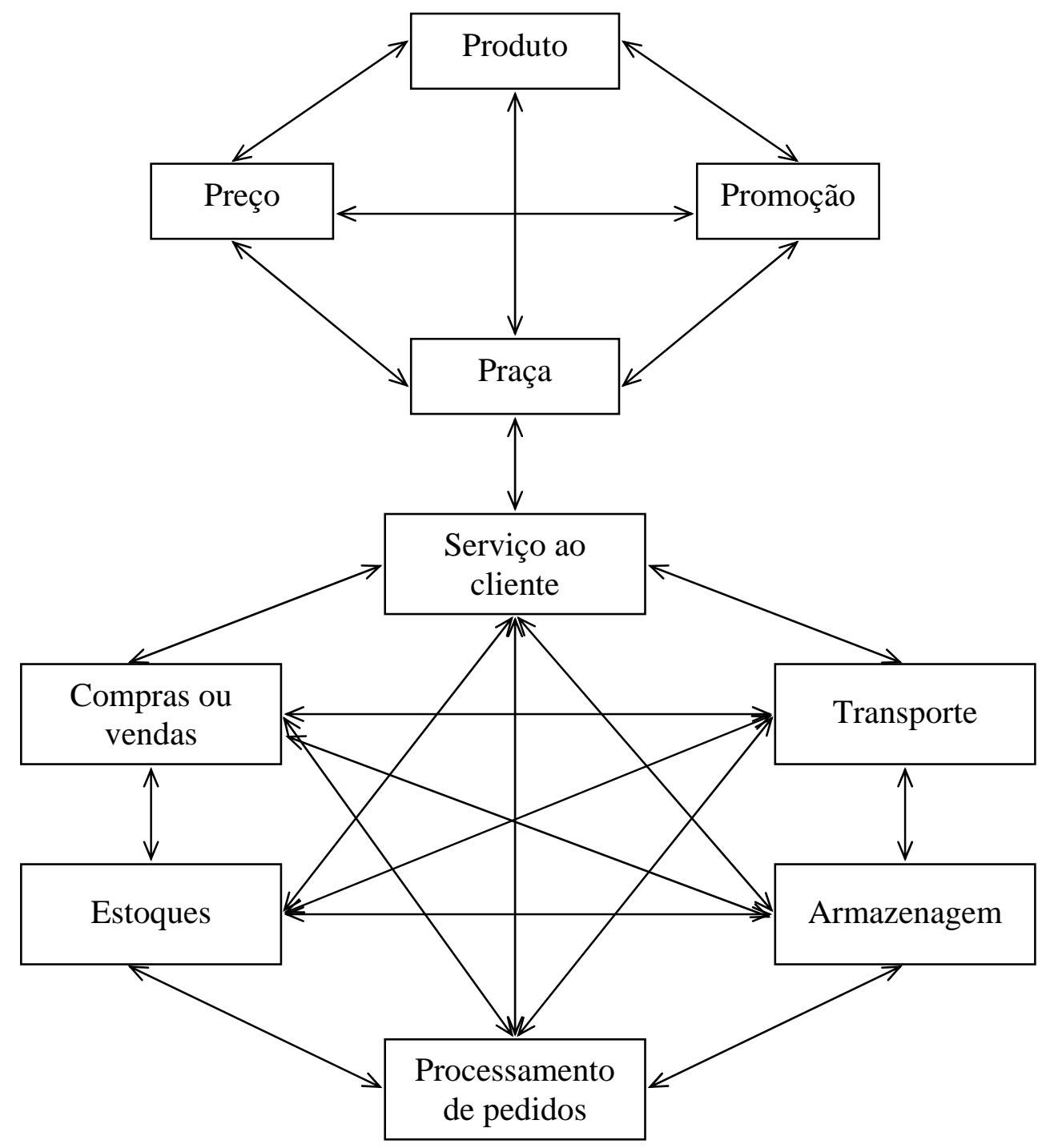

Figura 1 - Modelo conceitual de logística integrada

Adaptado de Lambert \& Stock (1992)

O primeiro representa a formulação da estratégia de marketing, esquematizada na parte superior da Figura 1. A estratégia de marketing é definida pela ênfase relativa dada em cada uma das variáveis produto, preço, promoção e praça. Decisões sobre praça passam pelo estabelecimento de políticas a respeito de canais de distribuição e padrões de serviço. Nesse último estão incluídos fatores como a disponibilidade dos produtos, os prazos de entrega, a consistência dos prazos, a flexibilidade dos serviços e os serviços pós-venda. Uma vez estabelecidos os canais de distribuição e seus respectivos padrões 
de serviço, cabe à logística a missão de estruturar-se para garantir seu cumprimento. A política de serviço ao cliente, componente esse central da estratégia de marketing, sob o ponto de vista operacional, se transforma na missão a ser cumprida pela organização logística (Fleury, 2000).

O segundo conceito é de logística integrada, sistêmica. A visão sistêmica é um conceito crítico em logística. A logística é, por si própria, um sistema. É uma rede de atividades inter-relacionadas com o propósito de gerenciar o fluxo ordenado de materiais e de pessoas através do canal logístico (Lambert et al., 1998). Assim, a visão sistêmica é chave para a compreensão da função logística na economia e nas organizações e de sua interface com o marketing.

Bowersox \& Closs (1996) relatam que a prática tradicional das empresas tem sido desempenhar funções específicas em uma base independente. Segundo eles, o transporte e o estoque sempre foram gerenciados em separado, com pouca ou nenhuma atenção dada às suas inter-relações. Contudo, desempenhos isolados podem criar sérias barreiras ao alcance dos objetivos da logística integrada. Em uma análise final, pouco importa quanto uma empresa desprende realizando qualquer atividade individual, desde que os objetivos finais de seu desempenho logístico sejam realizados ao menor custo total.

Quando o gerenciamento é regido por uma orientação sistêmica, sua atenção é direcionada à interação de todas as partes do sistema (Bowersox \& Closs, 1996). A parte inferior da Figura 1 apresenta o conceito de sistema logístico, em que os retângulos representam os seus componentes e, as setas, os trade-offs entre os mesmos. Para Fleury (2000), a logística deve atender os níveis de serviço ao cliente definidos pela estratégia de marketing, ao menor custo total de seus componentes, ou seja, o somatório dos custos de transporte, armazenagem, processamento de pedidos, estoques, compras e vendas. Tentativas isoladas de atuar sobre qualquer um desses podem representar aumentos nos custos dos outros componentes, ou deteriorações do nível de serviço. A fim de entender as oportunidades de redução de custo, e as suas implicações, o sistema deve ser visto como um todo (Lambert et al., 1998). 
O principal componente do sistema é o serviço ao cliente. Na seqüência, vêm o trafego e o transporte, a armazenagem e a estocagem, a localização das plantas, o sistema de comunicação, o processamento de pedidos, o manejo de materiais, o suporte a peças e serviços, a embalagem e a previsão de demanda (Lambert \& Stock, 1992). Para que tais componentes sejam atendidos, uma série de ferramentas faz-se necessária ao planejamento e controle do processo logístico. São elas: previsão de vendas, controle de estoques, custos, simulação e sistema de informações geográficas.

Assim, observa-se que a logística evoluiu muito desde os seus primórdios. Nos últimos anos, ela vem sendo reconhecida como uma oportunidade impar de crescimento, rentabilidade e competitividade para as empresas (Lambert et al., 1998). Ela aprimora os esforços de marketing, criando condições de vantagem competitiva no mercado. Agrega valor de lugar, de tempo, de qualidade e de informação à cadeia produtiva. Além disso, procura eliminar do processo tudo o que não tenha valor ao cliente, tudo o que acarrete somente custos e tempo improdutivo (Novaes, 2001). Implica também em otimização de recursos pois, se de um lado são almejados o aumento de eficiência e a melhoria da qualidade de realização dos serviços, do outro a competição no mercado obriga uma redução continua de custos.

Fleury (2000) sumariza em seis as dimensões a serem alcanças pelas empresas na busca por sua excelência logística: sucesso do cliente, integração interna, integração externa, processos baseados no tempo, mensuração abrangente e benchmarking.

\subsection{Colheita de cereais}

Os sistemas de produção agrícola se caracterizam por uma seqüência ordenada de atividades, denominadas, assim, de operações agrícolas. Essas são realizadas de modo cronológico, acompanhando as fases de instalação e desenvolvimento da cultura. A colheita é a última operação desempenhada, e tem por objetivo retirar o produto agrícola das demais partes do organismo vegetal, em um tempo hábil tal que permita a mínima perda quantitativa e o alcance do máximo nível de qualidade (Mialhe, 1984; Srivastava et al., 1993). 
Segundo Mialhe (1984), cereal é a designação genérica do produto agrícola constituído de grãos amiláceos contidos em cachos (arroz, trigo, cevada, centeio, aveia, sorgo e gramíneas forrageiras), em vagens (soja e feijão), em inflorescências (girassol) ou em espigas (milho).

O processamento da colheita de cereais pode ser feito por três sistemas: manual, semi-mecanizado e mecanizado. Sua seleção depende do grau de mecanização permitido pela cultura, das condições de relevo e dos fatores econômicos. Esse último é o parâmetro que indica se é compensatório o produtor investir na melhoria da eficiência de um sistema de colheita manual, ou se os custos decorrentes indicam ser mais razoável evoluir para o processo semi-mecanizado ou totalmente mecanizado (Silveira, 1987).

A colheita manual é aplicável em pequenas áreas e sob condições econômicas e/ou técnicas que inviabilizem o emprego de máquinas, nas quais a finalidade principal da produção seja a subsistência do agricultor e de sua família (Balastreire, 1987). Neste processo, todas as atividades requeridas à execução das operações de corte, de trilha e de limpeza são efetuadas em separado, uma por vez, e utilizando energia muscular humana.

Em semelhança aos processos assim desempenhados, a colheita manual se caracteriza por uma baixa capacidade operacional, o que a torna inviável para grandes produções. A redução do número de pessoas trabalhando na agricultura e a necessidade de maior produção de alimentos, devido ao aumento da população, levou à crescente demanda de mecanização das etapas de produção (Glanze, 1972). Santos \& Mantovani (1997) relatam que 53\% da colheita de milho no Brasil é ainda realizada de modo manual, em reflexo às pequenas propriedades produtoras existentes no país. Para a colheita de soja, nenhum referencial foi encontrado. Os procedimentos da operação de colheita manual são descritos em detalhe por Cati (1973).

Na colheita semi-mecanizada, o inicio do processamento ocorre manualmente, com a operação de corte sendo desempenhada com o auxilio de ferramentas manuais. $\mathrm{O}$ material é cortado, enfeixado e amontoado manualmente. O objetivo é possibilitar a présecagem do produto, até que esse atinja teores de umidade que permitam a trilha e a limpeza. Após a maturação, procede-se as etapas de recolhimento, a trilha e a limpeza, todas realizadas mecanicamente. 
Na colheita mecanizada são distinguidos dois sistemas: indireto e direto. No primeiro, a etapa de corte é realizada por uma segadora, sendo o material cortado deixado no campo para secar. Após, procede-se o recolhimento, a trilha e a limpeza, em uma só operação, efetuada por uma colhedora combinada equipada com um dispositivo recolhedor. No segundo, todas as operações são realizadas simultaneamente por uma só máquina, a colhedora combinada.

A colheita mecanizada de cereais envolve as etapas de corte, alimentação, trilha, separação e limpeza. Quando uma única maquina realiza todas as operações citadas, e é também auto-propelida, essa é chamada colhedora combinada. De modo independente da forma de acoplamento da colhedora à fonte de potência, essa dispõe normalmente de diversos sistemas com funções específicas, que realizam as cinco operações que constituem o processo de colheita. Diversos autores, dentre eles Richey (1961), Kepner (1972), Ridenour (1981), Griffin (1991), Ortíz-Cañavate (1993), Srivastava et al. (1993) e Quick \& Buchele (2000) descrevem os seus princípios de funcionamento. O fluxo de operações realizadas por uma colhedora de cereais típica é apresentado pela Figura 2.

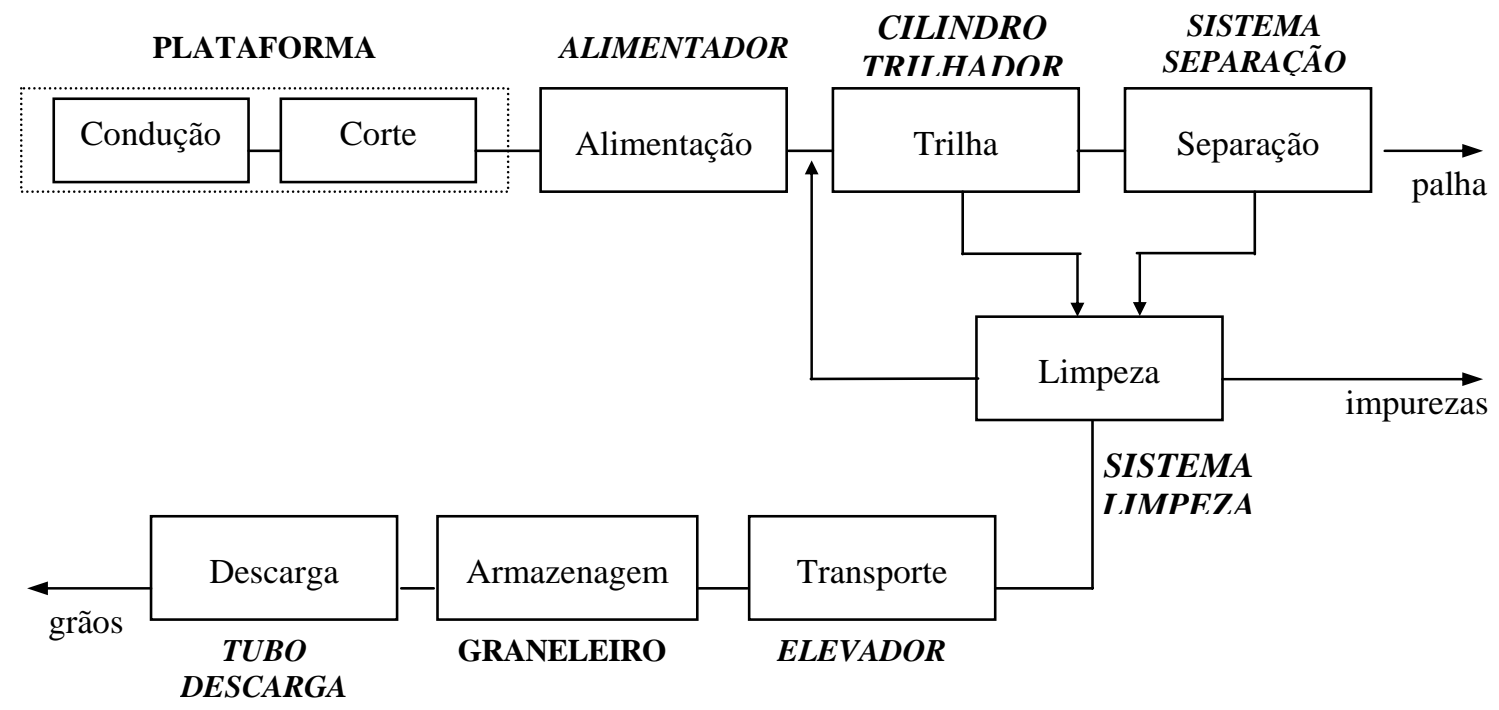

Figura 2 - Fluxo de etapas em uma colhedora de cereais típica Adaptado de Srivastava et al. (1993) 


\subsection{Gerenciamento da maquinaria agrícola}

Ao longo de sua evolução, a agricultura tem se tornado cada vez mais dependente de máquinas no sustento de sua produção. Hunt (1977) descreve que, já na década de 70, um único produtor possuía a capacidade de fornecer alimentos e fibras para uma média estimada de 46 outras pessoas. Dentre os fatores que contribuíram para o aumento da capacidade produtiva do homem do campo, a mecanização das operações figura entre as posições de destaque. Indubitavelmente, essa se constitui em uma das mais importantes inovações tecnológicas incorporadas ao processo produtivo.

Witney (1988) lembra que existe uma demanda continua de avanços que permitam metas de produção mais elevadas, principalmente face à menores retornos de mercado. Também, padrões de qualidade mais estreitos exigem cada vez maiores ênfases em pontualidade e em confiabilidade. Embora a mecanização invariavelmente cause um certo fascínio aos olhos de quem está e de quem não está diretamente envolvido com a produção, para quem se envolve com o gerenciamento da produção, e de seus custos, as máquinas são muito mais que um desafio. Nesse caso, elas representam a solução e a viabilização de sistemas e, ao mesmo tempo, uma parcela significativa na composição dos custos (Molin \& Milan, 2002).

O gerenciamento da maquinaria é a seção do gerenciamento agrícola que tem por preocupação a otimização dos estágios mecanizados da produção (Hunt, 1977). Ele tem, como ponto primordial de enfoque, a excelência na seleção, na operação, no reparo e manutenção e na reposição da maquinaria.

Inegavelmente, em muitas fazendas, as máquinas são operadas por tradição, por fins terapêuticos, e até mesmo por prazer. Entretanto, a empresa agrícola de sucesso, composta, tal como ela é, por diversos setores, para os quais as máquinas são apenas ferramentas de produção, opera seus equipamentos de forma profissional, e visa tornar os seus bens produzidos retorno econômico (Hunt, 1977).

O ótimo gerenciamento da maquinaria ocorre quando a rentabilidade de toda a produção tiver sido maximizada. Assim, a minimização do custo das operações não é necessariamente o objetivo econômico a ser perseguido (Hunt, 1977; Witney, 1988). Ele passa pela maximização da lucratividade da produção em seu estágio final, o que não 
necessariamente ocorre com um conjunto de operações de custo mínimo. Com esse enfoque, o bom gerenciamento requer que as operações que compõem os sistemas sejam ajustadas de modo que os seus desempenhos, ao final, propiciem melhores retornos aos investimentos.

\subsubsection{Desempenho das operações}

O desempenho de uma máquina agrícola é determinado pela capacidade com que essa efetua as suas operações e pela qualidade final de seus produtos (Witney, 1988). Na área agrícola, a relevância dessas medidas difere da industria. A capacidade é importante devido à sazonalidade intrínseca às etapas produtivas, bem como às incertezas do clima. Por outro lado, a natureza perecível e frágil dos produtos agrícolas enfatiza o cuidado na realização das operações, sob pena de aumento de dano às culturas.

A capacidade de uma máquina agrícola é tipicamente reportada em quantidade por unidade de tempo, e inclui a capacidade em termos de área e a capacidade em termos de produção. A capacidade de área é utilizada na identificação da taxa de trabalho de operações nas quais a área coberta é a medida mais direta do trabalho realizado, como ocorre para as operações de plantio, pulverização e preparo do solo.

A maioria dos parâmetros de desempenho é reportada pela área coberta na unidade de tempo. Contudo, quando expressa desse modo, a capacidade pode não ser o indicador mais apropriado. Em operações de colheita, o reporte em termos de produção por tempo é um indicador melhor, uma vez que também acomoda variações de produtividade nas culturas. Caso não sejam levadas em consideração, as diferenças podem gerar situações em que uma máquina apresenta uma baixa capacidade em ha. $\mathrm{h}^{-1}$, e uma alta em t.h ${ }^{-1}$, o que prejudica a comparabilidade de seu desempenho.

De acordo com Mialhe (1974), as dimensões dos órgãos ativos das máquinas e dos implementos e o intervalo de tempo considerado nas avaliações, distinguem três tipos de capacidades, a saber: (i) capacidade teórica $\left(\mathrm{CC}_{\mathrm{T}}\right)$; (ii) Capacidade efetiva $\left(\mathrm{CC}_{\mathrm{E}}\right)$ e (iii) capacidade operacional $\left(\mathrm{CC}_{\mathrm{O}}\right)$. 
A capacidade teórica é a máxima capacidade de área possível em uma determinada velocidade, e é obtida pela utilização completa da largura de trabalho da máquina. Ela é obtida a partir das dimensões de seus órgãos ativos e da sua velocidade de deslocamento. Essa última correspondente ao limite máximo de velocidade sob o qual torna-se possível realizar um trabalho adequado, sob as condições operacionais definidas pelo fabricante.

Já a efetiva, representa a capacidade efetivamente demonstrada pela máquina no campo. Ela constitui-se na capacidade básica da máquina, isto é, a capacidade medida na operação durante certo intervalo de tempo. A $\mathrm{CC}_{\mathrm{E}}$ diferencia-se da $\mathrm{CC}_{\mathrm{T}}$ devido ao efeito de variações como a sobreposição entre passadas sucessivas e a aplicação de velocidades inferiores àquelas que teoricamente a máquina poderia desenvolver. Também, na prática, apenas um percentual da largura nominal é aproveitado na operação. Para colhedoras de grãos, esse oscila entre 80 e 90\% (Hunt, 1977).

Embora a capacidade efetiva seja um importante parâmetro de referencia, e seja a melhor opção na comparação de desempenho de máquinas distintas, ela exclui qualquer distorção relativa ao planejamento inadequado dos sistemas ou a realização da operação. É usualmente impossível operar as máquinas continuamente, em função da presença de tempos não produtivos indispensáveis às operações. Com isso, as capacidades reais são substancialmente inferiores às efetivas, tornando-as capacidades potenciais. A CC $\mathrm{O}$ é o parâmetro utilizado a fim de refletir a influencia desses fatores.

Um indicativo do quão bem realizada foi a operação é obtido por um parâmetro denominado eficiência de tempo. Algumas de suas definições e metodologias de cálculo são propostos por Bainer et al. (1955), Renoll (1972), Von Bargen \& Cunney (1974) e Renoll (1981).

De acordo com Hunt (1977), esse reporta a razão entre o tempo em que a máquina é efetivamente operada e o tempo total disponível. Quando são consideradas apenas as atividades que ocorrem nos talhões, a eficiência de tempo passa a ser denominada eficiência de campo, reportando a razão entre a $\mathrm{CC}_{\mathrm{O}}$ e a $\mathrm{CC}_{\mathrm{E}}$. Dessa forma, a eficiência pode ser entendida como uma taxa de aproveitamento da capacidade 
potencial. Quanto mais eficiente for o sistema, maior a taxa de aproveitamento e maior a capacidade que as máquinas possuem em realizar a operação na qual foram empregadas.

A eficiência de máquinas de categorias diversas pode variar amplamente. A Tabela 1 apresenta os valores sugeridos para aquelas que operam em colheita (ASAE, 1999b).

Tabela 1. Eficiências e velocidades típicas em colheita de cereais

\begin{tabular}{lcccc}
\hline \multirow{2}{*}{ Máquina } & \multicolumn{2}{c}{ Eficiência (\%) } & \multicolumn{2}{c}{ Velocidade $\left(\mathrm{km}^{\left.-\mathrm{h}^{-1}\right)}\right.$} \\
& Faixa & Típica & Faixa & Típica \\
\hline Colhedora c/ plataf. milho & $60-75$ & 65 & $3,0-6,5$ & 4,0 \\
Colhedora combinada & $60-75$ & 65 & $3,0-6,5$ & 5,0 \\
Colhedora combinada AP & $65-80$ & 70 & $3,0-6,5$ & 5,0 \\
${ }^{*}$ auto-propelida. & & & &
\end{tabular}

Muitos dos fatores que afetam a eficiência de campo foram estudados até o inicio da década de 80. A maioria dos autores abordou as interações entre máquinas, talhões e clima por meio de uma análise sistêmica. Von Bargen (1966, 1967) a utilizou em seus estudo sobre colheitas de feno e alfafa. Stapleton \& Barnes (1967) também a aplicaram em seu trabalho com máquinas colhedoras de algodão. Link (1967) utilizou um conceito de análise em rede em seu estudo de seleção de maquinaria. Renoll (1972) fez-se valer de estudos de tempos e movimentos a fim de avaliar operações agrícolas consideração os efeitos das máquinas e da caracterização geométrica dos talhões. Von Bargen \& Cunney (1974) empregaram o conceito de taxa efetiva em sua pesquisa sobre gerenciamento da maquinaria. Renoll (1981) utilizou 14 coeficientes técnicos objetivando estimativas mais acuradas de capacidade para as operações de plantio, aração, pulverização e cultivo. Os valores predistos foram comparados com dados reais, sob um desvio inferior a $5 \%$.

Elevações em potencial da eficiência de campo são alcançadas assegurando-se que os tempos improdutivos inerentes às operações sejam mantidos ao nível mínimo (Witney, 1988). Fatores como maiores velocidades, máquinas de maior largura, talhões 
de maior comprimento, manobras de menor tempo e procedimentos de manuseio de material mais adequados contribuem ao seu alcance. Em se tratando de máquinas de colheita, os principais fatores que influenciam a eficiência são o sub-aproveitamento da capacidade das máquinas, os procedimentos inadequados de manuseio de materiais, a área e o formato de talhões, as técnicas de manobra de cabeceira, os padrões de percurso e as limitações de sistema.

Após esse período, principalmente na década de 80, o foco dos estudos voltouse ao desenvolvimento e a aplicação de modelos de simulação,. A partir dos anos 90, com o desenvolvimento das técnicas de Agricultura de Precisão, esse passou a ser o principal enfoque das pesquisas em maquinaria agrícola. Recentemente, alguns pesquisadores, utilizando-se de dados obtidos no monitoramento do rendimento de colhedoras de cereais e de um Sistema de Informações Geográficas, determinaram as suas capacidades e eficiências (Gimenez et al., 2002; Nessrallah et al., 2001). Os resultados permitiram identificar, nos talhões, unidades distintas, nas quais a capacidade variou de modo significativo, permitindo o cálculo dos custos e dos retornos financeiros diferenciados ao longo das áreas.

Nessa mesma linha de pesquisa, Grisso (2002) analisou padrões de percurso a partir de dados coletados em monitores de produtividade, durante operações de colheita, e monitores DGPS, durante operações de plantio, a fim de prover estudos de tempos e movimentos dos equipamentos. Eficiências, velocidades e tempos improdutivos foram comparados em cinco talhões de características geométricas distintas. Quando o percurso em contorno foi contrastado com o retilíneo, o nível de eficiência foi 20\% inferior. As velocidades, por sua vez, também foram inferiores para os percursos em contorno, em mais de $1,5 \mathrm{~km} \cdot \mathrm{h}^{-1}$. Mais do que o dobro do número de manobras improdutivas foi também registrado. Os resultados demonstraram que dados georeferenciados, coletados durante a realização das operações, são uma ferramenta útil na tomada de decisão e gerenciamento da maquinaria. 


\subsubsection{Custos associados}

Alvarenga \& Novaes (1999) definem custo como o somatório dos insumos necessários à realização de um serviço ou operação, avaliado monetariamente. Para Martins (1996), a noção de custo está diretamente ligada à produção de bens ou serviços. Gasto, segundo o autor, é o sacrifício financeiro com que a entidade arca para a obtenção de um produto ou serviço. Já a noção de custo está diretamente ligada à produção de bens ou serviços. É um gasto que só é reconhecido efetivamente como tal no momento de sua utilização na fabricação de um produto ou na execução de um serviço.

Os custos operacionais de uma máquina agrícola são tipicamente agrupados em duas categorias: fixos e variáveis. Os fixos compreendem a depreciação, os juros sobre o capital investido e os encargos de taxas, alojamento e seguros. Já os variáveis envolvem o consumo de combustível e de óleos lubrificantes, os reparos, as peças, as manutenções e o custo de mão-de-obra direta. A metodologia de cálculo é consagrada, e é apresentada por Hunt (1977), Witney (1988) e ASAE (1999a).

\subsection{Modelagem e suas aplicações em mecanização agrícola}

Caixeta Filho (2001), se referindo à conceitos básicos do processo de modelagem, relata que uma das preocupações básicas da ciência, ao longo dos tempos, diz respeito à observação, reprodução e aprimoramento de fenômenos de naturezas das mais distintas. De acordo com o autor, a partir do momento em que se considere que tais fenômenos são devidamente compreendidos, e eventualmente controláveis, haverá condições de se obter um pequeno nível de incerteza nas previsões de ocorrência de eventos correlatos.

Ortúzar \& Willumsen (1994) definem um modelo como uma representação simplificada de um evento específico do mundo real, o sistema de interesse. Segundo os autores, os modelos concentram elementos e informações que permitem a análise desse último, no enfoque abordado. Desse modo, por meio dos processos de simulação e de modelagem, novos conhecimentos são adquiridos e o planejamento das atividades é facilitado (Caixeta Filho, 2001). 
Modelos computacionais de simulação são normalmente aplicados na análise e otimização de sistemas agrícolas mecanizados. Parmar et al. (1996), em concordância com Hunt (1977), citam que o objetivo final do gerenciamento da maquinaria é elevar os retornos financeiros das atividades agrícolas, por meio da seleção e do gerenciamento dos equipamentos por ela utilizados. Segundo os autores, uma vez que são muitas as variáveis envolvidas nessa complexa tarefa, modelos de simulação são freqüentemente utilizados como ferramenta de auxilio às requeridas tomadas de decisão. Outro fator que subsidia o apoio à modelagem é a utilização crescente de microcomputadores como uma das ferramentas de gerencia mais importantes das empresas. De fato, diversos programas foram desenvolvidos a fim de auxiliar os tomadores de decisão no gerenciamento mais efetivo e eficiente das operações agrícolas (Chen et al., 1992; Lal et al., 1992; Milan, 1992; Parmar et al., 1996; Dahab et al., 1998; Tachibana et al., 1999). Nesses, diversas técnicas foram empregadas na modelagem dos sistemas. Dentre as mais utilizadas, destacam-se a simulação e a programação linear.

Um dos estudos clássicos na área é o modelo elaborado por Burrows \& Siemens (1974). O objetivo dos autores foi desenvolver uma ferramenta de cunho educacional e que auxiliasse a tomada de decisão por parte dos produtores no momento de aquisição da maquinaria. No estudo, foram focadas as fazendas norte-americanas produtoras de milho e de soja. A maquinaria ótima foi determinada para áreas de 81 à 810 ha, sendo a metodologia baseada nos custos indiretos, ou de pontualidade. Dentre os resultados oferecidos, estão o tamanho de maquinaria que proporciona a minimização dos custos operacionais, o cronograma das operações, as áreas envolvidas, a utilização anual dos equipamentos, o custo de mão-de-obra e o custeio itimizado das operações.

Ainda na década de 70, muitos modelos foram desenvolvidos focando os sistemas agrícolas mecanizados, a sua maioria nos Estados Unidos. Citam-se Hugues \& Holtman (1976) e Singh \& Holtman (1979), ambos abordando a seleção otimizada de maquinaria. Contudo, foi na década de 80 que ocorreu a maior parte dos trabalhos na área, em função do chamado “boom” dos computadores. Edwards \& Boehlhe (1980) trabalharam com o dimensionamento dos equipamentos, Al-Soboh et al. (1983), Rotz et 
al. (1983) e Huan-Wen \& Hunt (1985) com a seleção, Ozkan \& Edwards (1986) com o planejamento e Ozkan \& Holmes (1990) com os seus custos de oportunidade.

“TERMS”, um modelo computacional interativo a ser utilizado em simulações de campo, foi desenvolvido por Colvin et al. (1989) com o objetivo de aprimorar a acurácia das estimativas de capacidade de campo e de consumo de combustível. O modelo utiliza referenciais teóricos básicos, equações empíricas sobre força de tração e consumo e um algoritmo de cálculo de tempo de manobra. Simultaneamente, o modelo alia o resultado das rotinas descritas às características de área, de formato e de declividade dos talhões. A validação das predições demonstrou elevado coeficiente de correlação dos resultados com dados reais armazenados em quatro anos de operação da maquinaria.

Uma das grandes vantagens em utilizar recursos computacionais na modelagem de sistemas, sejam eles de qual natureza forem, é que estes se constituem em ferramentas valiosas na simulação do seu funcionamento e de seus componentes. A quantidade de variáveis e informações, e a relativa complexidade das interações entre elas, representam a razão principal de desenvolver modelos de simulação na forma computacional (Milan, 1992).

Esse foi um dos principais enfoques dos trabalhos a partir de 90: a simulação de sistemas. Nessa linha, o "COTSIM”, um modelo de simulação de sistemas de colheita e transporte de algodão foi desenvolvido por Chen et al. (1992). Os resultados sugeriram que essa última afeta a safra e o retorno econômico. Outro resultado de interesse demonstrou que o número de transbordos deve ser selecionado de modo que o tempo de descarga da colhedora não seja excessivo. Por simulações sucessivas, pode-se alocar as áreas ótimas para cada grupo de maturação, determinar a melhor data inicial de colheita e selecionar os equipamentos que proporcionam o sistema de melhor desempenho.

Milan (1992), estudando o sistema típico de produção de cana-de-açúcar no Estado de São Paulo, o modelou com base em seus subsistemas e suas interações. O objetivo do autor foi identificar fatores críticos e estratégias relacionadas com os equipamentos utilizados. As análises de sensibilidade desenvolvidas em três diferentes 
situações, ou cenários, mostraram que o preço inicial dos caminhões e as suas capacidades de carga foram os fatores que mais influenciaram o custo de produção.

Haffar (1992), utilizando-se também da elaboração de cenários, comparou três distintos sistemas mecanizados de colheita de pepino. O modelo “CUCHARV, além de fornecer subsídios à tomada de decisão no agendamento dos dias de colheita, calcula os valores de produção e de produtividade, os custos diários e as receitas a serem obtidas.

Sogaard \& Sorensen (1996) desenvolveram um modelo computacional não linear para ser utilizado como ferramenta de auxilio à tomada de decisão na análise e seleção de sistemas mecanizados. Os resultados fornecem, a partir das informações de entrada do usuário, o tamanho necessário dos implementos, a potência requerida e o número de conjuntos, bem como suas capacidades efetivas e eficiências.

Hansen et al. (2002) selecionaram a simulação como o meio apropriado para a análise do ciclo produtivo de colheita e transporte da cultura da cana-de-açúcar, dos talhões às unidades de moagem. O objetivo foi representar distintos sistemas, dentre eles os de corte manual e mecanizado, verificando estratégias que possibilitassem reduzir os atrasos na operação, elevando assim o nível de sucrose na matéria-prima, e o número de veículos requerido. As simulações demonstraram que a etapa de colheita é decisiva no desempenho do processo como um todo. Para os autores, o uso da técnica de simulação tornou possível modelar um sistema complexo. Todos os componentes foram integrados, de modo que alcançou-se ma visão holística do problema, atendendo os interesses tanto de produtores quanto de usineiros.

No Brasil, a grande maioria dos trabalhos na área foi realizada a partir da década de 90. De fato, essa foi a época na qual as aplicações computacionais se iniciaram no país. A maioria ocorreu em universidades e instituições de pesquisa, ao nível de pós-graduação. Lopes \& Milan (1998), em seu trabalho, identificaram os parâmetros de maior influência sobre o custo de carregamento, reboque e transporte de cana-de-açúcar. Os autores concluíram que a mão-de-obra foi o fator cujo aumento mais onera o sistema de transporte, enquanto a carga útil dos veículos foi aquele cujo aumento mais o reduz. 
Barbosa et al. (1998) modelaram sistemas mecanizados de seis distintas culturas, visando identificar os fatores críticos de contribuição ao acréscimo dos custos e elaborar estratégias para sua minimização. Dentre os resultados obtidos, os mais significativos foram o valor de aquisição e o tempo de utilização dos equipamentos. Tachibana et al. (1999), avaliando sistemas mecanizados para a cultura do limão siciliano, concluíram que o aumento da capacidade do tanque dos pulverizadores eleva a capacidade potencial, bem como reduz o custo operacional e o dimensionamento da frota.

Veiga (2000) desenvolveu um modelo empírico para a seleção e cálculo dos custos de sistemas mecanizados para a cultura da soja, baseado na época de plantio. $\mathrm{O}$ modelo leva em consideração o custo da pontualidade de semeadura, sendo este o fator adotado pela autora na busca da redução dos custos, através da elaboração de distintos cenários.

Tachibana et al. (2002) simulou a operação de sistemas mecanizados na aplicação de defensivos em culturas perenes, visando a redução de custo. O autor pôde observar que fatores de maior peso no custo da maquinaria foram o volume de calda, a velocidade de aplicação e o valor de aquisição dos equipamentos.

Em um dos mais recentes trabalhos na área, Fey et al. (2002), utilizando-se da técnica de programação linear, aplicada em um sistema agrícola, buscou otimizar a rentabilidade da produção. As culturas consorciadas foram soja, milho, feijão da seca, trigo e mandioca. Além do maior retorno econômico propiciado, de 9,8\%, os autores obtiveram ainda os benefícios inerentes ao planejamento adequado da rotação e manejo das culturas.

\subsection{Custeio baseado em atividades}

Martins (1996), em um retrospecto histórico a cerca de terminologias pertinentes à contabilidade, relata que, em se tratando de custos, essa é uma atividade relativamente recente. Até a Revolução Industrial, práticamente só existia a contabilidade financeira, ou geral. Com o advento dessa última, no século XVIII, entretanto, a tarefa contábil se tornara mais complexa. Agora, para levantamento do 
balanço e apuração dos resultados, não haviam mais tão facilmente dados que possibilitassem a atribuição de valores aos estoques. Surgem, assim, o que hoje são chamados sistemas de custeio tradicionais.

Novaes (2001) ressalta que embora a análise de custos tenha sido um elemento importante na gestão das empresas, foi somente nos últimos anos que ela tomou uma feição diferente, mais sofisticada. Entre as causas, o autor cita o crescimento virtuoso dos custos de administração. Antes, logo após a Segunda Guerra, o custo direto de mãode-obra e de materiais representava mais de $90 \%$ do custo de um produto, com os custos indiretos totalizando os restantes $10 \%$. Hoje, as despesas correspondentes aos custos operacionais fixos e de administração, podem simbolizar até 50\% do custo de produção.

Os sistemas tradicionais promovem a alocação dos custos indiretos através de rateios arbitrários e/ou subjetivos (Morais, 2003). Uma vez que esses não mensuram o consumo real dos recursos caso as atividades produtivas não se correlacionem com o volume produzido, a informação de custo se torna distorcida (Rocha \& Mühlen, 2001). Segundo Cokins (1996), os sistemas tradicionais não oferecem indicadores que reflitam adequadamente os recursos e os processos, pois falta, a eles, a ligação entre o recurso consumido e a atividade que o exigiu. Assim, esses deixam de revelar as causas dos seus custos e as oportunidades de melhoria. O sistema de custos baseado em atividades, ou Activity-Based Costing (ABC), foi desenvolvido objetivando oferecer um tratamento diferenciado aos custos indiretos, não mais por rateios arbitrários, mas pelo custeamento das atividades (Morais, 2003).

Os fundamentos teóricos do custeio ABC têm apresentado resultados satisfatórios em diversas aplicações em industrias e empresas de serviços. O objetivo básico do método, segundo Novaes (2001), é quebrar a caixa-preta dos custos indiretos, inclusive os de administração, e dos custos operacionais fixos, ligando-os diretamente aos clientes, produtos e pedidos. De uma forma geral, os objetivos do método ABC são (i) reduzir ou eliminar custos que adicionam pouco valor ao produto ou serviço; (ii) aumentar a eficiência e das atividades que adicionam valor; (iii) encontrar as raízes que causam os problemas e (iv) remover distorções causadas por falhas na interpretação das relações entre causas e efeitos, levando à alocações errôneas de custo (Cokins, 1996). 
Um dos objetivos do método $\mathrm{ABC}$ é ir mais fundo na explicação da composição dos custos da empresa e da cadeia de suprimento. O método tem, como meta básica, explicitar as relações de causa e efeito entre os custos de natureza diversa com os recursos utilizados na produção dos bens e serviços, com as atividades necessárias para produzi-los e com os produtos finais dos seus processos. Para Ostrenga et al. (1993), o método tem, como principio, alocar custos que reflitam, ou espelhem, a dinâmica fisico-operacional da empresa.

O ABC assume, por pressuposto, que os recursos da empresa são consumidos por suas atividades, e não pelos produtos que ela fabrica (Nakagawa, 1991). De uma maneira geral, os recursos da empresa são consumidos na realização de atividades diversas. Essas são executadas para gerar produtos ou serviços que, por sua vez, vão ser alocados à objetos diversos. Tem-se assim (Novaes, 2001): consumo de recurso pelas atividades, relacionamento das atividades com os diversos produtos ou serviços e alocação dos custos aos clientes que consomem produtos ou serviços.

Para Nakagawa (1994), embora suficiente simples, esse pressuposto tem contribuído para sensível melhoria da tradicional metodologia de análise de custos. Seu objetivo é o de rastrear as atividades mais relevantes e identificar as mais diversas rotas de consumo dos recursos da empresa.

\subsubsection{Eventos, transações e atividades}

Nakagawa (1994) define a atividade como um processo que combina, de forma adequada, pessoas, tecnologias, materiais, métodos e o seu ambiente, tendo como objetivo a produção de produtos e/ou prestação de serviços. A atividade descreve, basicamente, a maneira como uma empresa utiliza seu tempo e seus recursos a fim de cumprir sua missão, objetivos e metas. Seu principal objetivo é converter recursos (materiais, mão-de-obra e tecnologia, entre outros) em produtos ou serviços.

Toda atividade é originada de um evento que, por sua vez, gera um transação, levando finalmente à realização da primeira. Os eventos indicam as ações da empresa. Um operador logístico pode oferecer, como um de seus serviços, por exemplo, a coleta de mercadoria para seus clientes. Esse é um evento. Em um determinado momento, um 
funcionário do cliente solicita o recolhimento da mercadoria, fornecendo o local da coleta e a quantidade. Foi estabelecida então uma transação. Mais tarde, um veículo do operador logístico é alocado para realizar a coleta, executando assim uma atividade.

Para processar uma atividade, ocorre o consumo de diversos tipos de recursos. Os direcionadores são os fatores que determinam ou influenciam o consumo de recursos pelos atividades, e dessas para os produtos. Novaes (2001) entende as relações entre os recursos e as atividades, e entre as atividades e os objetos, como um corte vertical no processo acima apresentado, conforme mostra a Figura 3. Torna-se importante ressaltar que o que desencadeia o consumo dos recursos é o desempenho das atividades. Portanto, esse merece ser observado e analisado cuidadosamente, a fim de que possam ser analisadas aquelas que adicionam e aquelas que não adicionam nenhum valor aos produtos (Nakagawa, 1991). Para o autor, as atividades são desempenhadas em resposta à necessidade de desenhar, produzir, comercializar e distribuir os produtos de acordo com a real demanda dos clientes. Assim, são elas que devem fazer parte dos objetivos de observação, coleta, registro e análise de um sistema de custeio.

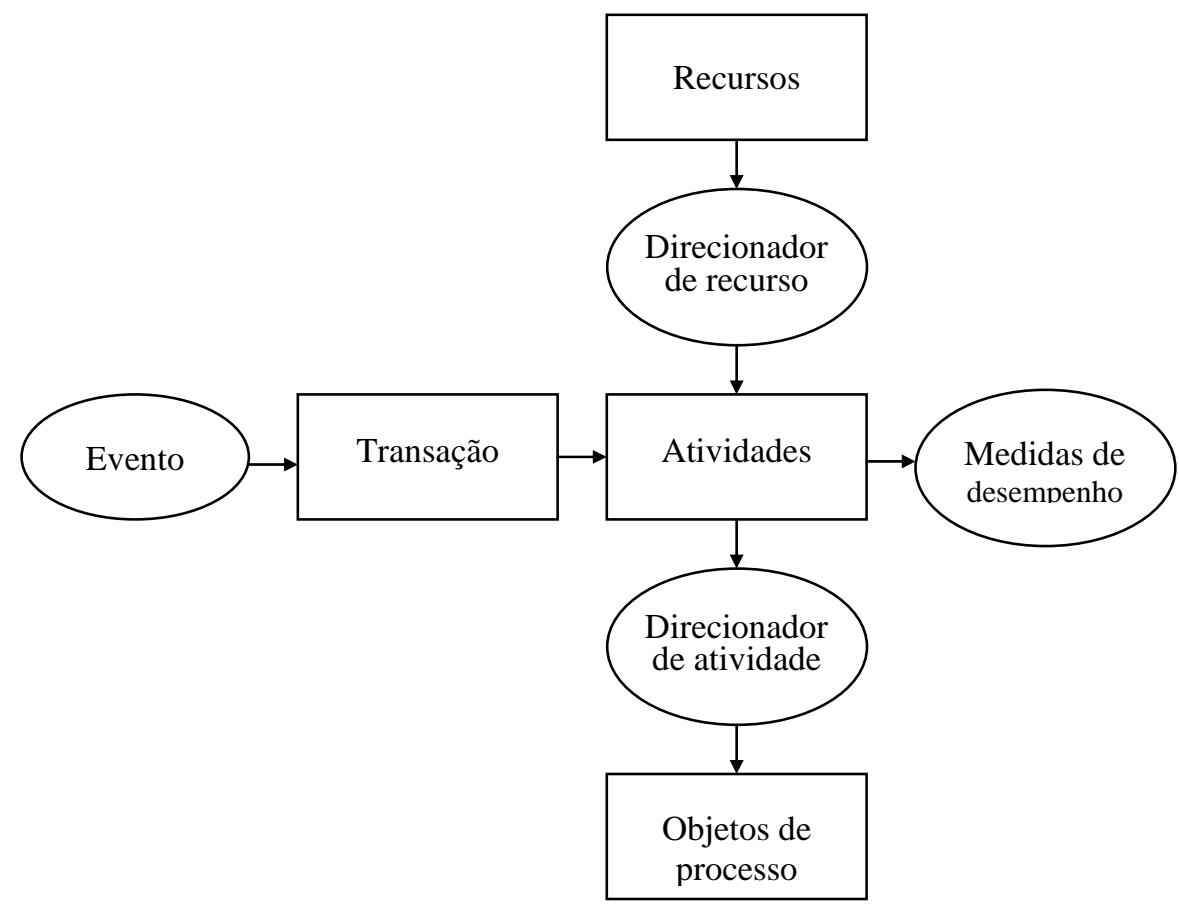

Figura 3 - As atividades de custo como processamento de uma transação, na interseção de dois cortes. Adaptado de Novaes (2001) 


\subsubsection{Direcionadores}

O direcionador de custos é, segundo Martins (1996), o fator que determina o consumo de recursos de por uma atividade. Como as atividades exigem recursos para que sejam realizadas, deduz-se que o direcionador é a verdadeira causa dos custos. Ele deve refletir a causa básica da atividade e, conseqüentemente, de seus custos.

Basicamente, o relacionamento entre os recursos utilizados pela empresa, as atividades e objetos das ações da empresa, sejam eles produtos, serviços ou clientes, se apóia em um conceito triplo, de acordo com Novaes (2001): (i) as atividades de uma empresa consomem recursos físicos e operacionais de vários tipos. A relação entre recursos e atividades é feita por direcionadores de recurso; (ii) as atividades podem ser relacionadas, de forma direta ou indireta, com custos e (iii) os objetos das ações da empresa podem ser relacionados às atividades através dos direcionadores de atividades.

Ostrenga et al. (1993) descreve que o primeiro passo importante na aplicação do $A B C$ é organizar as inter-relações para que essas tenham uma orientação para processos/atividades. Uma vez concluída essa análise preliminar, estabelece-se as relações entre os recursos utilizados e as atividades, utilizando-se, para tanto, bases específicas de alocação de custo à cada uma delas. Para Nakagawa (1994), por ser realizado dessa forma, o método $\mathrm{ABC}$ permite mensurar com mais propriedade a quantidade de recursos consumidos por cada produto durante o processo que o origina. $\mathrm{O}$ autor destaca ainda, contudo, que o $\mathrm{ABC}$ não se diferencia do sistema tradicional, baseado em volume, apenas pela mudança das bases de alocação dos custos. A diferença principal se encontra na identificação que faz dos custos por atividades e da maneira como aloca os custos aos produtos através de um maior número de bases.

Novaes (2001) considera um exemplo que facilita o entendimento desse conceito. Na Figura 4, são mostrados três recursos: combustível, veículos e mão-de-obra para carga/descarga, e duas atividades: entrega dos produtos aos clientes e carregamento dos veículos de distribuição. O consumo de combustível está relacionado com a atividade 1, mas não está ligado à 2, pois os veículos permanecem parados enquanto são carregados. Entretanto, mesmo parados, esses estão sendo utilizados, pois seu uso fica bloqueado para realizar outras atividades. Já que esses são utilizados nas duas 
atividades, o seu custo de capital desse deve ser ligado a ambas. O pessoal de operação, por sua vez, está relacionado apenas à atividade 2.

Segundo o autor, para cada relação recurso/atividade, deve-se selecionar um direcionador de recurso adequado, escolhido cuidadosamente entre os possíveis fatores explicativos, de forma a melhor representar a relação de causa e efeito específica para cada caso. No exemplo citado, tanto para o recurso veículos, como para o custo de mãode-obra, o direcionador mais adequado é o tempo de operação da atividade. Por outro lado, o combustível está diretamente relacionado com a quilometragem percorrida no trajeto da distribuição. A atividade entrega dos produtos aos clientes utiliza os recursos 1 e 2, mas não o 3.

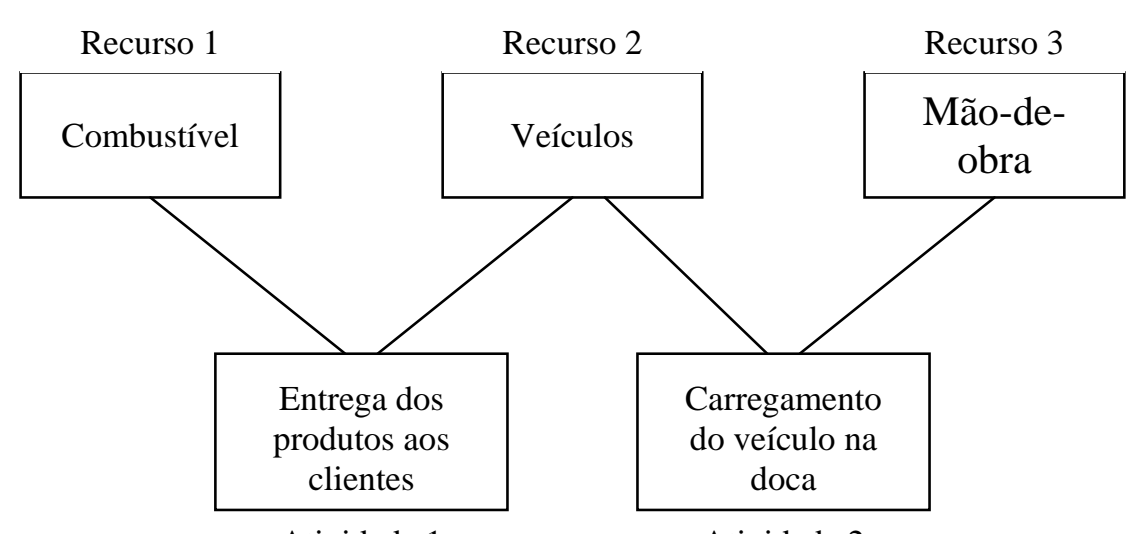

Atividade 1

Atividade 2

Figura 4 - Relação entre os recursos e as atividades de custo

Adaptado de Novaes (2001)

\subsubsection{Tipos de direcionadores}

Normalmente, os direcionadores no método ABC são de três tipos (Novaes, 2001): direcionadores de transação, direcionadores de duração e direcionadores de intensidade.

Os direcionadores de transação se referem ao número de operações repetitivas. Incluem-se nessa categoria o número de set ups de uma máquina, o número de pedidos, o número de veículos descarregados, entre outros. Segundo o autor, esse tipo de 
direcionador pode ser utilizado quando todos os outputs da operação imprimem, mais ou menos, o mesmo nível de esforço sobre a atividade.

Já os direcionadores de duração estão relacionados com o tempo de execução da atividade. As situações típicas que requerem sua utilização são aquelas nas quais ocorrem variações apreciáveis no tempo de execução de uma certa atividade, em função do sistema utilizado ou do nível de eficiência em sua realização.

Os direcionadores de intensidade consideram diretamente a quantidade de recursos necessária para realizar uma determinada atividade. Embora sejam os mais precisos, uma vez que refletem melhor o consumo dos recursos de produção, são os que consomem mais tempo e homens por hora para serem levantados. Exemplificando, temse o momento de transporte, mensurado em ton. $\mathrm{km}^{-1}$. 


\section{MATERIAL E MÉTODOS}

O estudo e a avaliação das estratégias de colheita foram realizados por meio de seis distintas análises. Na primeira, foram incluídas as etapas de definição do problema inicial a ser modelado, de desenvolvimento do algoritmo e de sua tradução para a linguagem de programação. Na segunda, procedeu-se a análise do programa de simulação desenvolvido, por meio das etapas de verificação da rotina e de validação dos resultados por ele oferecidos. A terceira análise, a de sensibilidade, objetivou identificar os parâmetros que possuem as maiores participações na formação dos custos de sistema. A quarta foi focada no entendimento das estruturas de custo. Por meio dessa, buscou-se propiciar um melhor entendimento da formação dos custos da colheita mecanizada e de seus subsistemas. A quinta análise foi focada no desempenho operacional da maquinaria. O objetivo foi buscar o entendimento de como se comportam e como se inter-relacionam os principais parâmetros determinantes de seu desempenho e custo. Por último, a sexta análise constituiu efetivamente a elaboração das estratégias de colheita, como foco no planejamento do prazo de retirada de produção e no dimensionamento e configuração da frota. As metodologias empregadas no decorrer das análises são descritas a seguir.

\subsection{Problema inicial e sistemas de colheita}

Como sistema de colheita definiu-se, nesse estudo, o conjunto de operações, de procedimentos e de eventos necessário à retirada e ao transporte da safra, dos talhões de realização da colheita ao local de recepção da produção. Embora represente uma análise igualmente importante, a logística envolvida no transporte dos grãos em um escopo externo à propriedade, tal como aquela aplicada na distribuição física dos produtos aos armazéns secundários, aos canais de escoamento e aos centros de consumo, não foi 
abordada. O problema inicial, base de fundamento das análises efetuadas, é apresentado pela Figura 5.

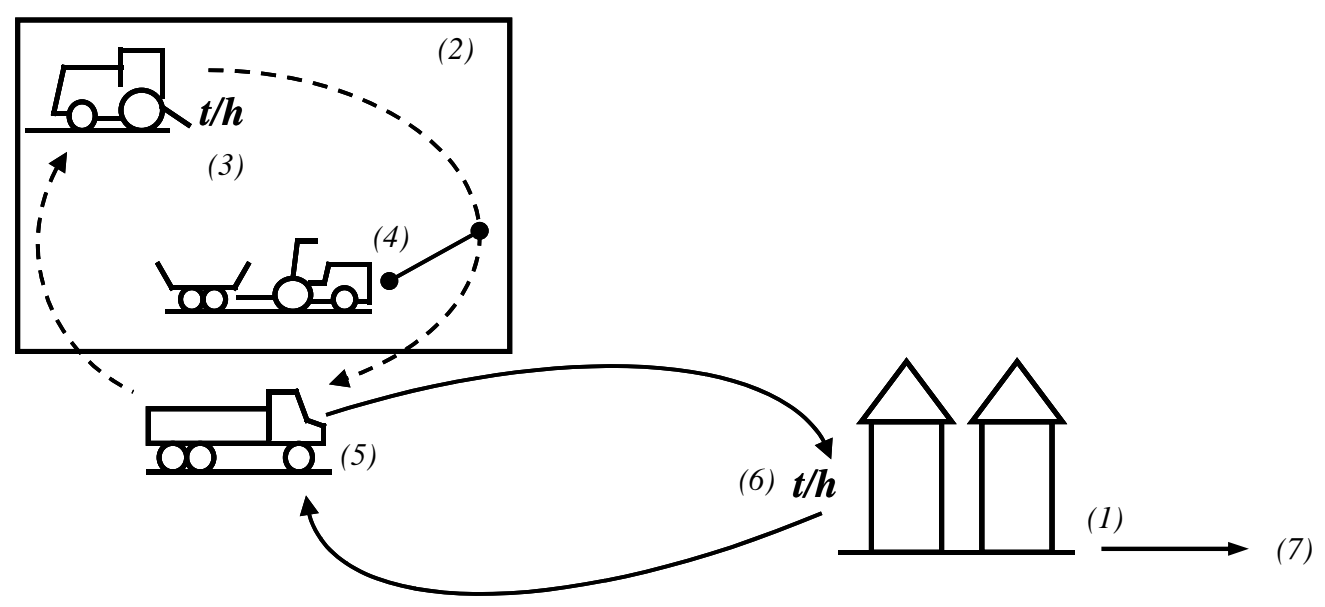

Figura 5 - Problema inicial

Segundo a abordagem empregada, a unidade de recepção (1) é que dita a taxa de produção a ser retirada dos talhões (2). A colheita (3) possui, como função, suprir a demanda ao longo da safra. A O transbordo (4) e o transporte (5) operam em associação com a colheita, sob a mesma taxa de retirada (6). A produção precisa ser deslocada dos talhões à unidade de recepção da empresa ou ao destino final (7) sem atraso. A distância torna-se, dessa forma, outro parâmetro a ser considerado. As locações dos talhões podem ter influência nas necessidades de transporte. De modo semelhante, uma vez que os equipamentos operam em associação, o desempenho de uns pode afetar os dos outros.

O estudo foi focado em três sistemas. Suas distinções ocorrem pela utilização ou não de carretas de transbordo e pela forma de descarregamento das colhedoras, em movimento ou paradas. Dessas, apenas as combinadas automotrizes foram enfocadas nas simulações. Considerou-se, também, que todos os sistemas utilizam veículos, sejam eles caminhões ou carretas, no transporte final da produção dos talhões às unidades de recepção. Além disso, considerou-se que esses sempre se posicionam nos limites, em estradas de acesso ou em carreadores internos aos talhões, e que permanecem parados enquanto aguardam a carga ser completada. 


\subsection{Simplificações}

Em processos de modelagem, um ponto crítico a ser estabelecido por ocasião do desenvolvimento do modelo é o quão próximo da realidade esse se posicionará. O nível de simplificação à ele imposto, por ocasião de sua confecção, é o que determina o seu grau de complexidade.

Uma vez que objetivou-se o enfoque, apenas ao nível macro, dos sistemas de colheita, algumas simplificações fizeram-se necessárias. As principais foram: (i) todas as frotas, sejam elas de colhedoras, de transbordos ou de veículos foram consideradas ao nível homogêneo, sendo compostas por um único modelo de máquina; (ii) considerar a retirada de produção função da capacidade de recebimento da unidade de recepção; (iii) considerar o descarregamento das colhedoras, em cada simulação, ocorrendo sempre a uma distância constante do ponto de posicionamento dos veículos e; (iv) considerar os talhões como sendo uniformes em relação à variedade e à produtividade.

\subsection{Algoritmo proposto}

O algoritmo foi elaborado de forma a permitir a análise dos sistemas como um processo completo. Para que as operações, os procedimentos, os eventos e as decisões que os compõem tivessem suas características e suas inter-relações detalhadas, quatro subsistemas foram criados. Eles receberam as denominações de Agronomia, Colheita, Transbordo e Transporte, e formaram a base estrutural de elaboração do algoritmo. Um quinto, Economia, foi criado a fim de agrupar os cálculos dos seus custos operacionais. A Figura 6 os apresenta e ilustra as suas regiões de interface. Na seqüência, são listadas as suas áreas de atuação.

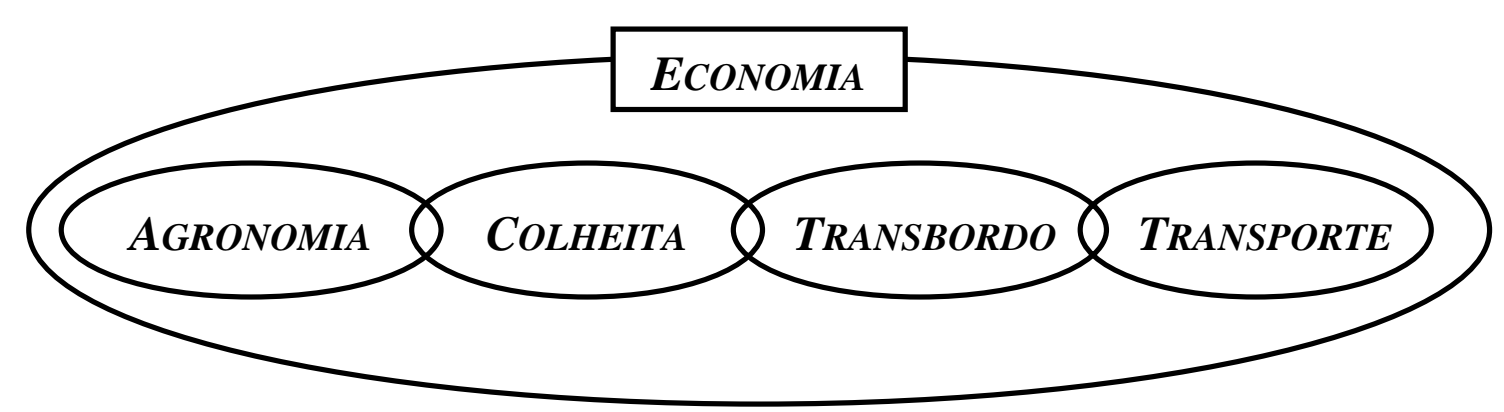

Figura 6 - Subsistemas utilizados na elaboração do algoritmo e confecção do modelo 
- Agronomia: características do sistema e decisões gerenciais;

- Colheita: retirada de produção da cultura;

- Transbordo: transporte da produção do interior dos talhões, onde estão localizadas as colhedoras, aos seus limites, onde estão localizados os veículos de transporte;

- Transporte: transporte da produção dos talhões à unidade de recepção;

- Economia: contabilidade de custos.

A Figura 7 apresenta o esquema estrutural do algoritmo proposto. Os dados de entrada (01), em conjunto com as decisões gerenciais dos usuários (02) são analisados pelo algoritmo Agronomia (03), fornecendo assim a base para a confecção do balanço de colheita (04). O balanço de colheita é uma tabela, gerada pelo programa em um banco de dados, que relaciona, para cada dia ou semana efetivo de colheita, a identificação dos talhões e as demandas das unidades, bem como as áreas e as produções a serem colhidas pela maquinaria.

A época de realização (05), o tempo disponível (06), as características dos equipamentos (07) e a locação dos talhões (08), juntamente com o balanço de colheita, são processados pelos algoritmos Colheita (09), Transbordo (10) e Transporte (11), fornecendo a base para a confecção dos balanços de maquinaria (12) e de desempenho (13). O balanço de maquinaria, tal como o de colheita, é um tabela pertencente à um banco de dados. Nela encontram-se registrados o número de equipamentos necessário, as horas-máquina trabalhadas, os quilômetros percorridos e o combustível consumido na operação. Por sua vez, o balanço de desempenho armazena os dados operacionais mais relevantes à avaliação do desempenho da maquinaria. Ambos são gerados para cada dia ou semana indicado no balanço de colheita. Posteriormente, os registros são processados pela rotina Custos (14), em conjunto com outros parâmetros de ordem econômica, como a taxa de juros, a vida útil dos equipamentos e as taxas de reparo e manutenção, na qual são efetuados os cálculos dos custos de cada subsistema e do sistema completo (15). 


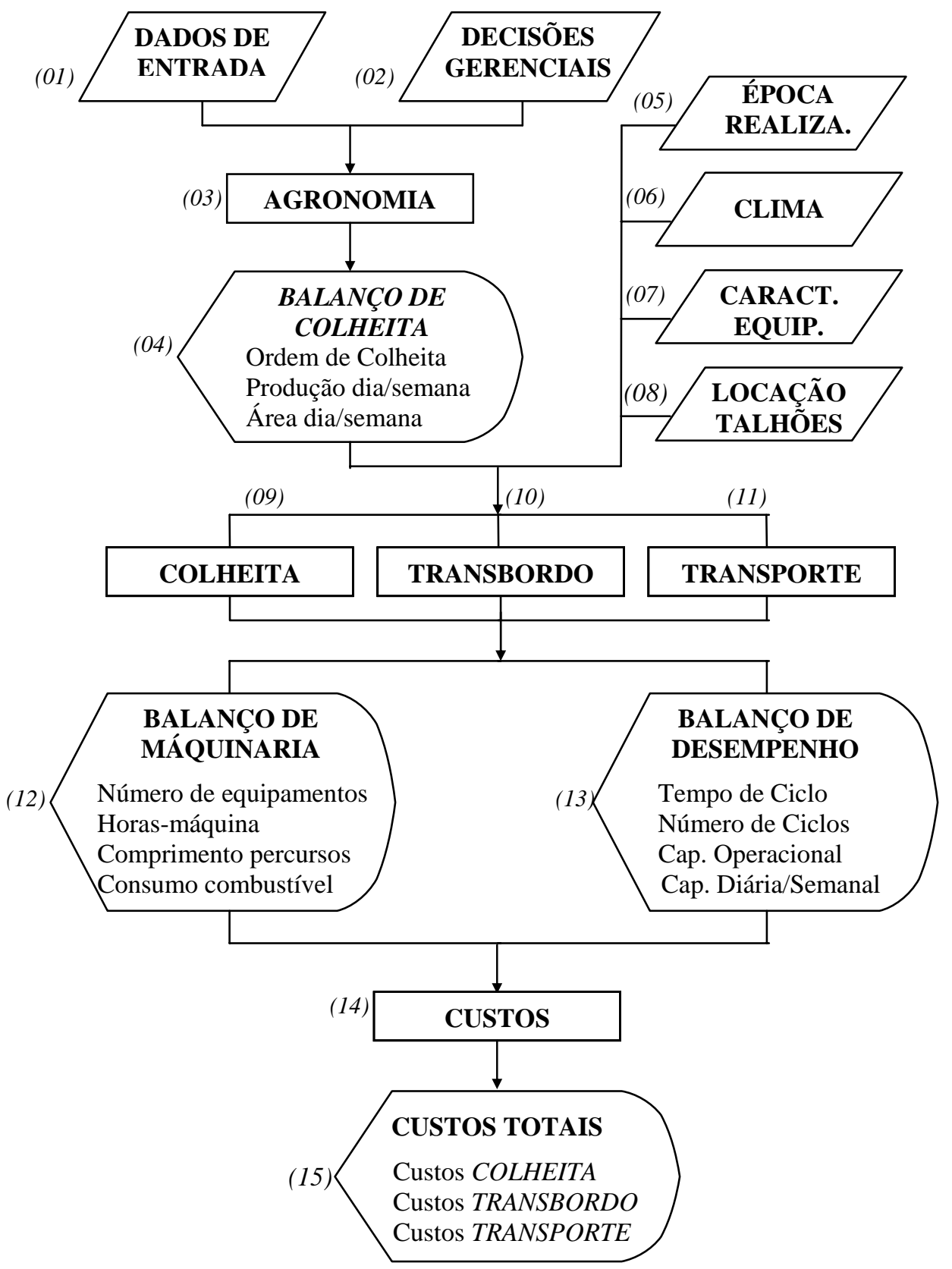

Figura 7 - Fluxograma - esquema estrutural do algoritmo proposto para o modelo

\subsection{Detalhamento e rotinas de cálculo}

Para cada um dos cinco subsistemas foi desenvolvido um algoritmo específico, representativo de seus componentes e de suas variáveis de influência. Cada um deles resultou em rotinas de programação distintas, que interagem entre si e, em conjunto, constituem a base estrutural do modelo. As principais estruturas têm seu detalhamento 
apresentado a seguir. Em conjunto, são discutidas as rotinas empregadas nos cálculos dos parâmetros de desempenho operacional da maquinaria.

\subsubsection{Agronomia}

O fluxograma do algoritmo Agronomia é apresentado pela Figura 8. O algoritmo se inicia, em cada simulação, com a definição da época de realização das atividades (01). Nessa constam as datas desejadas de inicio e término da operação. O passo seguinte consta da seleção da cultura (02) e dos talhões a serem colhidos (03). No banco de cadastro de talhões (02), estão compreendidas todas as informações relativas às suas identificações e caracterizações de ordem física e agronômica. São elas: nome, cultura, variedade, área, produtividade, produção, índice de eficiência e distância dos trechos pavimentados e não pavimentados frente à unidade de recepção. O algoritmo busca, no banco de cadastro, todos os talhões que abrigam a cultura indicada, bastando ao usuário selecionar aqueles cuja colheita é de interesse.

A partir dos dados de área e de produtividade, a produção presente em cada talhão, é registrada (04). Para o cálculo da produção total a ser colhida, transbordada e transportada, é computado o somatório das produções individuais de cada talhão (05). Em se tratando do planejamento de colheita (06), esse pode ser feito em duas bases: diária ou semanal. A base de planejamento define a forma de saída dos resultados: por dia ou por semana. Embora o balanço de desempenho seja gerado para ambos, apenas a semanal gera os balanços de custo.

A estimativa do tempo disponível (07) é feita em função do número esperado de dias secos e do número diário de horas de operação. Dois são os caminhos a serem seguidos. No primeiro, o usuário utiliza os dados climáticos disponibilizados por Mialhe (1974). O autor, por meio de dados de disponibilidade de água no solo, para fins de irrigação, relacionou o número mínimo de dias agronomicamente secos esperado para cinco localidades da zona canavieira do Estado de São Paulo. Nessa opção, o usuário indica a região de referência e a textura média dos solos dos talhões, cabendo ao modelo buscar e calcular o número de dias secos durante a época de realização informada. No segundo, o próprio usuário é quem define, para cada mês de colheita, a porcentagem de 
dias secos esperada em sua propriedade. O modelo assume que o tempo disponível à colheita, ao transbordo e ao transporte é igual, bem como que o número de dias secos, por semana, é constante ao longo dos meses.

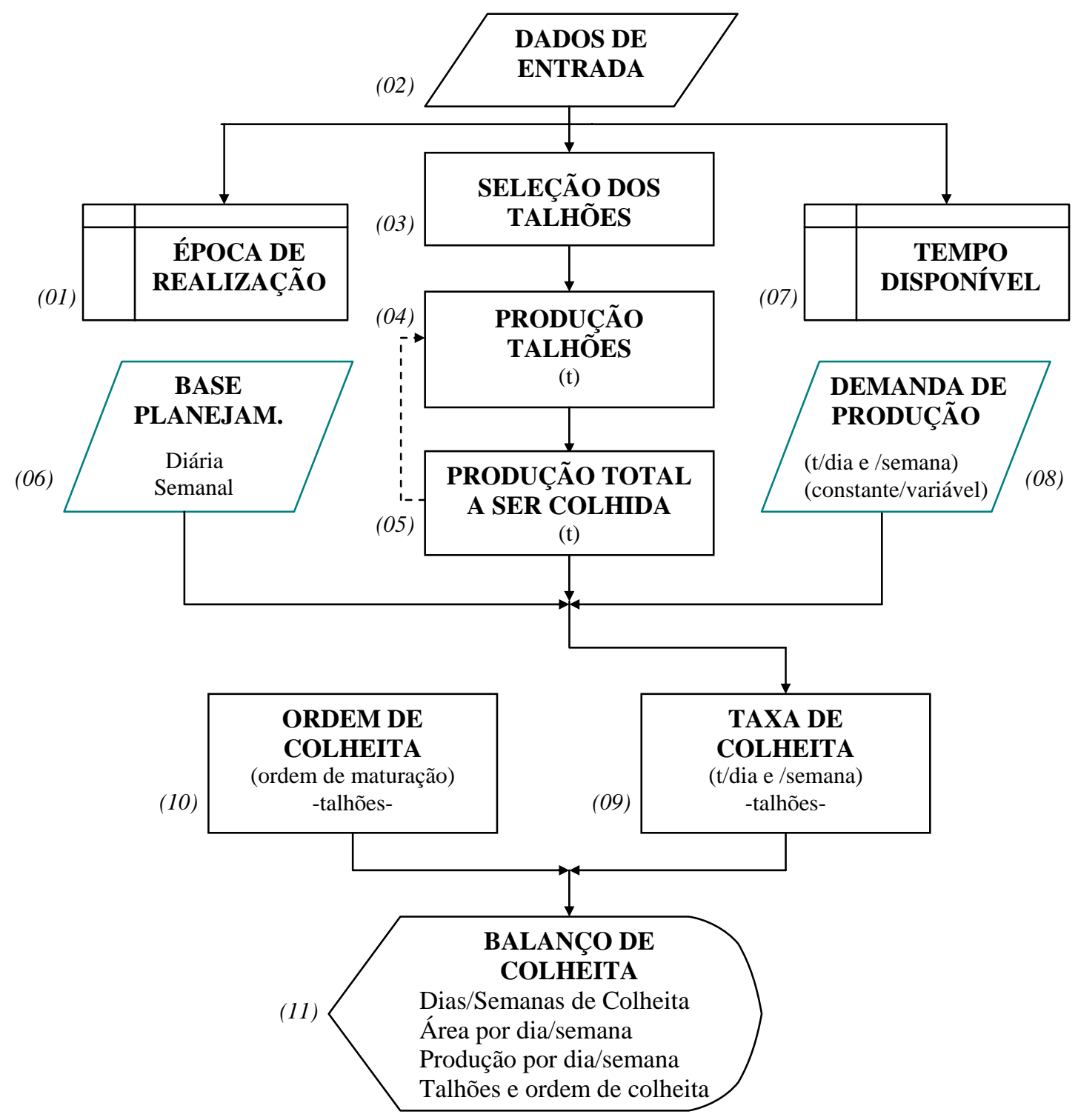

Figura 8 - Fluxograma do algoritmo Agronomia

A taxa de colheita (09), em toneladas por dia, ou por semana, é função da base de planejamento (06) e da demanda de produção (08). Essa possui base diária ou semanal, podendo ainda ser constante ou variável ao longo dos dias e semanas. 
A ordem de colheita dos talhões (10), decisão gerencial essa função do período de maturação das variedades e da locação dos talhões, em conjunto com a taxa de colheita, resulta em uma série de registros contendo a seqüência de talhões, a produção e a área a ser colhida em cada dia ou semana de colheita. Os registros são armazenados em um banco de dados, compondo a tabela base do programa - o balanço de colheita (11), ponto de partida dos três demais algoritmos.

\subsubsection{Colheita}

A Figura 9 apresenta o fluxograma representativo do algoritmo Colheita. Os dados de entrada (01), as decisões gerenciais (02) e o balanço de colheita (03) formam a base a partir da qual o algoritmo se desenvolve.

A primeira etapa é a seleção da colhedora e da plataforma a serem simuladas (04). Foram cadastradas, em um banco de dados, as máquinas atualmente disponíveis no mercado brasileiro. Nos registros desse, encontram-se armazenados, além dos dados de identificação, dados técnicos de desempenho e de custo dos equipamentos, dentre eles as capacidades e as vazões de descarga de seus tanques graneleiros, a potência nominal de seus motores, a largura das plataformas e os seus valores de aquisição. Após a seleção da máquina, faz-se a seleção do sistema de colheita (05). Três distintas possibilidades

podem ser selecionadas: i) com transbordo e descarregamento em movimento; ii) com transbordo e descarregamento parado e; iii) sem transbordo. Às três foi dado um caráter exclusivo, com o modelo permitindo a simulação apenas de um sistema por vez.

O cálculo da capacidade efetiva (06) é feito por meio da produtividade média dos talhões, da largura nominal da plataforma e da velocidade de colheita, conforme propõe Hunt (1977). Quanto à capacidade de colheita (07), esse constitui um parâmetro de desempenho criado a fim de acomodar, em conjunto com a capacidade efetiva, os três eventos que caracterizam o ciclo de atividades das colhedoras: colheita, deslocamento e descarregamento. Caso as colhedoras sejam requeridas a se deslocarem aos veículos, a cada totalização do graneleiro é computado o tempo de duração dos deslocamentos de ida e de volta aos veículos, o que reduz as suas capacidades reais de colheita. Principio análogo foi aplicado quanto aos descarregamentos que ocorrem sem movimento. 


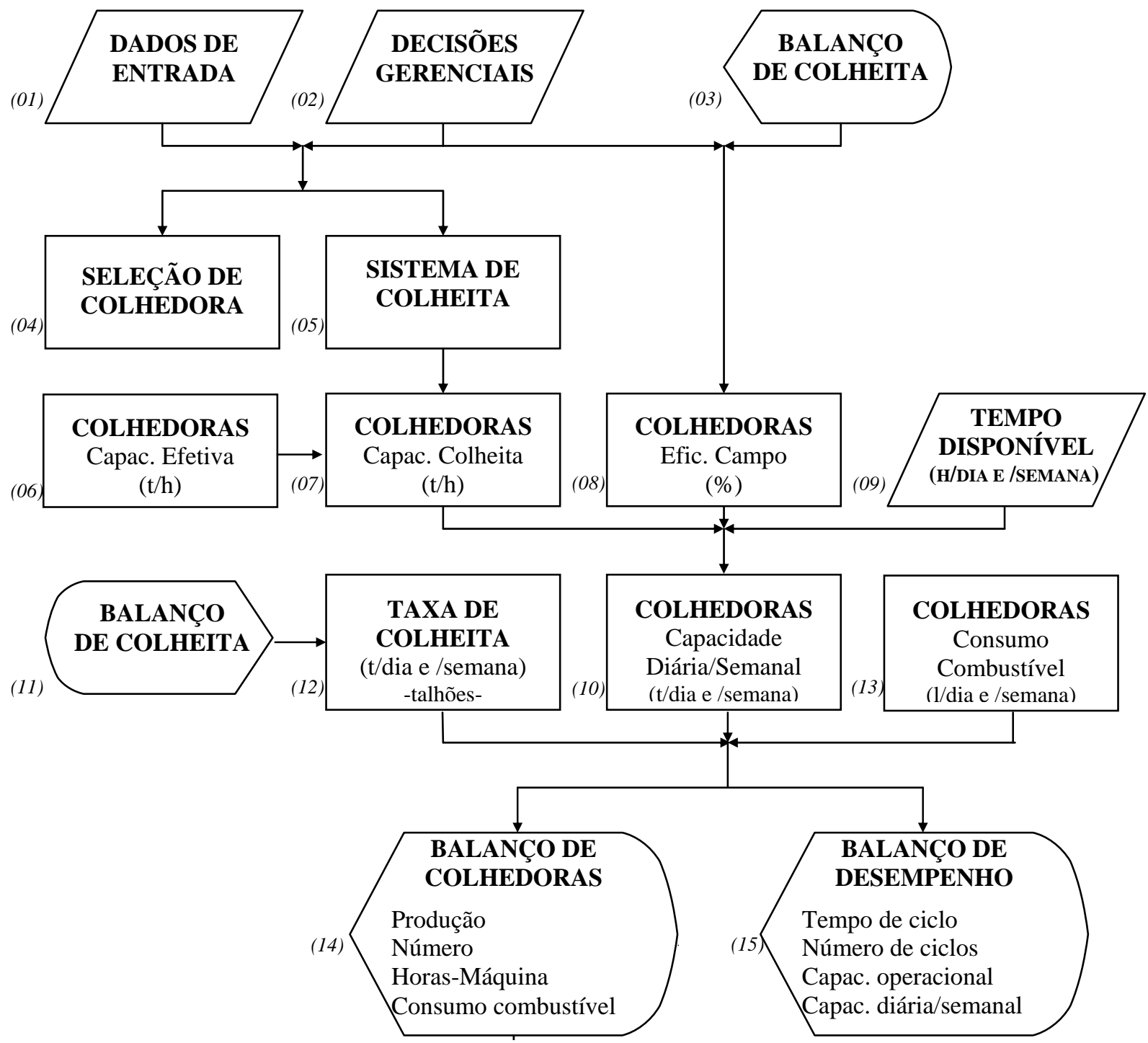

Figura 9 - Fluxograma do algoritmo Colheita

O evento Colheita foi definido como aquele no qual as colhedoras realizam efetivamente a operação para qual foram projetadas. Apenas a colheita propriamente dita, ou seja, a retirada dos grãos das plantas, pelas colhedoras, é focada. Seu cálculo é efetuado por cinco variáveis: capacidade de graneleiro (l), peso específico do produto colhido (t. $\left.\mathrm{l}^{-1}\right)$, produtividade média no talhão (t.ha $\left.{ }^{-1}\right)$, largura de plataforma (m) e velocidade de colheita $\left(\mathrm{km} . \mathrm{h}^{-1}\right)$. Já o Deslocamento representa a etapa do ciclo na qual as colhedoras, após o enchimento do tanque graneleiro, interrompem a operação e se 
deslocam aos veículos a fim de realizar o descarregamento da produção e, após realizalo, retornam ao ponto de partida para retornar à colheita. Ele é função da distância de posicionamento dos veículos e da velocidade no percurso. O Descarregamento, por sua vez, é a etapa na a produção colhida é descarregada, ao final de cada ciclo. Sua duração é função da vazão de descarga e da capacidade do graneleiro.

A capacidade diária/semanal (10), em t, é determinada pelo produto entre a capacidade de colheita (06), o tempo disponível (09), e a eficiência de campo (08). Essa última representa o percentual da capacidade de colheita aproveitado pelas colhedoras no decorrer da realização da operação. Ela é produto de três distintas eficiências, segmentadas com o intuito de representar as diferentes fontes de tempos improdutivos na operação da maquinaria: as eficiência de operação, de gerência e de talhão. O usuário indica as eficiências a serem simuladas. À ele, são apenas sugeridas as faixas de valores típicas.

Na eficiência de operação está incluída a não utilização, em sua totalidade, da largura nominal da plataforma e os tempos de manutenção preventiva e regulagem. Já a eficiência de gerência reflete a ocorrência de tempos perdidos ao longo da jornada. Estão incluídos os de manutenção corretiva, os tempos destinados à alimentação e ao descanso de operadores e os tempos perdidos em reflexo à não presença de transbordos e veículos quando e onde demandados.

A eficiência de talhão é um índice que indica a redução de eficiência em função da caracterização física de formato dos talhões. Talhões de formato irregular requerem maior número de manobras de cabeceira, reduzindo o aproveitamento da capacidade das máquinas. A eficiência de talhão é indicada pelo usuário por ocasião do cadastramento dos talhões, e é introduzida no algoritmo através do balanço de colheita (03). À ele são fornecidas as oito opções de formato sugeridas por Witney (1988). O autor sugere, para oito distintos formatos, índices de redução/incremento das eficiências. Caso o usuário não queira utilizá-los, basta indicar os de seu interesse.

O tempo disponível (09) é contabilizado em função da base de planejamento definida. Caso a opção tenha sido pela diária, esse se refere à jornada diária de trabalho. Caso tenha sido pela semanal, o tempo disponível por semana é calculado pelo produto 
entre o número de dias secos, já definido no algoritmo Agronomia, em dias, e a jornada de trabalho, em horas.

O algoritmo oferece, como resultados finais, dois balanços: o de colhedoras (14) e o de desempenho (15). O primeiro registra os dados referentes ao número de horas-máquina e de equipamentos necessário e ao consumo de combustível. Já no segundo, são agrupados os parâmetros de maior relevância à análise de desempenho. Dentre eles: a duração e o número de ciclos, as capacidades efetivas, operacionais e diárias/semanais e o tempo de operação.

O número necessário de equipamentos foi modelado pela razão entre a taxa de colheita requerida pelo sistema e a capacidade operacional de cada máquina. Um outro parâmetro que compõe o balanço de colhedoras é o seu consumo de combustível (13).

A equação de predição de consumo específico inserida na rotina foi a sugerida por Tachibana (1998) ${ }^{1}$ e utilizada por Tachibana (2000). O autor adotou uma equação empírica, obtida a partir de dados de ensaios realizados pelo CENEA (Centro Nacional de Engenharia Agrícola), entre os anos de 1980 e 1991, em tratores entre 36 e 86 kW de potência. A equação 1 a apresenta.

$C_{\text {ESPECIFICO }}=\left[\left(0,728 \cdot \frac{x}{p \cdot 0,86}\right)^{2}-\left(1,2109 \cdot \frac{x}{p \cdot 0,86}\right)+0,8054\right] \cdot 0,732$

Onde: $\mathrm{C}_{\text {ESPECífico }}=$ Consumo específico $\left(\mathrm{l} \cdot \mathrm{kW}^{-1} \cdot \mathrm{h}^{-1}\right)$;

$\mathrm{x}$ = Razão de potência (decimal);

$\mathrm{p}$ = potência nominal do motor $(\mathrm{kW})$.

De acordo com ASAE (1999a), em se tratando dos motores diesel empregados na frota agrícola, a eficiência de consumo é função do tipo de combustível e da carga demandada ao motor. Essa carga, tecnicamente denominada razão de potência, é a razão entre a potência requerida pela operação e a máxima disponível no motor. Uma vez que

${ }^{1}$ Trabalho desenvolvido na disciplina Gerenciamento de Sistemas Mecanizados, curso de mestrado em agronomia, área de concentração Máquinas Agrícolas - ESALQ/USP. 
esse é um valor extremamente variável, em função de características intrínsecas ao meio agrícola, tais como a heterogeneidade de rugosidade do solo e de declividade do relevo, um valor padrão é sugerido ao usuário, cabendo a ele decidir qual valor utilizar. Embora possa-se indicar, de forma isolada, a razão de potência de cada evento, o valor de $60 \%$ foi definido com padrão para todos os três eventos do ciclo.

O consumo de combustível em cada um dos eventos foi estimado pelo produto entre o tempo de duração de cada evento, em h, o seu consumo específico, em $1 . \mathrm{kW}^{-1} \cdot \mathrm{h}^{-1}$, e a potência nominal dos motores das colhedoras, em $\mathrm{kW}$. O consumo por ciclo foi resultado do somatório do consumo dos três eventos. Esse, multiplicado pelo número de ciclos desempenhado, em cada dia ou semana de colheita, resultou nos consumos semanais ou diários de cada máquina. Multiplicando-se esse valor pelo número necessário de colhedoras, pôde-se estimar o consumo da frota na época de realização indicada.

\subsubsection{Transbordo e transporte}

Os algoritmos Transbordo e Transporte foram elaborados a fim de suprir, respectivamente, as necessidades de movimentação da produção das colhedoras ao ponto de posicionamento dos veículos e desses às unidades de recepção. Assumiu-se que tudo que for colhido precisa ser transbordado e transportado e, assim, ambos os subsistemas possuem a missão de desempenhar o transbordo e o transporte sob a mesma taxa de retirada praticada pelas colhedoras, tanto na base diária quanto na semanal. Uma vez que a estrutura de seus algoritmos é semelhante, os dois são apresentados de forma conjunta, a partir do fluxograma do transporte (Figura 10). De forma semelhante aos demais, os algoritmos se iniciam a partir de dados de entrada (01) e de decisões gerenciais (02). A seleção da maquinaria (03) é a primeira tarefa a ser executada.

A distância a ser percorrida pelos veículos em cada viagem se refere àquela na qual os talhões que têm sua colheita agendada em cada dia ou semana de colheita se encontram da unidade de recepção (04). Essa é uma característica própria de cada talhão, cadastrada pelo algoritmo Agronomia e inserida no Transporte pelo balanço de colheita. Dois tipos de trechos fazem parte do cadastro: de terra e de asfalto. 


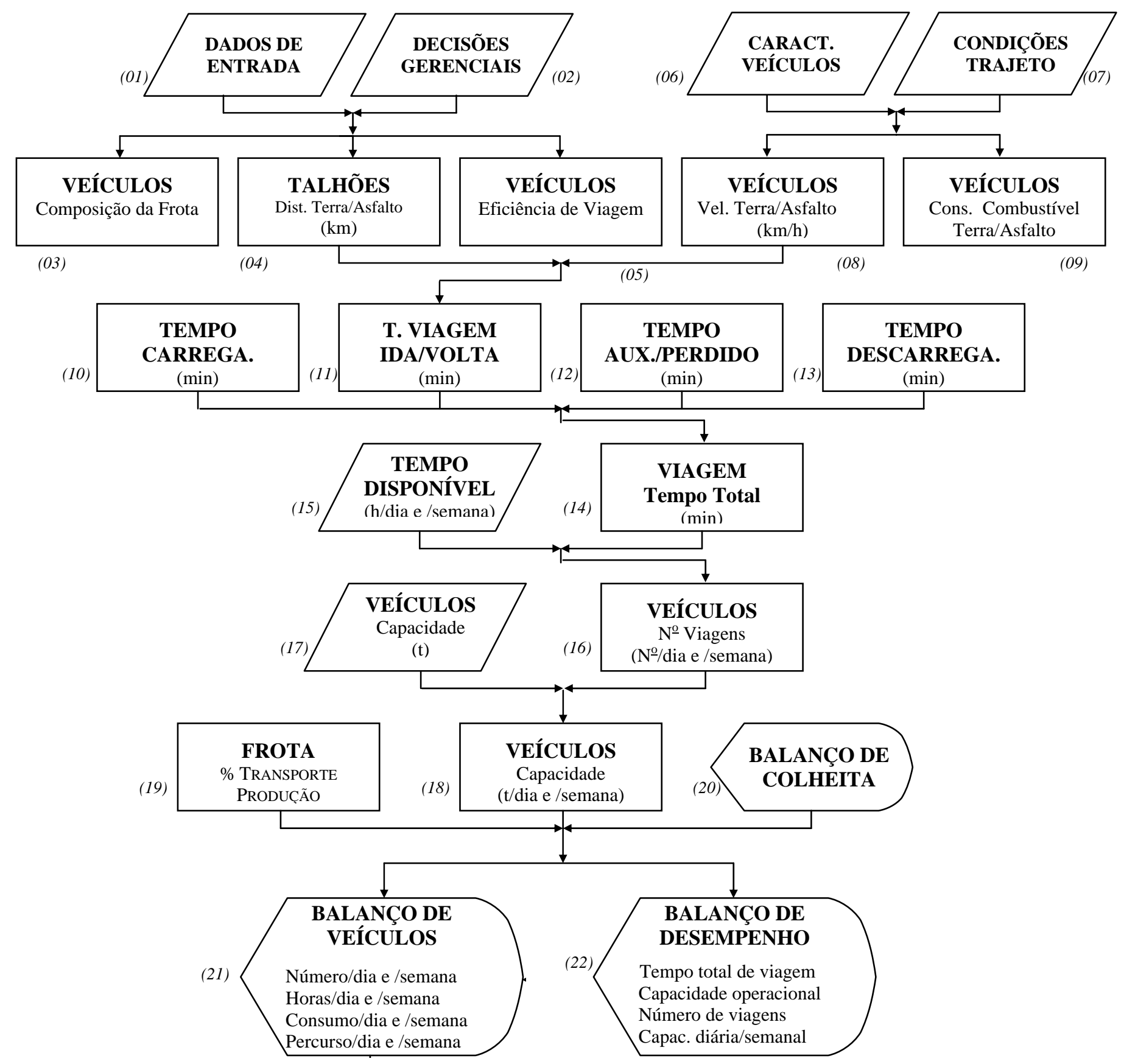

Figura 10 - Fluxograma dos algoritmos Transbordo e Transporte

A velocidade em cada trecho (08), bem como os seus respectivos consumos de (09), são calculadas em função das características dos veículos (06) e das condições de trajeto (07). Foram inseridas, na estrutura do algoritmo, equações de predição elaboradas 
por Abayanaka et al. (1976). Os autores desenvolveram equações empíricas para estimar os custos da operação de veículos em estradas rurais, em paises em desenvolvimento, a partir de dados de pesquisa desenvolvidas no Quênia. Os custos foram estimados para diferentes geometrias de estradas, condições de superfície, altitude e características de veículos. Após a estimativa da velocidade e do consumo, os resultados são informados ao usuário. Esse indica se deseja utilizá-los ou indicar os valores a serem simulados.

Os ciclos de operação dos transbordos e dos veículos foram decompostos em quatro eventos: Carregamento (10), Viagem de Ida/Volta (11), Descarregamento (12) e Tempos Auxiliares/Perdidos (13). O tempo total de viagem (14) é calculado pela razão entre o somatório dos quatro eventos principais e a eficiência gerencial (05). Essa, por sua vez, possui um caráter gerencial. Ela indica a existência de tempos perdidos nos subsistemas. Sua indicação também é uma tarefa do usuário.

Para que a capacidade de transbordo/transporte do sistema possa ser estimada, o tempo disponível (15) é dividido pelo tempo total de viagem, resultando no número de viagens efetuada por dia/semana. O número de viagens, multiplicado pela capacidade de carga dos equipamentos (17), fornece a capacidade de transbordo/transporte do sistema, em t, para cada dia/semana de colheita agendada pelo balanço de colheita (18).

De modo análogo às colhedoras, o número requerido de transbordos e veículos é calculado por meio da razão entre a taxa de retirada exigida pelo sistema, em toneladas por hora, e a capacidade operacional de cada máquina. Esse é o primeiro parâmetro a ser armazenado pelo balanço de veículos (21). Os demais são o número de horas-máquina necessário, o consumo total de combustível e a distância total percorrida. Os parâmetros operacionais de maior relevância são armazenados no balanço de desempenho (22). São eles o tempo total de viagem, o tempo de ciclo, a capacidade operacional por máquina, o número efetuado de viagens e a capacidade diária/semanal de transbordo e transporte.

\subsection{Linguagem computacional}

O número de variáveis e dados envolvidos, bem como a relativa complexidade de suas inter-relações, foram as razões da confecção do modelo na forma computacional. O software selecionado para a tradução do algoritmo para a linguagem de programação 
foi o MS VISUAL BASIC ${ }^{\circledR}$, versão 6.0. SisColhe foi o nome escolhido ao programa de logística e simulação de colheita de cereais desenvolvido. O seu programa de instalação encontra-se disponível no Anexo A.

\subsection{SisColhe: verificação da rotina}

Qualquer modelo de simulação, seja ou não computacional, obrigatoriamente passa, durante o seu desenvolvimento, pela etapa denominada verificação da rotina. Por rotina é definido o conjunto de estruturas, funções, equações e seqüências de cálculos que o modelo executa, desde o inicio até o término de sua execução.

A rotina do SisColhe foi verificada em etapas, à medida que esse teve sua estrutura elaborada. A verificação, como o seu próprio nome sugere, foi realizada com o intuito de avaliar e eliminar a presença de erros na rotina. Por erro, classificou-se a montagem incorreta de equações, o seqüenciamento inadequado de estruturas e a não adequação de variáveis, dentre outros.

Fez-se, manualmente, todos os cálculos desempenhados pela rotina ao longo de sua estrutura, com o intuito de buscar não conformidades de resultados. Em conjunto, fez-se a análise de sua estabilidade frente a situações extremas como, por exemplo, a não entrada de inputs e a possibilidade de divisões por zero nas equações. Foram levados em consideração tanto os resultados parciais, pertencentes à estrutura interna do programa, quanto os finais, apresentados ao término das simulações.

\subsection{SisColhe: validação}

A validação é a etapa que analisa a consistência dos resultados oferecidos por um modelo, tornando-os validos ou não. Ela é realizada comparando-se os resultados que esse oferece, em pontos estratégicos de suas estruturas, com dados disponíveis por fontes bibliográficas e com dados característicos de situações reais.

O SisColhe foi validado em duas frentes: de custo e de desempenho. Quanto a primeira, os parâmetros selecionados foram o custo horário de colhedoras e de tratores e o custo quilométrico de veículos. Escolheu-se, de forma aleatória, dois exemplares de cada equipamento, pertencentes a marcas atualmente comercializadas no mercado, sendo 
a comparação dos resultados feita com valores sugeridos por Batavo (2003), FNP (2003) e Confederação Nacional de Transporte - CNT (2003).

Já quanto a validação do desempenho dos equipamentos, selecionou-se, como parâmetro, o tempo de duração de determinadas atividades de seus ciclos operacionais. Para as colhedoras, o tempo de enchimento do tanque graneleiro, de deslocamento aos veículos e de descarregamento da produção. Para as carretas graneleiras, os tempos de enchimento e esvaziamento dos compartimentos de armazenagem e, para os veículos, os tempos das viagens de ida e de volta à unidade de recepção. Como fonte de dados reais, considerou-se registros de desempenho de maquinaria disponibilizados por uma empresa agrícola localizada na região norte do Estado do Paraná, região essa reconhecida como tradicional produtora de cereais.

Os registros de desempenho foram feitos por avaliações realizadas no decorrer da colheita da safra 2002/03 de soja, nos 24 talhões da propriedade em questão. Para tanto, foram instalados, nas colhedoras, computadores de bordo que registravam, dentre outros, dados de seus tempos operacionais, ao longo de cada dia de colheita. Quatro máquinas, de uma frota de cinco, foram selecionadas para análise. Os computadores de bordo utilizados foram os da marca Auteq ${ }^{\circledR}$, sendo os modelos os pertencentes às séries 900 e 930. Os dados pertinentes ao desempenho das carretas graneleiras e dos veículos foram registrados pelos operadores, manualmente, em planilhas previamente preparadas. A caracterização técnica dos equipamentos validados, dos registros de desempenho e das planilhas elaboradas é apresentada no Anexo B.

\subsection{Cenários base}

As simulações características do estudo ocorreram a partir de três cenários iniciais, sendo, por essa razão, denominados de base. Suas elaborações tiveram por objetivo a análise do comportamento dos custos de sistema frente a variações de meta de produção, de posicionamento de veículos e de locação de talhões.

A mesma metodologia descrita por Oskan \& Edwards (1986) e utilizada por Milan (1992) foi aplicada. Os autores descrevem que, apesar de existirem similaridades entre fazendas que produzem as mesmas culturas, cada uma possui, normalmente, o seu 
próprio parque de máquinas. A fim de ilustrar a aplicação de seu modelo, os mesmos definiram fazendas hipotéticas, caracterizando-as quanto ao sistema de produção e à maquinaria. Diferentes cenários foram elaborados na avaliação das alterações em suas características.

A produção de cereais é qualificada por configurações distintas em termos de área, produtividade, distâncias, equipamentos e tecnologia. Não seria possível definir um sistema que agregasse a totalidade das características envolvidas. Em função disso, os três cenários base foram elaborados de modo hipotético, buscando apresentar como se comportam, como participam e como interagem os principais parâmetros. Os três têm suas mais relevantes características apresentadas na Tabela 2 e, o seu detalhamento, nos Anexos C e D.

Tabela 2. Principais características dos cenários base

\begin{tabular}{rrrr}
\hline Cenário Base & Área (ha) & $\begin{array}{r}\text { Posicionamento dos } \\
\text { veículos }(\mathrm{m})\end{array}$ & $\begin{array}{r}\text { Percurso de rota }(\mathrm{km})^{2} \\
\text { A }\end{array}$ \\
B & 700 & 130 & 2,2 \\
C & 2100 & 400 & 6,5 \\
& 10700 & 2000 & 32,2 \\
\hline
\end{tabular}

O cenário A é representativo de uma área relativamente pequena, localizada à uma pequena distância da unidade de recepção. Já o cenário B, de uma área padrão, à uma média distância e o C de uma grande área, localizada à uma maior distância. Todas as demais configurações, como os prazos de retirada, o sistema de colheita, a maquinaria e o padrão de operação foram mantidas constantes para os três.

A época de realização selecionada foi de 16 de março à 12 de abril, cumprindo um prazo de 4 semanas. Para os meses de março e abril considerou-se, respectivamente, 66 e 77\% dos dias como secos. Os índices foram fornecidos pela mesma empresa para a

\footnotetext{
${ }^{1}$ Valores aproximados.

${ }^{2}$ Distânciamento médio entre os talhões e a unidade de recepção, ao longo da safra, calculado pela média das distâncias dos talhões colhidos.
} 
qual os resultados de desempenho foram validados. Quanto à jornada diária, utilizou-se 10 h. A área a ser colhida foi composta por 16 talhões, todos abrigando a cultura da soja.

Em B, optou-se por utilizar talhões em suas características reais. Os 16 talhões simulados se referem àqueles a cultura da soja foi locada, para a safra 2003/2004, na empresa de validação de desempenho. Compuseram as suas caracterizações os dados de área, produtividade, produção, índice de eficiência e distância à unidade de recepção. A composição dos talhões em A e C foi feita tendo o cenário B como referência, ajustando a área, o posicionamento dos veículos e a locação dos talhões.

Quanto à maquinaria -colhedoras, tratores, carretas e veículos -, selecionou-se, no mercado, equipamentos de porte médio. Como o intuito, por ocasião da elaboração dos cenários, não foi avaliar o efeito de configurações de maquinaria distintas, e sim da área, do posicionamento dos veículos e da locação dos talhões, os mesmos equipamentos foram aplicados em todos os três cenários.

\subsection{Parâmetros de destaque: identificação e ordenação}

A análise de sensibilidade foi a ferramenta utilizada a fim de identificar os parâmetros de maior influência e/ou que possuem maior a participação na formação dos custos dos cenários base. Considerou-se duas categorias de parâmetros: parâmetros que afetam os custos, mas não são de gerência do tomador de decisão, denominados, assim, de externos e; parâmetros que afetam os custos e podem ser modificados por medidas gerenciais, assim denominados internos. Ambos tiveram seus valores de configuração nos cenários base alterados em uma mesma taxa, um de cada vez, por simulações individuais. Como a taxa foi mantida constante, pôde-se considerar que aqueles de maior alteração nos custos foram os que mais contribuíram para a sua formação, bem como os que mais exerceram influência em sua magnitude. A taxa utilizada foi de $30 \%$.

Optou-se pela taxa de 30\% em função da forma com a qual o programa efetua o cálculo do número de equipamentos requerido. Julgou-se adequado que apenas quando 30\% a mais de capacidade operacional fosse requerida, uma nova unidade fosse incluída à maquinaria. Em determinados parâmetros, alterações inferiores à esse valor não geram

diferenças significativas. É o caso do número diário de horas de operação. Caso esse 
fosse configurado inicialmente para 10 h, uma alteração de $10 \%$, o elevaria para $11 \mathrm{~h}$. Entretanto, caso o valor inicial fosse de 12 h, a mesma alteração o elevaria para 13,2 h, reduzindo substancialmente o número de equipamentos, efeito esse que não ocorre para o primeiro caso.

Após a identificação, a etapa seguinte foi a classificação dos parâmetros de maior significância, assim chamados críticos, por ordem de importância. Em seguida, procedeu-se a tabulação, sendo o agrupamento dos resultados feito por diagramas de Pareto.

\subsection{Custos: estrutura e alocação dos recursos}

Na colheita mecanizada, invariavelmente notam-se elevadas participações de recursos indiretos fixos ou de suporte na composição dos custos. Visando propiciar um melhor entendimento da formação desses, e de sua estrutura, utilizou-se, como método de custeio, o $A B C^{*}$. A seguir, as atividades, os recursos e os direcionadores, utilizados nas simulações, são apresentados.

\subsubsection{Definição das atividades}

As atividades desempenhadas pela maquinaria, às quais o seu custeio foi alocado, foram definidas como as etapas componentes de seu ciclo operacional. Esse, por sua vez, foi definido como o conjunto seqüencial de operações que cada componente do sistema, ou equipamento, realiza no cumprimento de sua função. As funções dos equipamentos no sistema de colheita são apresentadas a seguir.

Para as colhedoras, o ciclo de operações foi composto por quatro atividades básicas: colheita, deslocamento de ida, descarregamento e deslocamento de volta. A primeira corresponde ao tempo médio durante o qual as máquinas se encontram em plena retirada de produção, com a plataforma acionada e em velocidade normal de deslocamento. O descarregamento, como o seu próprio nome sugere, representa o tempo no qual as máquinas se encontram descarregando a produção, já colhida, que se encontra

* Quando o texto se referir ao Custeio Baseado em Atividades, a sigla ABC aparecerá em itálico, a fim de discernir da nomenclatura fornecida aos cenários base. 
armazenada em seu tanque graneleiro, nos transbordos ou nos veículos. Já a terceira e a quarta, os deslocamentos de ida e de volta, representam o tempo no qual as colhedoras permanecem em movimento, do ponto onde o corte estava sendo realizado até àquele no qual os veículos foram posicionados, e vice-versa, para que possam descarregar.

Algumas variações podem ocorrer no ciclo das colhedoras, devido ao modo de configuração das simulações. O descarregamento, por exemplo, pode ser feito tanto com as máquinas em movimento, com colheita simultânea de produção, quanto paradas. Os deslocamentos também podem ser dispensados, caso o sistema tenha sido configurado para a utilização de transbordos. Cada uma dessas possibilidades reflete-se, diretamente, na duração do ciclo dos equipamentos, fator determinante de custeio de suas atividades.

As atividades pertinentes aos transbordos e aos veículos, por sua semelhança, são apresentadas e detalhadas em conjunto. São quatro: carregamento, viagem de ida, descarregamento e viagem de volta. O carregamento é o tempo médio durante o qual as carretas e os veículos são carregados com a produção. No caso das carretas, a atividade é feita obrigatoriamente pelas colhedoras, podendo estar elas em movimento ou não. Já no dos veículos, essa pode ser efetuada tanto pelas colhedoras quanto pelos transbordos, dependendo do sistema selecionado. Contudo, independente do sistema, assumiu-se que os veículos permanecem parados durante toda a atividade. As viagens de ida e de volta são as atividades de movimentação, nas quais o transporte é efetivamente realizado e, o descarregamento, aquela na qual a produção é descarregada. Nos veículos, no caso dos transbordos, e na unidade de recepção, no dos veículos.

Da maneira como a rotina foi escrita, uma quinta atividade foi adicionada ao ciclo de todos os equipamentos: a eficiência. A eficiência com que as atividades são desempenhadas foi enfocada como um fator de acréscimo ao tempo teórico de duração dos ciclos. Por teórico, assumiu-se o tempo depreendido na totalização do ciclo para uma eficiência de 100\%. À medida que essa tem seu valor reduzido, os ciclos têm suas durações elevadas, na mesma proporção. Como representa essencialmente tempo, essa pôde também ser considerada uma atividade, tal como as demais, e teve, por essa razão, seu custeio alocado aos recursos de forma semelhante. 


\subsubsection{Explicitação dos recursos}

Na realização das atividades de colheita, diversos recursos são consumidos. Tanto por aquelas responsáveis pela retirada, quanto por aquelas pelo transbordo e pelo transporte da produção, dois recursos básicos foram considerados: equipamentos e mãode-obra direta. Embora seja sabido que, na prática, um maior número de recursos são necessários ao desempenho dessas atividades, tais como mão-de-obra indireta (auxiliares e ajudantes), pessoal de supervisão e instalações fixas (unidades de recepção), as suas participações não participaram do foco de análise desse estudo.

Uma vez que o recurso equipamentos envolve tanto custos fixos, quanto custos variáveis, um maior detalhamento se fez necessário. Ao invés de analisar o recurso como um todo, optou-se pela a sua decomposição entre os fatores de custo que o caracterizam. Assim, cada um dos componentes pôde ser analisado como um recurso em separado, o que possibilitou melhores visualizações e discernimentos do consumo de recursos pelas atividades. Seis fatores, no caso das colhedoras e das carretas graneleiras, e oito, no dos veículos de transporte, foram selecionados, com base no que propõem Hunt (1977) e Witney (1988), para o custeio da maquinaria agrícola, e CNT (2003), para os veículos de transporte.

A rotina de programação agrupa os componentes de custo em duas categorias: fixos e variáveis. A primeira engloba a depreciação, os juros sobre o capital investido e os encargos referentes às taxas, ao alojamento e os seguros. Já os componentes variáveis de custo envolvem o consumo de óleo combustível e lubrificante, os reparos, as peças, as manutenções e o custo de mão-de-obra direta. A metodologia de cálculo empregada é consagrada, e é apresentada por Hunt (1977), Witney (1988) e ASAE (1999a).

Para os equipamentos agrícolas, o componente depreciação foi calculado pelo

método linear. Assumiu-se que esses são utilizados durante toda a sua vida útil, na mesma empresa, o que torna desnecessário um maior detalhamento quanto à distribuição da taxa de amortização. A remuneração foi determinada sobre o capital médio investido, enquanto que, a vida útil, estimada por valores sugeridos por ASAE (1999b). Os custos referentes às taxas, ao alojamento e os seguros foram contabilizados como porcentagens incidentes sobre os valores de aquisição. Os valores utilizados são descritos no Anexo E. 
Todos os componentes variáveis são calculados segundo a base horária. O consumo de combustível é determinado pela potência requerida nos motores, sendo a equação de predição de consumo específico a proposta por Tachibana (1998). Os custos com reparos e manutenções são computados como porcentagens dos valores de aquisição distribuídas uniformemente ao longo de suas vidas úteis. Quanto aos operadores, a rotina assume os seus custos referentes apenas quando as máquinas estão em operação, e que, quando isso não ocorre, os mesmos se encontram realizando outras atividades, que não a colheita.

Para os veículos, a depreciação foi determinada de forma semelhante à maquinaria agrícola. A remuneração, contudo, se deu sobre o capital total, e não sobre o valor médio, em concordância com o que propõe CNT (2003). Os demais encargos fixos referiram-se às taxas de licenciamento e seguros, esses últimos facultativos. Os custos relativos aos motoristas foram assumidos como sendo do tipo de duração, como propõe o $A B C$, e não de intensidade. Todos os custos variáveis foram classificados como quilométricos. Os relativos ao combustível foram calculados pela razão entre o valor de mercado unitário, em R $\$ . \mathrm{L}^{-1}$ e o consumo, em $\mathrm{km} . \mathrm{L}^{-1}$, esse último informado durante o programa Transporte. A metodologia aplicada utilizada na determinação dos custos de pneus, de manutenção e de lubrificantes foi a sugerida por CNT (2003).

\subsubsection{Alocação dos recursos às atividades}

Para os equipamentos agrícolas, o tipo de direcionador que julgou-se refletir de forma mais adequada as relações de causa e efeito na execução das atividades foi do tipo de duração. Isso porque, invariavelmente, ocorrem variações apreciáveis no tempo de execução das atividades por eles desempenhadas, ou em função do sistema utilizado, ou em função nível de eficiência de sua realização. Nesse caso, para todos os componentes de custo, o direcionador selecionado, e utilizado, foi o tempo de operação da atividade.

Quanto aos veículos, selecionou-se o momento de transporte e a quantidade de carga transportada. O primeiro apresenta-se sob a forma composta. Ele é formado pelo produto entre a tonelagem transportada e a quilometragem percorrida. Assim, a parte do ciclo dos veículos desprendida efetivamente nas viagens teve o seu custo constituído por dois componentes: o custo quilométrico, diretamente proporcional à distância percorrida 
e o custo de duração, diretamente proporcional ao tempo desprendido. Uma vez que, nas simulações, a velocidade dos veículos foi considerada constante em todo o seu percurso, pôde-se efetuar a soma das duas parcelas de custo e dividir o resultado pelo momento de transporte, gerando, dessa forma, um custo unitário, em tonelada-km. Esse procedimento está em concordância com o que propõe Novaes (2001).

Para o direcionador quantidade de carga transportada, as atividades de carga e descarga, bem como os tempos de espera, não acarretaram nenhum custo quilométrico, pois os veículos permaneceram parados durante toda a sua execução. Desse modo, foi considerada apenas a parcela referente aos custos de duração, ou operacionais fixos.

\subsection{Desempenho de maquinaria: análises de comportamento e interações}

Nesse tópico, o objetivo foi buscar o entendimento de como se comportam e como se inter-relacionam os principais parâmetros determinantes de desempenho e custo da maquinaria. A metodologia utilizada como base para as análises constou da aplicação de análises de sensibilidade internas aos subsistemas, a fim de identificar os parâmetros de destaque. Em seguida, procedeu-se, por simulações sucessivas, o confrontamento e a tabulação dos resultados, visando plotar as curvas de comportamento das variáveis.

\subsection{Estratégias de colheita: elaboração}

As estratégias analisadas foram focadas no planejamento do prazo de retirada de produção, quanto às limitações de recebimento da unidade de recepção e de limitação de maquinaria, e no comportamento dos sistemas mediante a retirada dos componentes intermediários. Em ambas, fez-se análises do desempenho operacional e econômico dos sistemas. Os seus detalhamentos são descritos a seguir.

\subsubsection{Planejamento do prazo de retirada}

Uma das etapas mais decisivas do planejamento de colheita é a definição do prazo no qual a produção será retirada. Nessa fase, três fatores devem ser considerados: o risco de perda mediante a ação de fatores climáticos, a limitação imposta pela unidade de recepção e a limitação imposta pela capacidade operacional da frota. 
Os riscos de perda mediante a ação de fatores climáticos são proporcionais ao tempo de duração da operação. O mesmo ocorre com a perda econômica decorrente de reduções de produtividade e de qualidade dos grãos, causadas por retiradas tardias. Entretanto, os custos diretos da maquinaria elevam-se substancialmente com a redução do tempo disponível, o que pode inviabilizar a sua execução.

Em sistemas reais, os prazos de retirada podem ser limitados pelas unidades de recepção, caso essas não ofereçam condições suficientes de recebimento em um curto intervalo. Problemas como a adequação dos equipamentos de recepção, de secagem e de armazenagem estão envolvidos. Por outro lado, pode ser que o que limite o sistema não seja a capacidade de recebimento, mas sim a da frota. Nesses, mesmo que as unidades ofereçam condições, a capacidade da maquinaria pode limitar o prazo de retirada.

Dois cenários foram elaborados a fim de buscar estratégias que atendessem as necessidades de produção e de prazo estabelecidas pelo planejamento, mas oferecessem condições de redução dos custos de sistema. O primeiro deles, denominado cenário 1, é representativo da segunda limitação apresentada. Nele, o que impede a colheita de ser realizada em menos tempo é a capacidade de recebimento da unidade de recepção. O segundo, cenário 2, se refere àqueles sistemas nos quais o prazo de retirada é limitado pela capacidade da maquinaria. As suas principais características são apresentadas pela Tabela 3. Os talhões e a maquinaria simulados foram os empregados no cenário B.

Tabela 3. Resumo das principais características dos cenários de planejamento

\begin{tabular}{lcc}
\hline Características & Cenário 1 & Cenário 2 \\
\hline Fator limitante de prazo & Unidade de recepção & Maquinaria \\
Meta de produção (t) & 7476 & 7476 \\
Capac. de recebimento (t.dia ${ }^{-1}$ ) & 250 & 750 \\
Prazo de realização (semanas) & 6 & 2 \\
Datas & $16 / 03-26 / 04$ & $16 / 03-29 / 03$ \\
\hline
\end{tabular}

A mesma meta de produção, equivalente à do cenário $\mathrm{B}$, foi estabelecida para os dois cenários. Em função da limitação imposta pelas unidades, o prazo mínimo de 
colheita no primeiro cenário foi de 6 semanas. No cálculo, levou-se em consideração a porcentagem de dias secos para os meses de março e abril, de 66 e 77\%, e o número total de dias compreendido no período. A razão entre a meta de produção e o número de dias secos resultou na taxa média de recebimento do cenário, de 250 toneladas por dia. No segundo, a situação se inverte. Caso a frota possibilite, em 2 semanas existem condições de recebimento de toda a produção. Como, nesse, o prazo foi reduzido, a taxa de retirada diária precisou ser elevada para 750 toneladas a fim de permitir a retirada de toda a produção em 2 semanas. Preliminarmente à apresentação dos resultados, fez-se considerações sobre a capacidade de colheita da frota como função do nível de eficiência e da jornada diária. O objetivo foi propor uma forma simples de predição da capacidade diária de colheita, que servisse de auxilio ao planejamento do prazo de retirada.

\subsubsection{Retirada de transbordos}

O papel das carretas de transbordo, em sistemas de colheita, é o transporte da produção das colhedoras aos veículos de transporte. Elas representam, dessa forma, um elemento intermediário no sistema, e são utilizadas com o objetivo de evitar que as colhedoras se desloquem aos veículos a cada enchimento do tanque graneleiro, a fim de descarregar a produção. Contudo, a cada conjunto de transbordo exigido, o custo final da tonelada colhida é elevado, em reflexo ao maior consumo de recursos.

As avaliações desenvolvidas nesse tópico visaram analisar o comportamento dos sistemas mediante a retirada de seus componentes intermediários. As simulações foram realizadas em para os três cenários base e, em todos, o padrão de comportamento das variáveis de desempenho e de custo foi semelhante. O cenário B foi o escolhido para a apresentação dos resultados.

\subsection{Comparativo entre sistemas}

Nesse tópico, foi feito um comparativo entre os custos do sistema com transbordo e descarregamento em movimento, com transbordo e descarregamento sem movimento e do sistema sem transbordo. O parâmetro adotado como referência para explicitação dos custos foi o posicionamento dos veículos. 


\section{RESULTADOS E DISCUSSÃO}

\subsection{SisColhe: verificação da rotina}

A rotina do SisColhe foi verificada em etapas, à medida que esse teve as suas estruturas desenvolvidas. Em cada estágio, simulações parciais foram realizadas, com posterior confrontamento dos resultados por elas oferecidos com aqueles alcançados por cálculos manuais. De maneira conjunta, valores extremos foram inseridos como inputs, a fim de avaliar a estabilidade das estruturas. Ao final, nenhum cálculo errôneo quanto às determinações de desempenho ou quanto ao custeio das atividades foi mais encontrado.

\subsection{SisColhe: validação}

A validação é a etapa que analisa a consistência dos resultados oferecidos pelo modelo, tornando-os validos ou não. O SisColhe foi validado em duas frentes: de custo e de desempenho. Os resultados são apresentados a seguir.

\subsubsection{Validação quanto a custo}

A Figura 11 compara o custo horário de colhedoras oferecido pelo SisColhe e o valor sugerido por duas fontes bibliográficas. A utilização foi de 600 horas-ano.

Em ambas as máquinas, as maiores discrepâncias ocorreram com os dados de FNP (2003). Para a primeira, foi de $27 \%$ e, para a segunda, de $70 \%$. Na comparação com Batavo (2003), essas foram, respectivamente, de 5 e -2\%. A diferenciação nos valores é justificável, haja vista que, na bibliografia, são considerados os preços médios praticados no mercado, enquanto que, nas simulações, considerou-se o apenas o praticado na região norte do Estado do Paraná. Também, FNP (2003) não informa parâmetros importantes como as taxas de juros e os coeficientes de reparo e manutenção. 

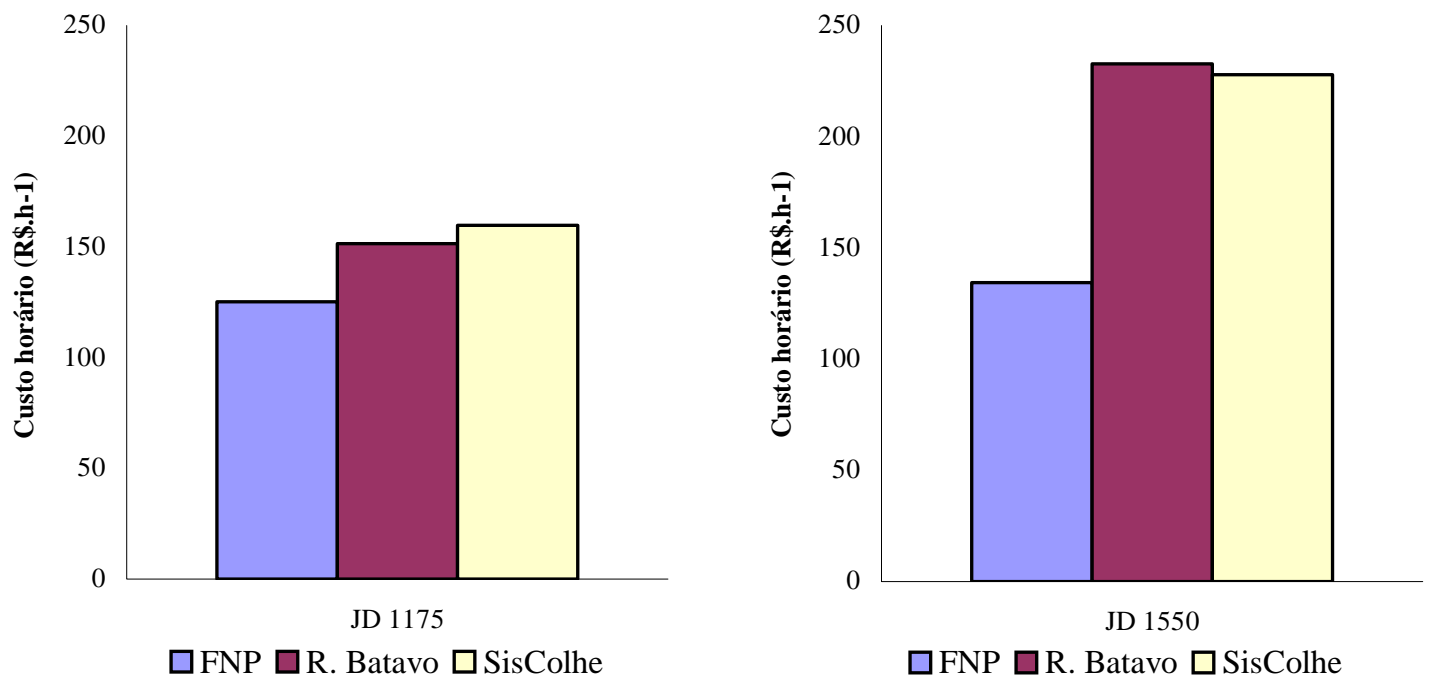

Figura 11 - Validação quanto ao custo horário de colhedoras

Os gráficos de validação quanto ao custo horário de tratores são apresentados pela Figura 12, para a utilização anual de 1000 h. As discrepâncias para o modelo MF 275/4 e MF 297/4, em relação a FNP (2003) e Batavo (2003) foram, respectivamente, de 50 e 42, e -4 e 9\%. Novamente, os valores sugeridos pelo primeiro autor demonstraram uma diferença acentuada em relação ao último e aos resultados do SisColhe.
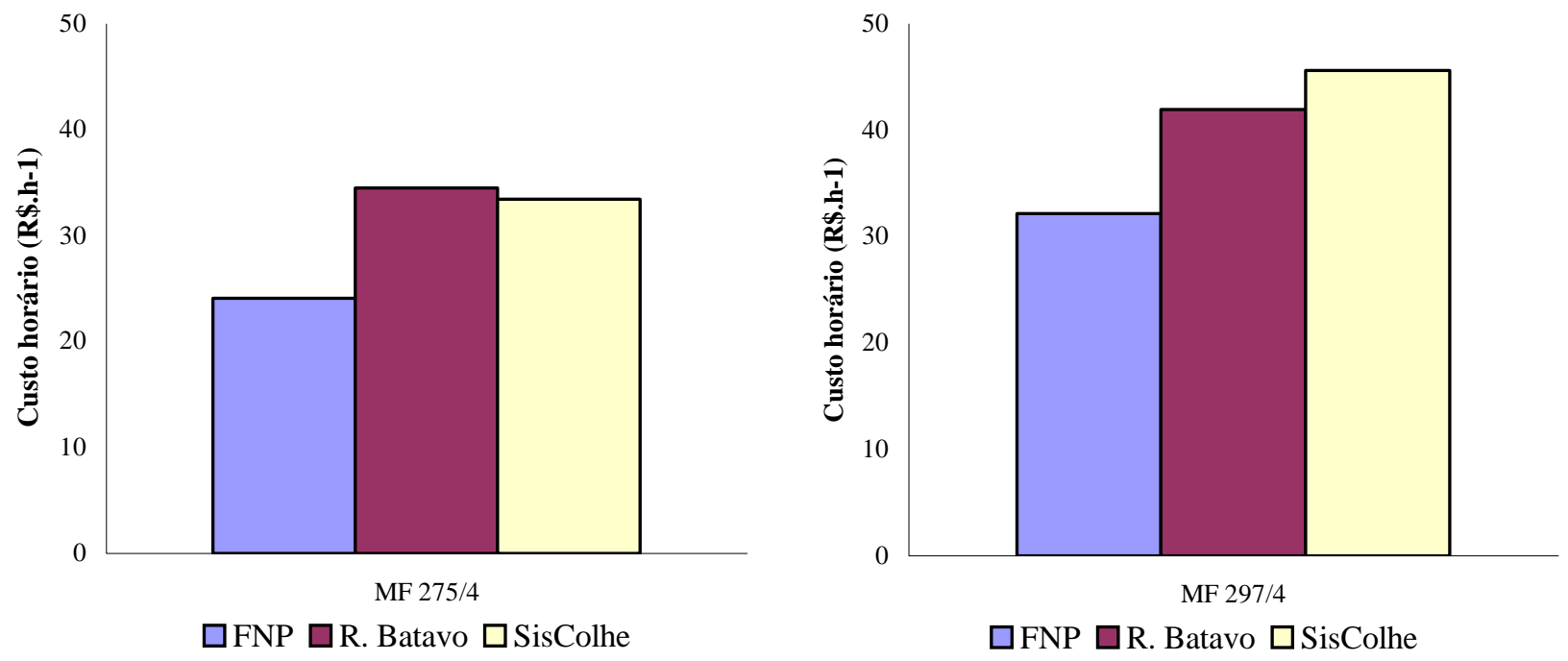

Figura 12 - Validação quanto ao custo horário de tratores 
Para o transporte, optou-se por validar apenas os custos quilométricos. Isso porque o custo fixo calculado pelo método ABC é tornado unitário na unidade de tempo, e não na de distância, como o calculo pela bibliografia tradicional, o que impossibilita as suas comparações. As comparações, feitas para um caminhão e uma carreta, em relação a CNT (2003), apresentaram discrepância inferior a 20\% (Figura 13).
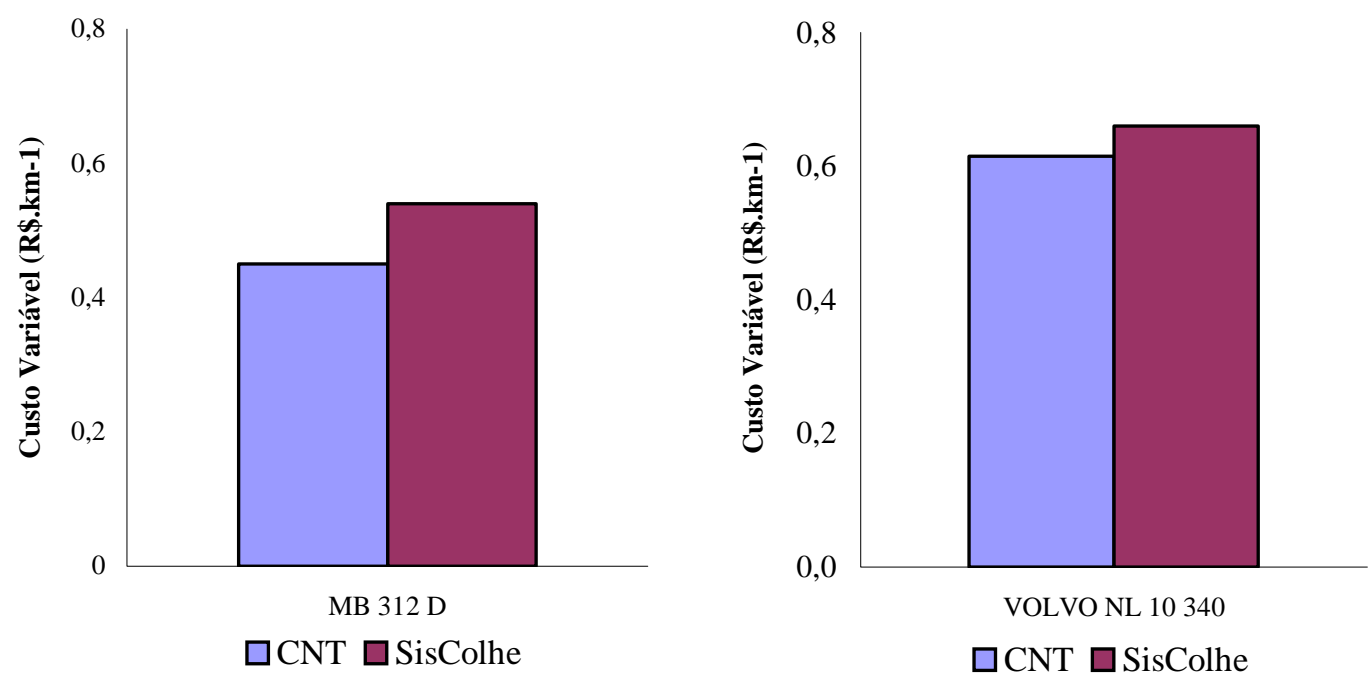

Figura 13 - Validação quanto ao custo quilométrico de veículos

\subsubsection{Validação quanto a desempenho}

Quanto ao desempenho, os resultados do SisColhe foram tornado validados por registros reais de operação da maquinaria, levantados na safra 2002/03 (Figuras 14, 15 e 16).

Para as colhedoras, três atividades foram selecionadas: colheita, deslocamento e descarregamento. A colheita representa o tempo médio que as colhedoras desprendem no enchimento de seus graneleiros, e foi dela a maior discrepância. O SisColhe diferiu em 1,8 minutos, o equivalente a 8\%, do tempo dos registros. Entretanto, vale destacar que diversos fatores influenciam o tempo de enchimento dos graneleiros e, além disso, todos demonstram variações no tempo e/ou no espaço. Destacam-se a produtividade da cultura, o aproveitamento da largura nominal da plataforma, a velocidade de colheita e o peso especifico dos grãos. Em situações reais, a produção por unidade de área é uma 
característica variável, mesmo em curtas distâncias. Nas simulações, uma produtividade única foi considerada para cada talhão, e esse é um dos fatores que justifica a diferença obtida. Em relação aos demais fatores, todos os três são assumidos como constantes, embora também variem. As diferenças para o deslocamento e para o descarregamento foram de 5 e $13 \%$.

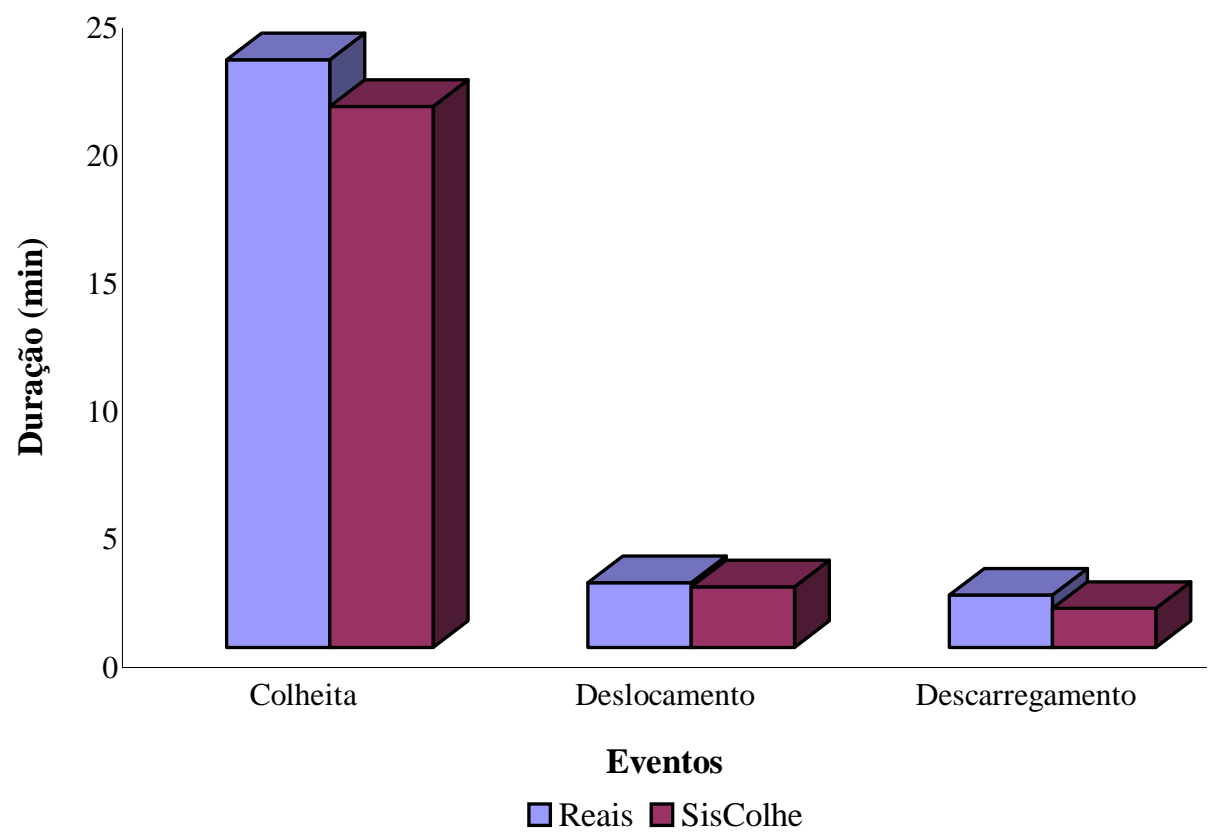

Figura 14 - Validação quanto a duração das atividades de ciclo - colhedoras

Aos operadores dos transbordos foi solicitado o registro manual do tempo de duração dos eventos de seus ciclos. A diferença entre os valores calculados e os registrados pelos operadores foi da ordem de segundos, e não ultrapassou 10\%. De fato, o tempo de enchimento do compartimento de armazenagem das carretas graneleiras é função exclusiva de suas capacidades úteis de carga e da vazão do tubo de descarga das colhedoras, ambos parâmetros essencialmente numéricos e de pouca variação temporal, o que torna as determinações mais precisas. 


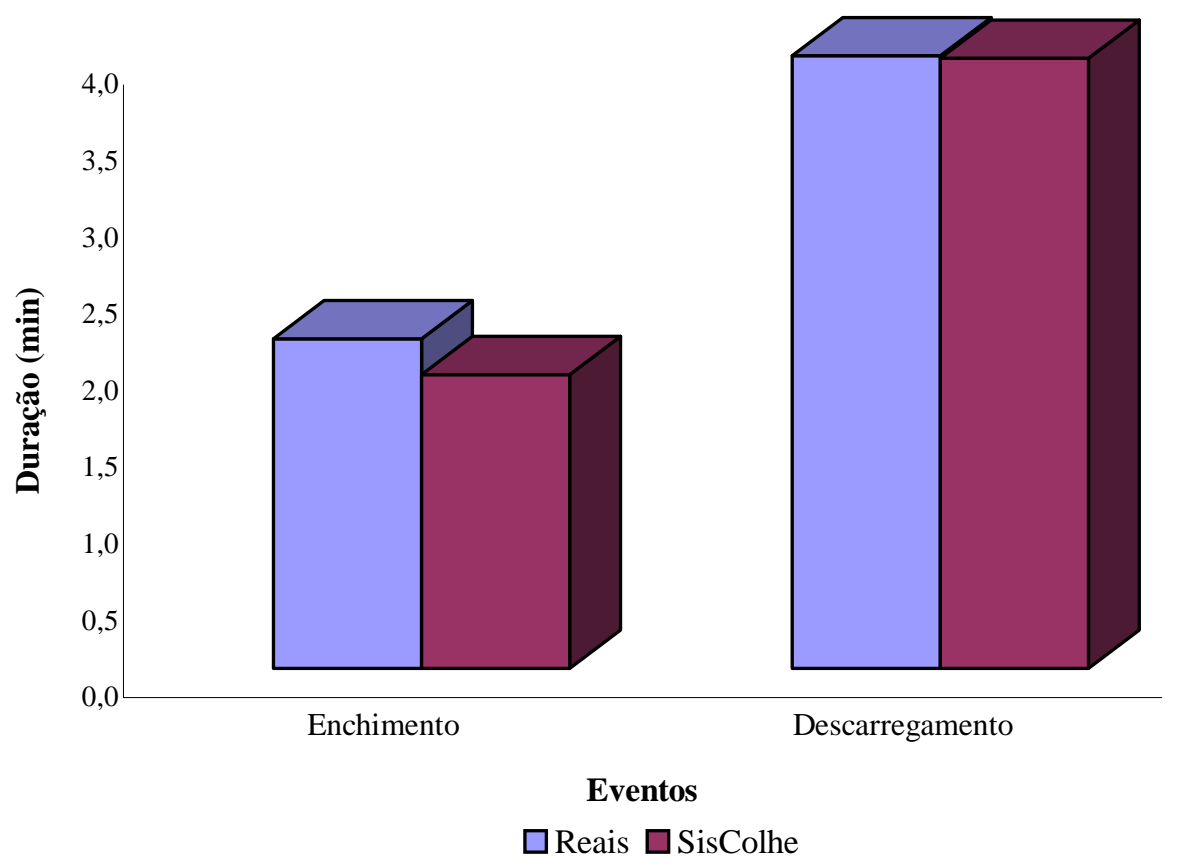

Figura 15 - Validação quanto a duração das atividades de ciclo - carretas graneleiras

A validação quanto ao desempenho dos veículos foi feita quanto as suas velocidades nas viagens de ida e volta aos talhões. No SisColhe, cabe ao usuário indicar quais as velocidades características da simulação. Entretanto, esses são valores únicos, e são mantidos constantes ao longo de toda a colheita. Essa é uma simplificação imposta ao algoritmo. Em situações reais, as velocidades oscilam entre e, principalmente, durante as viagens. A Figura 16 mostra as velocidades máxima e mínima registradas pelos operadores. Os registros constam dos deslocamentos em um dia especifico de colheita da safra. Na validação, foi inserido o valor de $50 \mathrm{~km} . \mathrm{h}^{-1}$ para a viagem de ida. Contudo, houve viagens nas quais a velocidade de ida média foi de $70 \mathrm{~km} . \mathrm{h}^{-1} \mathrm{e}$, outras, de 38. De forma semelhante, embora todas as viagens de volta tenham sido simuladas a 35, houve aquelas nas quais foram registrados valores médios de 48 e $25 \mathrm{~km} . \mathrm{h}^{-1}$. 


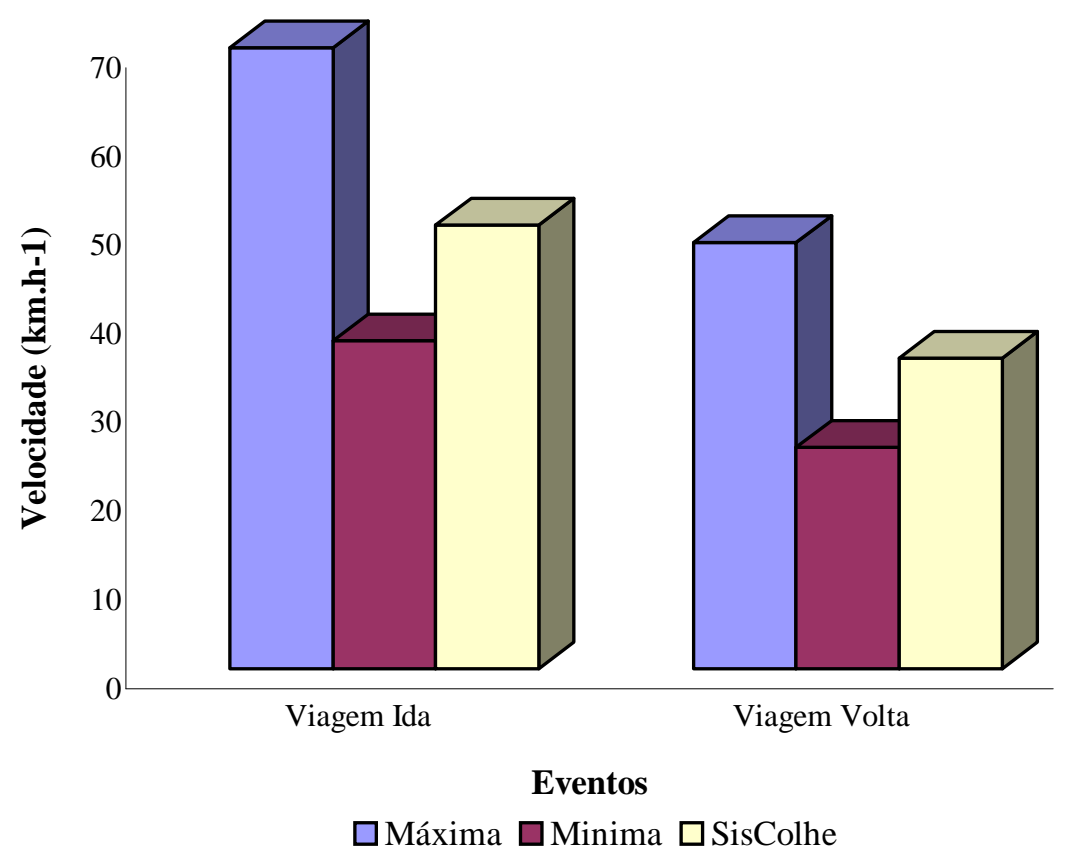

Figura 16 - Validação quanto a duração das atividades de ciclo - veículos

É verdade que houve discrepâncias dos resultados oferecidos pelas simulações com os valores sugeridos por fontes bibliográficas, ou mesmo com os registros reais de desempenho. Em contrapartida, trata-se de um modelo de simulação, no qual diversas simplificações se encontram implícitas. Em situações reais, a maquinaria e mesmo as culturas estão sujeitas as mais diversas fontes de variação. Uma vez que a lógica de comportamento da maquinaria pôde ser reproduzida, julgou-se as diferenças alcançadas aceitáveis ao propósito do estudo.

\subsection{Cenários base}

A Tabela 4 mostra um resumo contendo os custos dos subsistemas, os custos totais e as produções envolvidos em cada um dos cenários base elaborados.

O somatório dos custos de colheita, de transbordo e de transporte foi maior no cenário C do que nos demais, como esperado. À medida que a colheita de maiores áreas e, por conseqüência, de maiores produções, foi agendada, o desprendimento de capital elevou-se substancialmente. Enquanto a produção em $C$ foi cinco vezes superior à do 
cenário B, seu custo final é praticamente sete. De fato, quanto maior foi a retirada de produção, maior foi o número de horas-máquina necessário à totalização das atividades. O mesmo ocorreu para o consumo de recursos variáveis. Dentre os principais, os combustíveis, os lubrificantes e os custos de manutenção. Uma análise detalhada da estrutura de custos e do consumo de recursos é feita no item 4.5. As relações entre os custos e as receitas a serem obtidas com a comercialização ${ }^{1}$ da produção oscilaram entre 5 e $7 \%$.

Tabela 4. Custos e produções envolvidos com os cenários base A, B e C

\begin{tabular}{lccc}
\hline \multicolumn{1}{c}{ Subsistemas } & \multicolumn{3}{c}{ Cenários } \\
& A & B & C \\
\hline Colheita & 48,4 & Custos $\left(\mathrm{R} \$ \times 10^{3}\right)$ & 546,4 \\
Transbordo & 23,5 & 109,3 & 552,9 \\
Transporte & 10,0 & 78,5 & 365,0 \\
Total & 82,0 & 34,3 & 1464,2 \\
& & 222,0 & 37,5 \\
Total & 02,5 & Produção (t x 10 $\left.{ }^{3}\right)$ & \\
& & 07,5 & 0,07 \\
Total & 0,06 & Relação Custo/Receita & \\
\hline
\end{tabular}

A distribuição dos custos entre os subsistemas é mostrada pela Figura 17. A distribuição se mostrou função da área a ser colhida e da locação dos talhões frente à unidade de recepção. A colheita foi sempre uma parte significante dos custos. Em A, o subsistema colheita foi responsável por 60\% de todos os custos envolvidos com a retirada e transporte da produção. Todavia, sua significância foi reduzida à medida que as rotas a serem percorridas pelos veículos, nas viagens de ida e volta aos talhões, e pelos transbordos, nas de ida e volta aos veículos, foram mais distantes. A importância

\footnotetext{
${ }^{1}$ Valor de mercado considerado: US\$12,00/saca 60 kg e taxa de câmbio R \$2,80/US\$1,00.
} 
do transporte, de $12 \%$ em A, se elevou para $25 \%$ em C. Nesse, a distribuição foi mais eqüitativa, com os custos de transbordo inclusive superando os de colheita.

\section{Cenários}

A

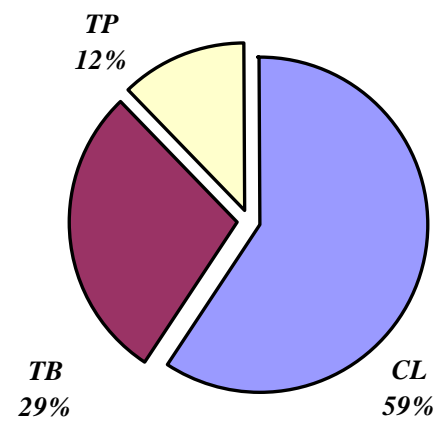

B

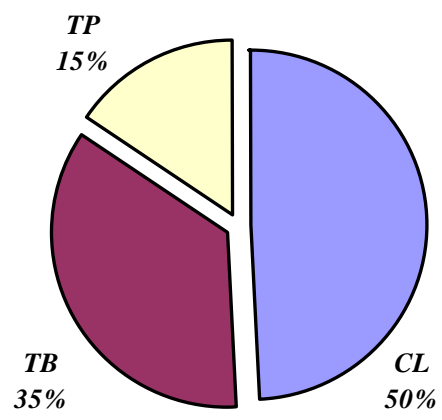

$\mathrm{C}$

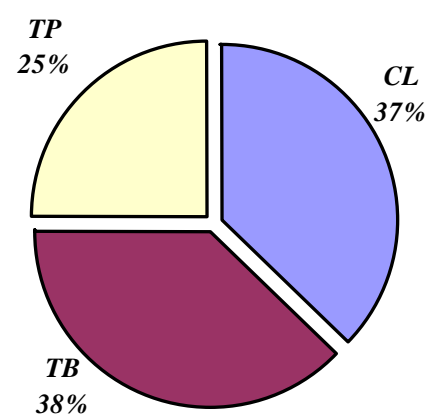

Figura 17 - Distribuição percentual dos custos totais dos cenários base entre os seus subsistemas: Colheita (CL), Transbordo (TB) e Transporte (TP)

Da maneira como a rotina foi escrita, caso o sistema seja configurado para operar com transbordos, toda a produção obrigatoriamente passa por esses antes de chegar aos veículos. Elevadas produções, transbordadas a longas distâncias, exigem um grande número de tratores e carretas graneleiras, equipamentos esses muitas vezes de elevado valor. Em reflexo ao maior dimensionamento da frota em B e C, o custo do subsistema se incrementou. Principio similar traduz o comportamento dos custos de transporte. A proporção relativa ao transbordo e transporte juntos, que em A foi de $41 \%$, em $\mathrm{C}$ foi $63 \%$, próxima a dois terços do valor total.

\subsection{Parâmetros de destaque: identificação e ordenação}

\subsubsection{Fatores externos}

Os efeitos nos custos dos cenários, em função de alterações nos parâmetros que os elevam, são apresentados pela Figura 18. O método adotado constou do acréscimo individual de cada parâmetro em 30\%, com posterior ordenação dos resultados. 
Segundo a classificação por categoria, os componentes fixos mostraram-se mais determinantes na formação de custo do que os variáveis. Especificamente, embora a sua participação tenha ocorrido a diferentes taxas, o fator de maior contribuição ao aporte de capital foi o valor de comercialização das colhedoras no mercado.

Essa discrepância é justificável. Em comparação com o restante da maquinaria, as colhedoras foram, de longe, os equipamentos de maior valor. Enquanto os tratores e os veículos foram cotados no mercado por, respectivamente, R\$ 144.000 e R\$ 95.000, só a colhedora foi a R \$ 345.000. Somando-se a essa a cotação da plataforma, de R \$ 49.000, teve-se um valor total, por unidade, de R\$394.000. Mediante tal diferença, é esperado que esse tenham sido os equipamentos cujo valor mais contribuiu à formação do custo.

Em semelhança com o demonstrado pelos cenários base, a participação dos custos de colheita, e por conseqüência de seus componentes, no custo final, se mostrou função de dois fatores: (i) área a ser colhida e; (ii) locação dos talhões. Também os custos se mostraram sensíveis a esse comportamento, haja vista que a significância do valor das colhedoras foi reduzida à medida que as rotas de transbordo e transporte foram elevadas. Em A, sua contribuição foi o dobro da do segundo fator; já em C, apenas 14\%. De um modo geral, e como será discutido, a aquisição de máquinas de elevado valor somente se justifica caso essa traga consigo incrementos compensatórios de capacidade efetiva.

O retorno financeiro sobre o capital médio investido foi outro fator importante. Equipamentos de grande valor inevitavelmente geram elevados custos de oportunidade, uma vez que a possibilidade de melhor retorno em fundos de investimento é superior. Para que os sistemas se caracterizem por menores custos de oportunidade, o valor de aquisição e/ou a taxa de juros sobre a qual o capital é custeado devem ser reduzidos. Programas de financiamento que têm, como forma de incentivo, crédito a longo prazo e sob baixa taxa de juros,são alternativas interessantes. 


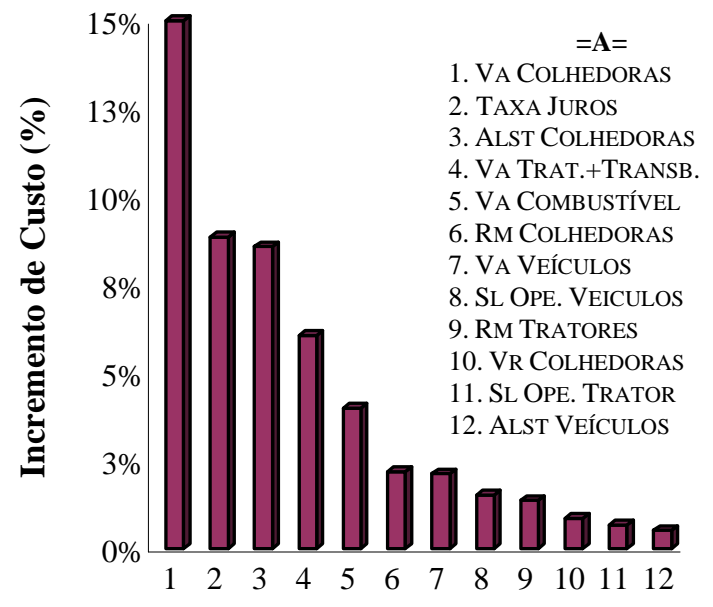

Parâmetros

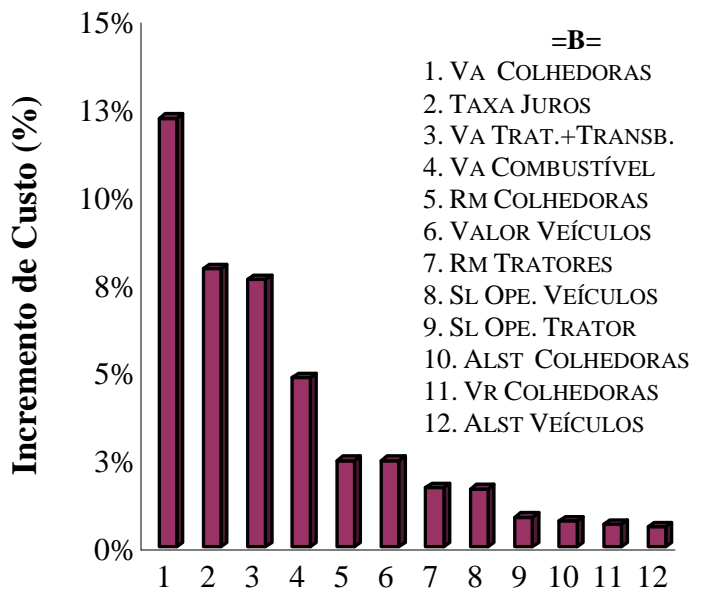

Parâmetros

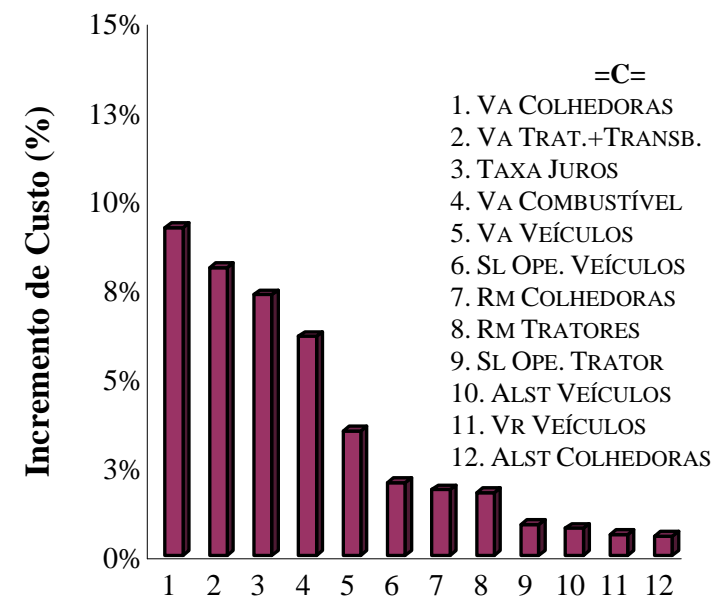

Parâmetros

Figura 18 - Os efeitos nos custos dos cenários em função de alterações em seus parâmetros externos

Dentre os recursos variáveis, o combustível figurou na primeira posição. Embora tenha contribuído significativamente em todos os cenários, sua participação se elevou de A para C, como reflexo do maior número de horas-máquina consumido nas atividades. Sua redução passa certamente pela aquisição de maiores lotes e pela elaboração de estratégias que maximizem a eficiência de operação. Enquanto a primeira proporciona melhores condições de negociação, a segunda enfoca a redução de tempos que, apesar de improdutivos, geram consumo, elevando o valor de custeio da tonelada. 
O segundo recurso variável foi o custo de reparo e manutenção, de forma especial as taxas relativas às colhedoras e aos tratores. Da forma com a qual a rotina foi escrita, cada equipamento tem seu custo de manutenção estimado como uma porcentagem do seu valor de aquisição distribuída ao longo de sua vida útil. Como ocorre na realidade, máquinas de maior valor geram encargos horários maiores. O mesmo ocorre com aquelas de menor vida útil. Como as colhedoras, dentre os demais, são os equipamentos que mais agregam ambas as características, é natural que elas tenham se destacado também no consumo desse recurso. Nos equipamentos de transporte, o comportamento é exatamente o inverso. A vida útil de caminhões e carretas pode chegar, em alguns modelos, a um milhão de quilômetros, diluindo os encargos horários a eles aplicados.

Quanto aos custos de mão-de-obra, aqueles de maior contribuição foram relativos aos salários pagos aos motoristas. Aqui, cabem duas justificativas. Primeiro, os salários desses, na maioria das situações, são superiores aos dos operadores de maquinaria. E, segundo, também os custos de duração envolvidos com o transporte são maiores.

Em se tratando de valor de revenda, nenhum equipamento mostrou ser esse um parâmetro de grande contribuição. As colhedoras, devido ao seu maior valor, foram as de maior significância. Entretanto, de uma forma geral, quanto menor for o valor de revenda da maquinaria ao final de sua vida útil, maior o valor a ser depreciado e o custo de investimento do capital.

Os resultados demonstraram que, em distintas configurações, a importância relativa dos parâmetros se altera. Esse comportamento sugere que, em sistemas reais, a tomada adequada de decisão requer a análise desses em suas próprias características. A Figura 19 apresenta os cinco parâmetros externos de maior influencia na formação de custo, e demonstra essa premissa. Em B e C, o valor dos tratores, das carretas graneleiras e dos veículos, bem como o custo de combustível, elevam suas participações. 


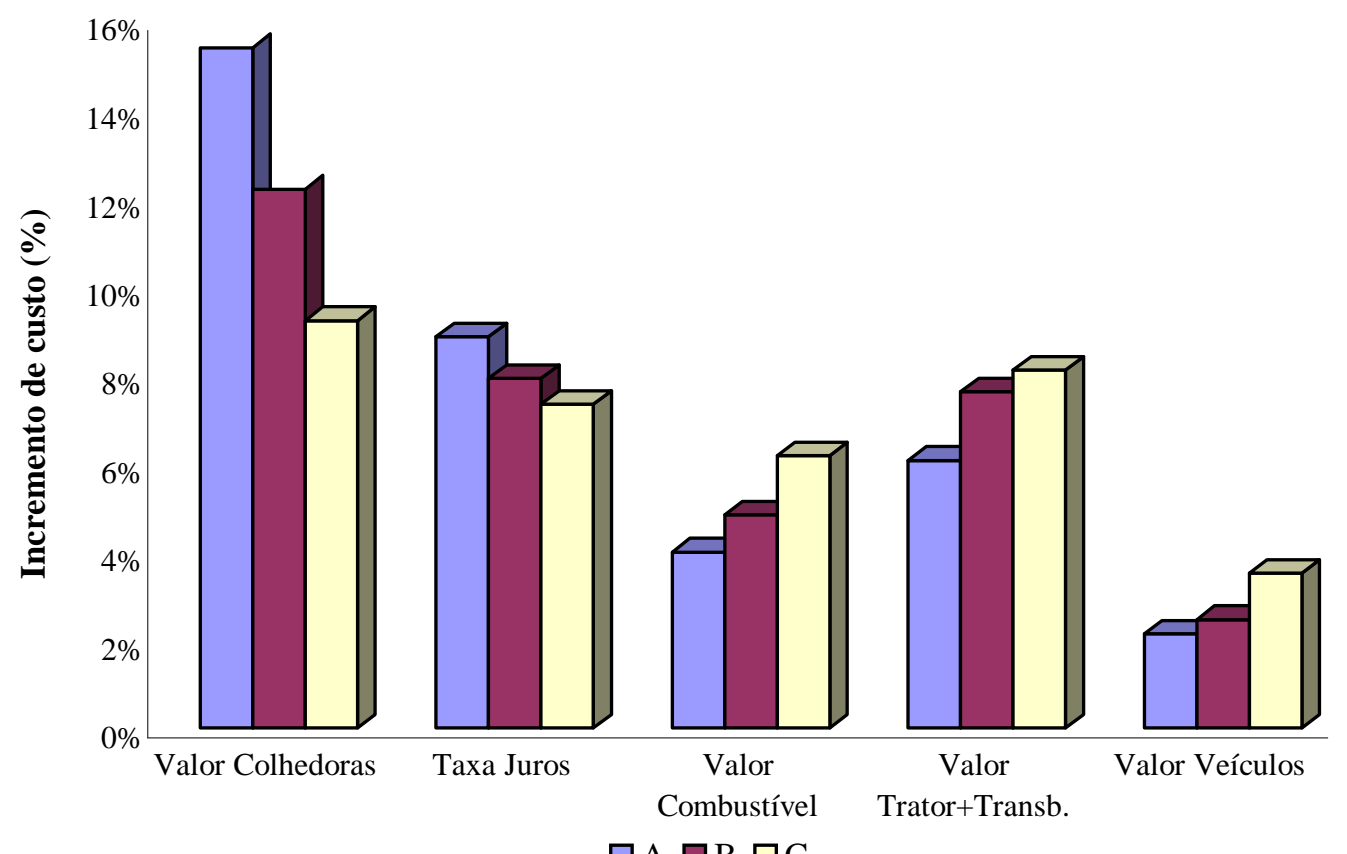

Figura 19 - Incrementos de custo dos cinco parâmetros externos de maior destaque

\subsubsection{Fatores internos}

A mesma metodologia descrita no item anterior foi utilizada. Uma taxa constante de 30\% foi aplicada ao valor inicial dos parâmetros. Contudo, dessa vez, as alterações visaram proporcionar incrementos de desempenho e reduções de custo aos cenários. Os efeitos nos custos em função de alterações nos parâmetros são apresentados na Figura 20.

A capacidade potencial da frota de colhedoras demonstrou ser o parâmetro no qual residem as maiores possibilidades de redução de custo. O segundo foi a sua eficiência de operação. Ambas são, matematicamente, as variáveis que determinam a capacidade real das colhedoras de retirar a produção, em quantidade por unidade de tempo. De fato, a capacidade de retirada da frota demonstrou reger, inclusive, o desempenho de carretas graneleiras e veículos.

Em A, vê-se, de forma nítida, que os parâmetros nos quais as atenções devem ser concentradas são, em primeiro lugar, a capacidade potencial, ou efetiva, das 
colhedoras e, em segundo, as utilizações anuais e as eficiências de operação dos equipamentos. A vida útil das colhedoras e dos tratores também se mostrou importante.

Em contrapartida, à medida que as áreas e as rotas foram incrementadas, os parâmetros relacionados ao transbordo e ao transporte da produção tiveram seus potenciais de redução de custo incrementados (Figura 21). Em B e C, a participação na formação de custo, de parâmetros como a capacidade de carga de veículos e carretas graneleiras, bem como as distâncias a serem por eles percorridas, foi maior.

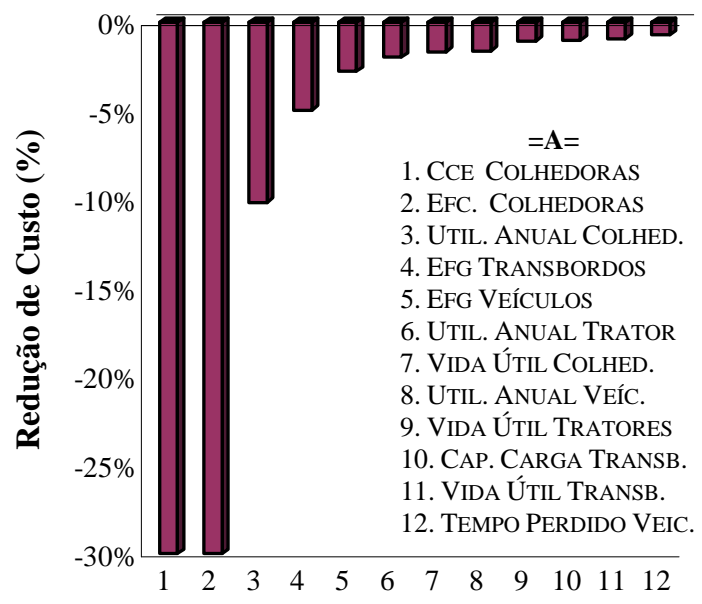

Parâmetros

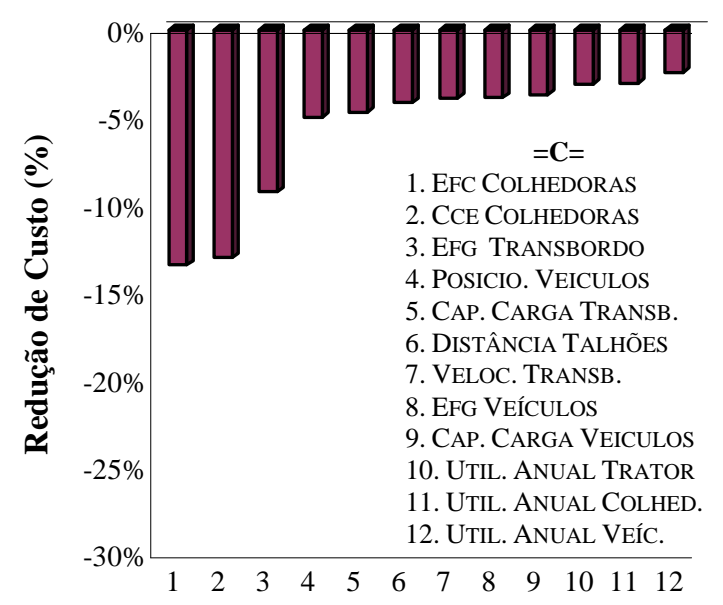

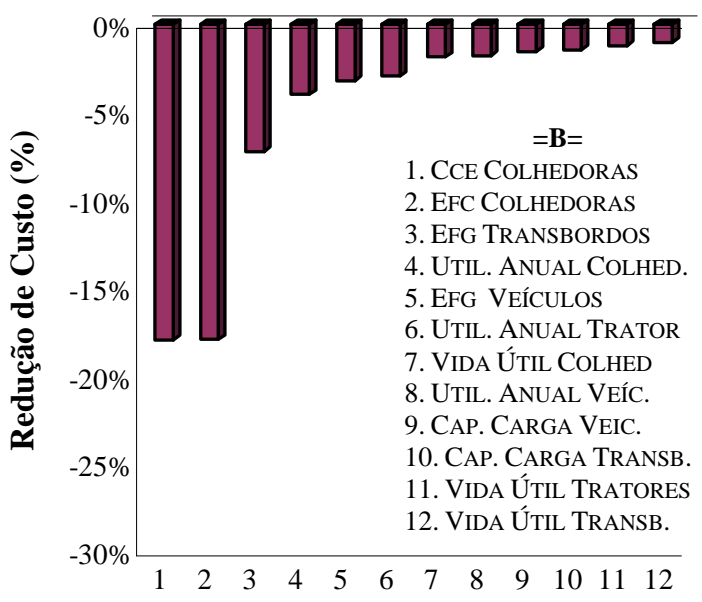

Parâmetros

Parâmetros

Figura 20 - Os efeitos nos custos dos cenários em função de alterações em seus parâmetros internos 


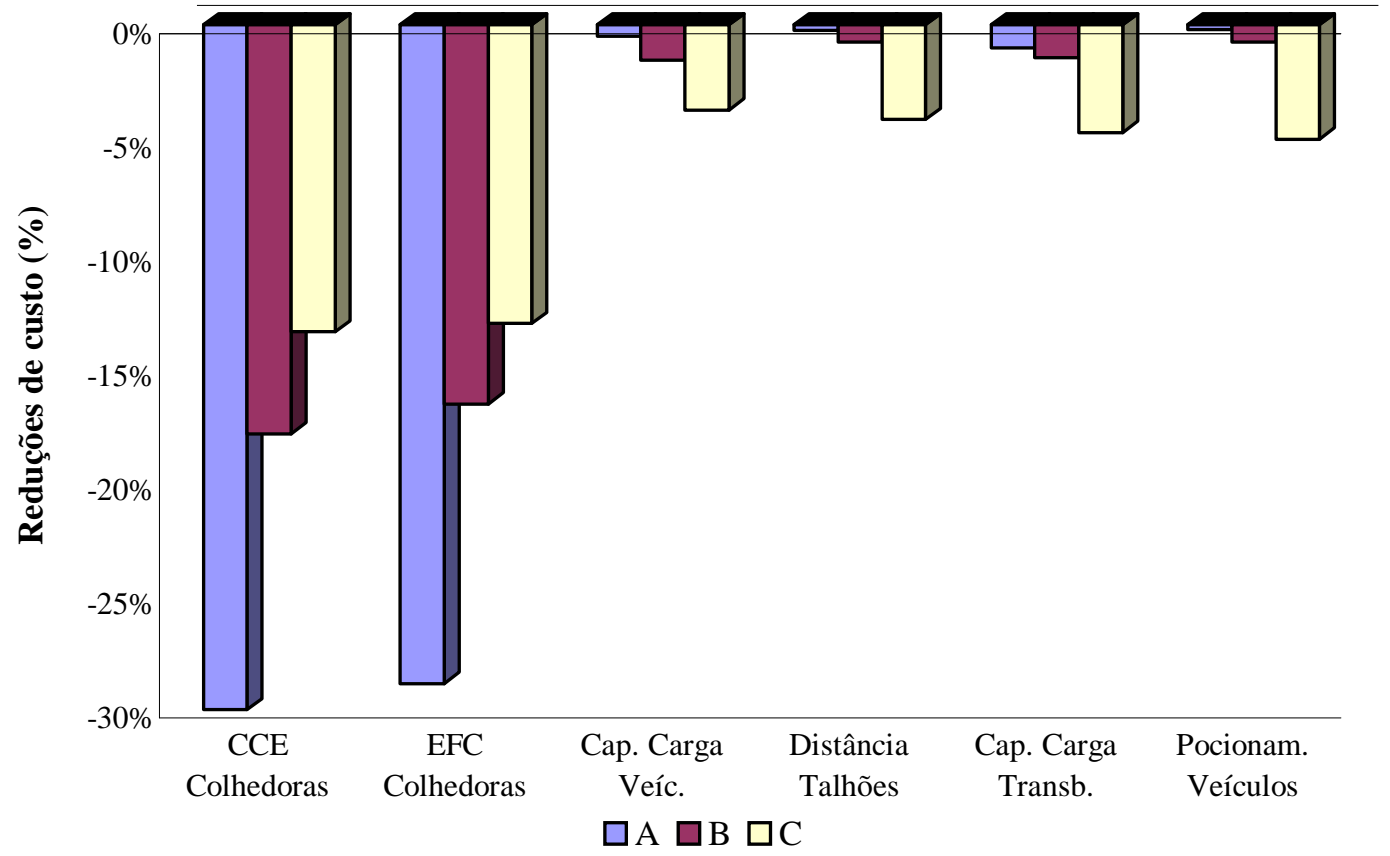

Figura 21 - Reduções de custo dos cinco parâmetros internos de maior destaque

\subsection{Custos: estrutura e alocação dos recursos}

A aplicação do método de custeio $A B C$ nas operações que compõem a colheita mecanizada teve, por objetivo, garantir uma melhor alocação dos recursos consumidos às atividades desempenhadas pela maquinaria, da retirada ao transporte da produção. A seguir, a formação e a estrutura dos custos dos três subsistemas são apresentados.

\subsubsection{Colheita}

A Tabela 5 mostra o custeio do subsistema colheita por meio do agrupamento de seus custos unitários por recurso utilizado, para os três cenários base.

Duas importantes características destacam-se na Tabela 7. Primeiro, é fator notório a elevada participação dos recursos fixos na composição dos custos finais de colheita. Em nenhum dos três cenários analisados, a depreciação, o custo de oportunidade e as taxas de alojamento e seguro, representaram, juntas, menos de dois terços do custo de retirada da produção. 
Tabela 5. Custos de colheita da safra agrupados por recurso

\begin{tabular}{lrrrrr}
\hline Cenário & $\begin{array}{r}\text { Recurso } \\
\text { utilizado }\end{array}$ & Tipo de Custo & $\begin{array}{r}\text { Custo por } \\
\text { safra }\left(R \$ . t^{-1}\right)\end{array}$ & $\begin{array}{r}\text { Participação } \\
(\%)\end{array}$ & $\begin{array}{r}\text { Total } \\
\left(R \$ . t^{-1}\right)\end{array}$ \\
\hline A & CF & Custo Fixo & 14,44 & 74,3 & 19,43 \\
& CV & Custo Variável & 4,99 & 25,7 & \\
B & CF & Custo Fixo & 9,63 & 65,9 & 14,62 \\
& CV & Custo Variável & 4,99 & 34,1 & \\
C & CF & Custo Fixo & 9,63 & 65,9 & 14,62 \\
& CV & Custo Variável & 4,99 & 34,1 & \\
\hline
\end{tabular}

Em A, representativo de pequenas propriedades, essa diferenciação no consumo dos recursos foi ainda mais acentuada. Nesse, $75 \%$ dos custos de colheita foram de responsabilidade de componentes fixos. Como reflexo dessa maior contribuição, os custos de colheita nesse cenário se mostraram substancialmente superiores aos demais. A curva apresentada pela Figura 22 propicia melhor compreensão desse comportamento. Ela foi obtida por simulações sucessivas, alterando em um módulo de 100 ha a área a ser colhida no cenário B e mantendo constantes todas as demais configurações.

Os custos de colheita se mostraram superiores para áreas menores. Isso devido à menor utilização das colhedoras ao longo do ano, o que acarreta maiores encargos de custo fixo por hora trabalhada. À medida que a colheita de maiores áreas é agendada, os custos são reduzidos, mediante a distribuição dos encargos fixos em um maior número de horas.

Contudo, nota-se um padrão de redução em “zig-zag”, e não continuo, com o acréscimo das áreas. Nesse, os custos vão se reduzindo progressivamente até o ponto no qual apenas uma colhedora não é mais suficiente para que toda a produção possa ser retirada no prazo estipulado, requerendo a aquisição de uma nova máquina. Como o número de colhedoras se eleva, ambas têm suas utilizações reduzidas ao longo do ano, o que eleva os encargos fixos horários e, por conseqüência, os custo de retirada da 
tonelada. Com novos acréscimos de área, esses são novamente reduzidos até o ponto a partir do qual uma colhedora adicional é requerida.

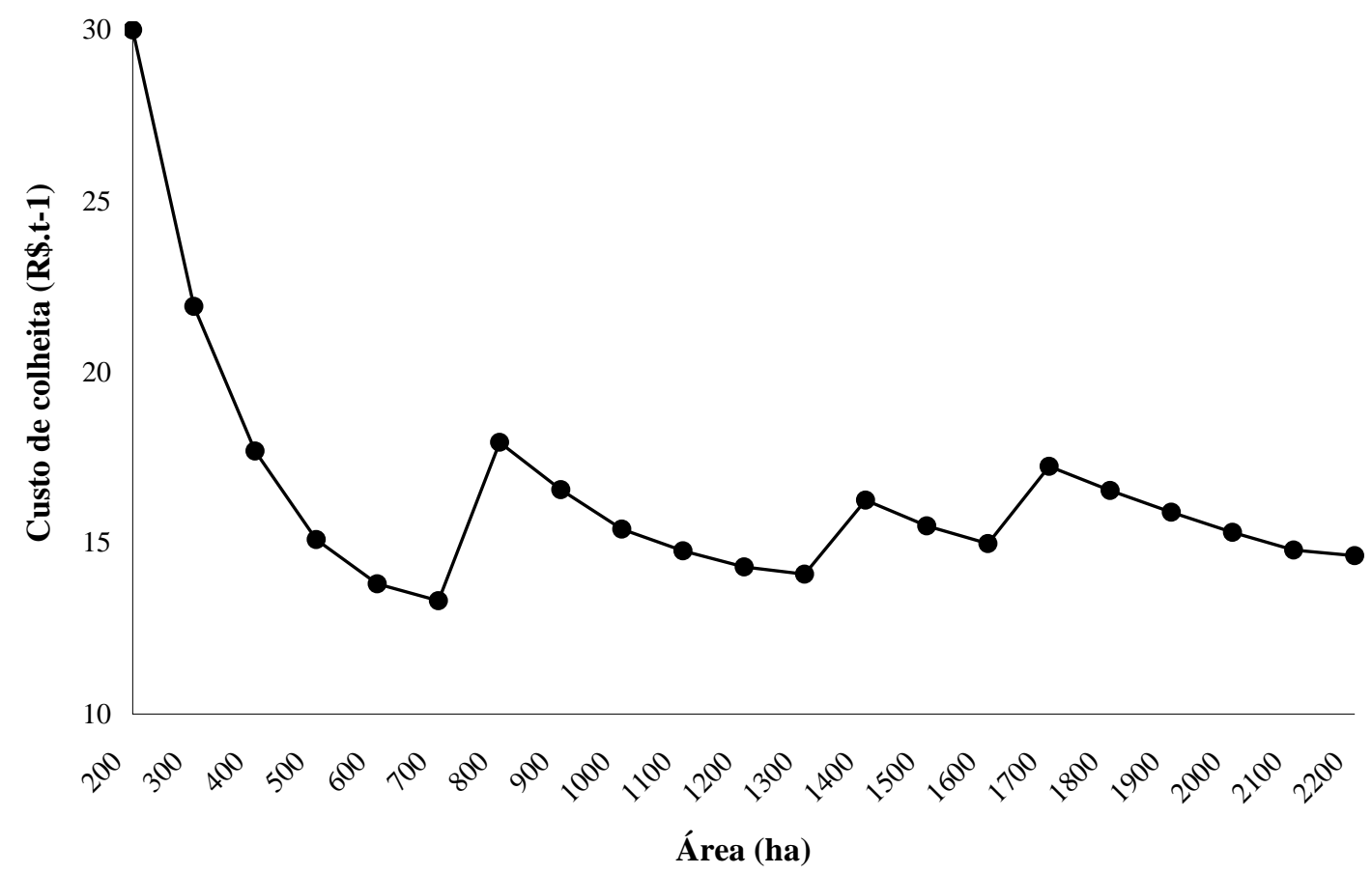

Figura 22 - Comportamento do custo unitário de colheita frente à acréscimos na área a ser colhida

Os pontos de acréscimo de custo, nas simulações, foram os referentes às áreas de 800, 1400 e 1700 ha. Para maiores áreas, nota-se uma redução da amplitude dos picos de acréscimo de custo, como reflexo da utilização anual das colhedoras. Em 800 ha, toda a utilização de uma única máquina foi divida pela metade. Já em 1400 ha, o número de horas de duas passou a ser dividido por três e, em 1700 ha, de três por quatro. Como as diferenças se reduziram , o mesmo ocorreu com o acréscimo de custo referente à adição de novas máquinas.

De fato, de todos os parâmetros considerados, dois em especial influenciaram os encargos fixos que incidiram sobre a maquinaria agrícola. Como fator externo, o valor inicial de aquisição dos equipamentos e, como interno, o número de horas que compõe a sua utilização anual. Certamente, se o intuito for reduzir o valor a ser 
amortizado e o custo sobre o capital investido, os pontos de enfoque devem ser: (i) optar pela aquisição de equipamentos que exijam menores desprendimentos de capital e; (ii) elevar, ao máximo, o número de horas que os mesmos operam no ano. Isso porque muitos dos componentes de custo da maquinaria, tanto os diretos quanto os indiretos, estão relacionados ao seu valor de aquisição. Destacam-se, dentre eles, a depreciação, a taxa de juros e as taxas de reparo e manutenção. Assim, maiores desprendimentos de capital só se justificam se os ganhos em capacidade se mostrarem compensatórios.

Segundo, é também destacável a permanência dos custos variáveis específicos da operação em um mesmo patamar, independentemente do cenário analisado. Todos eles apresentaram consumo de recursos variáveis de ordem de R 5 por tonelada colhida. A fim de buscar o seu entendimento, foram simuladas as curvas de comportamento dos custos fixos e variáveis frente aos custos operacionais anuais e aos específicos da maquinaria. As simulações foram realizadas para o cenário B, e são mostradas pela Figura 23.
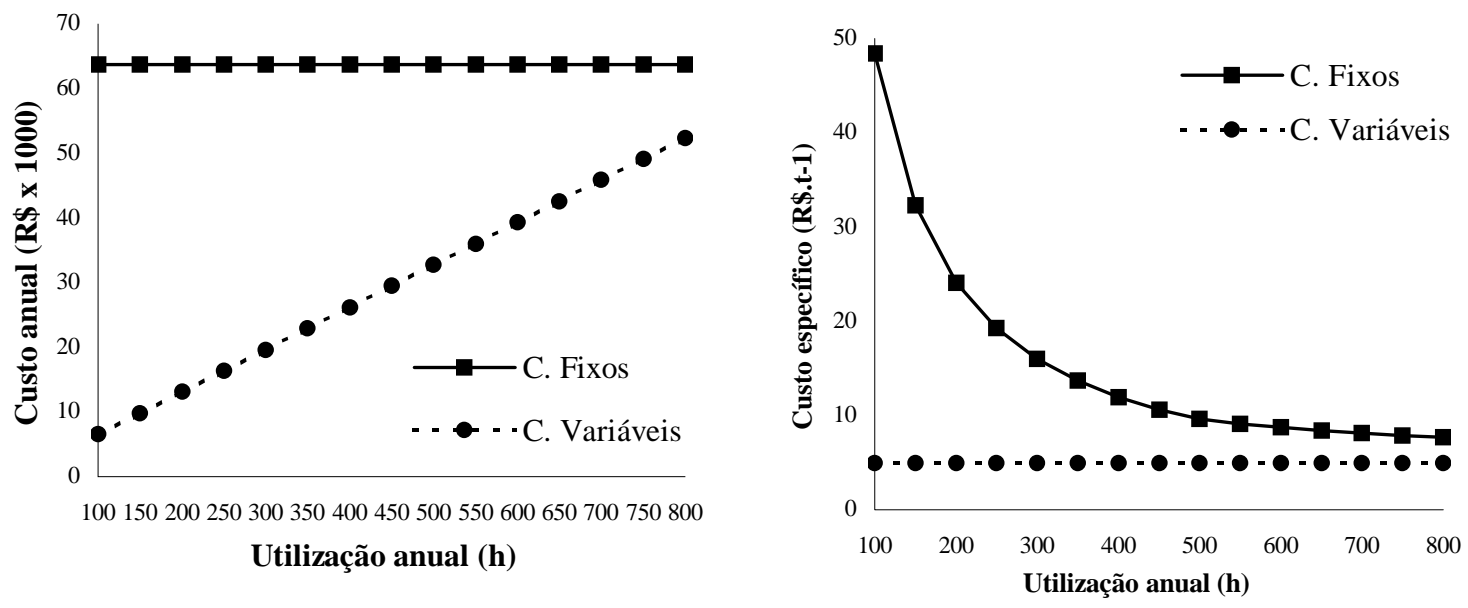

Figura 23 - O efeito contrastante dos custos fixos e variáveis frente à: (a) custos operacionais anuais e (b) custos operacionais específicos

Na formação dos custos anuais, em termos totais, os custos fixos se mostraram constantes por ano, com os custos variáveis sendo elevados direta e proporcionalmente à utilização anual das máquinas (Figura 23a). Por outro lado, com o enfoque nos custos 
específicos de colheita, em $\mathrm{R} \$ . \mathrm{t}^{-1}$, foram os custos variáveis os que se mantiveram constantes, com os custos fixos sendo reduzidos pela distribuição dos encargos em um maior número de horas ao longo do ano (Figura 23b). De fato, na formação dos custos específicos de colheita, os componentes fixos dos encargos se tornaram variáveis e, os variáveis, fixos.

A Tabela 6 apresenta a alocação dos custos das atividades desempenhadas pelas colhedoras ao longo de seus ciclos aos recursos utilizados. As simulações foram feitas para o cenário B.

Tabela 6. Desagregação dos custos de colheita por recurso e por atividade (R\$.t $\left.{ }^{-1}\right)$

\begin{tabular}{lrrrrr}
\hline $\begin{array}{l}\text { Atividade } \rightarrow \\
\downarrow \text { Recurso }\end{array}$ & Colheita & $\begin{array}{r}\text { Desloca } \\
\text { mentos }\end{array}$ & $\begin{array}{r}\text { Descarrega } \\
\text { mento }\end{array}$ & Eficiência & Total \\
\hline Depreciação & 3,11 & - & - & 1,39 & 4,50 \\
Juros & 3,05 & - & - & 1,36 & 4,41 \\
ALST & 0,50 & - & - & 0,22 & 0,72 \\
RM & 1,66 & - & - & 0,74 & 2,40 \\
Combustível & 1,49 & - & - & 0,67 & 2,15 \\
Operador & 0,30 & - & - & 0,13 & 0,43 \\
Total & 10,10 & - & - & 4,52 & 14,62 \\
\hline
\end{tabular}

As duas únicas atividades que consumiram os recursos destinados à retirada da produção foram a colheita e a eficiência. Tal comportamento já era esperado, haja vista o sistema de colheita selecionado. Nos cenários base, o sistema de colheita selecionado se caracteriza pela utilização de transbordos e pelo descarregamento da produção em movimento. Assim, tanto os tempos de deslocamento quanto os de descarregamento das colhedoras são dispensados, uma vez que essas não necessitam se deslocar aos veículos e nem interromper a colheita para descarregar.

Como mostra a Tabela 6, os fatores de maior potencial para redução de custo são justamente os que influenciam diretamente as atividades nas quais os recursos foram consumidos. Maiores capacidades efetivas reduzem o tempo de duração da atividade de 
colheita, o que reduz o custo da operação. O mesmo raciocínio é válido a eficiência. Quanto maior for o nível de eficiência, uma menor quantidade de tempos improdutivos é acrescida aos ciclos, e os custos são reduzidos.

É importante ressaltar que, dentre os sistemas de colheita existentes, o utilizado na elaboração dos cenários é o que propicia o melhor aproveitamento do potencial de retirada da produção das máquinas. À medida que à essas são atribuídas atividades acessórias, tais como se deslocar, ou mesmo descarregar sem movimento, esse potencial é reduzido. Como as referidas atividades, mesmo que acessórias, consomem recursos, o custo de retirada da produção é elevado. A Tabela 7 apresenta a alocação dos custos das atividades das colhedoras, para o mesmo cenário anterior, agora com a atividade de descarregamento incluída no ciclo operacional das colhedoras.

Tabela 7. Desagregação dos custos das colhedoras por recurso e por atividade (R\$. $\left.\mathrm{t}^{-1}\right)$, sistema com transbordo intermediário, descarregamento sem movimento

\begin{tabular}{lrrrrr}
\hline $\begin{array}{l}\text { Atividade } \rightarrow \\
\downarrow \text { Recurso }\end{array}$ & Colheita & $\begin{array}{r}\text { Desloca } \\
\text { mento }\end{array}$ & $\begin{array}{r}\text { Descarrega } \\
\text { mento }\end{array}$ & Eficiência & Total \\
\hline Depreciação & 3,49 & - & 0,39 & 1,74 & 5,63 \\
Juros & 3,42 & - & 0,39 & 1,70 & 5,51 \\
ALST & 0,56 & - & 0,06 & 0,28 & 0,90 \\
RM & 1,66 & - & 0,19 & 0,83 & 2,67 \\
Combustível & 1,49 & - & 0,17 & 0,74 & 2,40 \\
Operador & 0,30 & - & 0,03 & 0,15 & 0,48 \\
Total & 10,92 & - & 1,23 & 5,44 & 17,59 \\
\hline
\end{tabular}

Os recursos são alocados às atividades desempenhadas pelas colhedoras com base em seu tempo de duração. O descarregamento da produção, que para o modelo de colhedora utilizado nas simulações é feito em aproximadamente 1,6 minuto, teve seu custo estimado em um valor superior à R\$ 1,20 por tonelada colhida. O custo total, por sua vez, sofreu um acréscimo de $20 \%$, apenas com o acréscimo dos tempos de 
descarregamento. As diferenças entre o potencial de retirada da produção das colhedoras nesses dois sistemas são apresentadas pela Tabela 8, para o cenário B.

Tabela 8. Comparativo entre diversos parâmetros de desempenho e de custo das colhedoras frente às duas formas de descarregamento

\begin{tabular}{rrr}
\hline Parâmetros de desempenho e custo & \multicolumn{2}{c}{ Forma de Descarregamento } \\
& Em movimento & Sem movimento \\
\hline Produção Colhida (t) & 7476 & 7476 \\
Tempo de Ciclo (min) & 13,6 & 15,2 \\
Capacidade Operacional (t.h $\left.{ }^{-1}\right)$ & 13,2 & 11,8 \\
Descarregamentos & 603 & 542 \\
Horas-Máquina (h) & 568 & 632 \\
Deslocamento de viagem (km) & 0,0 & 5,0 \\
Número & 4 & 17,59 \\
Custo de colheita (R\$.t ${ }^{-1}$ ) & 14,62 & 34,01 \\
\hline
\end{tabular}

Para que a mesma produção fosse retirada no prazo estipulado, apenas a inclusão do descarregamento no ciclo operacional das colhedoras fez com que esse tivesse seu tempo elevado de 13,6 para 15,2 minutos. O aumento de duração dos seus ciclos, por sua vez, fez com que as máquinas tivessem reduzidas as suas capacidades de retirar a produção em 11\%, de 13,2 para 11,8 toneladas para cada hora de operação. Como conseqüência, o número de ciclos, ou descarregamentos, que cada uma foi capaz de realizar ao longo da safra foi também reduzido. Como a meta de produção a ser retirada foi mantida, e as colhedoras passaram a perfazer um menor número de descarregamentos, o número de horas-máquina necessário à totalização da operação foi elevado, e a aquisição de uma nova colhedora foi programada. Como mostram os resultados, essa perda de potencial foi refletida diretamente nos custos de colheita. Uma vez que os demais componentes do sistema têm seus desempenhos vinculados ao desempenho das colhedoras, os custos de sistema também se elevam. O ordenamento 
dos recursos consumidos por ordem de contribuição, de acordo com a Tabela 9, é apresentado na Figura 24.

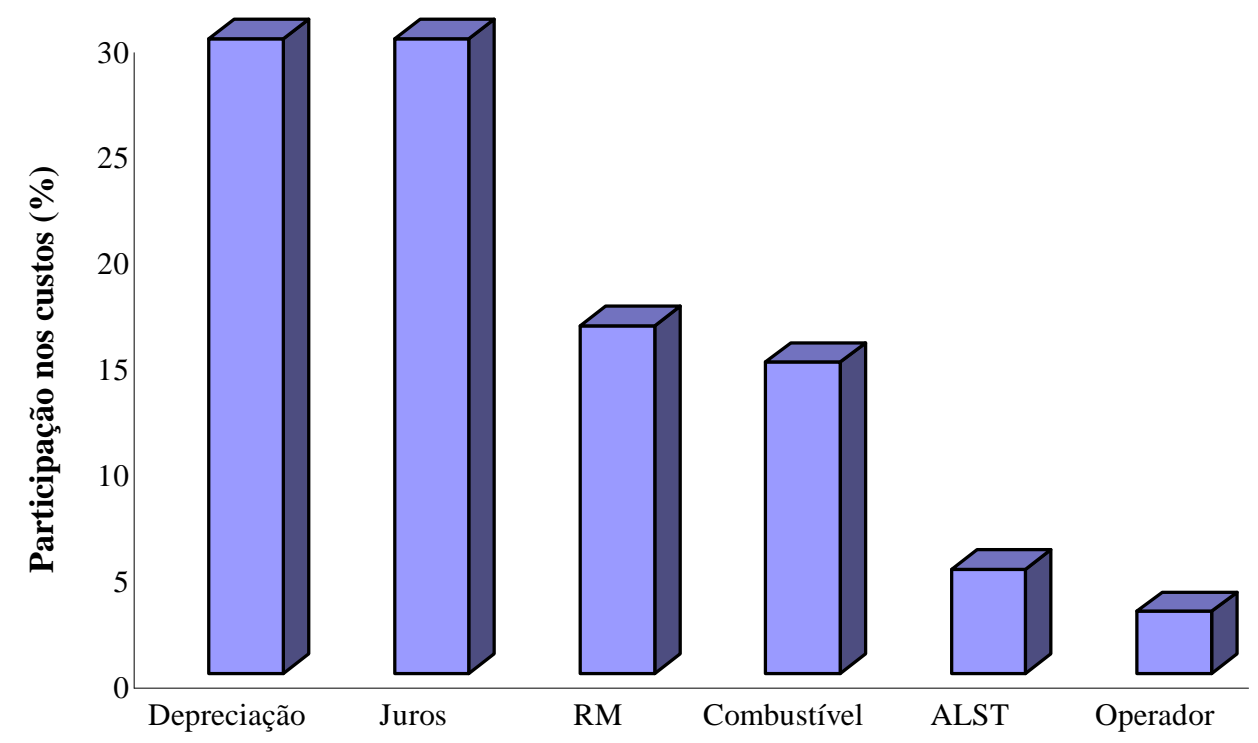

Recursos

Figura 24 - Ordenação dos recursos utilizados na retirada da produção por participação percentual

A depreciação, em concordância com o que relata Hunt (1977), foi o componente de maior participação nos custos das colhedoras. Juntas, ela e a taxa de juros, ambas componentes fixos, representaram mais de $61 \%$ dos recursos consumidos na retirada da produção. Na seqüência vieram os custos de reparo e manutenção e de combustível e, no último patamar, os de alojamento, taxas e seguro e os custos de mãode-obra.

Os parâmetros que devem ser enfocados visando a redução dos encargos fixos são o valor com que as máquinas são adquiridas e o número de horas no qual essas são utilizadas ao longo do ano. Sob esse enfoque, a melhor solução passa, inevitavelmente, por análises de custo benefício entre valores de aquisição e capacidades efetivas. De forma ideal, o compromisso entre valor de aquisição e capacidade de trabalho deve ser 
sempre a referência a ser seguida pelo tomador de decisão no momento de compor e de planejar a sua frota.

Os valores de aquisição influenciam também, dois dos custos variáveis. De forma direta, as taxas de reparo e manutenção, haja vista que máquinas maiores requerem um maior desprendimento de capital com a manutenção e reposição de suas peças componentes, maiores em número e em complexidade, ao longo de sua vida útil. Os custos com combustível, por sua vez, também se elevam, mediante a maior potência dos motores e a maior demanda dessa para o acionamento dos sistemas internos das máquinas e conseqüentemente para a realização da operação.

\subsubsection{Transbordo}

A Tabela 9 apresenta a alocação dos custos das atividades desempenhadas pelos transbordos ao longo de seus ciclos aos recursos utilizados. As simulações foram feitas para cenário B.

Tabela 9. Desagregação dos custos de transbordo por recurso e por atividade (R\$. $\left.\mathrm{t}^{-1}\right)$, cenário B

\begin{tabular}{lccccc}
\hline $\begin{array}{l}\text { Atividade } \rightarrow \\
\downarrow \text { Recurso }\end{array}$ & Carreg. & Viagens & Descarreg. & Eficiência & Total \\
\hline Depreciação & 1,50 & 0,25 & 0,63 & 0,42 & 2,80 \\
Juros & 1,20 & 0,20 & 0,50 & 0,33 & 2,23 \\
ALST & 0,20 & 0,03 & 0,08 & 0,05 & 0,36 \\
RM & 1,13 & 0,19 & 0,47 & 0,32 & 2,10 \\
Combustível & 1,18 & 0,19 & 0,49 & 0,33 & 2,20 \\
Operador & 0,43 & 0,07 & 0,18 & 0,12 & 0,81 \\
Total & 5,64 & 0,93 & 2,35 & 1,58 & 10,50 \\
\hline
\end{tabular}

No cenário B, no qual os veículos se encontram posicionados a distância média de $400 \mathrm{~m}$, os transbordos desprenderam a maior parte dos seus ciclos nas atividades de carga/descarga. Como os direcionadores utilizados na alocação dos recursos foram do 
tipo de duração, o carregamento e o descarregamento, atividades de maior tempo de execução, demonstraram ser as de maior contribuição para o consumo de recursos.

O tempo de carregamento de uma carreta graneleira é função de suas capacidade úteis de carga e da capacidade das colhedoras de retirar a produção. Quanto maior for a taxa de retirada de produção das colhedoras, menos tempo o transbordo permanece em espera, desencadeando melhorias em seus desempenhos.

Os tempos de descarregamento, por sua vez, dependem de características gerenciais, dentre elas os tempos auxiliares e os perdidos (tempos de espera, de manobra e de acionamento do tubo de descarga) e de características de projeto dos transbordos, dentre eles a sua capacidade de carga e vazão de descarga. Novamente, quanto mais rápido for o descarregamento, melhor o desempenho dos transbordos, e menor o custo do subsistema. À medida que aumentou o distanciamento entre colhedoras e veículos, mais tempo foi desprendido em viagem, o que alterou a distribuição das atividades na alocação dos recursos (Figura 25).

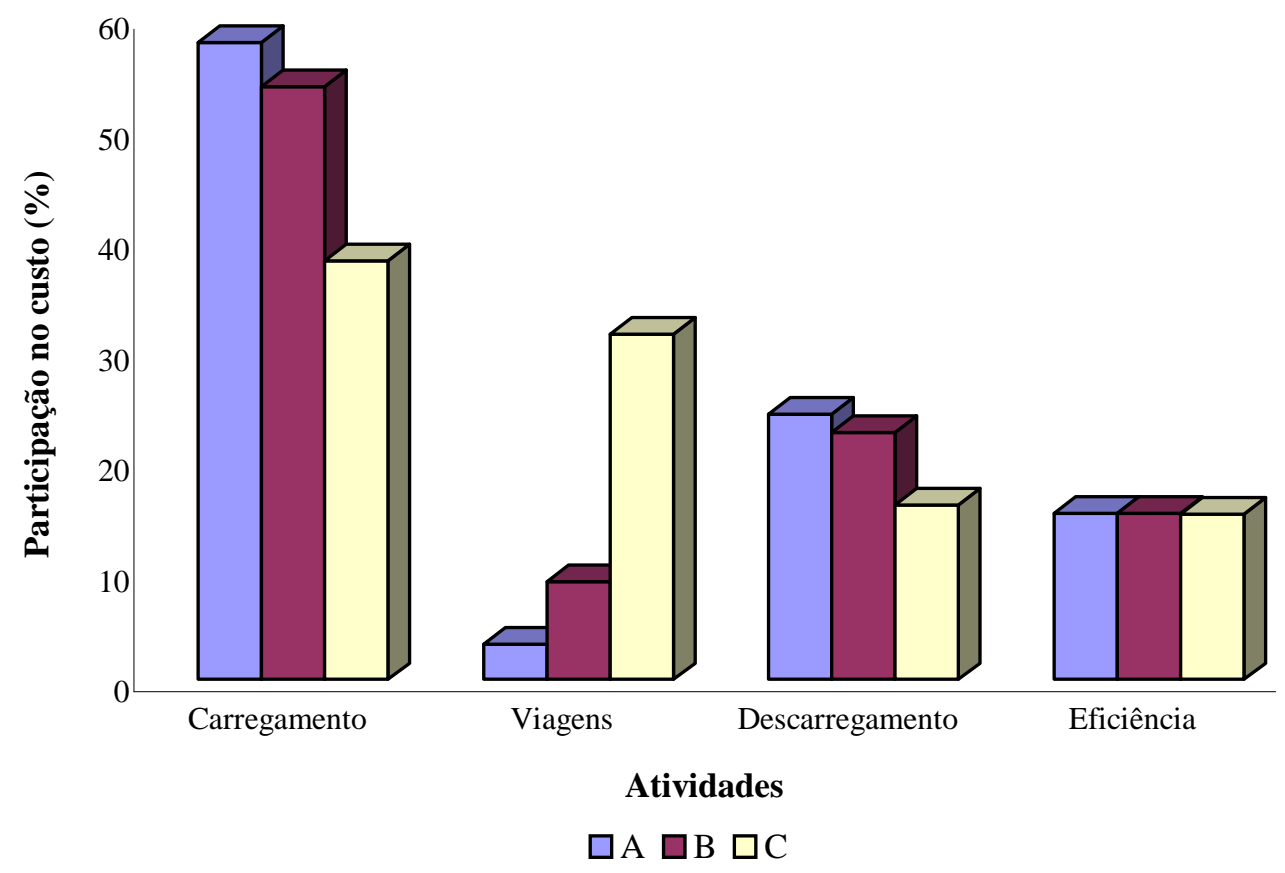

Figura 25 - Comparativo entre o consumo de recursos pelas atividades de transbordo 
Em A, mais de $60 \%$ dos custos foram de responsabilidade do carregamento. Na seqüência, o descarregamento respondeu por $24 \%$ e a eficiência por $15 \%$. Com o posicionamento dos veículos à maiores distâncias, os tempos desprendidos nas viagens de ida e de volta tiveram suas contribuições na duração dos ciclos incrementada, o que fez com que os custos dessas atividades se elevassem. Como, percentualmente, menos tempo é gasto pelas carretas em carga/descarga, os custos dessas atividades reduziram-se consideravelmente. Uma vez que a eficiência gerencial foi mantida constante, nos três cenários, e ela representa um fator de acréscimo ao tempo de duração dos ciclos, sua participação percentual também se manteve constante, na casa dos 15\%.

\subsubsection{Transporte}

Os cálculos do custeio $A B C$ para os dois direcionadores utilizados na alocação dos recursos são mostrados na Tabela 10.

Tabela 10. Direcionadores de recurso e custos envolvidos com o transporte da produção, cenários A, B e C

\begin{tabular}{lrrrrrr}
\hline Cenário & Tipo & Quantidade & $\begin{array}{r}\text { Custo unit. } \\
(R \$)\end{array}$ & $\begin{array}{r}\text { Valor Safra } \\
(R \$)\end{array}$ & $\begin{array}{r}\text { Particip. } \\
(\%)\end{array}$ & $\begin{array}{r}\text { Total Safra } \\
(R \$)\end{array}$ \\
\hline A & & & 00,06 & 901,0 & 8,9 & 10138,3 \\
& Tkm & 16109,9 & 03,71 & 9237,3 & 91,1 & \\
B & Ton & 2491,9 & 00,06 & 7156,9 & 20,9 & 34280,3 \\
& Ton & 74776,0 & 03,63 & 27123,5 & 79,1 & \\
C & Tkm & 1943361,0 & 00,09 & 172675,3 & 47,3 & 365013,7 \\
& Ton & 37380,0 & 05,15 & 192338,5 & 52,7 & \\
\hline
\end{tabular}

O objetivo do custeio baseado em atividades é garantir uma melhor alocação dos custos aos produtos ou serviços, bem como uma gestão mais racional das operações. Por meio de sua aplicação, tornou-se possível compreender a estrutura de custos dos subsistemas com base em suas etapas principais. As etapas de viagem de ida/volta foram alocadas aos recursos por meio do direcionador momento de transporte (Tkm), enquanto 
que, as etapas de carga e descarga dos veículos, pelo direcionador quantidade de carga transportada (Ton).

A Tabela 10 mostra que as atividades de carga/descarga foram as responsáveis pela maior parcela dos custos de transporte, em todos os sistemas. Mesmo em C elas responderam por mais da metade dos custos de transporte. Em A, a importância relativa dessas foi maior, respondendo por mais de $90 \%$ dos recursos consumidos. De fato, nesse cenário, a tonelagem-quilometro a ser vencida pelos veículos foi pequena, uma vez que tanto a produção a ser transportada quanto a distância a ser percorrida foram reduzidas.

À medida que a distância nas rotas foi elevada, a participação dos custos de carga e descarga nos cenários reduziu-se, em virtude das maiores proporções assumidas pelos custos de viagem, ou variáveis. Dentre eles, o combustível, os lubrificantes e as taxas de manutenção. Uma vez que a produção em C percorreu uma distância substancialmente superior do que nos dois primeiros casos, os custos de carregamento e descarregamento foram menos expressivos, em termos relativos, quando comparados com os custos dos deslocamentos. A desagregação do custo por recurso e por atividade, para o cenário B, é apresentada na Tabela 11.

Como no cenário B as rotas ainda são caracterizadas por curtas distâncias, na média 6,4 km, as atividades de maior consumo de recursos foram as de carga/descarga, em conjunto com os tempos improdutivos por ineficiência. Nesse, o carregamento dos veículos foi feito em 2,4 horas. Nesse tempo, influenciaram a capacidade útil de carga dos veículos, de 17 toneladas, e a capacidade de transbordo de produção proporcionada pelo sistema, de 7,1 toneladas por hora. Embora exista discrepância nas distâncias dos talhões, com alguns muito próximos, na faixa de 2 quilômetros, e outros mais distantes, na de 13 quilômetros, na média, as viagens de ida/volta ao longo da safra somam, juntas, por ciclo, 0,5 h. Essa diferença no tempo de duração das atividades acarretou maiores custos fixos dos que variáveis. 
Tabela 11. Relatório Custos $A B C$ - Desagregação dos custos por recurso e por atividade (R\$), Cenário B

\begin{tabular}{lrrrrrr}
\hline $\begin{array}{l}\text { Atividade } \rightarrow \\
\downarrow \text { Recurso }\end{array}$ & Carreg. & Viagem & Viagem & Descarreg. & Eficiência & Total \\
Depreciação & 2363,0 & 127,1 & 181,0 & 819,4 & 616,1 & 4106,7 \\
Juros & 5143,0 & 276,6 & 397,0 & 1782,9 & 1340,7 & 8940,3 \\
ALST & 2408,0 & 129,4 & 184,9 & 834,5 & 627,6 & 4184,6 \\
Manutenção & - & 437,4 & 437,0 & - & - & 874,4 \\
Pneus & - & 453,5 & 452,0 & - & - & 905,5 \\
Combustível & - & 1539,6 & 1541,0 & - & - & 3080,6 \\
Lubrificante & - & 43,1 & 43,0 & - & - & 86,1 \\
Motorista & 6984,0 & 375,5 & 535,0 & 2420,7 & 1820,3 & 12135,6 \\
Total & 16898,0 & 3382,5 & 3770,9 & 5857,6 & 4404,9 & 34314,0 \\
\hline
\end{tabular}

\subsection{Desempenho de maquinaria: análises de comportamento e interações}

Análises de sensibilidade internas foram realizadas nos subsistemas colheita, transbordo e transporte visando identificar os parâmetros de maior potencial de redução de custo e de melhoria de desempenho operacional. As análises de comportamento e de inter-relacionamento entre os parâmetros de destaque, por subsistema, são apresentadas a seguir.

\subsubsection{Colheita}

\subsubsection{Capacidade efetiva}

A capacidade efetiva, ou potencial, de colhedoras de grãos, é função de três fatores: largura de plataforma, velocidade de colheita e produtividade dos talhões. A Figura 26 apresenta as curvas de velocidade versus capacidade efetiva e versus custo, ajustadas por simulações sucessivas. A plataforma e a produtividade foram mantidas constantes e a velocidade foi ajustada para o intervalo entre 5 e $12 \mathrm{~km} \cdot \mathrm{h}^{-1}$, faixa essa tipicamente utilizada na colheita de soja. 


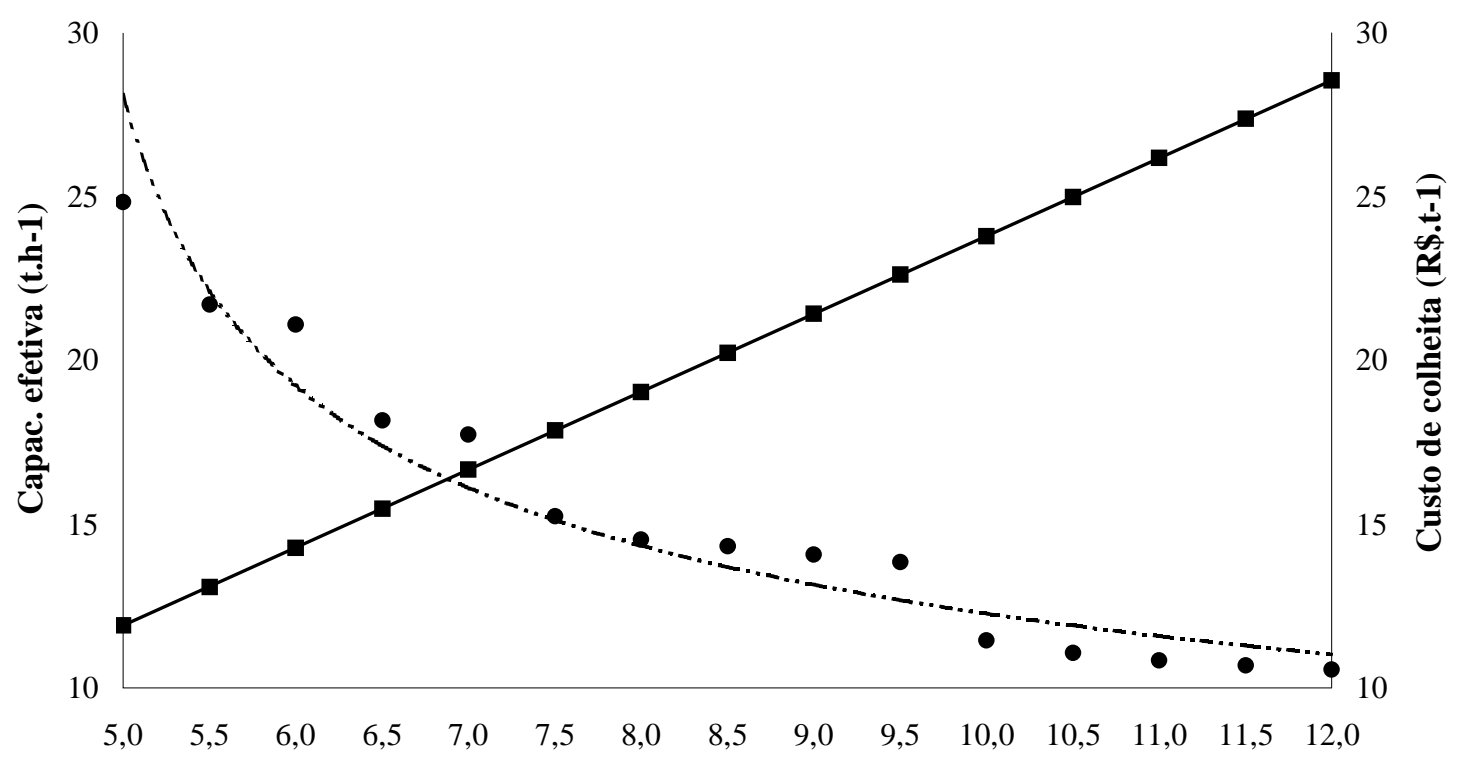

Velocidade de colheita (km.h-1)

- Capac. Efetiva - Custo de colheita ——Capac. Efetiva - - - C Custo de colheita

Figura 26 - Frota de Colhedoras - curvas de comportamento de capacidade efetiva e de custo mediante variações em suas velocidades de colheita

A capacidade efetiva da maquinaria foi direta e linearmente proporcional às velocidades com as quais as colhedoras foram operadas. Incrementos de velocidade refletiram-se diretamente em capacidade efetiva. Contudo, a mesma tendência linear não foi verificada quanto aos custos. Reduções de velocidade sempre geraram elevações de custo, mas em diferentes taxas. Para menores valores, o custo da operação se elevou consideravelmente. A diminuição em $1 \mathrm{~km} \cdot \mathrm{h}^{-1}$, de 7 para 6, elevou os custos em 20\%, enquanto que, de 9,5 para 8,5, em 3,5\%. A diferença entre 6 e $9 \mathrm{~km} . \mathrm{h}^{-1}$ foi de $50 \%$.

É importante destacar que existem fatores que limitam a velocidade das máquinas colhedoras, e que fogem ao domínio do tomador de decisão. O relevo dos talhões, as heterogeneidades de superfície do solo e a produtividade das culturas estão entre eles. Além disso, existem as limitações impostas pelos sistemas de trilha, separação e limpeza, pelo maior nível de perdas de grãos que ocorre quando maiores 
velocidades são praticadas. A velocidade de operação ótima passa pelo balanceamento da relação custo/benefício entre esses fatores.

Caso a velocidade máxima tenha sido alcançada, e maiores potenciais continuem a ser almejados, a alternativa é o uso de plataformas de maior porte. Um comparativo entre custos de colhedoras equipadas com seis distintas plataformas, operando a uma mesma velocidade, é feito pela Figura 27. Entre as plataformas (PL) de 14 e de 23', , uma única colhedora foi utilizada nas simulações. A partir da de 25', uma outra, maior, foi selecionada, a fim de comportar o aumento de fluxo de produto no interior da máquina.

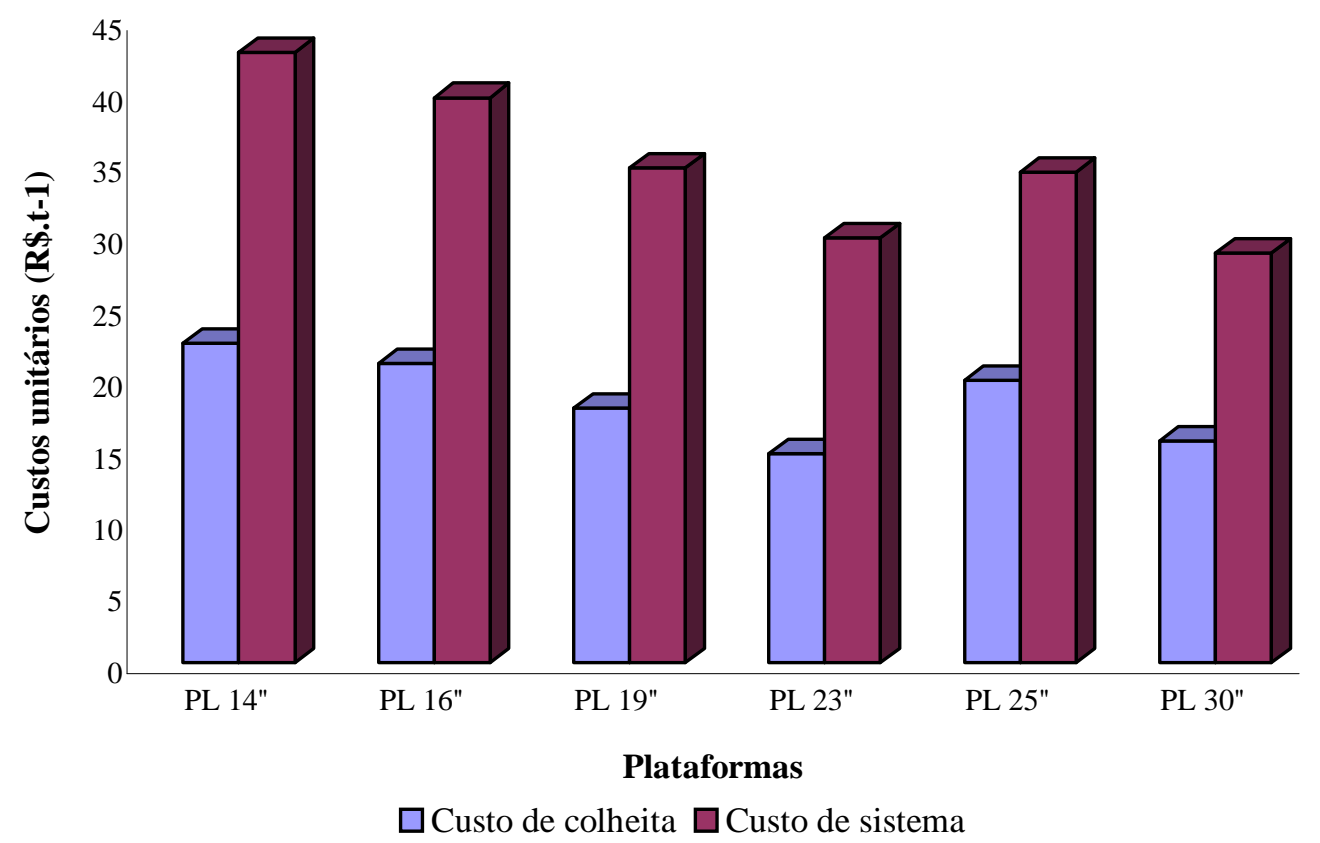

Figura 27 - Frota de colhedoras - custos de colheita para plataformas de seis diferentes tamanhos

Embora o valor das plataformas de maior largura seja superior, sua utilização reduziu os custos de forma significativa. Utilizar a plataforma de 23"' foi 17\% mais econômico do que a de 19’', em relação ao sistema, e 22\% em relação à colheita. 
Como, para a plataforma de 25', uma colhedora de maior valor foi selecionada, ambos os custos tiveram seus patamares elevados, por ocasião de sua seleção. Contudo, considerando os mesmos valores de eficiência, da forma como foi feita a Figura 36, a colheita realizada com uma colhedora equipada com uma plataforma de 25', de valor de aquisição $\mathrm{R} \$ 580.000,00$, em termos de sistema, demonstrou custos semelhantes àquela realizada com unidades de $\mathrm{R} \$ 390.000,00$, de menor capacidade. Isso ocorreu porque, com o aumento das capacidades efetivas individuais, um menor número de colhedoras foi necessário para que a produção fosse retirada. Além disso, os custos de transbordo e de transporte também foram reduzidos, em reflexo à maior capacidade de retirada. $\mathrm{O}$ desempenho de todo o sistema foi regido pelo desempenho das colhedoras.

\subsubsection{Formato de talhão}

A eficiência de talhão foi inserida na rotina como um dos três fatores que, em conjunto, determinam a eficiência de campo da frota. Os outros dois são as eficiências de operação e de gerência.

Nas simulações, foi agendada a colheita de 16 talhões, cada um deles possuindo, como uma de suas características, um índice de eficiência, representativo do seu grau de adequação à operação da maquinaria. A Figura 28 mostra a diferença percentual dos seus custos de colheita em relação ao custo médio demonstrado ao longo da safra, de $\mathrm{R} \$ \mathrm{t}^{-1} 14,62$.

Os custos de retirada de produção variaram sobremaneira no decorrer da colheita. Uma vez que a capacidade efetiva e os demais fatores de eficiência foram mantidos constantes para todos os talhões, a variação apresentada pelo custo foi função exclusiva dos índices de eficiência dos talhões. Naqueles nos quais os índices foram inferiores, os custos elevaram-se consideravelmente, devido à redução de capacidade da maquinaria. Isso porque, em talhões ineficientes, o tempo requerido nas manobras de cabeceira, na colheita de lados irregulares e de ângulos agudos, é maior. Como as máquinas passam menos tempo colhendo, a frota tem sua capacidade reduzida.

Em T21, o custo foi 23\% superior do que a média no período. Esse foi um talhão de índice 0,78 , o menor de todos. Quanto mais adequado foi o talhão à operação 
da maquinaria, menor foi o intervalo entre os descarregamentos e, assim, maior foi a capacidade da frota. Em T06, de índice 1,10, o custo foi 13,6\% menor que a média.

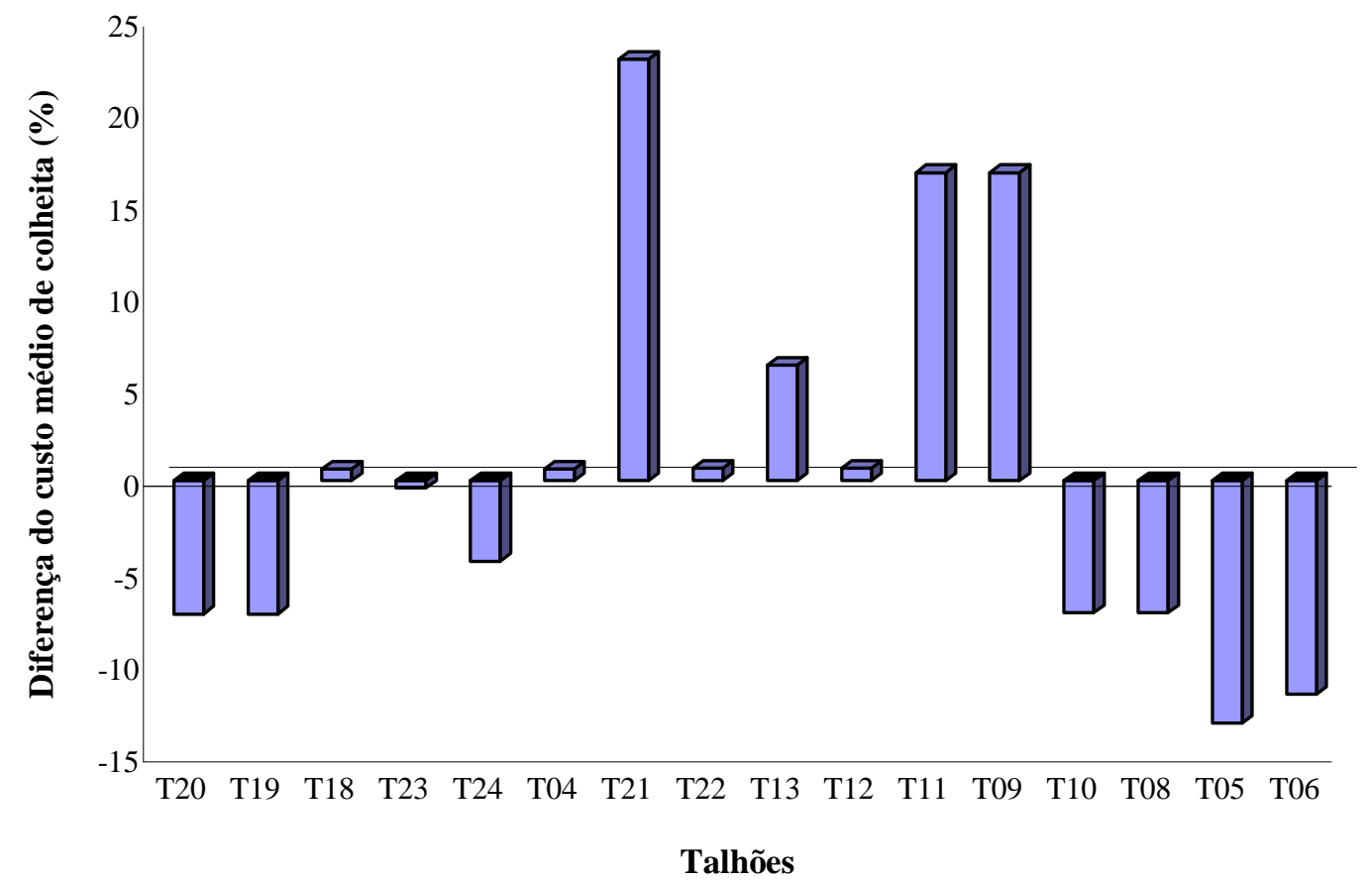

Figura 28 - Diferença entre os custos de colheita nos dezesseis talhões simulados e o custo médio no período

O formato de talhão ideal, é descrito por Witney (1988) como sendo retangular, de largura igual à da plataforma e de longo comprimento. Esse tornaria desnecessária a realização de manobras de cabeceira, e maximizaria o nível de eficiência da operação. As colhedoras permaneceriam apenas retirando a produção. Entretanto, é sabido que, na prática, tal condição ideal é inviável, e não pode ser obtida.

Uma alternativa interessante é programar a colheita dos talhões de pior formato para as épocas de maior tempo disponível. Essas normalmente ocorrem ao final da safra, a partir do mês de abril, quando o período típico de maiores precipitações se encerra. Com o tempo disponível maior, um menor número de equipamentos se faria necessário. 


\subsubsection{Níveis de eficiência}

A eficiência reduziu tão consideravelmente os custos de colheita e de sistema porque ela é, em conjunto com a capacidade efetiva, o fator que rege a taxa de retirada de produção pelas colhedoras, em quantidade por unidade de tempo. Uma vez que tratase sobretudo de uma taxa de aproveitamento, colhedoras de grande capacidade potencial podem não demonstra-las na prática, caso baixos níveis de eficiência forem praticados.

De fato, para uma mesma capacidade efetiva, quanto maior for o nível de eficiência, e quanto mais adequado for o formato dos talhões à operação da maquinaria, maior será a capacidade real de colheita da frota, em termos de produção e número de descarregamentos por dia. A Figura 29 mostra exatamente esse comportamento. Nela, é apresentado o número de ciclos realizados por cada colhedora ao longo da colheita da safra, de quatro semanas de duração. Simultaneamente, o número de horas-máquina necessário para a totalização da operação é também apresentado.

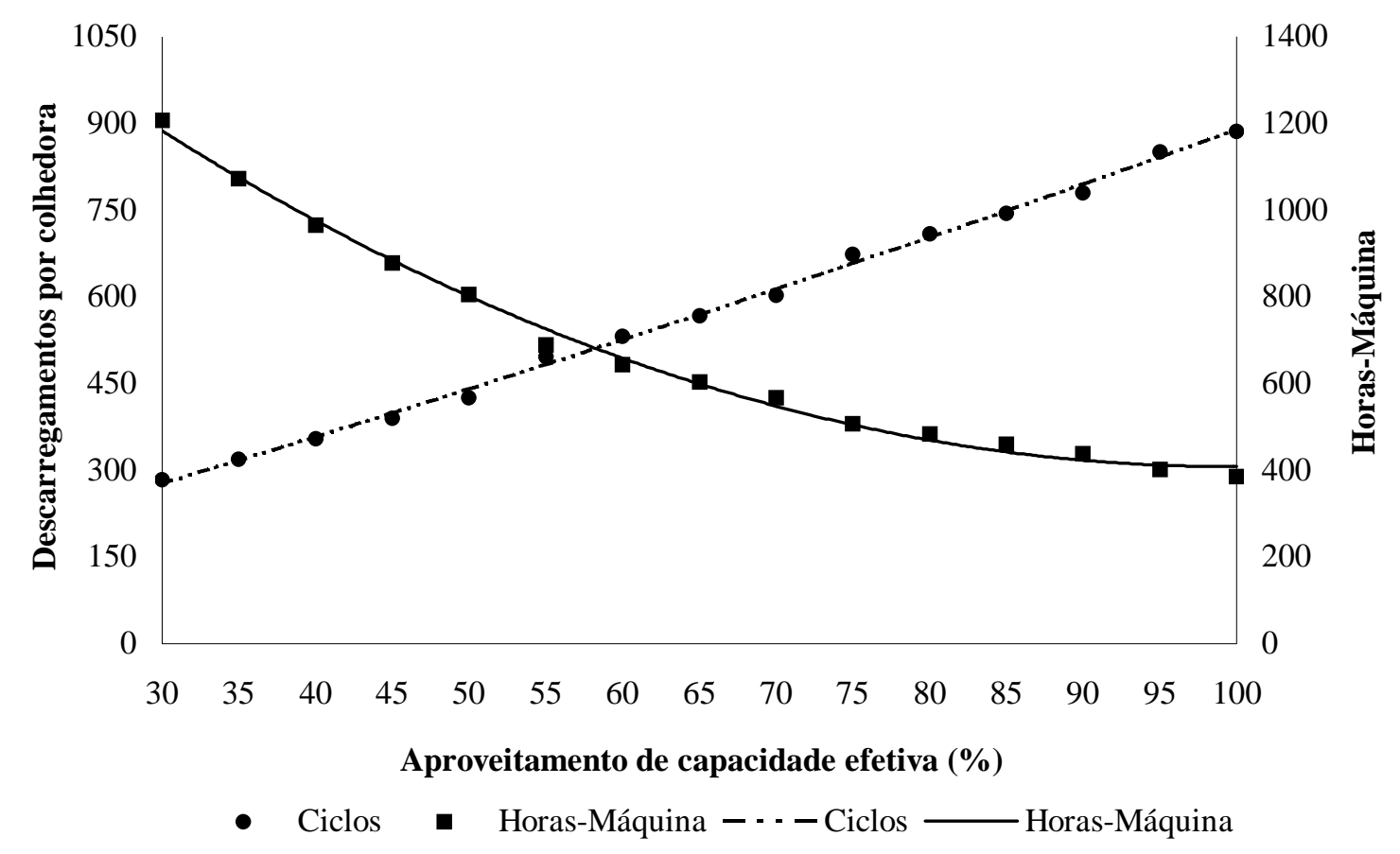

Figura 29 - Número de ciclos por colhedora e de horas-máquina necessárias à totalização da operação, para uma faixa de eficiência variando de 30 a 100\% 
O número de ciclos que cada unidade foi capaz de realizar ao longo da safra demonstrou, tal como a taxa de retirada, ser direta e linearmente proporcional ao nível de eficiência. Quanto maior foi esse, maior foi o número de descarregamentos de cada colhedora. O número de horas-máquina comportou-se de forma inversa, seguindo uma curva assintota. À medida que a capacidade foi aprimorada, o número necessário ao cumprimento da meta reduziu-se continuamente. De 60 a $70 \%$, a diferença foi de $15 \%$.

É importante destacar que o número total de descarregamentos a ser realizado pela frota, de forma a permitir a retirada de toda a produção, ao longo da safra, não é alterado, porque ele independe da eficiência. Os fatores que o determinam são apenas a produção e o volume dos graneleiros. Assim, quanto mais descarregamentos, ou ciclos, cada máquina for capaz de realizar, menos máquinas são necessárias à retirada da produção. A redução no número de colhedoras e o incremento do custo de sistema frente a alterações de eficiência são ilustradas pela Figura 30. O índice de 100\% representa um sistema ideal, no qual nenhum tempo extra é incluído ao ciclo das colhedoras, sendo por isso utilizado como referência.

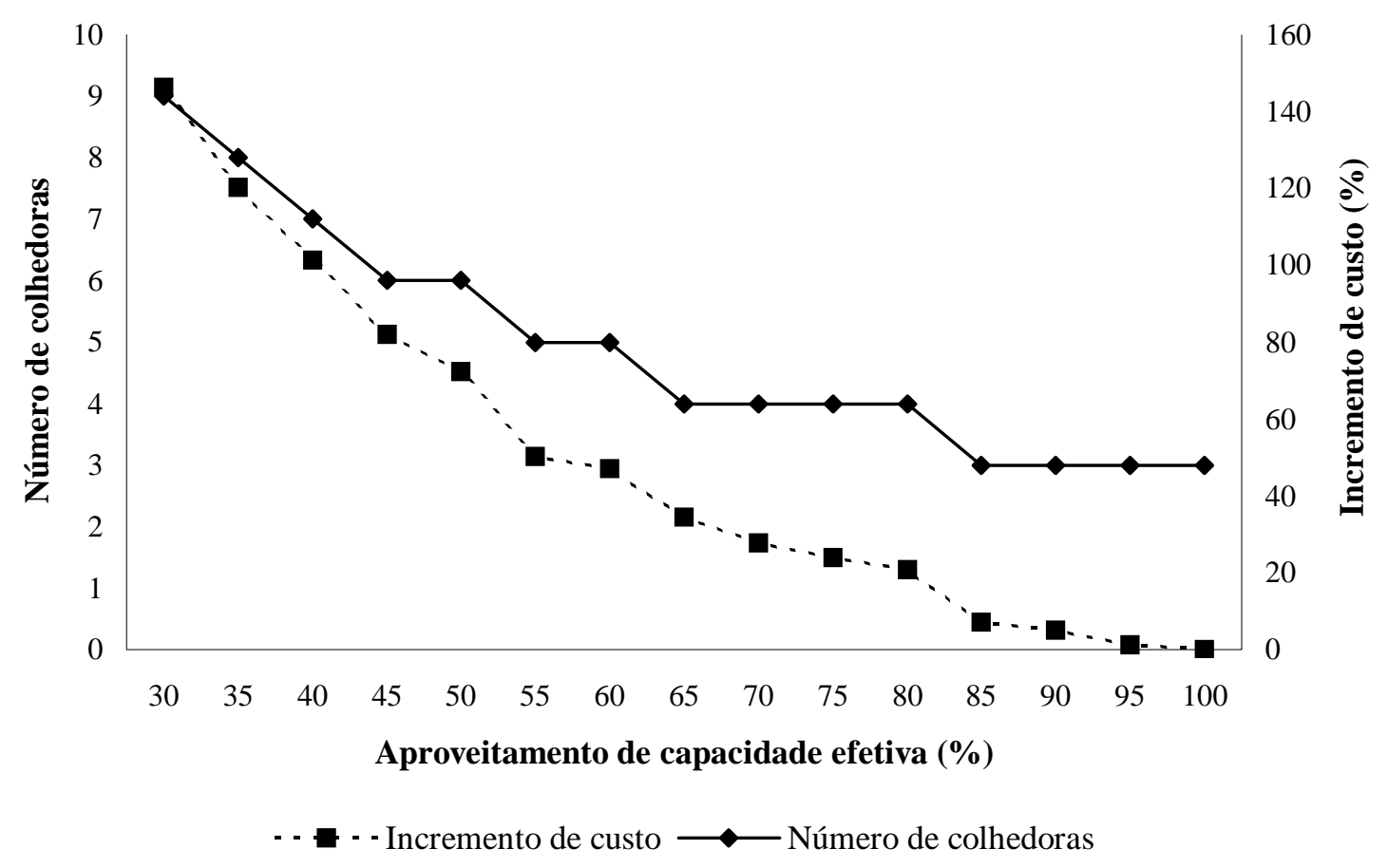


Figura 30 - Número de colhedoras necessário à totalização da operação, para uma faixa de eficiência variando de 30 a 100\%

Em sistemas de baixa eficiência, o número de colhedoras requerido elevou-se substancialmente. Em um sistema de eficiência 75\%, 4 máquinas foram necessárias. Em contrapartida, caso esse apresentasse uma eficiência da ordem de 50\%, e o interesse fosse colher toda a produção previamente programada no tempo previsto, o número

subiria para 6. Caso a frota fosse limitada, o que aconteceria é que o sistema não seria capaz de colher a produção prevista, a meta não seria atingida e a perda por pontualidade aumentaria. Nota-se que os efeitos nos custos decorrentes de um aprimoramento de $10 \%$ na eficiência é maior em sistemas de maior ineficiência. Nesses, pequenas alterações nos índices geram alterações mais significativas do que em sistemas mais eficientes. Para o cenário B (eficiência de 70\%), um incremento de 10\% reduziu os custos em 5,4\%, o equivalente à R\$ 1,60 por tonelada colhida. Contudo, a mesma alteração, em um sistema de eficiência 40\% ocasionou reduções da ordem de 21\% (R \$ 9,90 por tonelada).

\subsubsection{Utilização anual}

O incremento do custo de colheita frente ao número de horas de utilização anual das colhedoras é ilustrado pela curva apresenta pela Figura 31, com a utilização das máquinas avaliada na faixa de 50 a 950 h. 


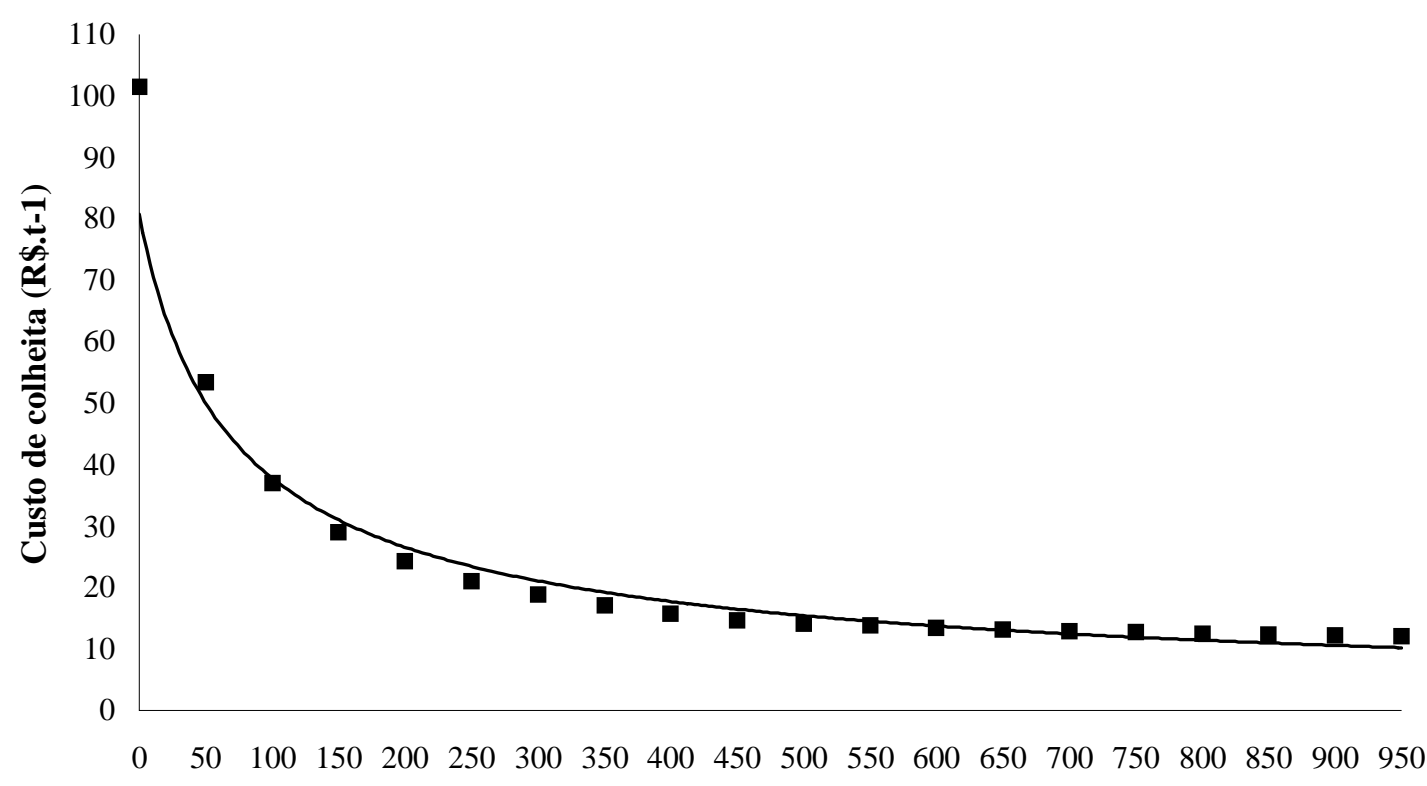

Utilização anual por colhedora (h)

Figura 31 - Incremento do custo de colheita como função do número de horas-ano de utilização da frota

Baixas utilizações elevaram por demasia os encargos fixos horários das máquinas, elevando os custos de retirada da produção. À medida que o número de horasano simulado foi elevado, os custos reduziram-se consideravelmente. De 300 para 500 h, a redução foi de 30\%. Após essa marca, as reduções se mantiveram, embora a uma taxa inferior. Quanto maior foi a utilização, mais econômica se tornou a operação.

\subsubsection{Transbordo}

A análise de sensibilidade interna (Figura 20) demonstrou que, em função da configuração, os parâmetros afetaram a composição dos custos de uma forma diferente. Em A, característico de pequenas produções e distâncias reduzidas entre colhedoras e veículos, os fatores de maior participação foram a capacidade de retirada das colhedoras, a eficiência com a qual o subsistema é gerenciado e a utilização anual dos tratores. À medida que as produções se elevaram, e houve a distância percorrida foi maior, características como a capacidade de carga útil das carretas graneleiras, as velocidades 
de deslocamento nas viagens e o ponto de posicionamento assumiram maiores significâncias.

De um modo geral, o distanciamento entre veículos e colhedoras mostrou-se mais significativo em sistemas de maior produção. Por outro lado, em todos os cenários, a capacidade de retirada das colhedoras demonstrou ser um dos principais potenciais de redução de custo, razão pela qual sua influencia no desempenho do subsistema é discutida na seqüência. O parâmetro eficiência, por ter um comportamento semelhante àquele apresentado para as colhedoras, não foi analisado.

\subsubsection{Capacidade de colheita}

A Figura 32 mostra as curvas de comportamento do tempo de carregamento e da capacidade de transbordo das carretas graneleiras em função da capacidade das colhedoras de retirar a produção. Essa foi variada de 5 a 20 t.h ${ }^{-1}$, para o cenário B.

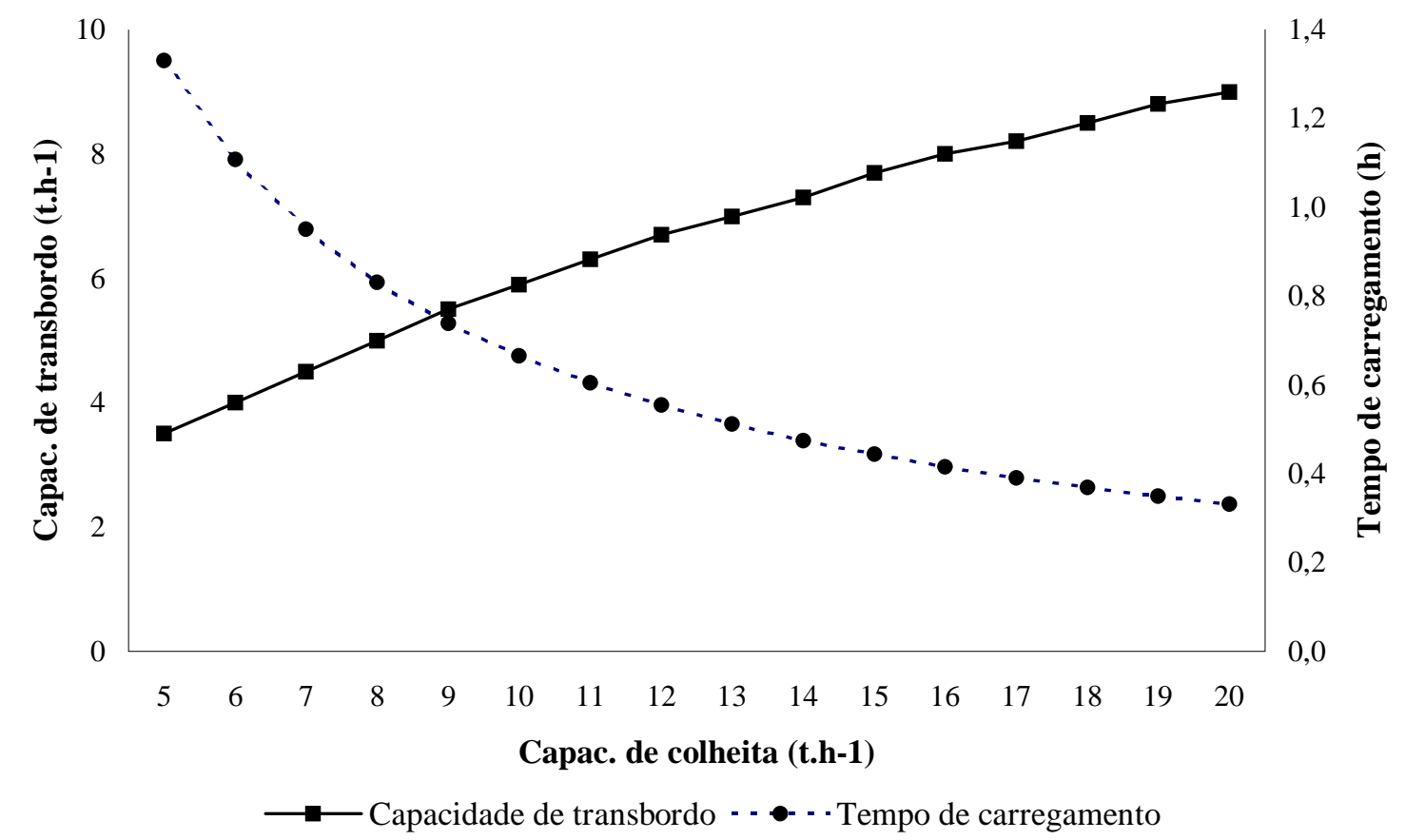

Figura 32 - Comportamento da capacidade de transbordo e do tempo de carregamento das carretas graneleiras frente à variações na capacidade de colheita 
A capacidade das carretas de transbordar a produção demonstrou ser diretamente proporcional à capacidade das colhedoras em retira-la. De fato, as carretas tiveram os seus tempos de carregamento reduzidos com os aumentos na taxa de colheita. À medida que o tempo de totalização da carga foi menor, suas capacidades de transbordo se elevaram, uma vez que mais tempo se encontrava disponível ao deslocamento efetivo da produção. Por outro lado, nas simulações onde as taxas de retirada foram menores, mais tempo essas permaneceram em espera para a totalização de suas cargas, o que fez com que, dessa forma, seus desempenhos fossem prejudicados.

Como a rotina foi elaborada de modo que os resultados propiciassem a colheita, o transbordo e o transporte de toda a produção previamente programada, o número de carretas, em situações de baixa capacidade de colheita, elevou-se consideravelmente, acarretando aumentos também nos custos de transbordo, conforme apresenta a Figura 33.

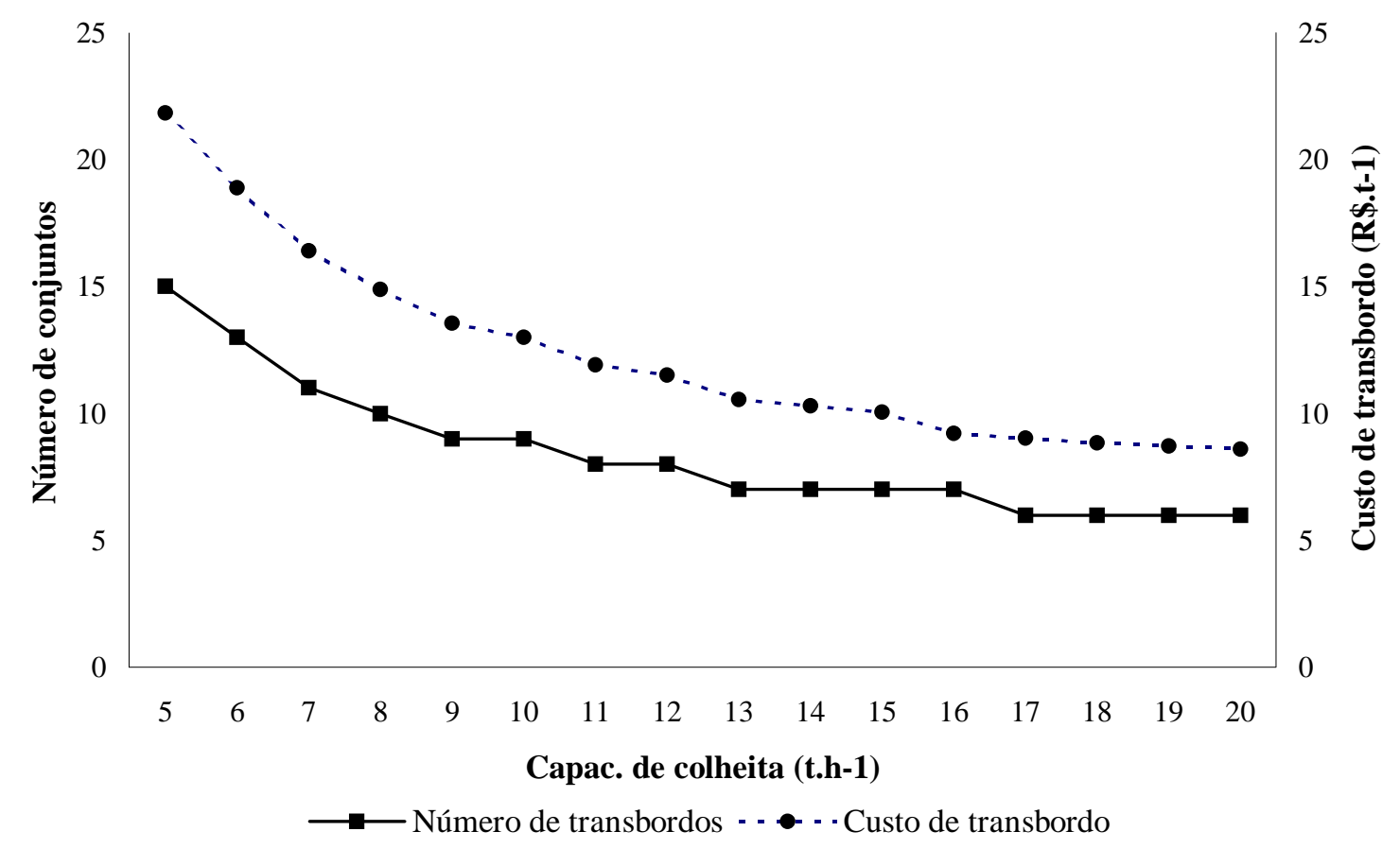

Figura 33 - Comportamento do número e do custo de transbordo dos conjuntos trator e carreta graneleira frente à variações na capacidade de colheita 
Assim, caso a capacidade de colheita fosse de $5 \mathrm{t} . \mathrm{h}^{-1}$, e mesmo assim as $7476 \mathrm{t}$ necessitassem ser colhidas, seriam necessários 15 conjuntos trator e carreta graneleira. A frota, maior, apresentaria o custo de R\$ 22 por tonelada transbordada. À medida que a capacidade das colhedoras foi elevada, o número de conjuntos se reduziu e, por conseqüência, os custos. Naturalmente, os resultados valem para as características dos tratores e das carretas nas simulações. Nessas últimas, a capacidade é de $9300 \mathrm{~L}$.

Pelo outro extremo, se a colheita propiciasse a taxa de retirada de $20 \mathrm{t} \cdot \mathrm{h}^{-1}$, e não 5 , apenas 6 conjuntos seriam necessários, com um custo de frota de R\$ 8 por tonelada. Em contrapartida, caso a frota fosse limitada, como ocorre na maioria das situações, o sistema não seria capaz de transbordar a produção, e meta não seria atingida.

\subsubsection{Posicionamento dos veículos}

As curvas de comportamento das capacidades de transbordo e de transporte do sistema frente ao posicionamento dos veículos são apresentadas pela Figura 34.

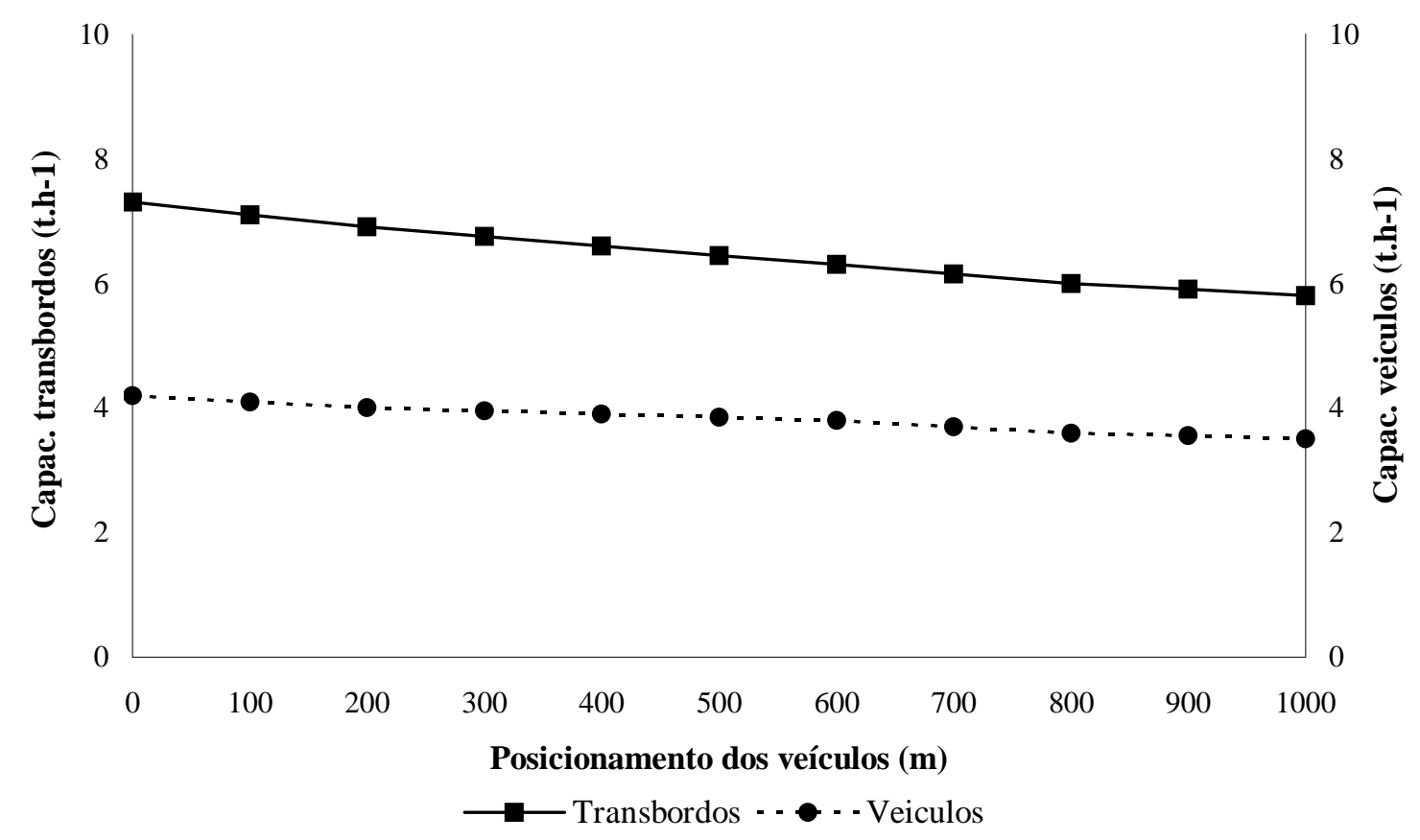

Figura 34 - Redução das capacidades de transbordo e de transporte do sistema frente à alterações no posicionamento dos veículos, sistema com transbordo 
A capacidade das carretas graneleiras mostrou-se inversamente proporcional à distância de posicionamento dos veículos. Quanto maior foi o distanciamento desses últimos, menos toneladas por hora os conjuntos foram capazes de transbordar. Como os veículos, nos cenários base, foram configurados para serem carregados pelas carretas, a redução de sua capacidade refletiu-se diretamente na capacidade de transporte. Isso porque as reduções na capacidade de transbordo geraram aumentos no tempo de carregamento dos veículos. Conforme foi discutido para as colhedoras, essas reduções de desempenho refletiram-se na necessidade de um número maior de equipamentos para o alcance da meta. No caso, tratores, carretas graneleiras e caminhões. É o que mostra a Figura 35. Em conseqüência à esse maior dimensionamento, o custo final da tonelada se elevou. Como quem se deslocou aos veículos foram os transbordos, e não as colhedoras, os custos de colheita se mantiveram constantes.

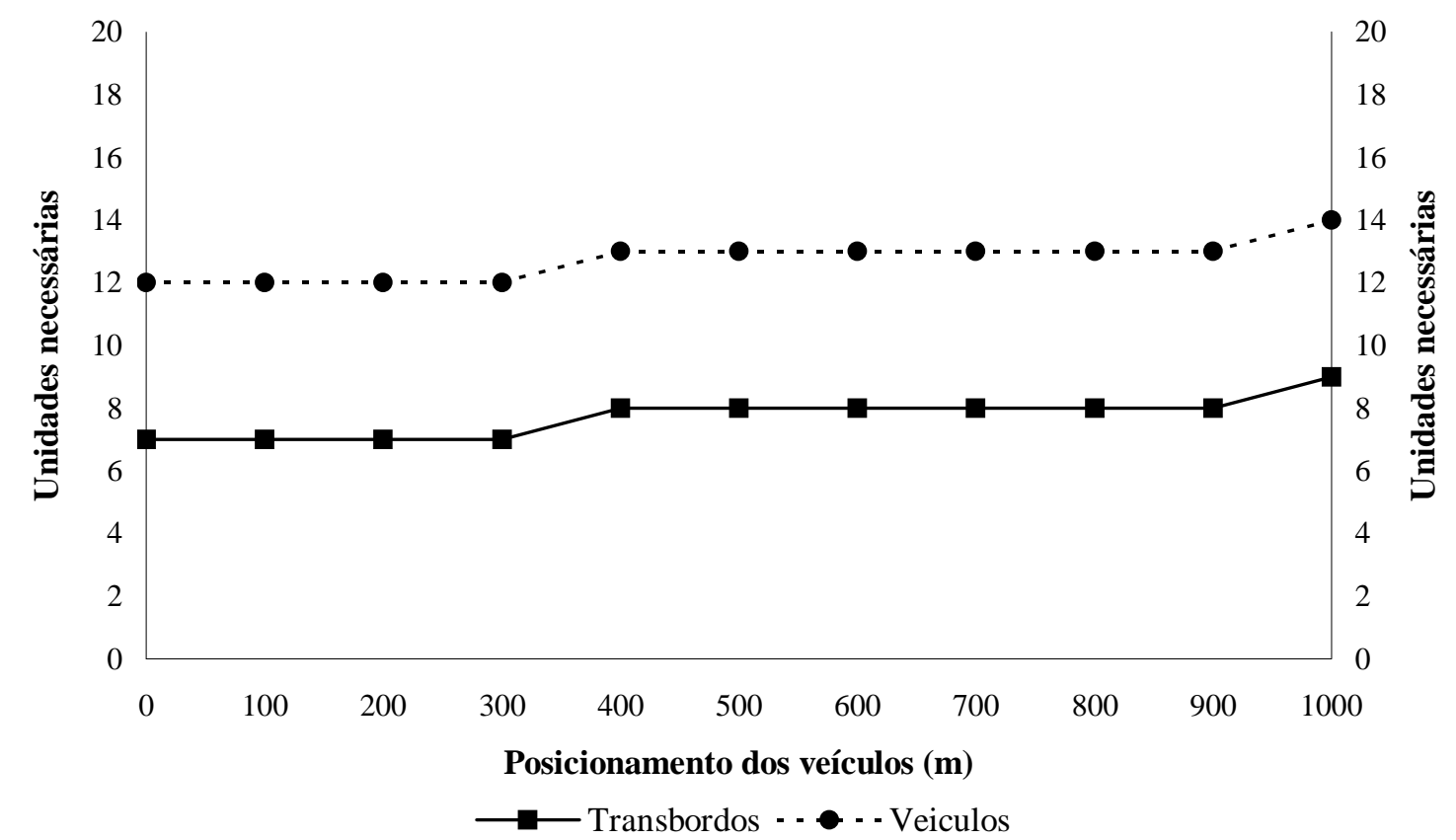

Figura 35 - Variações no número de transbordos e veículos frente a diferentes distâncias de posicionamento dos veículos 


\subsubsection{Transporte}

Nos cenários A e B, os parâmetros de maior potencial para redução de custo foram que os determinam o tempo no qual os veículos permanecem em carregamento, aguardando a totalização de suas cargas. Como esse foi feito pelas carretas graneleiras, a capacidade de transbordo do sistema figurou entre as primeiras posições. Mesmo a capacidade de retirada das colhedoras se mostrou importante. Em contrapartida, em rotas mais longas, fatores como a capacidade de carga útil, a distância e a velocidade foram destaque. A eficiência de gerência demonstrou comportamento semelhante à relativa às colhedoras e, por isso, não foi abordada.

\subsubsection{Tempo de carga e descarga}

Diversas simulações foram realizadas com o intuito de verificar o impacto relativo do tempo de carregamento sobre a distância a ser percorrida pelos veículos. Os resultados são apresentados pela Figura 36. O cenário simulado foi o C, o tempo de carga/descarga de 3h e a velocidade operacional de $50 \mathrm{~km} \cdot \mathrm{h}^{-1}$.

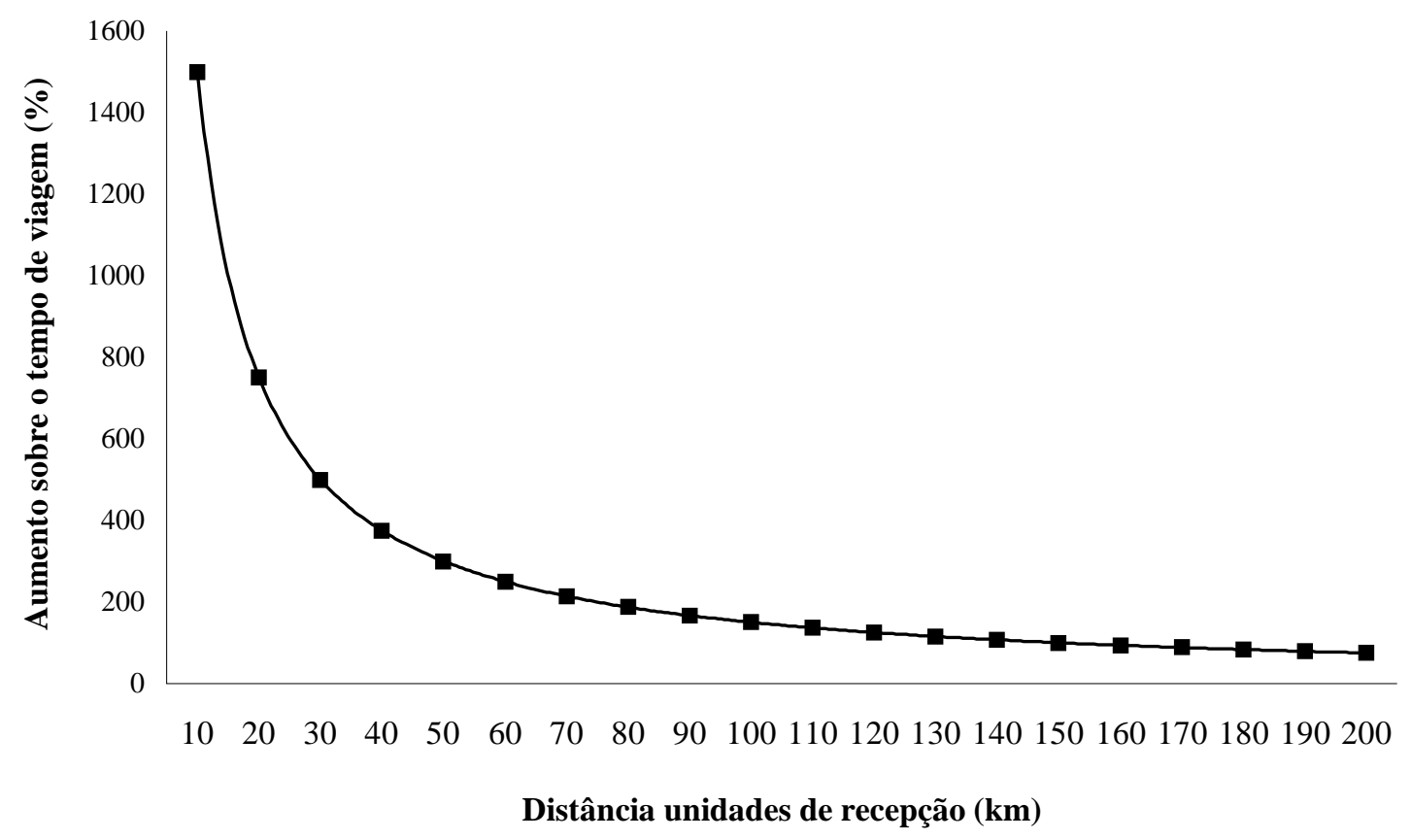

Figura 36 - Impacto relativo do tempo de carga/descarga sobre a distância da rota 
Uma viagem de $100 \mathrm{~km}$ teria seu tempo acrescido $150 \%$ devido a ineficiências nas atividades de carga e descarga. Rotas mais curtas, entretanto, seriam extremamente penalizadas. Uma rota de 30 km (cenário C), apesar de concluída em 40 minutos, seria acrescida de mais três horas para carregamento e descarregamento, um aumento de 470\%. Por outro lado, rotas de maior distância, da ordem de 200 km, seriam percorridas normalmente em quatro horas e sofreriam um acréscimo de apenas 75\%.

Utilizando-se de simulações sucessivas, foi possível determinar a participação do tempo de carregamento e descarregamento como percentual do custo de transporte, para três tipos de rotas principais: curtas (cenário A - 2,2 km), médias (cenário B - 6,5 km) e longas (cenário C - 32,2 km). Os resultados são mostrados pela Figura 37.

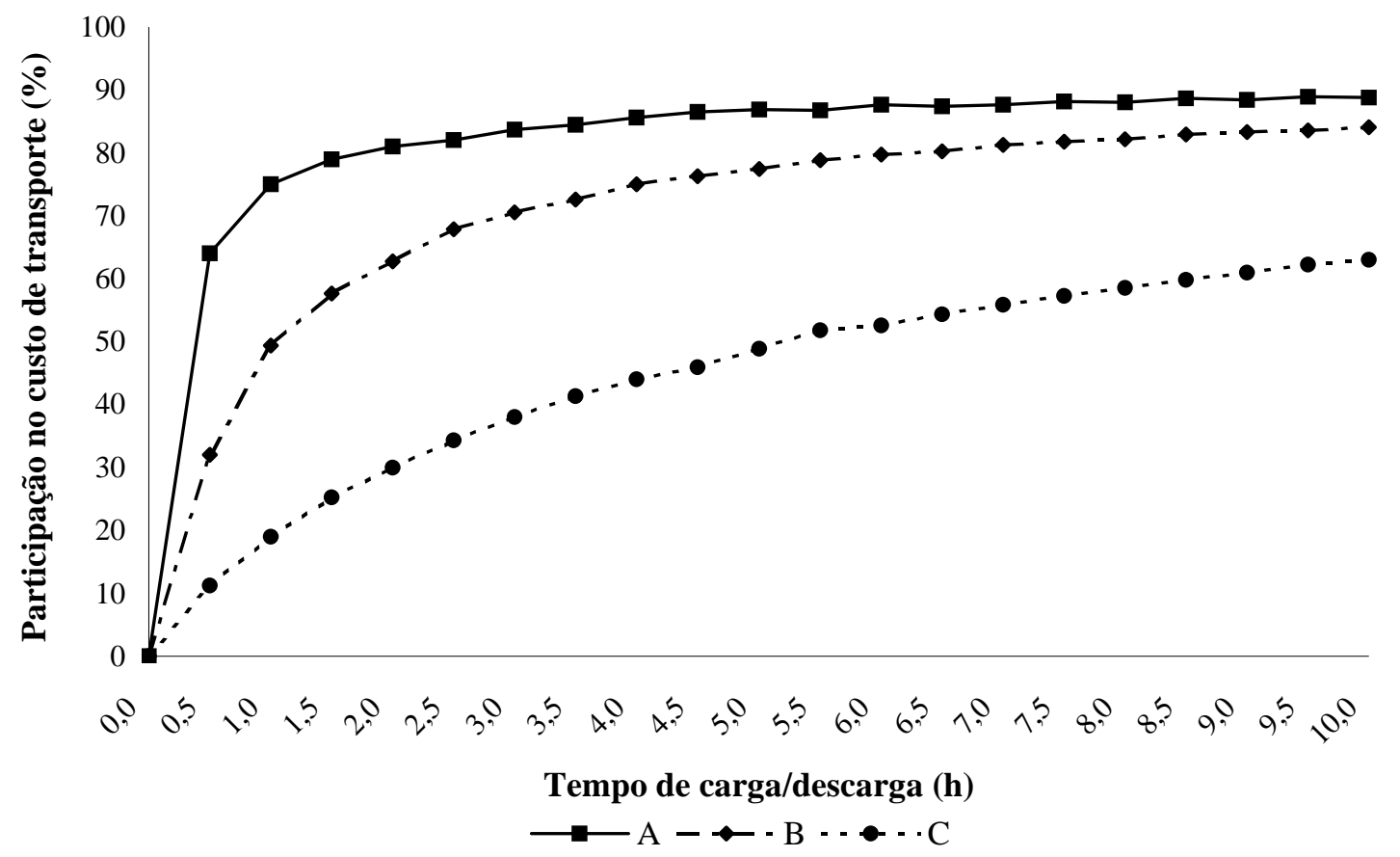

Figura 37 - Participação do tempo de carga e descarga (média de três horas) no custo de transporte - comparativo para rotas curtas, médias e longas

A Figura 37 mostra duas informações importantes. Primeiro, as rotas curtas foram extremamente penalizadas com aumentos do tempo de carga/descarga. O tempo médio de 3 horas fez com que as atividades de carga e descarga respondessem por 84\% 
do custo de transporte. As rotas longas não sofreram um impacto tão grande, visto que o custo da espera foi diluído em um tempo de viagem proporcionalmente maior. Em C, o percentual foi de 38\%. Para rotas médias, o custo se situou em um nível intermediário. No cenário B, equivaleu à $70 \%$.

Em se tratando de sistemas de colheita, o tempo no qual os veículos permanecem em carga é função de suas capacidades úteis e, principalmente, pelo desempenho das máquinas responsáveis por seu carregamento. Caso o sistema utilize carretas graneleiras, esse se refere à taxa, em quantidade por tempo, com que essas transbordam a produção, das colhedoras ao ponto de posicionamento dos veículos. Caso a configuração do sistema não preveja a sua utilização, esse se refere à taxa com que as colhedoras retiram e transportam a produção, desde o ponto do talhão no qual a colheita está sendo realizada até aquele onde os veículos se encontram posicionados. Em ambas as situações, a taxa de retirada da produção pelas colhedoras é o fator determinante. $\mathrm{O}$ seu desempenho influência o desempenho dos demais equipamentos, demonstrando um comportamento sistêmico entre esses três componentes (Figura 38). Vale destacar que maiores capacidades de colheita e transbordo invariavelmente proporcionam menores tempos de espera dos veículos durante a atividade de carregamento. 


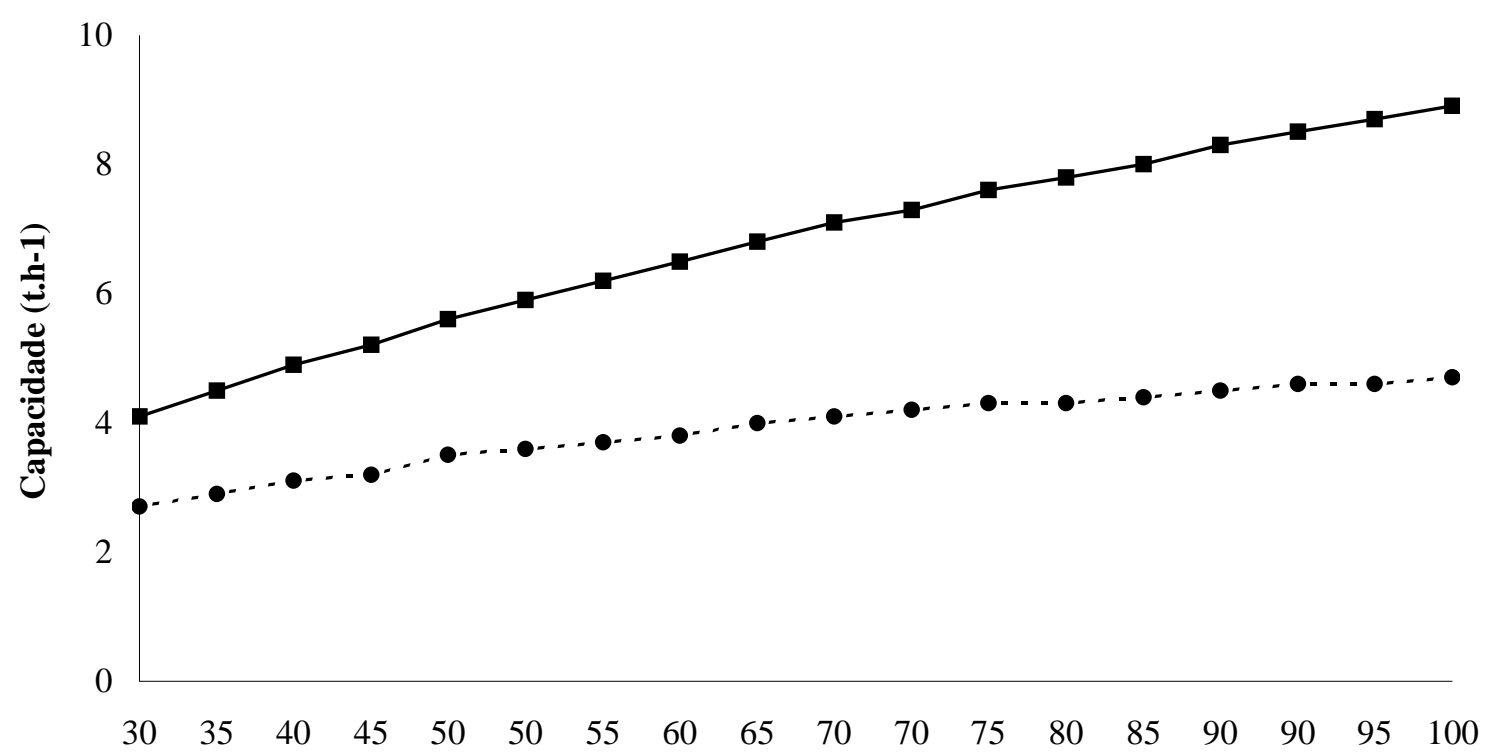

Eficiência de colheita (\%)

-. - . Veiculos $\longrightarrow$ Transbordos

Figura 38 - Curvas de capacidade de transbordo e transporte frente à eficiência de colheita

A curva de aumento do tempo de carga dos veículos em função de reduções percentuais na capacidade de transbordo das carretas graneleiras é mostrada na Figura 39. É notório que o incremento do tempo de carga ocorreu de maneira progressiva e crescente a medida que o sistema teve sua capacidade de transbordo reduzida. Na redução de 55\%, o aumento foi da ordem de $120 \%$. 


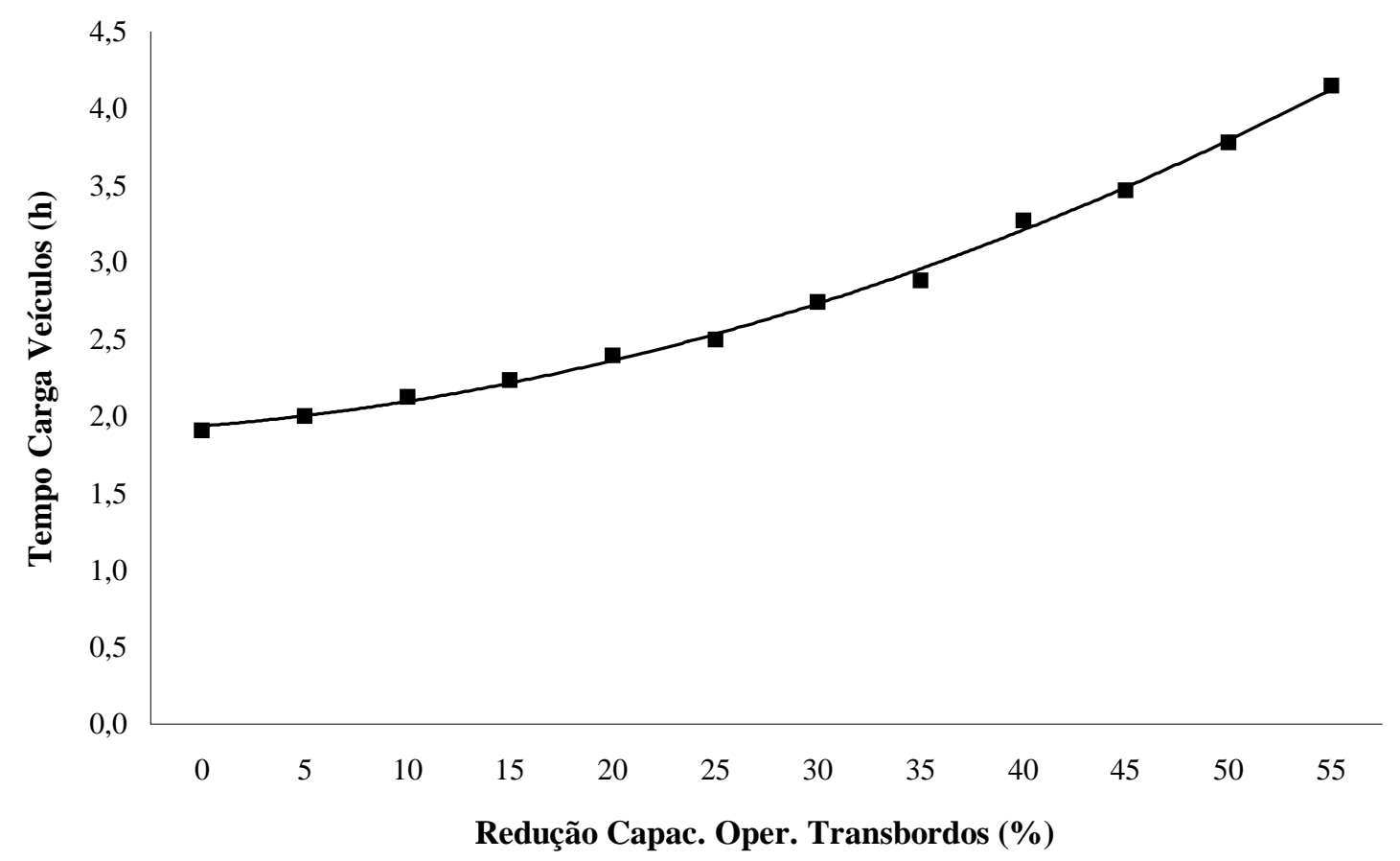

Figura 39 - Incremento do tempo de carregamento de veículos frente à reduções de capacidade de transbordo - sistema com transbordo

Ao contrario do tempo de carregamento, que depende do desempenho dos demais componentes da maquinaria, o tempo de descarga, na maioria das situações, é função do plano de coordenação traçado entre o setor de transporte e o de recepção na empresa. Quanto maiores forem os níveis de ineficiência e de desperdícios de tempo durante essa etapa do ciclo, maiores serão os tempos de espera, com reflexos imediatos no custo de transporte. Em todos as simulações efetuadas, os ganhos potenciais de uma melhor coordenação e programação de carga e descarga foram notórios.

Alterações no tempo de carga e descarga dos veículos produziram diferentes impactos nos sistemas de transporte, em função da distância que caracterizou a rota a ser percorrida. Esse fato pode ser atribuído às duas categorias de custo envolvidos com o transporte da produção. A Figura 40 mostra as participações de ambas no custo de transporte, como reflexo da distância das rotas. 


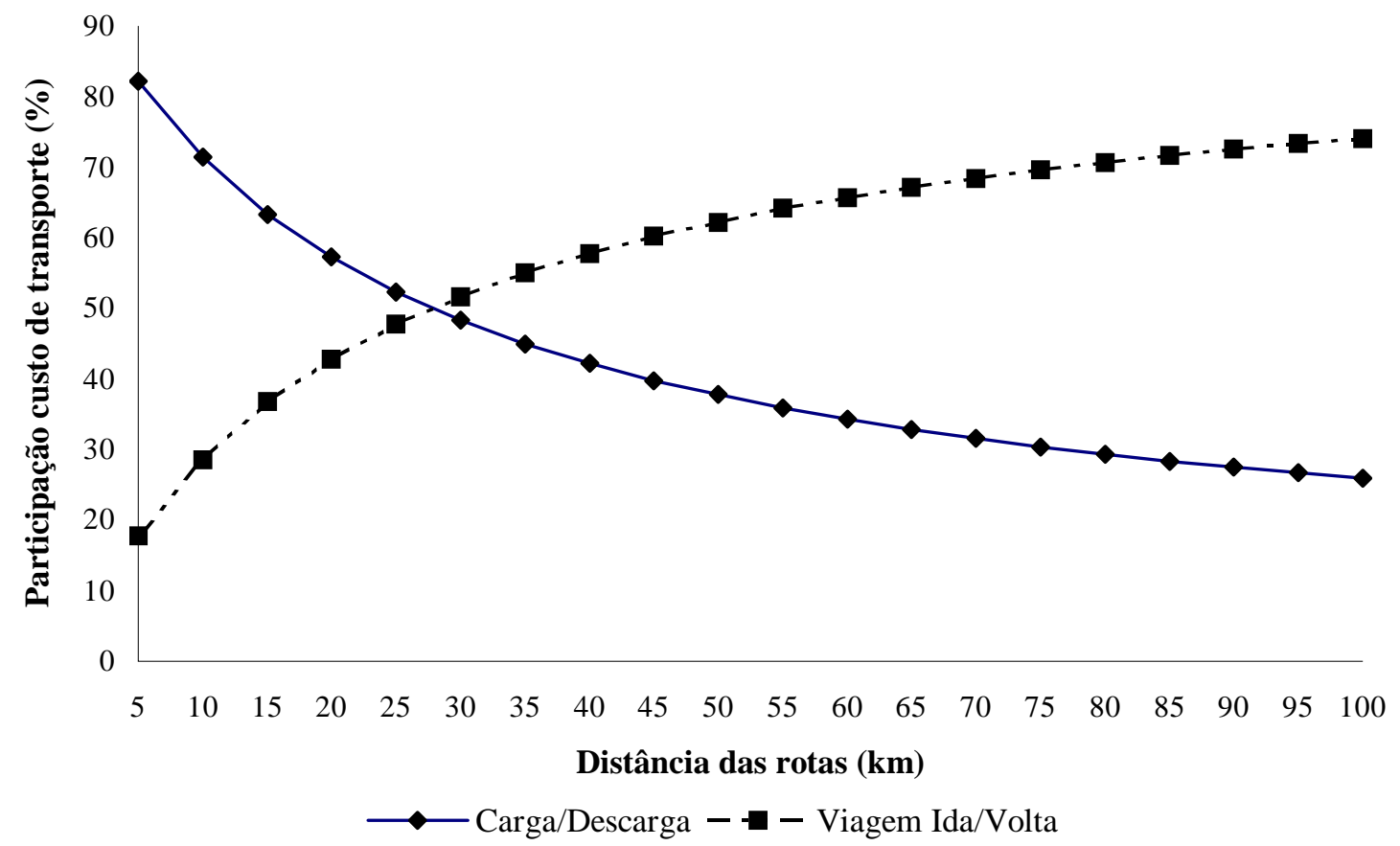

Figura 40 - Variações na participação das duas categorias de custo de transporte em função da distância

O custo variável, característico das etapas de deslocamento, cresceu em ritmo decrescente à medida que aumentou o tamanho das rotas, ao passo que o custo de duração, incidente sobre os tempos de carga e descarga, demonstrou maior impacto sobre as rotas curtas. De uma forma geral, quanto mais longa foi a rota, maior foi a participação do custo variável sobre o custo total. Por outro lado, o custo de carga e descarga tornou-se mais importante quanto maior foi a razão entre o tempo consumido nas atividades de carregamento e descarregamento e o tempo de viagem.

\subsubsection{Capacidade de carga útil dos veículos}

Nesse tópico, o intuito foi o alcance de economias de escala no transporte. Para que o comportamento da capacidade de carga pudesse ser compreendido, dez diferentes veículos, de diferentes tamanhos e distintos custos fixos e variáveis foram simulados. Alguns veículos que não são utilizados no transporte agrícola, principalmente a granel, fizeram parte das análises. Entretanto, o objetivo foi apenas dar ênfase à argumentação. 
pois para que as curvas pudessem ser adequadamente traçadas, havia a necessidade de modelos de baixa capacidade de carga. A gama de capacidade variou de 0,55 à 27 t. Os resultados das simulações realizadas para o cenário C são apresentados pela Tabela 12. Os custos dos veículos simulados foram obtidos em Frota \& Cia (1999).

Tabela 12. Variações do custo unitário de transporte em função da capacidade de carga de dez modelos de veículos

\begin{tabular}{rrrr}
\hline Veículo & Capacidade de carga (t) & Custo unitário $\left(\mathrm{R} \$ . \mathrm{t}^{-1}\right)$ & Valor relativo (\%) \\
\hline 1 & 0,55 & 49,35 & 100,00 \\
2 & 1,00 & 31,55 & 63,93 \\
3 & 3,80 & 8,84 & 17,91 \\
4 & 3,91 & 9,26 & 18,76 \\
5 & 3,98 & 9,58 & 19,41 \\
6 & 7,78 & 5,90 & 11,96 \\
7 & 8,06 & 5,77 & 11,69 \\
8 & 10,59 & 4,94 & 10,01 \\
9 & 18,20 & 4,12 & 8,35 \\
10 & 27,00 & 3,30 & 6,69 \\
\hline
\end{tabular}

Caso a transferência da produção fosse realizada com o veículo 4, um caminhão de 3,9 t de capacidade de carga, o custo de transporte, por tonelada, seria de $\mathrm{R} \$$ 9,26. Ao contrário, se fosse utilizada uma carreta de 27 t (veículo 10), apesar de essa possuir custos fixos e variáveis significativamente superiores ao primeiro modelo, o custo cairia para R\$ 3,30 por tonelada. Essa redução demonstra que existem fortes economias de escala envolvidas e, sob o ponto de vista estrito do transporte, há razões econômicas em utilizar veículos de maior capacidade.

A Figura 41 apresenta os resultados das simulações realizadas com os dez veículos no transporte da produção nos cenários A, B e C. 


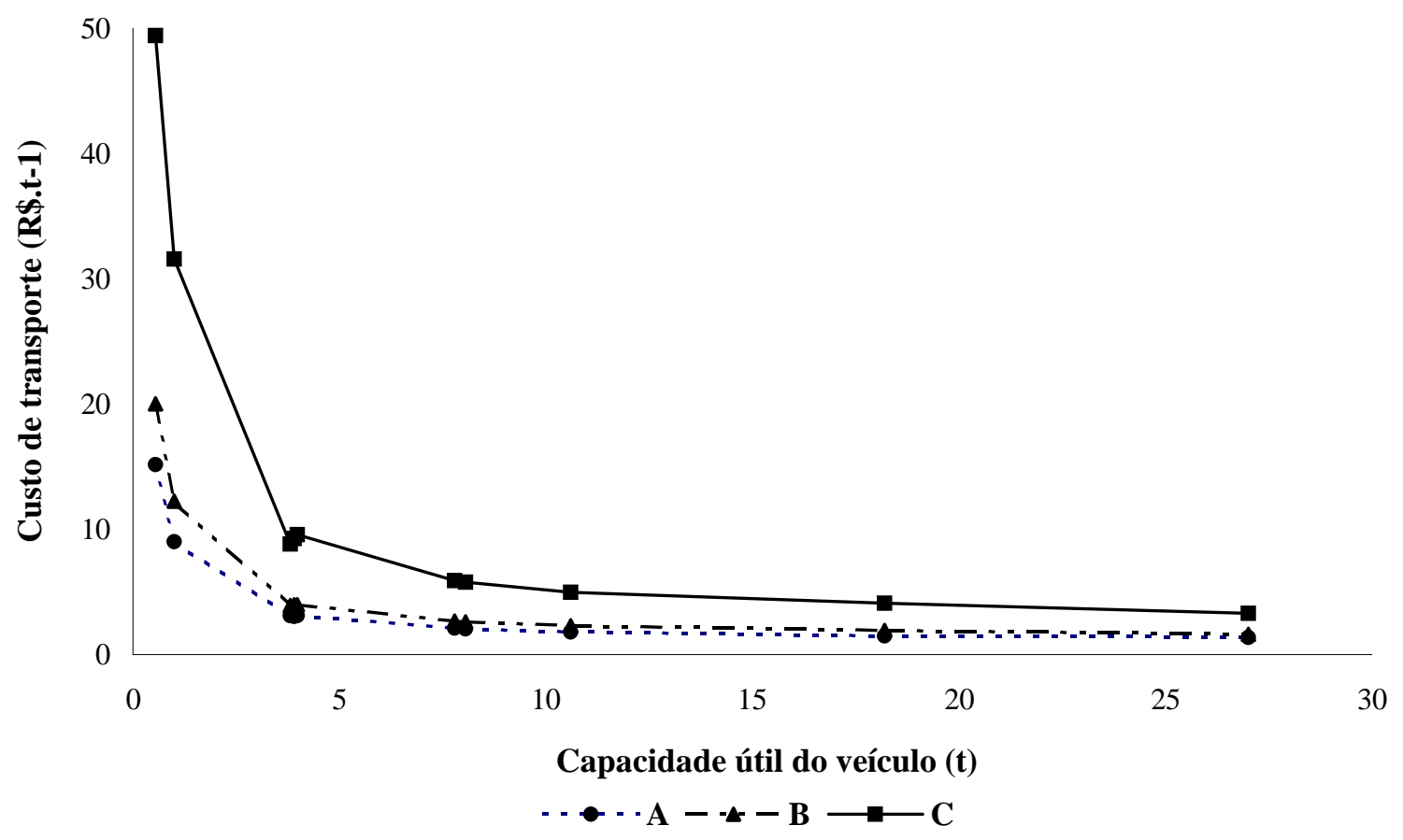

Figura 41 - Variações do custo unitário de transporte em função da capacidade de carga dos veículos, cenários A, B e C

À medida que a capacidade de carga foi reduzida, os custos de transporte assumiram maiores proporções, elevando a sua participação no custo final da tonelada. Em sistemas de rotas mais longas, de maior distância, a economia tornou-se ainda superior. Nesses, (cenário C) os custos sofreram maiores impactos com a utilização de veículos de baixa capacidade do que nos de rotas curtas (cenário A). Os resultados demonstram que, quanto maior for a distância, maior deve ser a busca pela utilização de veículos de maior capacidade, a fim de minimizar os custos de transporte.

As mesmas considerações feitas para os veículos, quanto à suas capacidades de carga, podem ser aplicadas às carretas graneleiras, uma vez que, em suma, sua função também é a transferência de produção. Quanto maior for o distanciamento entre veículos e colhedoras, e quanto maior for a produção a ser transbordada, uma maior atenção deve ser dada na seleção por carretas de maior porte, desde que isso não cause prejuízos como a compactação do solo. Pneus de baixa pressão de insuflagem são uma boa alternativa. 


\subsubsection{Distância de rota}

As taxas de incremento do custo de transporte em função de aumentos percentuais no comprimento das rotas são apresentadas pela Figura 42. Uma vez que, no custeio $A B C$, a individualização dos custos fixos se dá com base em uma grandeza de tempo, em horas, e não mais em uma de distância, em quilômetros, os custos variáveis foram os que sofreram as maiores contribuições com os incrementos de distâncias. Também, os custos variáveis e a distância das rotas se mostraram direta e linearmente proporcionais. Quanto maiores foram as distâncias, maiores foram os custos variáveis envolvidos.

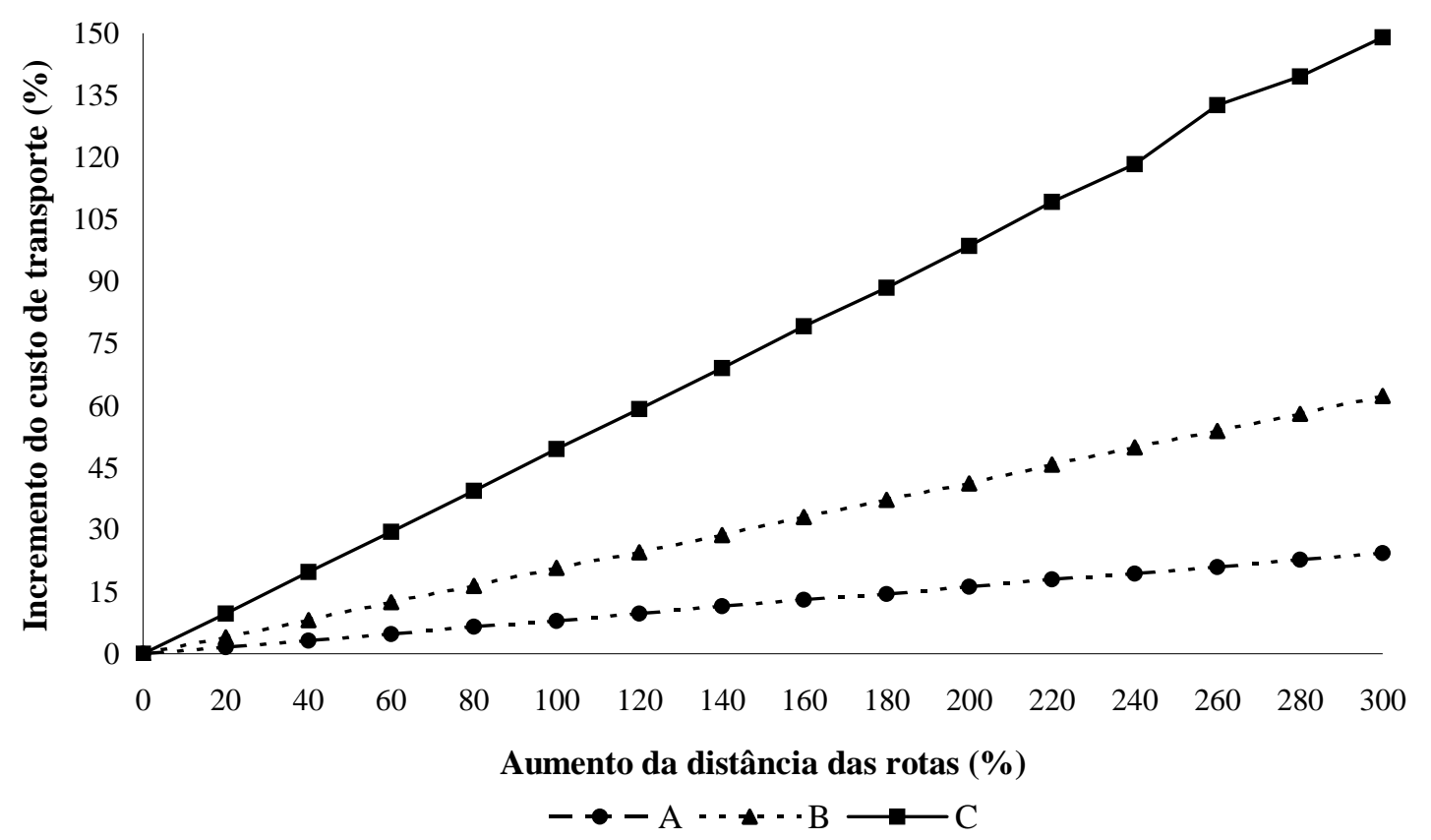

Figura 42 - Incremento do custo de transporte em função de aumentos percentuais no comprimento das rotas, cenários A, B e C

\subsubsection{Horas-ano de utilização dos veículos}

As reduções do custo de transporte em função de incrementos no número de horas-ano de utilização dos veículos são apresentadas pela Figura 43. 
No custeio $A B C$ aplicado à logística de distribuição, os custos fixos são feitos unitários com base no tempo, e não na distância, da forma que o método convencional utilizada. Em função dessa premissa, quanto maior foi a utilização anual dos veículos, menores foram os encargos fixos por hora trabalhada. A Figura 58 mostra que as curvas de custo aumentaram a uma taxa decrescente em relação ao número de horas-ano. Pequenos incrementos desse se refletiram em acentuadas reduções de custo. No cenário A as reduções se mostraram ainda mais acentuadas, por suas rotas serem reduzidas e os veículos permanecerem um tempo maior em atividades de carga e descarga.

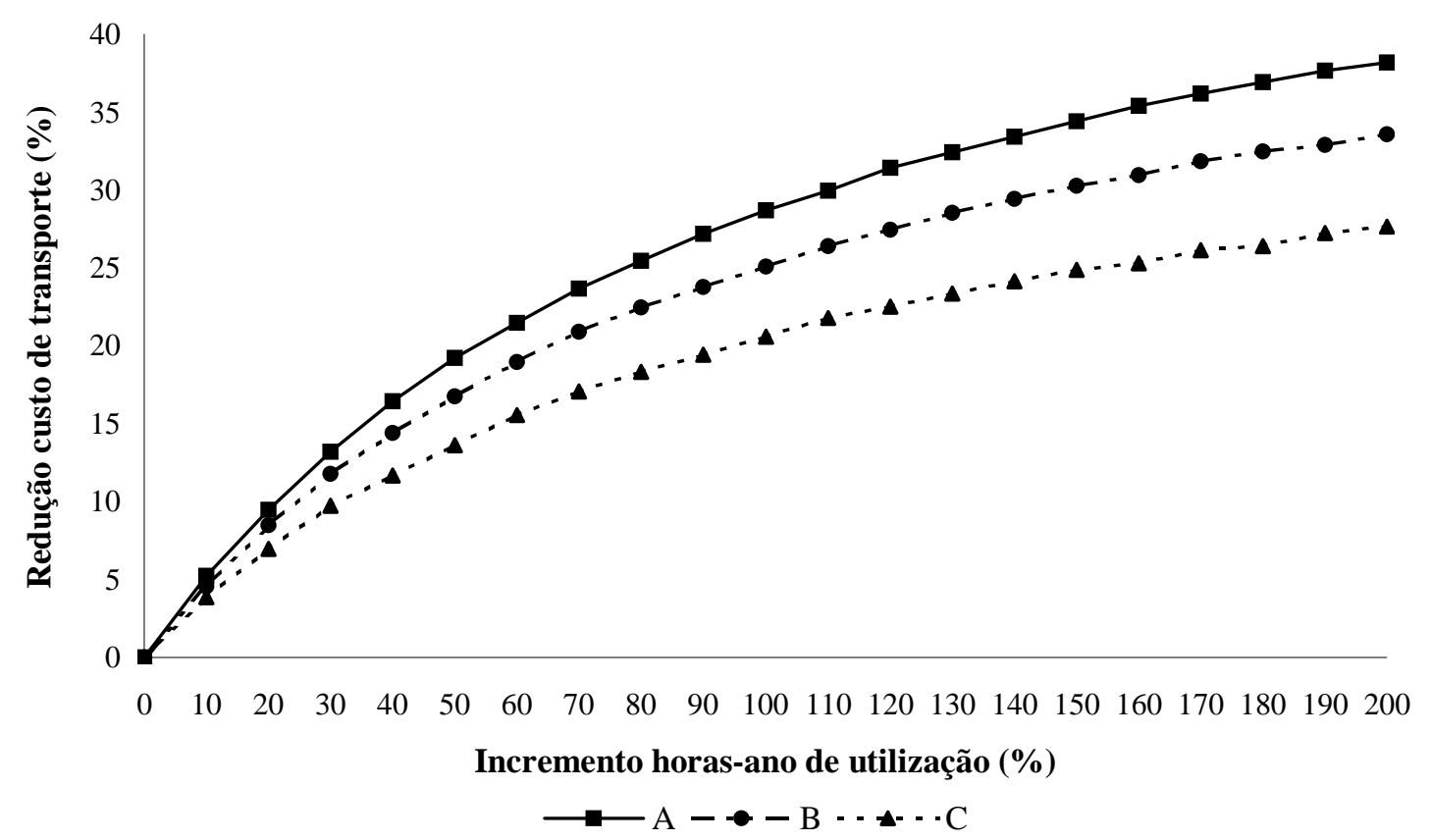

Figura 43 - Reduções do custo de transporte em função de incrementos no número de horas-ano de utilização dos veículos, cenários A, B e C

\subsection{Estratégias de colheita: análise}

As estratégias de colheita analisadas foram focadas no planejamento do prazo de retirada da produção, quanto às limitações de recebimento das unidades de recepção e de limitação de maquinaria, e no comportamento dos sistemas mediante a retirada dos seus componentes intermediários. Os resultados alcançados são apresentador a seguir. 


\subsubsection{Planejamento do prazo de retirada da produção}

As curvas de comportamento dos custos como função do prazo de retirada são mostradas pela Figura 44. Tanto o custo total como o dos subsistemas são enfocados.

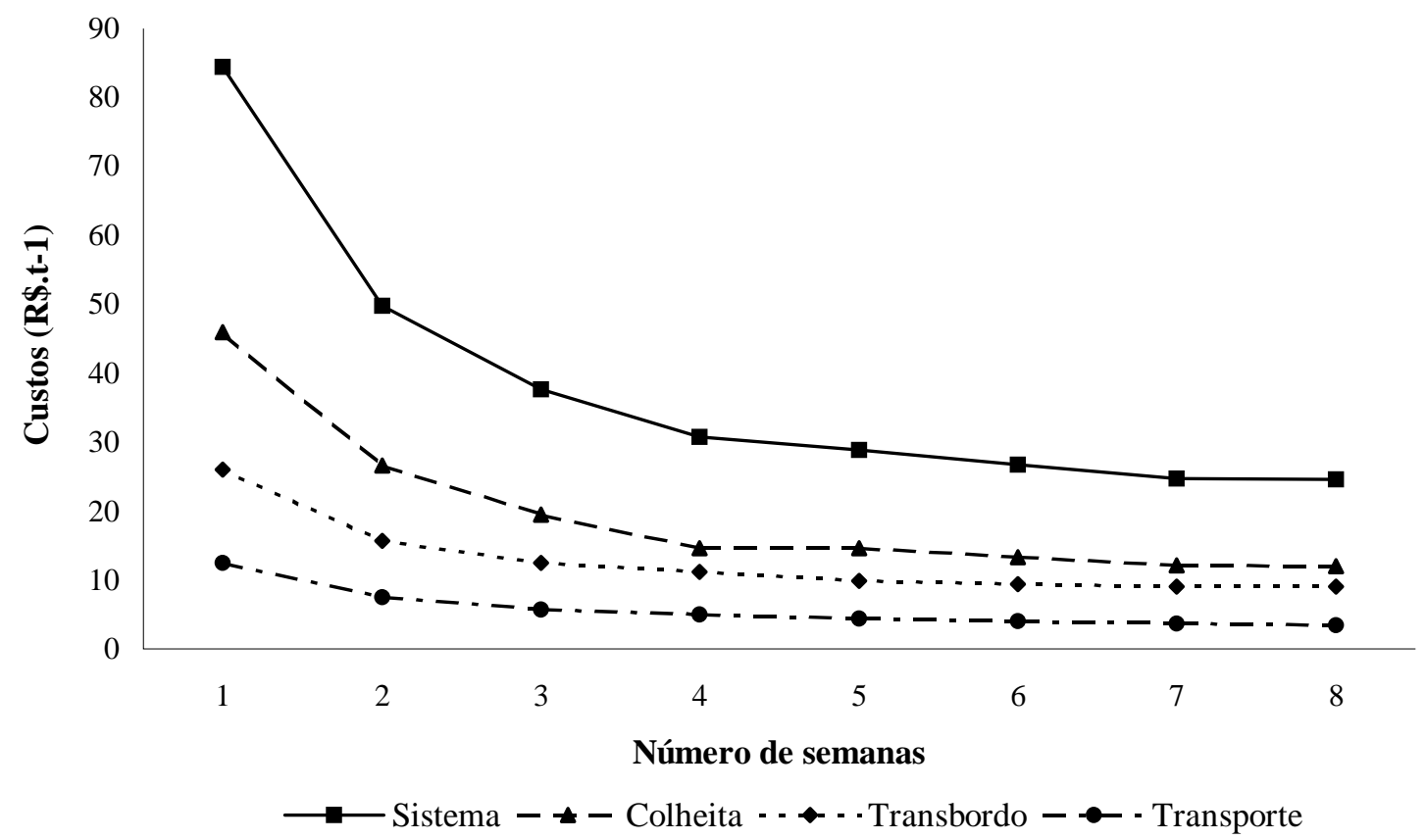

Figura 44 - Comportamento dos custos finais de sistema, de colheita, de transbordo e de transporte mediante incrementos no prazo de retirada de produção

O comportamento das curvas demonstrou haver substanciais reduções de custo com a prorrogação do prazo de totalização da meta a ser alcançada. Realizar a colheita de toda a produção em apenas uma semana acarretou um custo final de R\$ 84 para cada tonelada colhida. Em contrapartida, o custo de uma operação de mesma configuração, alterada apenas no prazo de cumprimento da meta, de 1 para 4 semanas, foi de R\$ 31 por tonelada, uma redução de mais de 60\%. De fato, uma vez as características operacionais e o desempenho de cada máquina, nas simulações, foram mantidas constantes, o número de equipamentos necessários à retirada da meta no prazo elevou-se de modo acentuado.

Antes da apresentação dos resultados quanto aos prazos de retirada, algumas ponderações sobre a capacidade de colheita da frota de colhedoras fazem-se necessárias. 
Considerando a largura nominal de suas plataformas, de 6,8 m (23'), a velocidade de colheita, de $8 \mathrm{~km} \cdot \mathrm{h}^{-1}$, a produtividade média de cultura, de 3,5 t.ha ${ }^{-1}$ e a jornada diária, de 10 h, cada uma das colhedoras apresentou, por dia, uma capacidade potencial máxima de retirada de produção de 190 t. Esse valor, multiplicado pelo número de máquinas, 4, determina a capacidade efetiva de colheita da frota, de 760 t.dia $^{-1}$.

Contudo, conforme anteriormente discutido, a capacidade efetiva é apenas um valor teórico, de referência, que não pode ser alcançado. Isso porque existem tempos que são improdutivos do ponto de vista da retirada de produção, mas que são, ao mesmo tempo, obrigatoriamente exigidos pela operação, por fazerem parte de seu procedimento operacional. Além disso, invariavelmente ocorrem sub-aproveitamentos das plataformas de corte e tempos perdidos por falhas de gerência e/ou de dimensionamento de sistema. Para que a capacidade real da frota possa ser conhecida, a capacidade efetiva precisa ser multiplicada pelo seu fator de aproveitamento. A Tabela 13 apresenta a capacidade de trabalho, em toneladas por dia, a ser demonstrada pela frota em função da eficiência com qual o sistema for operado e do número diário de horas de operação.

Tabela 13. Capacidade de retirada de produção da frota frente à variações na eficiência de campo e no número de horas diário de operação (t.dia ${ }^{-1}$ )

\begin{tabular}{cccccccccc}
\hline $\begin{array}{c}\text { Jornada } \rightarrow \\
\downarrow \text { Eficiência }\end{array}$ & $8 \mathrm{~h}$ & $9 \mathrm{~h}$ & $10 \mathrm{~h}$ & $11 \mathrm{~h}$ & $12 \mathrm{~h}$ & $13 \mathrm{~h}$ & $14 \mathrm{~h}$ & $15 \mathrm{~h}$ & $16 \mathrm{~h}$ \\
\hline $50 \%$ & 305 & 343 & 381 & 419 & 457 & 495 & 533 & 571 & 609 \\
$55 \%$ & 335 & 377 & 419 & 461 & 503 & 545 & 586 & 628 & 670 \\
$60 \%$ & 366 & 411 & 457 & 503 & 548 & 594 & 640 & 685 & 731 \\
$65 \%$ & 396 & 446 & 495 & 545 & 594 & 644 & 693 & 743 & 792 \\
$70 \%$ & 426 & 480 & 533 & 586 & 640 & 693 & 746 & 800 & 853 \\
$75 \%$ & 457 & 514 & 571 & 628 & 685 & 743 & 800 & 857 & 914 \\
$80 \%$ & 487 & 548 & 609 & 670 & 731 & 792 & 853 & 914 & 975 \\
$85 \%$ & 518 & 583 & 647 & 712 & 777 & 842 & 906 & 971 & 1036 \\
\hline
\end{tabular}

Tomando-se como ponto de partida a eficiência de configuração no cenário B, 
de 70\%, bem como o seu número diário de horas de operação, de 10 h, a capacidade real da frota foi de 530 toneladas por dia. Algumas medidas podem ser adotadas para que esse valor seja elevado, e elas são discutidas nos próximos tópicos.

\subsubsection{Cenário 1: limitação por capacidade de recebimento}

Como demonstrou a Tabela 13, para a jornada de 10 h, mesmo que o nível de eficiência da operação fosse de apenas $50 \%$, a capacidade de retirada da frota já seria superior à capacidade de recebimento, de 250 t.dia $^{-1}$. Em situações como essa, a unidade de recepção é o fator limitante de sistema, uma vez que impede a realização da colheita em um menor prazo. Nesse cenário, o prazo mínimo de colheita foi de seis semanas.

No SisColhe, a retirada de produção, ao longo da jornada diária, ocorre a uma taxa constante, o que faz com que uma mesma quantidade de produto seja colhida a cada hora de operação. No cenário atual, a taxa é de $25 \mathrm{t}^{-1}{ }^{-1}$. Quanto ao posicionamento, o raio médio de distância simulado entre os veículos e as colhedoras foi de $500 \mathrm{~m}$. Embora possam existir pontos de maiores distanciamentos, e pontos de menores, esse foi o valor assumido como padrão. Um comparativo entre uma série de parâmetros de desempenho e de custo, mediante a adoção de formas de descarregamento distintas, é mostrado pela Tabela 14. Enquanto que, em (i), os descarregamentos dos graneleiros das colhedoras foram simulados com as máquinas paradas, em (ii) esses foram feitos com as mesmas em movimento.

Mediante o propósito de elaboração do presente cenário, de impor ao sistema uma limitação de capacidade de recebimento, não houve a necessidade de operação de toda a maquinaria, em nenhuma das alternativas verificadas. Para que as demandas de ambas as alternativas fossem satisfeitas, apenas duas máquinas, de um total de quatro, foram suficientes. O número necessário de equipamentos foi obtido, nesse cenário e nos demais, pela razão entre a taxa de retirada requerida pelo sistema e a capacidade individual de cada máquina. Como em (i) e em (ii) cada colhedora demonstrou, respectivamente, uma capacidade de colheita de 11,8 e 13,2 toneladas por hora, apenas duas foram necessárias à retirada das 25 requeridas.

Na comparação entre as alternativas, um melhor ganho de desempenho pôde 
ser obtido com o sistema que descarregou as colhedoras sem a interrupção da colheita. Por menor que tenha sido, a redução de 1,6 minuto na duração de cada ciclo, equivalente ao tempo de esvaziamento do tanque graneleiro, fez com as colhedoras tivessem suas capacidades aproveitadas em um nível 8\% superior. Esse maior aproveitamento, por conseqüência, fez com que suas taxas de retirada se elevassem em 1,5 tonelada por hora de operação, elevando também, inclusive, o desempenho dos transbordos e dos veículos.

Tabela 14. Desempenho e custo da maquinaria em função da forma de descarregamento, 250 t.dia $^{-1}$

\begin{tabular}{|c|c|c|c|}
\hline & Parâmetros & (i) & (iv) \\
\hline \multirow{2}{*}{ 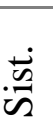 } & Taxa de retirada $\left(\mathrm{t}^{\mathrm{n}} \mathrm{h}^{-1}\right)$ & 25,0 & 25,0 \\
\hline & Descarregamento & Parada & Em Movimento \\
\hline \multirow{4}{*}{$\vec{U}$} & Tempo de ciclo (min) & 15,2 & 13,6 \\
\hline & Eficiência (\%) & 62 & 70 \\
\hline & Capac. de retirada $\left(\mathrm{t} . \mathrm{h}^{-1}\right)$ & 11,8 & 13,2 \\
\hline & Número de colhedoras & 2 & 2 \\
\hline \multirow{2}{*}{$\stackrel{\oplus}{\oplus}$} & Capac. de transbordo (t.h $\left.\mathrm{h}^{-1}\right)$ & 6,4 & 6,9 \\
\hline & Número de conjuntos & 4 & 4 \\
\hline \multirow{2}{*}{ 号 } & Capac. de transporte $\left(\mathrm{t} . \mathrm{h}^{-1}\right)$ & 3,8 & 4,0 \\
\hline & Número de veículos & 7 & 6 \\
\hline \multirow{4}{*}{ 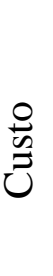 } & Custo de colheita $\left(\mathrm{R} \$ . \mathrm{t}^{-1}\right)$ & 13,3 & 12,1 \\
\hline & Custo de transbordo $\left(\mathrm{R} \$ . \mathrm{t}^{-1}\right)$ & 9,7 & 9,2 \\
\hline & Custo de transporte $\left(\mathrm{R} \$ . \mathrm{t}^{-1}\right)$ & 3,7 & 3,6 \\
\hline & Custo de sistema $\left(\mathrm{R} \$ . \mathrm{t}^{-1}\right)$ & 26,7 & 24,9 \\
\hline
\end{tabular}

A análise de custos demonstrou também haver razões econômicas para realizar o descarregamento em movimento. Todos os subsistemas apresentaram reduções de seus custos por tonelada. Em se tratando do custo final, de sistema, a redução foi de 7\%, o que, em relação à produção considerada, de 7500 t, equivale à R\$ 13.500 . 


\subsubsection{Cenário 2: Limitação por capacidade de maquinaria}

A Tabela 15 apresenta os resultados obtidos com a redução do prazo de 6 para 2 semanas. Devido a redução do número de dias de operação, a taxa de retirada, em quantidade por unidade de tempo, requerida pelo sistema para a totalização da colheita no prazo previsto, se elevou de 25 para 91,3 t.h ${ }^{-1}$. Duas alternativas foram analisadas: em (i), os veículos se encontraram posicionados a 500 m de distância das colhedoras e, em (ii), a 200 m. Em ambas, o descarregamento simulado foi o em movimento.

Tabela 15. Desempenho e custo da maquinaria obtidos com a redução do prazo de 6 para 2 semanas, 750 t.dia ${ }^{-1}$

\begin{tabular}{|c|c|c|c|}
\hline & Parâmetros & (i) & (iv) \\
\hline \multirow{2}{*}{$\stackrel{\ddot{n}}{\dot{n}}$} & Taxa de retirada $\left(\mathrm{t} . \mathrm{h}^{-1}\right)$ & 91,3 & 91,3 \\
\hline & Posicionamento (m) & 500 & 200 \\
\hline \multirow{4}{*}{ 已 } & Tempo de ciclo (min) & 13,6 & 13,6 \\
\hline & Eficiência (\%) & 70 & 70 \\
\hline & Capac. de retirada $\left(\mathrm{t} . \mathrm{h}^{-1}\right)$ & 13,2 & 13,2 \\
\hline & Número de colhedoras & 7 & 7 \\
\hline \multirow{2}{*}{ 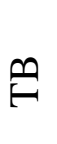 } & Capac. de transbordo (t.h $\left.{ }^{-1}\right)$ & 6,9 & 7,5 \\
\hline & Número de conjuntos & 13 & 12 \\
\hline \multirow{2}{*}{ 号 } & Capac. de transporte $\left(\right.$ t. $\left.^{-1}\right)$ & 4,0 & 4,2 \\
\hline & Número de veículos & 23 & 22 \\
\hline \multirow{4}{*}{$\begin{array}{l}\stackrel{0}{\mathscr{U}} \\
\stackrel{3}{J}\end{array}$} & Custo de colheita $\left(\mathrm{R} \$ . \mathrm{t}^{-1}\right)$ & 21,8 & 21,8 \\
\hline & Custo de transbordo $\left(\mathrm{R} \$ . \mathrm{t}^{-1}\right)$ & 14,5 & 13,4 \\
\hline & Custo de transporte $\left(\mathrm{R} \$ . \mathrm{t}^{-1}\right)$ & 6,7 & 6,4 \\
\hline & Custo de sistema (R\$.t $\left.\mathrm{t}^{-1}\right)$ & 43,0 & 41,6 \\
\hline
\end{tabular}

Considerando a jornada de 10 h, em uma primeira instância, a meta do sistema seria de 75 toneladas por hora, o que, ao final do dia, proporcionaria a retirada das 750 toneladas diárias requeridas. Entretanto, há de se considerar que o período de colheita definido, a última quinzena de março, se caracteriza por uma porcentagem de dias secos 
de apenas $66 \%$ dos dias totais. Assim, uma maior taxa foi programada pela rotina a fim de suplantar essa redução de tempo disponível. O valor calculado foi de $91,3 \mathrm{t} \cdot \mathrm{h}^{-1}$.

Para a alternativa configurada para uma menor distância, o custo de sistema foi inferior. Uma vez que menos tempo foi desprendido pelas carretas nas viagens de ida e de volta das colhedoras aos veículos, as mesmas tiveram as suas capacidades de realizar o transbordo da produção elevadas, reduzindo o número de conjuntos. Simultaneamente, a capacidade de transporte também foi elevada, e o número de caminhões reduzido, em função dos menores tempos de carregamento.

O desempenho das colhedoras nesse cenário foi semelhante ao demonstrado no cenário 1. Isso porque as suas características operacionais, em termos de plataforma e de velocidade, e do sistema, em termos de eficiência, não foram alteradas, o que manteve as suas capacidades operacionais em um mesmo nível. A razão entre a taxa de retirada requerida pelo sistema, de 91,3 t.h ${ }^{-1}$, e a capacidade individual de cada máquina, de 13,2 t.h $\mathrm{h}^{-1}$, resultou no número de máquinas necessário ao sistema, 7 unidades.

Em todos os subsistemas, a redução do tempo disponível refletiu-se em um substancial incremento do número de equipamentos. Como foi justamente o propósito da elaboração do presente cenário, com a referida redução o sistema passou a ser limitado pela capacidade de colheita da maquinaria, e não mais pela capacidade das unidades de recepção. Para que a atual frota de colhedoras, composta por 4 unidades, pudesse ser capaz de cumprir a meta de retirada sem que fosse alterado o nível de aproveitamento de suas capacidades efetivas, a jornada diária necessitaria ser elevada para, ao menos, 15 h.

A fim de reduzir essa limitação, a estratégia avaliada constou da opção por um melhor dimensionamento da maquinaria. Para tanto, elevou-se a capacidade potencial da frota, selecionando-se equipamentos de maior porte. Colhedoras de maior plataforma, carretas graneleiras e veículos de maior capacidade nominal de carga foram simulados. Os resultados alcançados são apresentados na Tabela 16, e a descrição dos equipamentos simulados no Anexo D. Todas as demais configurações foram mantidas constantes.

A estratégia de reformular a frota, a fim de elevar a sua capacidade potencial, mostrou-se válida, tanto ao nível de desempenho quanto ao nível de custos. A utilização de plataformas maiores, de 30’', em contrapartida às anteriores, de 23”', elevou em 33\% 
a capacidade operacional das colhedoras, e fez com que a frota fosse reduzida de 7 para 5 unidades. Em se tratando de custos, pode-se considerar que esses se mostraram dentro de padrões aceitáveis, haja vista o valor de aquisição 48\% superior das novas máquinas.

Tabela 16. Desempenho e custo da maquinaria, 750 t.dia ${ }^{-1}$ - Reformulação da frota

\begin{tabular}{|c|c|c|c|}
\hline & Parâmetros & (i) & (iv) \\
\hline \multirow{2}{*}{$\dot{\vec{n}}$} & Taxa de retirada $\left(\mathrm{t} \mathrm{h}^{-1}\right)$ & 91,3 & 91,3 \\
\hline & Posicionamento (m) & 500 & 200 \\
\hline \multirow{4}{*}{ 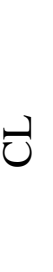 } & Tempo de ciclo (min) & 15 & 15 \\
\hline & Eficiência (\%) & 70 & 70 \\
\hline & Capac. de retirada $\left(\mathrm{t} . \mathrm{h}^{-1}\right)$ & 17,6 & 17,6 \\
\hline & Número de colhedoras & 5 & 5 \\
\hline \multirow{2}{*}{$\stackrel{\varphi}{\oplus}$} & Capac. de transbordo (t.h $\left.{ }^{-1}\right)$ & 10,4 & 11,1 \\
\hline & Número de conjuntos & 9 & 8 \\
\hline \multirow{2}{*}{ 田 } & Capac. de transporte $\left(\mathrm{t}^{\mathrm{h}} \mathrm{h}^{-1}\right)$ & 6 & 6,3 \\
\hline & Número de veículos & 15 & 15 \\
\hline \multirow{4}{*}{ 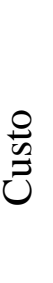 } & Custo de colheita $\left(\mathrm{R} \$ . \mathrm{t}^{-1}\right)$ & 22,6 & 22,6 \\
\hline & Custo de transbordo $\left(\mathrm{R} \$ . \mathrm{t}^{-1}\right)$ & 10,3 & 9,3 \\
\hline & Custo de transporte $\left(\mathrm{R} \$ . \mathrm{t}^{-1}\right)$ & 5,9 & 5,8 \\
\hline & Custo de sistema $\left(\mathrm{R} \$ . \mathrm{t}^{-1}\right)$ & 38,8 & 37,7 \\
\hline
\end{tabular}

Em se tratando dos transbordos, a utilização de carretas de maior capacidade de carga, de 17600 l, proporcionou significativas melhorias em relação ao desempenho demonstrado pelas carretas anteriores, de $9230 \mathrm{l}$. A capacidade do sistema em realizar o transbordo da produção elevou-se em 50\%. Por conseqüência, quatro conjuntos a menos compuseram a frota, independentemente do posicionamento dos veículos. Novamente, o menor distanciamento entre veículos e colhedoras possibilitou um melhor desempenho dos transbordos, reduzindo o número de unidades requerido e os custos envolvidos com a operação. 
A reformulação de frota demonstrou um impacto ainda mais acentuado para o subsistema Transporte. A seleção de carretas de 27 t de carga útil reduziu em 9 unidades o número necessário de veículos. De fato, a capacidade de transporte de produção das carretas mostrou-se 50\% superior à dos caminhões de 17 t.. Os custos de transporte também foram reduzidos significativamente, mesmo considerando-se os maiores valores de aquisição das carretas. Em se tratando dos custos de sistema, as reduções foram da ordem de $12 \%$, uma diferença de mais de $\mathrm{R} \$ 30.000$.

De um modo geral, sempre que grandes produções foram almejadas e/ou a meta for caracterizada por prazo de retirada reduzidos, deve-se optar por máquinas de maior capacidade nominal. Entretanto, alternativas de melhoria de desempenho, ao nível operacional, existem e podem ser aplicadas. Elas são discutidas no próximo item.

\subsubsection{Sistema sem transbordos}

A Tabela 17 apresenta um comparativo realizado entre diversos parâmetros de desempenho e de custo da frota de colhedoras em função da retirada dos transbordos do sistema. Em ambos, o descarregamento foi simulado com as máquinas sem movimento. O posicionamento dos veículos foi mantido constante, a $400 \mathrm{~m}$.

Para que a meta de colheita de 7500 t, a ser retirada em 4 semanas, fosse atingida, o número requerido de colhedoras se elevou de 5 para 6 unidades. De fato, com a retirada dos conjuntos de transbordo, a duração dos ciclos operacionais das unidades de colheita da frota aumentou, uma vez que, fora o tempo de enchimento do graneleiro e de descarregamento, foram incluídos os de deslocamento de ida e de volta aos veículos. Para o posicionamento de $400 \mathrm{~m}$, ao final das 4 semanas, cada colhedora percorreu, em deslocamento, um total de $343 \mathrm{~km}$.

Como a duração dos ciclos foi maior, o número de descarregamentos de cada unidade foi reduzido. Na média, cada colhedora descarregou 20\% menos, porcentagem essa que se refletiu diretamente na redução de suas capacidades de colheita. Como essas foram reduzidas, um maior número de horas-máquina foi necessário ao cumprimento da meta, e uma máquina adicional se fez necessária. Em função desse aumento de frota, o custo de colheita se elevou de R\$17,6 para R\$ 21,5 por tonelada. 
Contudo, apesar dessa unidade adicional, o custo total do sistema reduziu-se substancialmente. De fato, uma vez que, ao todo, deixaram de fazer parte da maquinaria 8 tratores e 8 carretas graneleiras, todos os recursos consumidos por esses, no transbordo da produção, foram retirados. Para o sistema que os utiliza, o custo final da tonelada foi de $\mathrm{R}$ \$34,0. Já para o sistema que não, próximo à R\$ 25,0. Uma diferença da ordem de $26 \%$, ou R\$ 67.000.

Tabela 17. Comparativo entre os sistemas com e sem transbordo

\begin{tabular}{rrr}
\hline Parâmetros de desempenho e custo & \multicolumn{2}{c}{ Sistema de Colheita } \\
& Com Transbordo & Sem Transbordo \\
\hline Produção Colhida (t) & 7476 & 7476 \\
Posicionamento (m) & 400 & 400 \\
Tempo de Ciclo (min) & 15,2 & 19,2 \\
Deslocamento de viagem (km) & 0,0 & 343 \\
Descarregamentos & 542 & 429 \\
Capacidade de Colheita (t.h $\left.{ }^{-1}\right)$ & 11,8 & 9,4 \\
Horas-Máquina (h) & 632 & 800 \\
Número & 5 & 21,5 \\
Custo de colheita (R\$.t ${ }^{-1}$ ) & 17,6 & 25,4 \\
\hline
\end{tabular}

Da forma como a rotina foi escrita, os resultados por ele gerados proporcionam a retirada da produção no prazo estipulado, independentemente das características fornecidas. Essa lógica faz com que, à medida que as capacidades individuais sejam reduzidas, um maior número de máquinas seja requerido ao alcance das metas. É o que demonstraram os resultados apresentados pela Tabela 17. Embora o custo tenha sido inferior, em função da retirada dos componentes intermediários, o número de colhedoras subiu de 5 para 6.

A rotina foi escrita assim porque o SisColhe tem, como um de seus objetivos, servir de auxilio ao planejamento da colheita, a qual inclui o dimensionamento da frota. 
Por isso, ele mostra os resultados necessários para que as necessidades indicadas pelo usuário sejam atendidas. Entretanto, em sistemas reais, a maquinaria normalmente já é formada por um número já determinado de equipamentos e, nem sempre, a aquisição de novas unidades é economicamente viável, principalmente frente a situações de elevados valores de aquisição e de taxas de juros.

Para que o comportamento do sistema sem transbordo frente a variações de posicionamento dos veículos pudesse ser analisado, as duas situações discutidas no item anterior, limitação por capacidade de recebimento e de maquinaria foram novamente simuladas. A Tabela 18 mostra os resultados de desempenho e de custo para o sistema que operou sem carretas graneleiras na taxa de retirada de $250 \mathrm{t} . d i a^{-1}$. O posicionamento foi configurado para 4 diferentes distâncias: (i) 500, (ii) 400, (iii) 300 e (iv) 200 m.

Tabela 18. Desempenho e custo do sistema sem transbordo, 250 t.dia $^{-1}$

\begin{tabular}{|c|c|c|c|c|c|}
\hline & Parâmetros & (i) & (ii) & (iii) & (iv) \\
\hline \multirow{2}{*}{$\stackrel{\ddot{m}}{\dot{m}}$} & Taxa de retirada $\left(\mathrm{t} . \mathrm{h}^{-1}\right)$ & 25,0 & 25,0 & 25,0 & 25,0 \\
\hline & Posicionam. de veículos (m) & 500 & 400 & 300 & 200 \\
\hline \multirow{4}{*}{ U } & Tempo de ciclo (min) & 20,2 & 19,2 & 18,2 & 17,2 \\
\hline & Capacidade de retirada $\left(\mathrm{t} \cdot \mathrm{h}^{-1}\right)$ & 8,9 & 9,4 & 9,9 & 10,4 \\
\hline & Eficiência (\%) & 47 & 49 & 52 & 55 \\
\hline & Número de colhedoras & 3 & 3 & 3 & 2 \\
\hline \multirow{2}{*}{ 色 } & Capacidade de transporte $\left(\mathrm{t} \cdot \mathrm{h}^{-1}\right)$ & 4,7 & 4,9 & 5,0 & 5,2 \\
\hline & Número de veículos & 5 & 5 & 5 & 5 \\
\hline \multirow{3}{*}{ 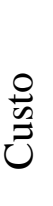 } & Custo de colheita $\left(\mathrm{R} \$ . \mathrm{t}^{-1}\right)$ & 17,9 & 17,2 & 16,5 & 14,5 \\
\hline & Custo de transporte $\left(\mathrm{R} \$ . \mathrm{t}^{-1}\right)$ & 3,0 & 3,0 & 2,9 & 2,9 \\
\hline & Custo de sistema (R\$.t $\left.{ }^{-1}\right)$ & 20,9 & 20,2 & 19,4 & 17,4 \\
\hline
\end{tabular}

Em sistemas que não utilizam transbordos, os resultados sugeriram que uma atenção especial deve ser dada ao posicionamento dos veículos. Nesses sistemas, a taxa de incremento de custo frente a alterações na distância foi mais acentuada, em virtude dos maiores valores de aquisição das colhedoras. O acréscimo de uma máquina adicional 
eleva sobremaneira o custo final da tonelada colhida. Além disso, o nível de eficiência operacional das máquinas reduziu-se com a retirada dos componentes intermediários. Uma vez que as colhedoras passaram a se deslocar ao ponto de parada dos veículos a cada totalização do tanque graneleiro, o tempo de duração entre dois descarregamentos consecutivos, ou de ciclo, foi elevado, o que fez com que as suas capacidade de colheita fossem reduzidas. Também, os descarregamentos ocorreram com as máquinas paradas, contrastando com o movimento característico do sistema que utiliza transbordos.

Contudo, mesmo com a eficiência sendo reduzida para níveis inferiores a 50\%, para o posicionamento de $500 \mathrm{~m}$, apenas 3 unidades, da frota de 4, foram suficientes ao alcance da meta. À medida que os veículos foram posicionados a menores distâncias, o nível de eficiência e, por conseqüência, de capacidade de colheita, foi incrementado. Quanto menos tempo as máquinas permaneceram fora da atividade de colheita, maior foi o seu aproveitamento. A simples alteração em 200 m do posicionamento dos veículos, de 500 para 300 m, fez com que 5\% a mais de aproveitamento fosse obtido.

Nesse ponto, uma ressalva se faz necessária. Mesmo com o posicionamento colhedoras-veículos configurado para, como exemplo, $500 \mathrm{~m}$, nem todo enchimento do tanque graneleiro ocorre a essa distância. Esse é apenas um valor médio, de referência. O enchimento pode ocorrer tanto a distâncias maiores quanto menores. Idealmente, o caminhamento da colheita deve ser tal que a colhedora inicie o seu percurso em uma direção perpendicular ao carreador e, no momento em que alcançar a metade de sua capacidade de armazenagem, retorne sob a mesma direção, colhendo em sentido oposto. Assim, os enchimentos do graneleiros ocorrem próximo ao ponto no qual os veículos se encontram posicionados, evitando deslocamentos excessivos.

De acordo com Hunt (1977), um ótimo caminhamento de colheita segue os padrões do plantio que utiliza faixas de cabeceira. Se a área do talhão e a produtividade da cultura estiverem sincronizadas, a colhedora perfaz um número inteiro de tiros por descarregamento, e sempre descarrega uma carga completa nas faixas de cabeceira, próximas aos carreadores. Entretanto, tais condições ideais são raras.

Os custos finais sem transbordo se mostraram substancialmente inferiores ao do que os utilizou. Todos os custos inerentes aos tratores e as carretas graneleiras foram 
retirados. Também os custos de transporte se reduziram. Isso porque, nesse sistema, o tempo de carregamento dos veículos foi determinado pela capacidade operacional das colhedoras, e não pela dos transbordos. Como, mesmo se deslocando, a capacidade das primeiras foi maior do que a dos segundos, o tempo de carga dos veículos se reduziu, o que fez com que esses demonstrassem uma maior capacidade de transporte de produção e, por conseqüência, tivessem os seus custos reduzidos. Mediante essa maior capacidade, o número de veículos na frota foi reduzido de 7 para 5 unidades. Em termos totais, o custo do sistema sem transbordo se mostrou 22\% inferior ao do sistema que os utiliza, mesmo à distância de 500 m, bem como foi tão menor quanto foram os distanciamentos. Para o de 200 m, esse foi de foi de $\mathrm{R} \$ 17,4$.

Os resultados de desempenho e de custo do sistema operando à taxa de retirada de 750 toneladas por dia são mostrados pela Tabela 19. Os mesmos posicionamentos foram utilizados nas simulações.

Tabela 19. Desempenho e custo do sistema sem transbordo, 750 t.dia $^{-1}$

\begin{tabular}{|c|c|c|c|c|c|}
\hline & Parâmetros & (i) & (ii) & (iii) & (iv) \\
\hline \multirow{2}{*}{$\dot{\vec{\omega}}$} & Taxa de retirada $\left(\mathrm{t} \mathrm{h}^{-1}\right)$ & 91,3 & 91,3 & 91,3 & 91,3 \\
\hline & Posicionam. de veículos (m) & 500 & 400 & 300 & 200 \\
\hline \multirow{4}{*}{ 已 } & Tempo de ciclo (min) & 20,2 & 19,2 & 18,2 & 17,2 \\
\hline & Capacidade de retirada $\left(\mathrm{t} . \mathrm{h}^{-1}\right)$ & 8,9 & 9,4 & 9,9 & 10,4 \\
\hline & Eficiência (\%) & 47 & 49 & 52 & 55 \\
\hline & Número de colhedoras & 10 & 10 & 9 & 9 \\
\hline \multirow{2}{*}{ 咞 } & Capacidade de transporte $\left(\mathrm{t} \cdot \mathrm{h}^{-1}\right)$ & 4,7 & 4,9 & 5,0 & 5,2 \\
\hline & Número de veículos & 20 & 19 & 18 & 18 \\
\hline \multirow{3}{*}{ 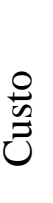 } & Custo de colheita $\left(\mathrm{R} \$ . \mathrm{t}^{-1}\right)$ & 31,5 & 31,0 & 28,3 & 28,0 \\
\hline & Custo de transporte $\left(\mathrm{R} \$ . \mathrm{t}^{-1}\right)$ & 5,9 & 5,7 & 5,4 & 5,4 \\
\hline & Custo de sistema $\left(\mathrm{R} \$ . \mathrm{t}^{-1}\right)$ & 37,4 & 36,7 & 33,7 & 33,4 \\
\hline
\end{tabular}

Em nenhum distanciamento, a frota de 4 colhedoras foi suficiente no alcance da meta prevista. As razões para tanto foram o aumento da taxa de retirada do sistema e 
as reduções das capacidades operacionais das máquinas.

Mediante as maiores taxas de retirada, um nível maior de eficiência também se fez necessário para que a mesma frota fosse capaz de realizar a colheita da produção. É o que demonstram os resultados para o posicionamento de $200 \mathrm{~m}$. Nesse, foi possível um melhor aproveitamento da capacidade potencial das colhedoras, em função da redução dos seus tempos de deslocamento e, por conseqüência, dos seus tempos de ciclo. Devido a esse comportamento, um menor número de máquinas foi requerido. Os custos finais também foram reduzidos, tanto em comparação com a primeira alternativa $(500 \mathrm{~m})$ quanto com o sistema com transbordo. Em relação a esse último, a diferença foi de $20 \%$.

Em sistemas que operam sem transbordo, quanto maior for o distanciamento aos veículos, menores são as suas capacidade de colheita. Esse princípio se equivale ao apresentado pelos transbordos, em sistemas que os utilizam. Entretanto, especialmente para as colhedoras, alternativas de melhor aproveitamento de capacidade efetiva devem ser implementadas para que a produção exigida pela meta possa ser mantida.

Visando buscar formas de melhor aproveitamento da capacidade efetiva da frota, quatro alternativas foram analisadas. A estratégia adotada foi contra balancear a redução do nível de eficiência, decorrente de posicionamentos longínquos, com medidas que permitissem maiores incrementos de capacidade. Para tanto, à medida que maiores distâncias foram simuladas, o nível de incremento de capacidade efetiva, em termos de maior utilização da plataforma, de maior velocidade de colheita e de maior velocidade de deslocamento foi elevado. As alternativas verificadas são mostradas a seguir, e os resultados na Tabela 20. Nelas, as porcentagens referem-se a fatores de acréscimo aos valores originais: (i) $500 \mathrm{~m}$ : 8\% plataforma, 10\% velocidade colheita e 20\% velocidade de deslocamento; (ii) $400 \mathrm{~m}$ : 5\% plataforma, 5\% velocidade colheita e 15\% velocidade de deslocamento; (iii) 300 m: 15\% a mais na velocidade de deslocamento e (iv) 200 m: 10\% a mais na velocidade de deslocamento.

Com a adoção das alternativas descritas, a capacidade de colheita de cada colhedora foi elevada, independentemente do posicionamento dos veículos. Incrementos nas variáveis largura efetiva de plataforma e velocidade de colheita atuam diretamente na capacidade potencial das máquinas. Buscou-se reduzir, de modo especial, os tempos 
nos quais essas permaneceram em deslocamento. Para tanto, só existem dois caminhos: ou diminui-se a distância a ser percorrida ou eleva-se a velocidade de percurso. Buscouse elevar progressivamente essa última a medida que maiores distanciamentos foram avaliados.

Tabela 20. Alternativas sistema colhedoras-veículos

\begin{tabular}{|c|c|c|c|c|c|}
\hline & Parâmetros & (i) & (ii) & (iii) & (iv) \\
\hline \multirow{4}{*}{ 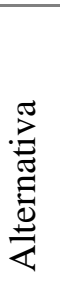 } & Posicionam. de veículos (m) & 500 & 400 & 300 & 200 \\
\hline & Plataforma (\%) & 93 & 90 & 85 & 85 \\
\hline & Veloc. Colheita $\left(\mathrm{km} . \mathrm{h}^{-1}\right)$ & 8,8 & 8,4 & 8,0 & 8,0 \\
\hline & Veloc. Desloca. $\left(\mathrm{km} \cdot \mathrm{h}^{-1}\right)$ & 14,2 & 13,8 & 13,8 & 13,2 \\
\hline \multirow{3}{*}{$\mathcal{U}$} & Capacidade de retirada $\left(\mathrm{t} \cdot \mathrm{h}^{-1}\right)$ & 10,8 & 10,5 & 10,1 & 10,6 \\
\hline & Eficiência (\%) & 57 & 55 & 53 & 56 \\
\hline & Número de colhedoras & 9 & 9 & 9 & 9 \\
\hline \multirow{2}{*}{ 苗 } & Capacidade de transporte $\left(\mathrm{t} \cdot \mathrm{h}^{-1}\right)$ & 5,3 & 5,2 & 5,1 & 5,2 \\
\hline & Número de veículos & 17 & 18 & 18 & 18 \\
\hline \multirow{3}{*}{ 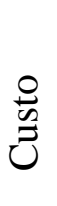 } & Custo de colheita $\left(\mathrm{R} \$ . \mathrm{t}^{-1}\right)$ & 27,8 & 27,8 & 28,2 & 27,9 \\
\hline & Custo de transporte $\left(\mathrm{R} \$ . \mathrm{t}^{-1}\right)$ & 5,2 & 5,4 & 5,4 & 5,4 \\
\hline & Custo de sistema (R\$.t $\left.\mathrm{t}^{-1}\right)$ & 33,0 & 33,6 & 33,6 & 33,3 \\
\hline
\end{tabular}

Mediante a aplicação das alternativas, o custo final de colheita e transporte da tonelada, no sistema sem transbordos, para o posicionamento de $500 \mathrm{~m}$, foi $23 \%$ inferior ao custo do sistema que os utiliza, apresentado pela Tabela 15. Essa diferença, de R\$ 75.000, equivale, no mercado, ao valor de quatro carretas de transbordo de médio porte.

Nenhuma alteração foi feita quanto ao número diário de horas de operação e quanto aos intervalos destinados aos operadores. Somente pequenos incrementos nos parâmetros de desempenho foram suficientes ao aumento da taxa de colheita da frota. Entretanto, com a redução em 50\% do prazo de retirada previsto, de 4 para 2 semanas, apenas os incrementos de capacidade efetiva não foram suficientes para que apenas as 4 máquinas que compõem a frota fossem suficientes ao cumprimento da meta. 
Em função da acentuada redução do número de dias, foram também avaliadas medidas quanto ao número diário de horas de operação. Visou-se compensar parte da redução do tempo disponível, em termos de dias, com incrementos de jornada, tomandose o cuidado de evitar um desgaste excessivo aos operadores. Assim, elevou-se o tempo de gerência diário, destinado às suas refeições, na mesma proporção.

Duas alternativas foram verificadas (Tabela 21). Ambas foram caracterizadas pelo aumento em $8 \%$ na utilização da plataforma, $10 \%$ na velocidade de colheita e 20\% na velocidade de deslocamento, medidas essas semelhantes à adotada para as simulações apresentadas pela Tabela 20. Entretanto, quanto maior foi o posicionamento simulado, maior foi o aumento do número diário de horas de operação requerido. Para a distância de 200 m, 14 h e, para a de 500 m, 16 h de operação diária foram necessárias.

Tabela 21. Alternativa verificada: alteração da jornada diária - sem transbordo

\begin{tabular}{|c|c|c|c|}
\hline & Parâmetros & (i) & (ii) \\
\hline \multirow{3}{*}{$\stackrel{\varpi}{\infty}$} & Posicionam. de veículos (m) & 500 & 200 \\
\hline & Taxa de retirada $\left(\mathrm{t} . \mathrm{h}^{-1}\right)$ & 57,1 & 65,2 \\
\hline & Jornada diária (h) & 16 & 14 \\
\hline \multirow{2}{*}{$\vec{U}$} & Capacidade de retirada $\left(\mathrm{t} . \mathrm{h}^{-1}\right)$ & 10,8 & 12,6 \\
\hline & Número de colhedoras & 5 & 5 \\
\hline \multirow{2}{*}{ 咞 } & Capacidade de transporte $\left(\mathrm{t}^{-h^{-1}}\right)$ & 5,3 & 5,8 \\
\hline & Número de veículos & 11 & 11 \\
\hline \multirow{3}{*}{$\begin{array}{l}\frac{0}{\mathscr{U}} \\
\stackrel{3}{3}\end{array}$} & Custo de colheita $\left(\mathrm{R} \$ . \mathrm{t}^{-1}\right)$ & 18,1 & 17,3 \\
\hline & Custo de transporte $\left(\mathrm{R} \$ . \mathrm{t}^{-1}\right)$ & 4,0 & 3,9 \\
\hline & Custo de sistema (R\$.t $\left.{ }^{-1}\right)$ & 22,1 & 21,2 \\
\hline
\end{tabular}

O número de equipamentos e os custos finais reduziram-se substancialmente com o aumento da jornada. Entretanto, a taxa de retirada exigida pelo sistema ainda foi superior a capacidade da frota, o que exigiu uma máquina adicional. Cinco foi o número de colhedoras requerido. Para que a capacidade da frota possa ser suficiente, a taxa de retirada requerida pelo sistema precisa ser distribuída em um maior número de horas por 
dia, e esse é justamente o efeito que o aumento de jornada de trabalho proporciona. Isso porque a taxa de retirada requerida pelo sistema responde de maneira inversamente proporcional ao número de horas diário. Como uma menor tonelagem é exigida por hora, o número de equipamentos é também reduzido. Uma outra opção interessante é a aquisição de colhedoras de maior porte, de maior plataforma, como as simuladas no item anterior. Caso seja vislumbrada a colheita de safras futuras, em um planejamento a longo prazo, essa alternativa deve ser especialmente levada em consideração.

O efeito de alterações na jornada diária no número requerido de equipamentos é apresentado pela Figura 45. O posicionamento de $500 \mathrm{~m}$, em conjunto com as medidas de incremento de capacidade foi mantido constante.

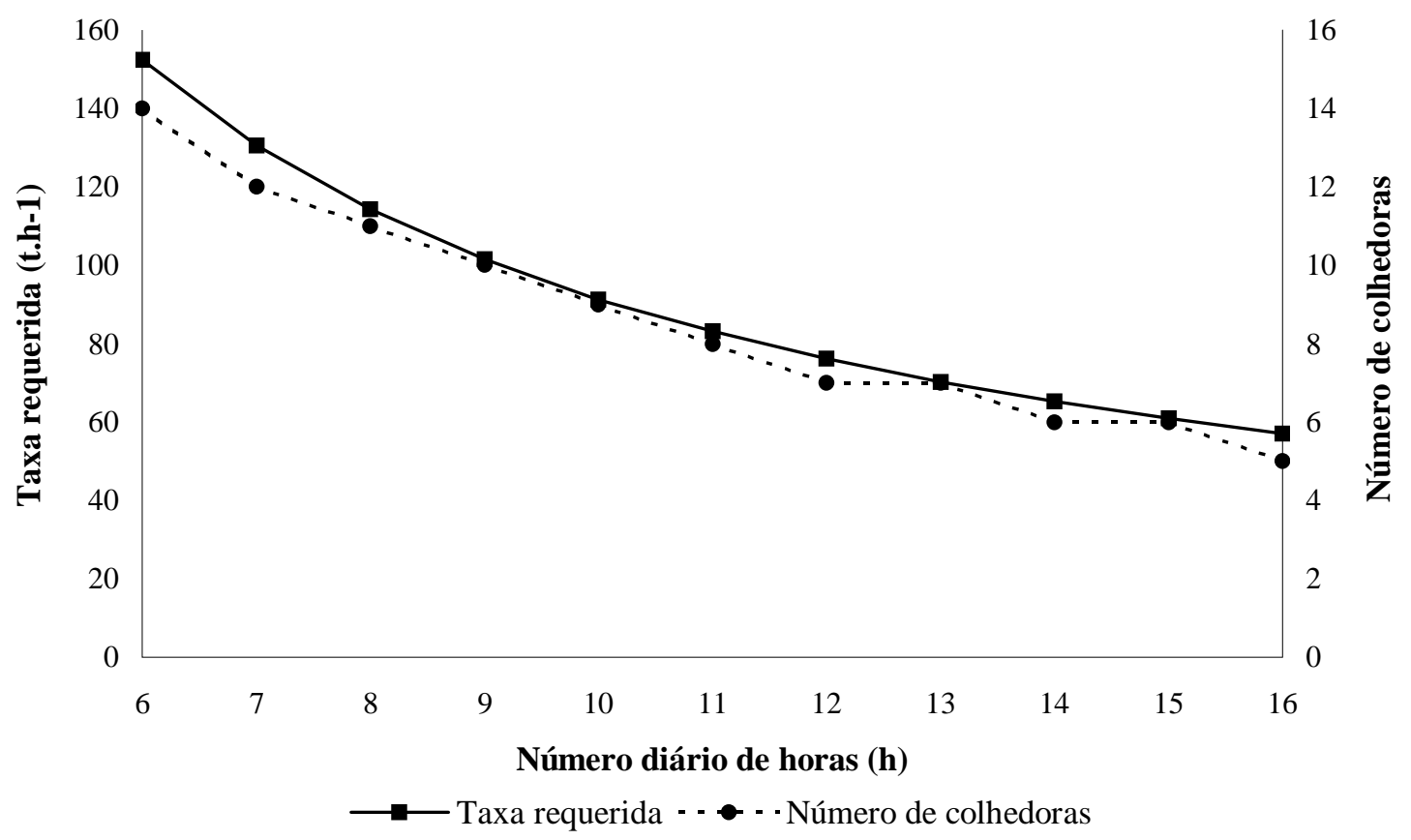

Figura 45 - Dimensionamento da maquinaria frente a alterações na jornada diária de operação

O número diário de horas de operação demonstrou exercer uma forte influencia no dimensionamento da maquinaria, embora não sob uma tendência linear. Para as jornadas curtas, pequenas alterações geraram reduções substanciais no número de equipamentos. 
Entretanto, à medida que a jornada de trabalho foi elevada, essas, embora continuassem a existir, ocorreram a menores taxas. Para a de 12 h, 7 colhedoras seriam suficientes. Já para a de 10 h, 9. Nas simulações, todos os custos foram elevados com as reduções de jornada. Principalmente as colhedoras, em função de seus maiores valores de aquisição. O principio é o mesmo demonstrado para o número de semanas: maior tempo disponível à realização das atividades, menos equipamentos necessários à totalização da meta no prazo. Sob esse enfoque, uma estratégia gerencial passível de ser aplicada é a adoção de turnos múltiplos de operação e/ou de substituição dos operadores, em seus horários de refeição, por outros funcionários, de modo a não interromper a operação.

\subsection{Comparativo entre sistemas}

Em sistemas de colheita que não utilizam transbordos, a taxa de incremento de custo frente à alterações de distância foi mais acentuada do que nos sistemas que os utilizam. Isso porque os valores de aquisição das colhedoras são destacadamente superiores aos dos tratores e das carretas graneleiras. É o que demonstram as curvas de comportamento apresentadas pela Figura 46. As simulações mostraram que pequenos acréscimos de distância acarreta, geram significativos aumentos de custo, caso medidas de incremento de capacidade não sejam adotadas. Uma vez que a distância é maior, as máquinas passam mais tempo em deslocamento, e menos tempo efetivamente retirando a produção, o que faz com que a capacidade de colheita e de transporte do sistema seja reduzida, e com que o número de unidades necessárias ao alcance da meta seja elevado (Figura 47). 


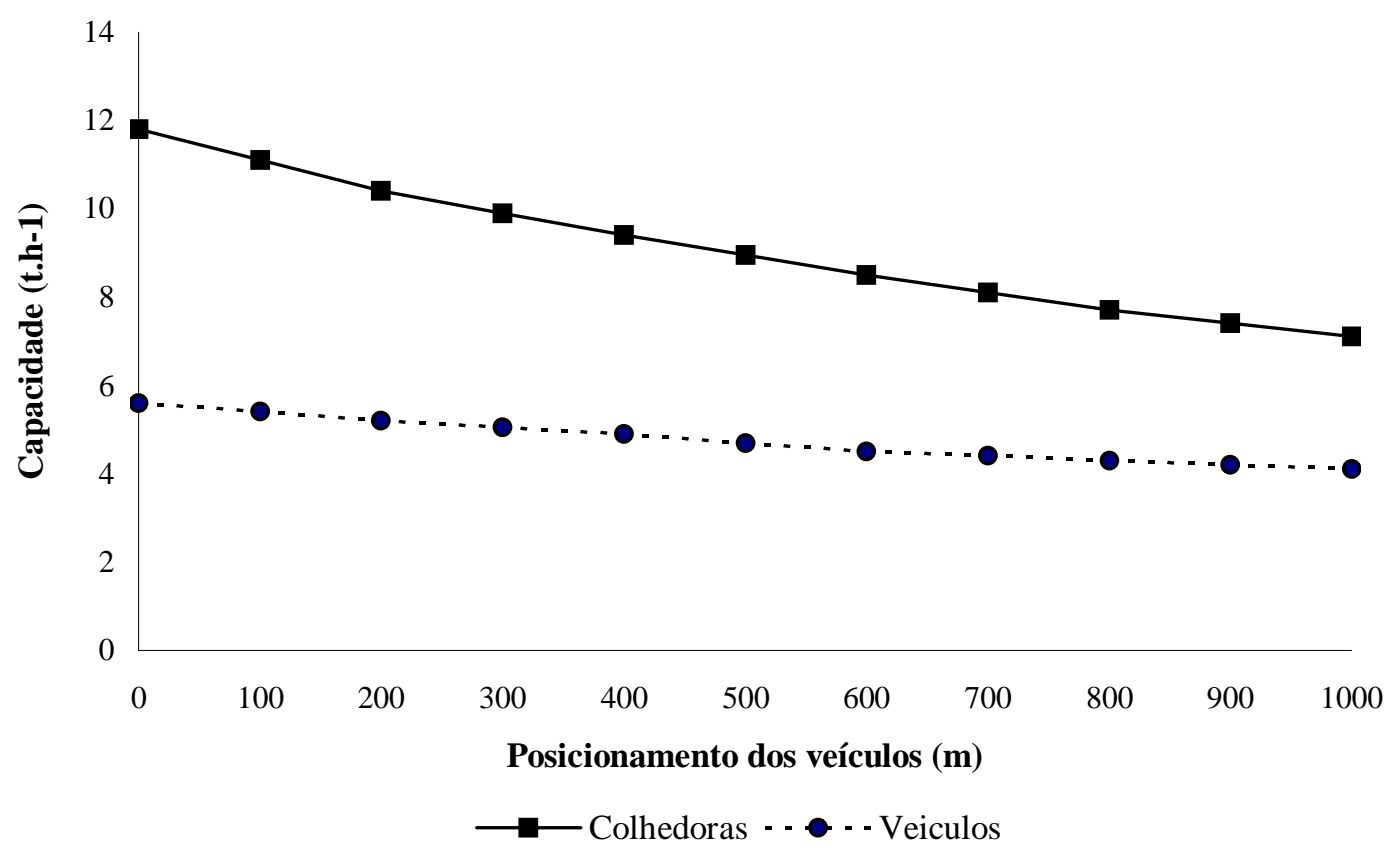

Figura 46 - Taxa de incremento dos custos frente a alterações no posicionamento dos veículos - sistema sem transbordo e sem incremento de desempenho

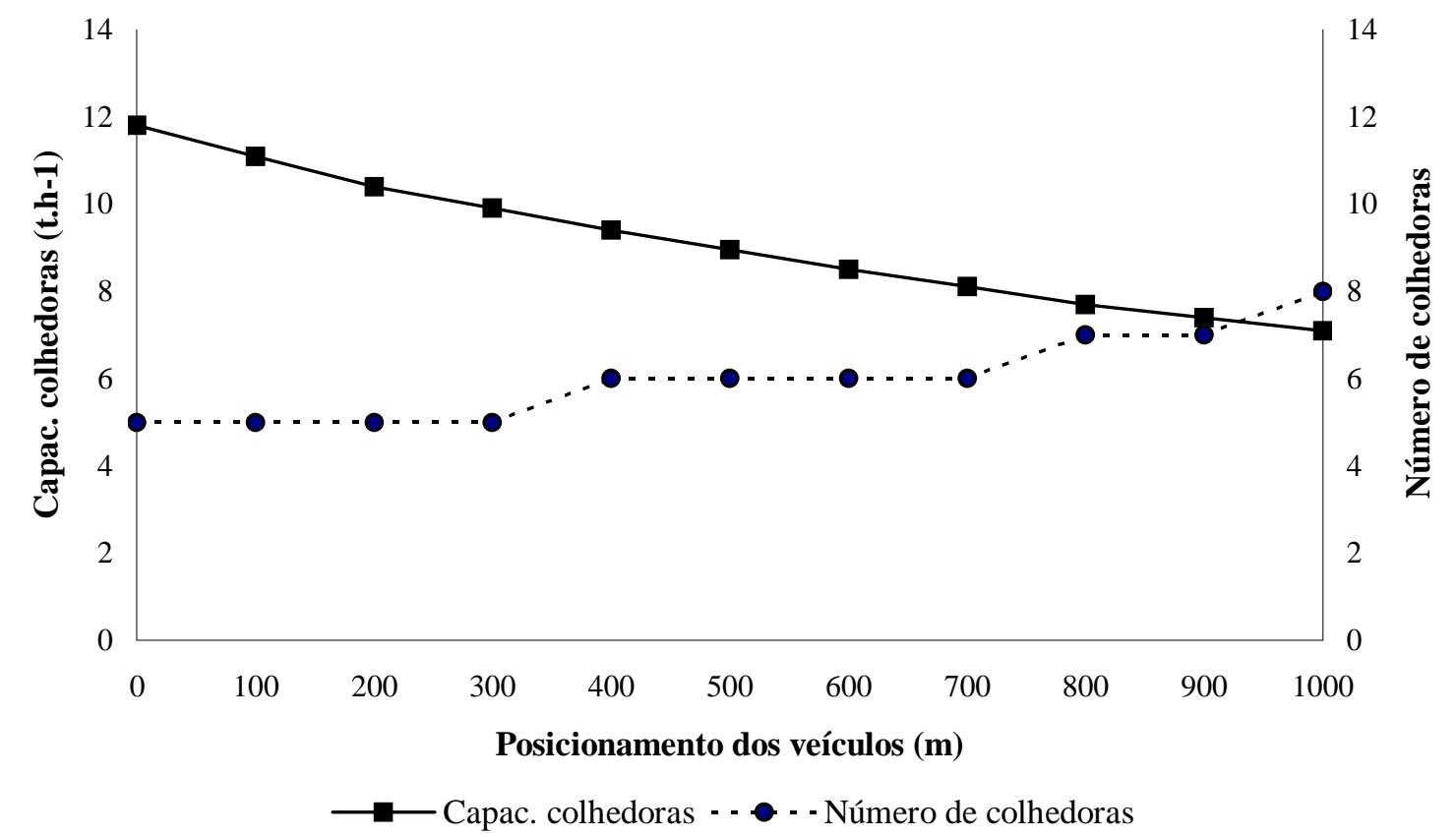

Figura 47 - Redução da capacidade de colheita frente à alterações no posicionamento dos veículos - sistema sem transbordo e sem incremento de desempenho 
Contudo, mesmo com o maior dimensionamento da frota, os resultados das simulações demonstraram que, até uma certa distância, os custos finais do sistema sem transbordo são inferiores aos dos sistemas que os utilizam, como mostra a Figura 48. Na referida figura, um comparativo é feito entre os custos finais do sistema com transbordo e descarregamento em movimento, com transbordo e descarregamento sem movimento e sem transbordo.

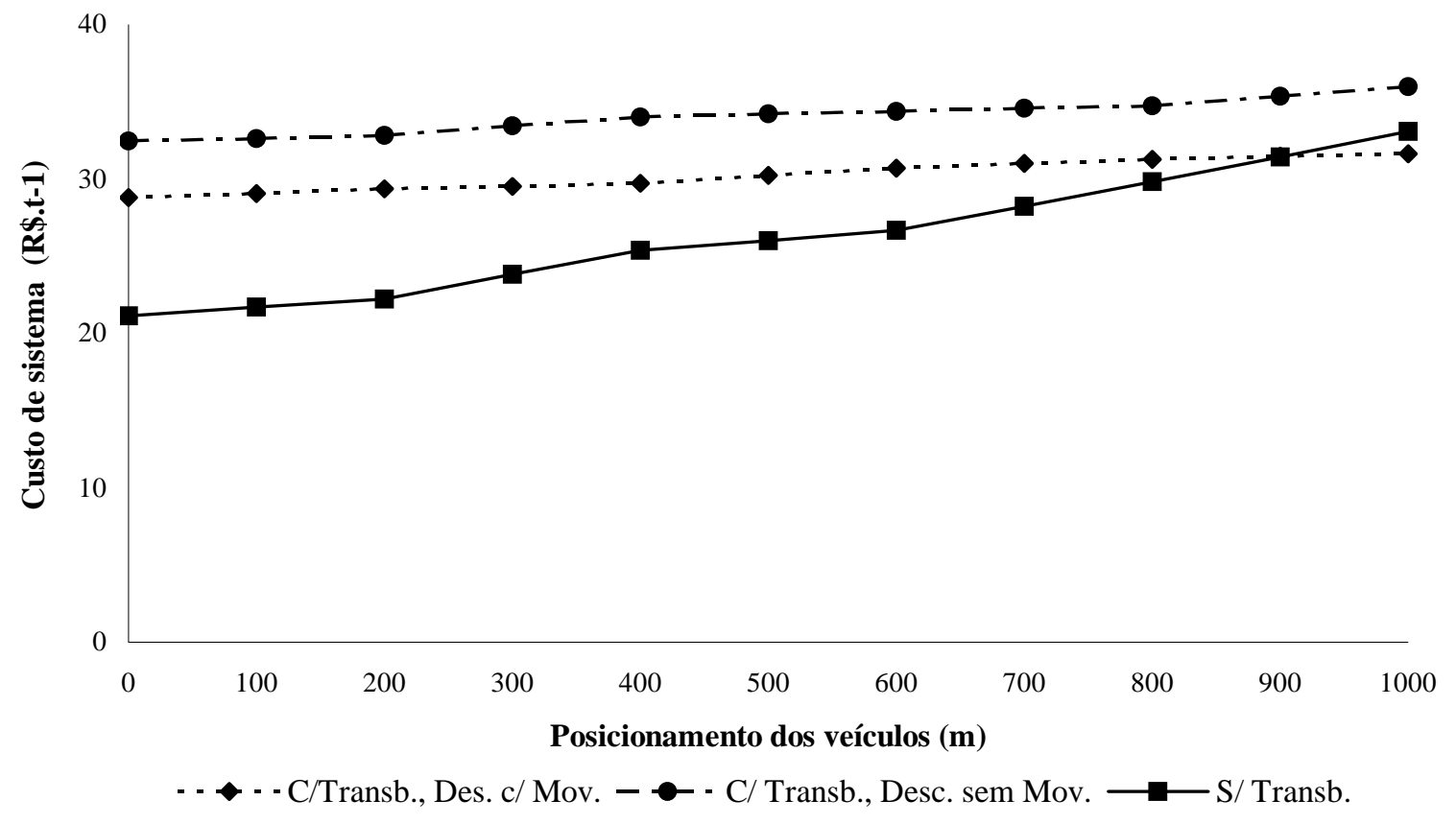

Figura 48 - Custos finais dos três sistemas de colheita avaliados para distintas distâncias colhedoras-veículos

O sistema de menor custo no cumprimento da meta foi aquele no qual não são utilizadas carretas graneleiras e os veículos se posicionam ao lado, à uma distância zero das colhedoras. Esse, sob o ponto de vista de custo e desempenho é um sistema ideal, uma vez que o componente intermediário do sistema, que consume recursos, foi retirado e, mesmo assim, as colhedoras não precisaram se deslocar a cada descarregamento.

Entretanto, todo o impacto ambiental, que se inicia com a compactação do solo pelos pneus dos veículos, e se estende com a redução de sua capacidade de infiltração, 
com o aumento da erosão superficial nos talhões e com a perda futura de produtividade das culturas, impede a sua recomendação. Para a distância de 400 m, o custo do sistema sem transbordo foi de $\mathrm{R} \$ 25,4$ por tonelada colhida enquanto que, o do sistema que o utiliza, de $\mathrm{R} \$ 34,0$.

A alternativa que se mostrou mais econômica foi o posicionamento dos veículos o mais próximo das colhedoras possível, desde que fora da área produtiva dos talhões. Outra medida alternativa interessante é o aumento da área de contato dos pneus dos veículos com o solo, por meio da utilização de pneus de bandas de rodagem mais largas, e/ou de menor pressão.

Apesar do número de colhedoras ter aumentado, até uma distância aproximada de $800 \mathrm{~m}$ o sistema sem transbordo demonstrou custo inferior aos demais. É importante destacar que esse valor, de $800 \mathrm{~m}$, trata-se de um valor específico, e vale apenas para as características e configurações das simulações efetuadas. Ele não é uma regra. Para os cenários A e C, inclusive, a distância na qual as curvas de custo se interceptaram foram outras. Contudo, em todos, os resultados demonstraram que a redução dos custos finais passa pelo projeto e pela estruturação de malhas de trafego e estradas de forma tal que o menor distanciamento entre colhedoras e veículos possa ser obtido. Indubitavelmente, quanto mais acesso os veículos tiverem aos perímetros dos talhões, mais próximos esses poderão se situar das colhedoras, e maior o ganho de desempenho a ser obtido. 


\section{CONCLUSÕES}

- O "SisColhe” está apto a auxiliar a avaliação e a análise de sistemas mecanizados de colheita de cereais, ao nível operacional e econômico. A lógica de comportamento da maquinaria e de suas inter-relações pôde ser reproduzida. As diferenças obtidas por ocasião da etapa de validação se mostraram aceitáveis, face às simplificações impostas aos algoritmos e à variabilidade intrínseca ao ambiente agrícola.

- A aplicação de conceitos logísticos no planejamento da operação de colheita mostrouse útil, sendo assim um recurso em potencial de redução de seus custos e melhoria da qualidade de realização de suas atividades.

- Os componentes fixos apresentam maior participação na formação do custo final da tonelada colhida do que os variáveis. Isso faz com que a premissa de um compromisso maior entre valor de aquisição e capacidade de trabalho seja reforçada. A aquisição de máquinas de elevado valor se justifica apenas caso essas tragam consigo incrementos compensatórios de capacidade potencial.

- A distribuição do custo final de retirada da tonelada entre a colheita, o transbordo e o transporte é função do total de produção a ser colhido, do posicionamento dos veículos e da locação dos talhões. À medida que a colheita de maiores produções é agendada, e que as distâncias a serem percorridas pelas carretas de transbordo e pelos veículos são maiores, os custos desses assumem maior participação na composição de custo.

- O fator de maior contribuição ao aporte de capital é o valor com o qual as colhedoras são adquiridas. A depreciação é o componente de maior participação, seguida da taxa de juros, das taxas de reparo e manutenção e do combustível.

- A capacidade potencial da frota de colhedoras é o parâmetro onde residem os maiores 
potenciais de redução de custo. Além de reduzir os custos da colheita propriamente dita, a capacidade de retirada dessas rege o desempenho das carretas de transbordo e dos veículos de transporte, o que demonstra um comportamento sistêmico entre esses três componentes da maquinaria.

- Na colheita, a capacidade efetiva da frota e o nível de eficiência da operação são as variáveis cujo incremento deve ser o foco da otimização e do planejamento. No transbordo e no transporte, são destacáveis os ganhos potenciais de uma melhor coordenação nas atividades de carga e descarga de carretas e veículos.

- No transbordo e no transporte, os sistemas caracterizados por rotas de curtas distâncias são altamente penalizados com aumentos no tempo de carga e descarga. Uma vez que esses são regidos pela taxa de retirada da frota de colhedoras, quanto maior essa o for, menor o tempo de espera de carretas e veículos, e melhor o desempenho do sistema. As rotas longas não sofrem um impacto grande, visto que o seu custo é diluído em um tempo de viagem proporcionalmente maior.

- A capacidade de carga útil dos veículos apresenta fortes economias de escala e, sob o ponto de vista estrito do transporte, há razões econômicas em utilizar veículos de maior capacidade na movimentação da produção, especialmente em sistemas nos quais os talhões se encontram locados em longas distâncias.

- Quanto ao planejamento, a reformulação da frota, a fim de elevar a sua capacidade, e a adoção de medidas que permitam o incremento do desempenho da maquinaria são estratégias viáveis em sistemas que requerem elevadas taxas de retirada e/ou quando a capacidade de recebimento das unidades de recepção permitir a retirada da produção em um curto intervalo de tempo.

- Em sistemas de colheita que não utilizam transbordos, a taxa de incremento de custo frente a alterações de distância é mais acentuada do que nos sistemas que os utilizam. O sistema de menor custo é aquele no qual não são utilizadas carretas graneleiras e os veículos se posicionam de forma estratégica em relação às colhedoras, a fim de evitar deslocamentos excessivos por parte dessas ultimas. 
ANEXOS 
ANEXO A

SisColhe - Programa de Instalação. 


\section{ANEXO B}

\section{Colhedoras - Registros de Validação do Desempenho Operacional}

Eventos: Colheita, Deslocamento e Descarregamento

\begin{tabular}{|c|c|c|c|}
\hline \multirow{2}{*}{$\begin{array}{c}\text { Tomada de } \\
\text { Tempo }\end{array}$} & \multicolumn{3}{|c|}{ Tempo de duração dos eventos (min) } \\
\hline & Colheita & Deslocamento & Descarregamento \\
\hline 1 & 19,50 & 2,50 & 2,25 \\
\hline 2 & 20,00 & 5,00 & 2,3 \\
\hline 3 & 27,75 & 2,15 & 2,25 \\
\hline 4 & 21,00 & 2,00 & 2,25 \\
\hline 5 & 20,00 & 0,50 & 2,25 \\
\hline 6 & 25,50 & 1,75 & 2 \\
\hline 7 & 21,25 & 3,00 & 2 \\
\hline 8 & 19,75 & 1,00 & 2,5 \\
\hline 9 & 20,75 & 1,75 & 2 \\
\hline 10 & 24,00 & 4,00 & 1,75 \\
\hline 11 & 24,00 & 6,75 & 1,3 \\
\hline 12 & 20,25 & 4,00 & 2,5 \\
\hline 13 & 24,25 & 2,75 & 1,75 \\
\hline 14 & 24,00 & 2,25 & 2 \\
\hline 15 & 24,75 & 0,75 & 1,75 \\
\hline 16 & 27,25 & 2,50 & 2 \\
\hline 17 & 26,75 & 2,50 & 1,75 \\
\hline
\end{tabular}


Veículos - Registros de Validação do Desempenho Operacional

Eventos: Carregamento e Descarregamento

\begin{tabular}{|c|c|c|c|c|}
\hline \multirow{2}{*}{$\begin{array}{c}\text { Tomada de } \\
\text { Tempo }\end{array}$} & \multicolumn{2}{|c|}{ Carregamento } & \multicolumn{2}{|c|}{ Descarregamento } \\
\hline & Hora Inicial & Hora Final & Hora Inicial & Hora Final \\
\hline 1 & $8: 51$ & $8: 53$ & 9:04 & 9:07 \\
\hline 2 & 9:11 & 9:13 & 9:16 & $9: 18$ \\
\hline 3 & $9: 31$ & $9: 33$ & $9: 41$ & $9: 47$ \\
\hline 4 & $9: 50$ & $9: 52$ & 9:57 & 10:01 \\
\hline 5 & $10: 04$ & $10: 06$ & $10: 09$ & $10: 17$ \\
\hline 6 & $10: 24$ & $10: 26$ & $10: 29$ & $10: 34$ \\
\hline 7 & $10: 54$ & $10: 56$ & 11:07 & $11: 12$ \\
\hline 8 & $11: 14$ & $11: 16$ & $11: 19$ & $11: 23$ \\
\hline 9 & 11:31 & $11: 33$ & $11: 36$ & $11: 40$ \\
\hline 10 & $12: 44$ & $12: 51$ & $12: 55$ & $12: 59$ \\
\hline 11 & 13:04 & $13: 06$ & $13: 14$ & $13: 18$ \\
\hline 12 & $13: 22$ & $13: 25$ & $13: 33$ & $13: 37$ \\
\hline 13 & $13: 56$ & $13: 58$ & 14:05 & $14: 10$ \\
\hline 14 & $14: 33$ & $14: 35$ & $14: 40$ & $14: 46$ \\
\hline 15 & $15: 33$ & $15: 35$ & $15: 39$ & $15: 44$ \\
\hline 16 & $15: 51$ & $15: 53$ & $16: 00$ & $16: 05$ \\
\hline 17 & $16: 44$ & $16: 46$ & $16: 58$ & $17: 02$ \\
\hline
\end{tabular}


Veículos - Registros de Validação do Desempenho Operacional

Evento: Viagem de Ida

\begin{tabular}{cccccc}
\hline $\begin{array}{c}\text { Tomada de } \\
\text { Tempo }\end{array}$ & Hora Inicial & Hora Final & Duração & $\begin{array}{c}\text { Percurso } \\
(\mathrm{km})\end{array}$ & $\begin{array}{c}\text { Veloc. Média } \\
(\mathrm{km} / \mathrm{h})\end{array}$ \\
\hline 1 & $11: 40$ & $11: 53$ & $0: 13$ & 8,00 & 37,00 \\
2 & $13: 16$ & $13: 22$ & $0: 06$ & 7,00 & 70,00 \\
3 & $14: 07$ & $14: 20$ & $0: 13$ & 9,00 & 42,00 \\
4 & $14: 56$ & $15: 09$ & $0: 13$ & 9,00 & 42,00 \\
5 & $16: 08$ & $16: 23$ & $0: 15$ & 8,00 & 32,00 \\
6 & $11: 27$ & $11: 37$ & $0: 10$ & 8,00 & 48,00 \\
7 & $12: 24$ & $12: 35$ & $0: 11$ & 9,00 & 49,00 \\
8 & $14: 20$ & $14: 30$ & $0: 10$ & 9,00 & 54,00 \\
9 & $17: 32$ & $17: 41$ & $0: 09$ & 9,00 & 60,00 \\
10 & $11: 18$ & $11: 28$ & $0: 10$ & 8,00 & 48,00 \\
\hline
\end{tabular}


Veículos - Registros de Validação do Desempenho Operacional

Evento: Viagem de Volta

\begin{tabular}{cccccc}
\hline $\begin{array}{c}\text { Tomada de } \\
\text { Tempo }\end{array}$ & Hora Inicial & Hora Final & Duração & $\begin{array}{c}\text { Percurso } \\
(\mathrm{km})\end{array}$ & $\begin{array}{c}\text { Veloc. Média } \\
(\mathrm{km} / \mathrm{h})\end{array}$ \\
\hline 1 & $11: 12$ & $11: 31$ & $0: 19$ & 8,00 & 25,00 \\
2 & $12: 45$ & $13: 02$ & $0: 17$ & 10,00 & 35,00 \\
3 & $13: 42$ & $13: 58$ & $0: 16$ & 9,00 & 34,00 \\
4 & $14: 35$ & $14: 50$ & $0: 15$ & 9,00 & 34,00 \\
5 & $15: 43$ & $16: 00$ & $0: 17$ & 8,00 & 28,00 \\
6 & $11: 02$ & $11: 15$ & $0: 13$ & 8,00 & 37,00 \\
7 & $12: 00$ & $12: 16$ & $0: 16$ & 9,00 & 34,00 \\
8 & $13: 55$ & $14: 12$ & $0: 17$ & 9,00 & 32,00 \\
9 & $15: 27$ & $15: 39$ & $0: 12$ & 8,00 & 40,00 \\
10 & $17: 03$ & $17: 20$ & $0: 17$ & 9,00 & 32,00 \\
11 & $10: 58$ & $11: 07$ & $0: 09$ & 4,00 & 26,00 \\
12 & $14: 28$ & $14: 44$ & $0: 16$ & 11,00 & 41,00 \\
13 & $10: 54$ & $11: 04$ & $0: 10$ & 8,00 & 48,00 \\
14 & $11: 56$ & $12: 14$ & $0: 18$ & 8,00 & 26,00 \\
15 & $13: 27$ & $13: 42$ & $0: 15$ & 8,00 & 32,00 \\
16 & $14: 30$ & $14: 43$ & $0: 13$ & 8,00 & 37,00 \\
17 & $15: 25$ & $15: 38$ & $0: 13$ & 8,00 & 37,00 \\
\hline & & & & & \\
\hline
\end{tabular}




\section{ANEXO C}

\section{Caracterização dos Cenários Base - Maquinaria.}

\section{COLHEITA}

\section{Colhedora:}

- Marca: JOHN DEERE;

- Modelo: 1550;

- Potência nominal (kW): 167,8;

- Capacidade do graneleiro (L): 6000;

- Vazão do tubo de descarga (L.s $\left.{ }^{-1}\right):$ 65;

- Valor de aquisição (R\$): 345.666.

\section{Plataforma:}

- Marca: JOHN DEERE;

- Modelo: 323 MASTER;

- Tipo: corte;

- Largura nominal (m): 6,8;

- Valor de aquisição (R\$): 49.182.

\section{Caracterízação da operação:}

- Velocidade de colheita (km.h $\left.{ }^{-1}\right): 8,0$;

- Eficiência de operação 9\%): 85,0; 
- Eficiência de gerência (\%): 85,0.

\section{TRANSBORDO}

Trator:

- Marca: JOHN DEERE;

- Modelo: 6600;

- Tração: 4x2 TDA;

- Potência nominal (kW): 90,0;

- Valor de aquisição (R\$): 144.000,00.

\section{Carreta Graneleira:}

- Marca: STARA;

- Modelo: REBOKE 9000;

- Capacidade do graneleiro (L): 9230;

- Vazão do tubo de descarga (L.s ${ }^{-1}$ ): 30;

- Valor de aquisição (R\$): 21.000.

\section{Caracterízação da operação:}

- Velocidade viagem de ida $\left(\mathrm{km} \cdot \mathrm{h}^{-1}\right): 12,0$;

- Velocidade viagem de volta $\left(\mathrm{km} \cdot \mathrm{h}^{-1}\right): 8,0$;

- Eficiência de gerência (\%): 85,0;

- Tempo auxiliar por ciclo (min): 2,5;

- Tempo perdido por ciclo (min): 2,5.

\section{TRANSPORTE}

Veículo:

- Marca: MERCEDES-BENZ;

- Modelo: MB 1622; 
- Característica: Truck;

- Peso líquido (t): 9,7;

- Peso bruto (t): 26,7;

- Potência nominal (kW): 163,0;

- Valor de aquisição (R\$): 95.000;

- Número de pneus: 10;

- Vida útil pneu (km): 47000;

- Valor de aquisição pneus (R\$.unidade ${ }^{-1}$ ): 750.

\section{Caracterízação da operação:}

- Velocidade viagem de ida $\left(\mathrm{km}_{\mathrm{h}} \mathrm{h}^{-1}\right)$ : 50,0;

- Velocidade viagem de volta $\left(\mathrm{km} . \mathrm{h}^{-1}\right)$ : 35,0;

- Eficiência de gerência (\%): 85,0;

- Consumo viagem de ida $\left(\mathrm{km} . \mathrm{L}^{-1}\right)$ : 3,6;

- Consumo viagem de volta $\left(\mathrm{km} . \mathrm{L}^{-1}\right): 2,15$;

- Tempo auxiliar por ciclo (min): 5,0;

- Tempo descarregamento por ciclo (min): 10,0;

- Tempo perdido por ciclo (min): 35,0. 


\section{ANEXO D}

\section{Caracterização dos Cenários Base - Talhões.}

Tabela 25. Detalhamento dos talhões utilizados, cenário base A.

\begin{tabular}{cccccc}
\hline Nome & $\begin{array}{c}\text { Área } \\
(\mathrm{ha})\end{array}$ & $\begin{array}{c}\text { Produt. } \\
\left(\mathrm{t} . h a^{-1}\right)\end{array}$ & $\begin{array}{c}\text { Produção } \\
(\mathrm{t})\end{array}$ & $\begin{array}{c}\text { Índice de } \\
\text { eficiência }\end{array}$ & $\begin{array}{c}\text { Rota } \\
(\mathrm{km})\end{array}$ \\
\hline Talhão 01 & 73,7 & 3,5 & 257,8 & 1,10 & 1,8 \\
Talhão 02 & 64,0 & 3,5 & 224,0 & 1,08 & 1,8 \\
Talhão 03 & 42,7 & 3,5 & 149,3 & 1,03 & 1,8 \\
Talhão 04 & 40,3 & 3,5 & 141,2 & 0,82 & 2,0 \\
Talhão 05 & 54,7 & 3,5 & 191,3 & 1,03 & 2,3 \\
Talhão 06 & 36,0 & 3,5 & 126,0 & 0,82 & 1,7 \\
Talhão 07 & 38,3 & 3,5 & 134,2 & 0,95 & 2,0 \\
Talhão 08 & 39,0 & 3,5 & 136,5 & 0,90 & 2,3 \\
Talhão 09 & 58,3 & 3,5 & 204,2 & 0,78 & 4,3 \\
Talhão 10 & 42,7 & 3,5 & 149,3 & 0,95 & 3,6 \\
Talhão 11 & 37,3 & 3,5 & 130,7 & 0,95 & 1,9 \\
Talhão 12 & 32,0 & 3,5 & 112,0 & 1,03 & 2,5 \\
Talhão 13 & 42,7 & 3,5 & 149,3 & 0,96 & 1,7 \\
Talhão 14 & 29,7 & 3,5 & 103,8 & 1,00 & 0,9 \\
Talhão 15 & 54,0 & 3,5 & 189,0 & 0,95 & 0,8 \\
Talhão 16 & 26,7 & 3,5 & 93,3 & 1,03 & 3,0 \\
\hline
\end{tabular}


Tabela 26. Detalhamento dos talhões utilizados, cenário base B.

\begin{tabular}{cccccc}
\hline Nome & $\begin{array}{c}\text { Área } \\
(\mathrm{ha})\end{array}$ & $\begin{array}{c}\text { Produt. } \\
\left(\text { t.ha }^{-1}\right)\end{array}$ & $\begin{array}{c}\text { Produção } \\
(\mathrm{t})\end{array}$ & $\begin{array}{c}\text { Índice de } \\
\text { eficiência }\end{array}$ & $\begin{array}{c}\text { Rota } \\
(\mathrm{km})\end{array}$ \\
\hline Talhão 01 & 221,0 & 3,5 & 773,5 & 1,10 & 5,4 \\
Talhão 02 & 192,0 & 3,5 & 672,0 & 1,08 & 5,4 \\
Talhão 03 & 128,0 & 3,5 & 448,0 & 1,03 & 5,3 \\
Talhão 04 & 121,0 & 3,5 & 423,5 & 0,82 & 6,0 \\
Talhão 05 & 164,0 & 3,5 & 574,0 & 1,03 & 6,8 \\
Talhão 06 & 108,0 & 3,5 & 378,0 & 0,82 & 5,0 \\
Talhão 07 & 115,0 & 3,5 & 402,5 & 0,95 & 6,1 \\
Talhão 08 & 117,0 & 3,5 & 409,5 & 0,90 & 6,9 \\
Talhão 09 & 175,0 & 3,5 & 612,5 & 0,78 & 13,0 \\
Talhão 10 & 128,0 & 3,5 & 448,0 & 0,95 & 10,8 \\
Talhão 11 & 112,0 & 3,5 & 392,0 & 0,95 & 5,7 \\
Talhão 12 & 96,0 & 3,5 & 336,0 & 1,03 & 7,6 \\
Talhão 13 & 128,0 & 3,5 & 448,0 & 0,96 & 5,1 \\
Talhão 14 & 89,0 & 3,5 & 311,5 & 1,00 & 2,6 \\
Talhão 15 & 162,0 & 3,5 & 567,0 & 0,95 & 2,4 \\
Talhão 16 & 80,0 & 3,5 & 280,0 & 1,03 & 8,9 \\
\hline
\end{tabular}


Tabela 27. Detalhamento dos talhões utilizados, cenário base C.

\begin{tabular}{cccccc}
\hline Nome & $\begin{array}{c}\text { Área } \\
(\mathrm{ha})\end{array}$ & $\begin{array}{c}\text { Produt. } \\
\left(\mathrm{t}^{-1} \mathrm{C}^{-1}\right)\end{array}$ & $\begin{array}{c}\text { Produção } \\
(\mathrm{t})\end{array}$ & $\begin{array}{c}\text { Índice de } \\
\text { eficiência }\end{array}$ & $\begin{array}{c}\text { Rota } \\
(\mathrm{km})\end{array}$ \\
\hline Talhão 01 & 1105,0 & 3,5 & 3867,5 & 1,10 & 26,9 \\
Talhão 02 & 960,0 & 3,5 & 3360,0 & 1,08 & 26,9 \\
Talhão 03 & 640,0 & 3,5 & 2240,0 & 1,03 & 26,7 \\
Talhão 04 & 605,0 & 3,5 & 2117,5 & 0,82 & 30,1 \\
Talhão 05 & 820,0 & 3,5 & 2870,0 & 1,03 & 34,0 \\
Talhão 06 & 540,0 & 3,5 & 1890,0 & 0,82 & 25,1 \\
Talhão 07 & 575,0 & 3,5 & 2012,5 & 0,95 & 30,5 \\
Talhão 08 & 585,0 & 3,5 & 2047,5 & 0,90 & 34,4 \\
Talhão 09 & 875,0 & 3,5 & 3062,5 & 0,78 & 65,0 \\
Talhão 10 & 640,0 & 3,5 & 2240,0 & 0,95 & 54,1 \\
Talhão 11 & 560,0 & 3,5 & 1960,0 & 0,95 & 28,7 \\
Talhão 12 & 480,0 & 3,5 & 1680,0 & 1,03 & 38,0 \\
Talhão 13 & 640,0 & 3,5 & 2240,0 & 0,96 & 25,3 \\
Talhão 14 & 445,0 & 3,5 & 1557,5 & 1,00 & 13,0 \\
Talhão 15 & 810,0 & 3,5 & 2835,0 & 0,95 & 12,2 \\
Talhão 16 & 400,0 & 3,5 & 1400,0 & 1,03 & 44,5 \\
\hline
\end{tabular}




\section{ANEXO E}

Maquinaria - componentes de custo. Cenários base A, B e C.

\section{Colhedoras:}

- Vida útil (h): 5000;

- Valor de revenda (\%): 25;

- Alojamento, seguros e taxas (\%): 1,2;

- Taxa de reparo e manutenção (\%): 40;

- Custo dos operadores (R\$. $\left.\mathrm{h}^{-1}\right): 5,7$.

\section{Tratores:}

- Vida útil (h): 10000;

- Valor de revenda (\%): 25;

- Alojamento, seguros e taxas (\%): 1,2;

- Taxa de reparo e manutenção (\%): 80;

- Custo dos operadores (R\$.h $\left.\mathrm{h}^{-1}\right): 5,7$.

\section{Carretas Graneleiras:}

- Vida útil (h): 2500;

- Valor de revenda (\%): 25;

- Alojamento, seguros e taxas (\%): 1,2;

- Taxa de reparo e manutenção (\%): 40; 


\section{Veículos:}

- Vida útil (km): 1.000.000;

- Valor de revenda (\%): 46;

- Alojamento, seguros e taxas (\%): 5,5;

- Índice de manutenção* (\% a.m.): 1,35;

- Índice de lubrificante ${ }^{* *}(\%): 2,8$.

\section{Mercado:}

- Taxa de juros $^{* * *}$ (\% a.a.): 11,75;

- Valor do combustível (R\$.L $\left.{ }^{-1}\right): 1,27$.

\footnotetext{
* \% do valor de aquisição desprendido ao mês com custos de reparos e manutenção.

** \% do custo de combustível.

${ }^{* * *}$ Taxa de juros anual sobre o capital investido.
} 


\section{ANEXO F}

Maquinaria - reformulação da frota.

\section{Colhedora:}

- Marca: JOHN DEERE;

- Modelo: 9650 STS;

- Potência nominal (kW): 217,0;

- Capacidade do graneleiro (L): 8850;

- Vazão do tubo de descarga (L.s $\left.{ }^{-1}\right): 78$;

- Valor de aquisição (R\$): 505.000.

\section{Plataforma:}

- Marca: JOHN DEERE;

- Modelo: 630 F;

- Tipo: corte;

- Largura nominal (m): 9,1;

- Valor de aquisição (R\$): 71.000.

\section{Trator:}

- Marca: JOHN DEERE;

- Modelo: 6600;

- Tração: 4x2 TDA;

- Potência nominal (kW): 90,0; 
- Valor de aquisição (R\$): 144.000,00.

\section{Carreta Graneleira:}

- Marca: FANKHAUSER;

- Modelo: 8070;

- Capacidade do graneleiro (L): 17600;

- Vazão do tubo de descarga (L.s $\left.{ }^{-1}\right): 59$;

- Valor de aquisição (R\$): 27.000.

\section{Veículo:}

- Marca: VOLVO;

- Modelo: NL 10 340;

- Característica: Carreta;

- Peso líquido (t): 27,0;

- Peso bruto (t): 54,0;

- Potência nominal (kW): 254,0;

- Valor de aquisição (R\$): 117.000;

- Número de pneus: 18;

- Vida útil pneu (km): 117.000;

- Valor de aquisição pneus (R\$.unidade ${ }^{-1}$ ): 820. 


\section{REFERÊNCIAS BIBLIOGRÁFICAS}

ABAYNAYAKA, S.W.; HIDE, H.; MOROSIUK, G.; ROBINSON, R. Tables for estimating vehicle operating costs on rural roads in developing countries. Crowthorne: Transport and Road Research Laboratory, 1976. 59p. (Laboratory Report, 723).

AL-SOBOH, G.; SRIVASTAVA, A.K.; BURKHARDT, T.H.; KELLY, J.D. A mixedinteger linear programming (MILP) machinery selection model for navybean production systems. Transactions of the ASAE, v.29, n.1, p.81-89, 1986.

ALVARENGA, A.C.; NOVAES, A.G. Logística aplicada: suprimento e distribuição física. São Paulo: Edgar Blücher, 1999. 194p.

ALVES, E.S. Sistemas logísticos integrados: um quadro de referência. Florianópolis, 2000. 109p. Dissertação (Mestrado) - Universidade Federal de Santa Catarina.

AMERICAN SOCIETY OF AGRICULTURAL ENGINEERING. ASAE standards. St. Joseph, 1999a. p.353-358: Agricultural machinery management ASAE EP496.2.

AMERICAN SOCIETY OF AGRICULTURAL ENGINEERING. ASAE standards. St. Joseph, 1999b. p.359-366: Agricultural machinery management Data ASAE D497.4.

BALASTREIRE, L.A. Máquinas agrícolas. São Paulo: Manole, 1987. 309p.

BALLOU, R.H. Logística empresarial. São Paulo: Atlas, 1993. 388 p. 
BALLOU, R.H. Gerenciamento da cadeia de suprimentos: planejamento, organização e logística empresarial. Porto Alegre: Bookman, 2001. 532 p.

BANIER, R.; KEPNER, R.A.; BARGER, E.L. Principles of farm machinery. New York: John Wiley, 1955. 571 p.

BARBOSA, M.M.; MILAN, M.; COELHO, J.L.D. Planning of an agricultural machinery system. In: INTERNATIONAL CONFERENCE ON COMPUTERS IN AGRICULTURE, Orlando, 1998. Proceedings. Orlando: ASAE, 1998. p.35-40.

BATAVO. Castro, n.26, ago. 2003. 50p.

BOWERSOX, D.J.; CLOSS, J.R. Logistical management. 3.ed. New York: McGrawHill, 1996. 730 p.

BOWERSOX, D.J.; CLOSS, J.R. Logística empresarial: o processo de integração da cadeia de suprimento. São Paulo: Atlas, 2001. 594 p.

BRASIL. Ministério da Agricultura, Pecuária e Abastecimento. http://www.agricultura. gov.br. (10 mai. 2004).

BURROWS, W.C.; SIEMENS, J.C. Determination of optimum machinery for cornsoybean farms. Transactions of the ASAE, v.17, n.12, p.1130-1135, 1974.

CAIXETA FILHO, J.V. Pesquisa operacional: técnicas de otimização aplicadas a sistemas agroindustriais. São Paulo: Atlas, 2001. 171 p.

CHEN, L.H.; AHMAD, T.; WILLCUTT, M.H. Simulation model for cotton harvesting machinery. Transactions of the ASAE, v.35, n.3, p.1071-1077, 1992.

CHRISTOPHER, M. Logística e gerenciamento da cadeira de suprimentos. São Paulo: Pioneira, 1997. 240 p. 
COKINS, G. Activity-based cost management: making it work: a manager's guide to implementing and sustaining an effective ABC system. Chicago: Irwin Professional Publishing, 1996. 226 p.

COLLI, P. Um modelo de avaliação de desempenho da distribuição física. Florianópolis, 2001. 129 p. Dissertação (Mestrado) - Universidade Federal de Santa Catarina.

COLVIN, S.T.; McCONNELL, K.L.; CATUS, B.J. “TERMS”: a computer model for field simulation. Transactions of the ASAE, v.32, n. 2, p.391-396, 1989.

CONFEDERAÇÃO NACIONAL DE TRANSPORTE. http://notesweb.cnt.org.br/aplic/ caminhoneiro.nsf/truck?OpenForm. (19 set. 2003).

COORDENADORIA DE ASSISTÊNCIA TÉCNICA INTEGRAL. Produção de milho: racionalização das práticas culturais de colheita e de armazenamento. São Paulo, 1973. 39 p.

DAHAB, M.H.; O’CALLAGHAM, J.R. Simulation modeling for crop-disease spraying management. Agricultural Mechanization in Asia, Africa and Latin America, v.29, n.3, p.27-32, 1998

EDWARDS, W.; BOEJLHE, M. Machinery selection considering timeliness losses. Transactions of the ASAE, v.23, n.4, p.810-815, 1980.

FEY, E.; CATARINA, A.S.; SANTOS, S.R.; PEREIRA, J.O. Planejamento de um sistema agrícola utilizando programação linear: estudo de caso. Revista Engenharia Agrícola, v.22, n.3, p.368-377, 2002.

FLEURY, P.F. A logística brasileira em perspectiva. In: FLEURY, P.F.; WANKE, P.; FIGUEIREDO, K.F. Logística empresarial: a perspectiva brasileira. São Paulo: Atlas, 2000. cap.1, p.19-27.

FLEURY, P.F.; WANKE, P.; FIGUEIREDO, K.F. Logística empresarial: a perspectiva brasileira. São Paulo: Atlas, 2000. 372 p. 
FNP CONSULTORIA \& COMÉRCIO. Agrianual 2003: anuário estatístico da agricultura brasileira. São Paulo, 2003. 544p.

FNP CONSULTORIA \& COMÉRCIO. Agrianual 2004: anuário estatístico da agricultura brasileira. São Paulo, 2004. 496p.

FROTA \& CIA. São Paulo, n.26, ago. 1999. 50p.

GIMENEZ, L.M.; KATSMAN, T.; MOLIN, J.P. Determinação da capacidade efetiva de colheita e analise econômica em talhões com a utilização de informações do monitoramento do rendimento. In: BALASTREIRE, L.A. Avanços na Agricultura de Precisão no Brasil no período 1999-2001. Piracicaba: O autor, 2002. p.164.

GLANZE, P. Technical fundamentals of grain maize in tropical and subtropical regions. Berlin: Leipzig, 1972. 196p.

GRIFFIN, G.A. Combine harvesting: operating maintaining and improving efficiency of combines. 4.ed. Chicago: John Deere \& Company/Malone, 1991. 207p.

GRISSO, R.D.; JASA, P.J.; ROLOFSON, D.E. Analysis of traffic patterns and yield monitor data for field efficiency determination. Transactions of the ASAE, v.18, n.2, p.171-178, 2002.

HAFFAR, I.; VAN EE, G. "CHUCHARV”: a simulation model for optimizing mechanical harvesting returns of pickling cucumbers. Transactions of the ASAE, v.35, n.1, p.45-50, 1992.

HANSEN, A.C.; BARNES, A.J.; LYNE, P.W.L. Simulation modeling of sugarcane harvest-to-mill delivery systems. Transactions of the ASAE, v.45, n.3, p.531-538, 2002.

HUAN-WEN, G.; HUNT, D.R. Optimum combine fleet selection with power-based models. Transactions of the ASAE, v.28, n.2, p.364-368, 1985. 
HUGHES, H.A.; HOLTMAN, J.B. Machinery complement selection based on time constraints. Transactions of the ASAE, v.19, n.5, p. 812-814, 1976.

HUNT, D.R. Farm power and machinery management. 9.ed. Ames: Iowa University Press, 1977. 365p.

INOVAÇÃO E MELHORAMENTO NA ADMINISTRAÇÃO MODERNA. Gerenciamento da logística e cadeia de abastecimento. São Paulo, 2000. 281 p.

KEPNER, R.A.; BAINER, R.; BARGER, E.L. Principles of farm machinery. 2.ed. Westport: AVI Publishing, 1972. 486p.

LAL, H.; PEART, R.M.; JONES, J.W.; SHOUP, W.D. FARMSYS: a whole-farm machinery management decision system. Agricultural Systems, v.38, p.257-273, 1992.

LAMBERT, D.M.; STOCK, J.R. Strategic logistics management. 3.ed. Boston: Irwin, 1992. $862 \mathrm{p}$.

LAMBERT, D.M.; STOCK, J.R.; ELLRAM, L.M. Fundamentals of logistics management. Singapore: Irwin/McGraw-Hill, 1998. 611 p.

LINK, D. Activity network techniques applied to a farm machinery selection problem. Transactions of the ASAE, v.10, n.3, p. 310-317, 1967.

LOPES, M. B.; MILAN, M. Simulation of a sugar cane loading and transport system. In: INTERNATIONAL CONFERENCE ON COMPUTERS IN AGRICULTURE, Orlando, 1998. Proceedings. Orlando: ASAE, 1998. p.124-130.

MARTINS, E. Contabilidade de custos. 5.ed. São Paulo: Atlas, 1996. 381p.

MIALHE, L.G. Manual de mecanização agrícola. São Paulo: Agronômica Ceres, 1974. $301 \mathrm{p}$.

MIALHE, L.G. Máquinas para colheita de cereais. Piracicaba: ESALQ, 1984. 66 p. 
MILAN, M. Improving operational management of harvest, transport and mechanization for sugar-cane in Brazil. Silsoe, 1992. 226p. Ph.D. (Thesis) - Silsoe College, Cranfield Institute of Technology.

MOLIN, J.P.; MILAN, M. Effect of globalization on the agricultural machinery industry in Brazil. Agricultural Mechanization in Asia, Africa and Latin America, v.32, n.3, p.67-72, 2001.

MORAIS, M.F.S. Custeio baseado em atividades para o desenvolvimento de software na Prodabel. Belo Horizonte, 2003. 52p. Monografia (Especialização) - Pontifica Universidade Católica de Minas Gerais.

NAKAGAWA, M. Gestão estratégica de custos: conceito, sistemas e implementação JIT/TQC. São Paulo: Atlas, 1991. 111p.

NAKAGAWA, M. Abc: custeio baseado em atividades. São Paulo: Atlas, 1994. 95p.

NESSRALLAH, M.G.T.; MOLIN, J.P. Metodologia para o cálculo da eficiência de campo na operação de colheita. In: SIMPÓSIO INTERNACIONAL DE INICIAÇÃO CIENTÍFICA DA UNIVERSIDADE DE SÃO PAULO, 9., Piracicaba, 2001. Resumos. São Paulo: USP, 2001. p.73.

NOVAES, A.G. Logística e gerenciamento da cadeia de distribuição. Rio de Janeiro: Campus, 2001. 410 p.

ORTÍZ-CAÑAVATE, J.P. Lãs máquinas agrícola y su aplicacion. Madrid: Ediciones Mundi-Prensa, 1993. 467 p.

ORTÚZAR, J.D.; WILLUMSEN, L.G. Modelling transport. 2. ed. New York: John Wiley, 1994. 440 p.

OSTRENGA, M.R.; OZAN, T.R.; McILHATTAN, R.D.; HARWOOD, M.C. Guia da Ernst \& Young para gestão total dos custos. 13.ed. Rio de Janeiro: Record, 1993. 349 p. 
OZKAN, H.E.; HOLMES, R.G. Determining machinery timeliness cost in corn planting using DRAINMOD. Transactions of the ASAE, v.33, n.3, p.718-724, 1990.

OZKAN, H.E.; EDWARDS, W.M. A farmer-oriented machinery comparison model. Transactions of the ASAE, v.29, n.3, p.672-677, 1986.

PARMAR, R.S.; McCLENDON, R.W.; POTTER, W.D. Farm machinery selection using simulation and genetic algorithms. Transactions of the ASAE, v.39, n.5, p. 1905-1909, 1996.

QUICK, G.; BUCHELE, W. The grain harvesters. St. Joseph: ASAE, 2000. 269 p.

RENOLL, E.S. Concept for predicting capacity of row-crop machines. Transactions of the ASAE, v.15, n.5, p.1028-1030, 1972.

RENOLL, E.S. Predicting machine field capacity for specific field and operating conditions. Transactions of the ASAE, v.24, n.1, p.45-47, 1981.

RICHEY, C.B.; JACOBSON, P.; HALL, C.W. Agricultural engineers handbook. New York: McGraw-Hill, 1961. 880 p.

RIDENOUR, H.E. Combines and combining. Columbus: Ohio Agricultural Education Curriculum Materials, 1981. 141 p.

ROCHA, L.S.; MÜHLEN, S.S. Sistema de custeio baseado em atividades para gerenciamento do custo de manutenção de equipamentos médico-assistênciais (compact disc). In: CONGRESSO LATINOAMERICANO DE INGENIERIA BIOMÉDICA, Habana, 2001. Anais. Habana: Sociedad Cubana de Bioingenieria, 2001.

ROTZ, C.A.; MUHTAR, H.A.; BLACK, R. A multiple crop machinery selection algorithm. Transactions of the ASAE, v.26, n.6, p.1644-1649, 1983. 
SANTOS, J.P.; MANTOVANI, E.C. Perdas de grãos na cultura do milho: précolheita, transporte e armazenamento. Sete Lagoas: EMBRAPA, 1997. 50p.

SCHMITT, H.B. Modelo de avaliação de desempenho de operadores logísticos atuantes no setor agrícola de cargas a granel. Florianópolis, 2002. 147p. Dissertação (Mestrado) - Universidade Federal de Santa Catarina.

SILVEIRA, G.M. As colhedoras. In: RIPOLI, T.C.C. Coletânea de artigos sobre mecanização e máquinas agrícolas. Piracicaba: ESALQ, 1987. v.3, p.16-17.

SINGH, D.; HOLTMAN, J.B. An heuristic agricultural field machinery selection algorithm for multicrop farms. Transactions of the ASAE, v.22, n.4, p.763-770, 1979.

SOGAARD, H.T.; SORENSEN, C.G. A model for optimal selection of machines sizes within the farm machinery system. In: INTERNATIONAL CONFERENCE ON COMPUTERS IN AGRICULTURE, Cancun, 1996. Anais. Cancun: ASAE, 1996. p. 588-596.

SRIVASTAVA, A.K.; GOERING, C.E.; ROHRBACH, R.P. Engineering principles of agricultural machines. St. Joseph: ASAE, 1993. 601 p.

STAPLETON, H.N.; BARNES, K.K. Data needs for agricultural systems analysis. Transactions of the ASAE, v.10, n.3, p.303-309, 1967.

TACHIBANA, A.; MILAN, M. Modelo para avaliação de sistemas mecanizados para aplicação de defensivos em culturas perenes. Revista Engenharia Agrícola, v.22, n.1, p.101-109, 2002.

TACHIBANA, A.; MILAN, M.; MOURAO FILHO, F.A.A. Modelo para avaliar um sistema mecanizado para a cultura do limão siciliano (Citrus limon, BURM.). Revista Engenharia Agrícola, v.18, n.3, p.34-43, 1999. 
VEIGA, C.M. Modelo empírico para a seleção de máquinas agrícolas na cultura da soja considerando a pontualidade na semeadura. Piracicaba, 2000. 75 p. Dissertação (Mestrado) - Escola Superior de Agricultura Luiz de Queiroz, Universidade de São Paulo.

VON BARGEN, K. A system approach to harvesting alfafa hay. Transactions of the ASAE, v.10, n.3, p.318-319, 1967.

VON BARGEN, K. Systems analysis in hay harvesting. Transactions of the ASAE, v.9, n.6, p.768-770, 1966.

VON BARGEN, K.; CUNNEY, M.B. Activity ratios for farm machinery operations analysis. Transactions of the ASAE, v.17, n.2, p.225-227, 1974.

WITNEY, B. Choosing and using farm machines. Harlow: Longman Scientific \& Technical, 1988. 411 p. 